$3 \%$

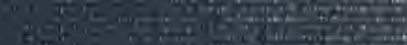

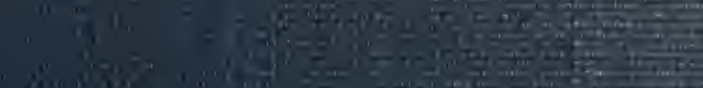

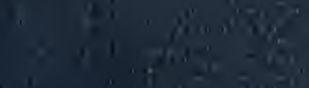
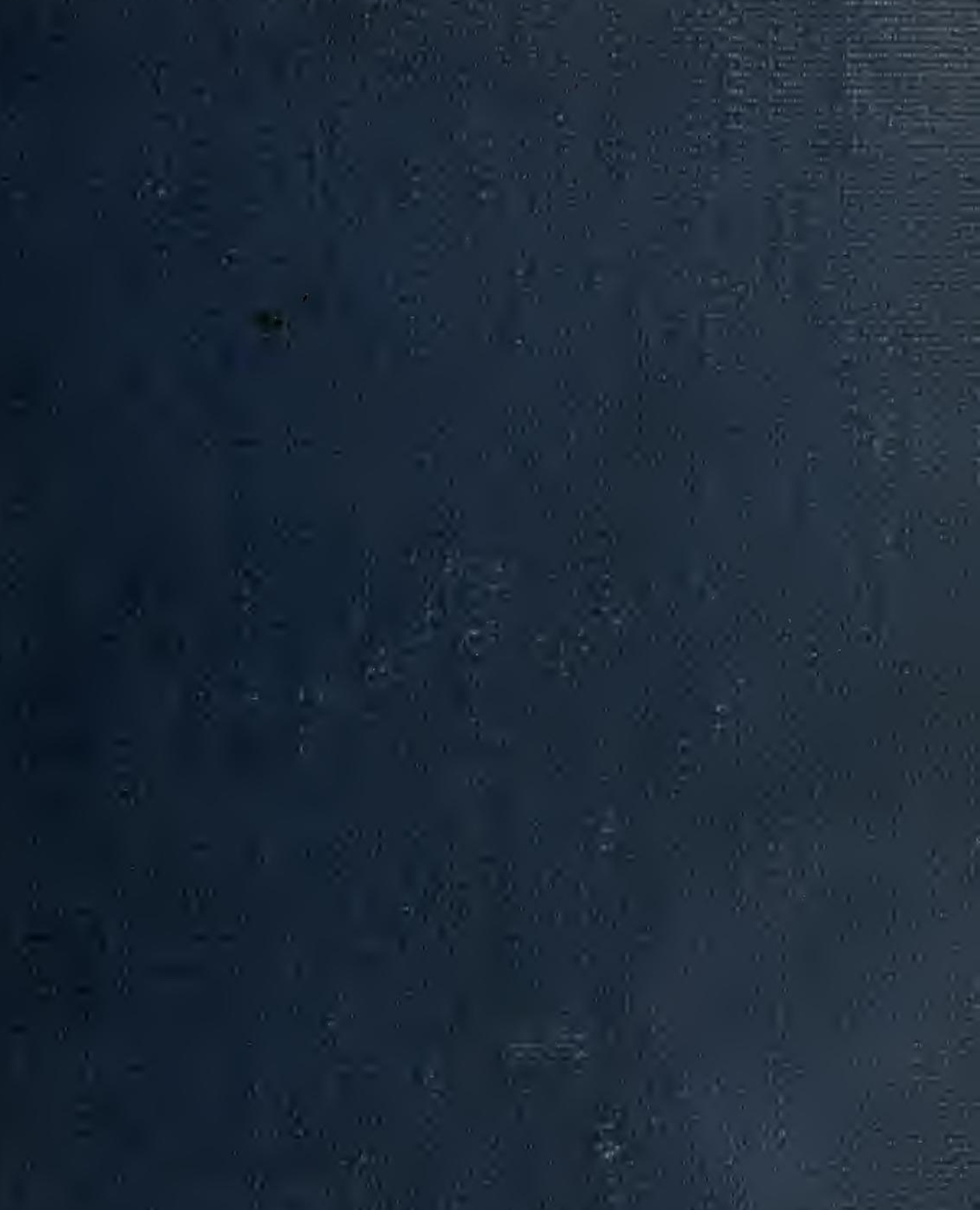

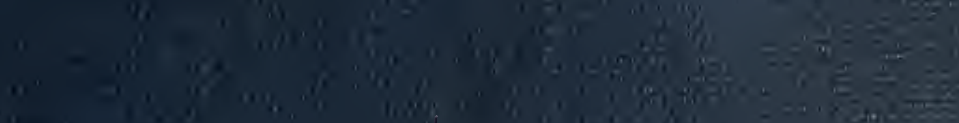


IVER RII

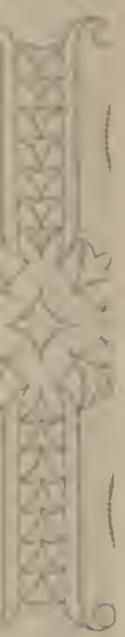
MIVERSIT

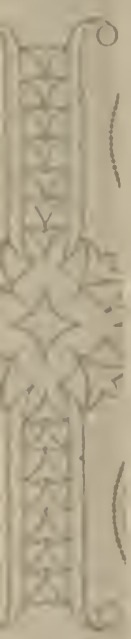

NIVERSIT

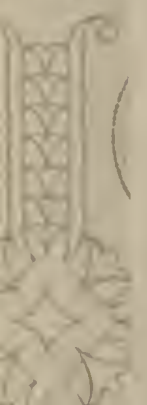


WORKS INSUED BY

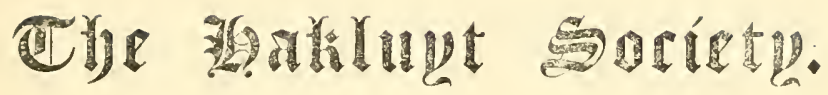

A COLLECTION OF DOCUMENTS ON

SPITZBERGEN AND GREENTAND. 
A (Olllection OF DOCUMENTS

$a \mathrm{~N}$

\section{SPITZBERGEN \& GREENLAND,}

(0MPRISIXU -1 TR.1N'I.ATIOX FR(I)

F. MARTENS' TOYAGE TO SPITZBERGEN:

A TRANSIATION FROM

ISAAC DE LA PEYRÈRE'S HISTOIRE DU GROENLAND :

AND

GOD'S POWER AND PROVIDENCE IN THE

PRESERVATION OF EIGHT MEN IN

GREENLAND NINE MONETHS

AND TWELVE DAYES.

E. IFL, IYY

A D A M WHITE, ESQ.,

OF TML: RRII ; IUSET

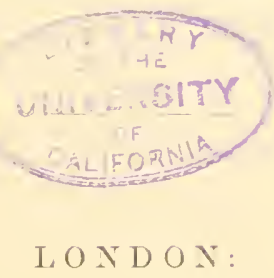

PRINTED FOR THE UAKLUYT SOCIETE. 



\section{'THE HAKLUY'T SOCIETY.}

SII: RODERICK IMPEY MURCHISON, G.C.St.S., F.R.S., Corn. Mtm. IHSt I.

Hon. Mem. Imp. Acad. Se. St. Petersburgh, \&c., de., Prestofent.

THE EARL OF ELLESMERE.

CAPT, C. I. DRINITHAER BETHUNF, R.N., C.B. $\}$ VICE-PKESIIESTS.

DAVTD BAILLIE, EsQ.

REAR*ADMIRAL Sir FRANCIS DEAUFORT, K.C.B., F.R.S.

RT. HON, LORD BROUGHTON.

WILLIAM DESBOROUGH COOLEY, ESQ.

ThE Right ReV. LORD BISIIOP OF ST. DAVID'S.

CHARLES WENTTORTH DILKE, EsQ., F.S.A.

RT. HON. SIR DAVID DUNDAS.

SIR HENRT ELLIS, K.H., F.R.S.

JOHN FORSTER, EsQ.

R. W. GREY, ESQ., MI.P.

JOHN WINTER JONES, EsQ., F.S.A.

His Excellency the COUNT de LAVRADic.

P. LEVESQUE, Esq., F.S.A.

THE EARL SOMERS.

Sir GEORGE STAUNTON, BART. D.C.L., F.R.S.

IV. STIRLING, Es\&., of Keir.

The REv. W. WHEWELL, D.D.

R. H. MAJOL, EsQ̨, F.S.A., Howorary SECRETARY 



\section{REPORT FOR 1855.}

Since the last Annual Mecting of the Hakluyt Societr, there has been little or no change in the number of its Nembers, or in the state of its Balance Sheet, to eall for special remark from the Council, in meeting the Members at the expiration of this, the eighth year of the Society's existence.

As regards the funds of the Society, it will be seen by the statement of accounts at the foot of this Report, that it continues to maintain a healthy and prosperous condition, with an adequate balance to meet the expenditure required for the average annual publications of the Society. 'That the number of Members should not have increased during the past year, is, perhaps, not to be wondered at. The list has been diminished by the death of several members; and the special character of the Society's publications, as alluded to in the last year's Report, may, in itself, be considered a fair reason why but few new members should have been added to it; while, at the same time, the number is sufficiently large to meet the current expense of publishing as many books as may fairly be considered a suitable return for each member's subscription. Another incidental cause may also have existed in the pressure of political events during the past year, calculated, as they have naturally been, not only to engross attention, but to restrict expenditure. A hindrance also has existed in the unwillingness expressed by new subscribers to pay so large a sum as the accumulated subscriptions for all the years of the Society's existence would amount to; although it is highly satisfactory to state, that on the very occasions when from the death of members, or otherwise, some of the Society's volumes have fallen into the hands of booksellers, they have been sold, even under these circumstances, at prices higher than the ordinary tcrms of subscription would cover. 'That such a difficulty as that referred to might not stand in the way of an object, which experience has shown to have such strong claims upon the attention of the literary world, it has been resolved by the Council to allow all new subscribers during the ensuing year to purchase complete sets of the Society's publications for the sum of Five Guineas, including the current year's subscription.

Meanwhile, the Council are happy to state that the main objects of the Society are being successfully carried out. 
During the past year the following books hare been issued to subscribers :

"The World Encompassed by Sir Francis Drake", 1577-80, written by Francis Fletcher, preacher, etc., collated with an unpubilished manuscript by the same writer, with appendices of various other elucidatory MSS. and printed documents, which together form a most interesting collection in illustration of the voyage in question. Edited by W. Sandys Vaux, Esq., M.A. 'The volume is accompanied by a copy of a most interesting cotemporancous and supposed unique map of the world in hemispheres, by Hondius, indicating the track of Drake and Candish. 'This valuable map, which was purchased by the British Muscum as unique, is especially remarkable for its extreme beauty, whon the date at which it was constructed is taken into consideration.

"The History of the Two Tartar Conquerors of China, including the two journeys into Tartary of Father Ferdinand Verbiest, in the suite of the Emperor Kang-Hi": from the French of Père Pierre Joseph D'Orleans, of the company of Jesus. With the addition of Father Pereira's Journey into 'Tartary in the suite of the same Emperor, from the Dutch of Nicolaas Witsen. 'Translated and Edited by the Earl of Ellesmere. With an Introduction by the Secretary of the Society.

Meanwhile, the following works are in progress:-

A Collection of Early Documents on Spitzbirgen AND Grexslasd, consisting of a translation from the German of F. Marten's important work on Spitzbergen, now very rarc. A translation from Isaac de la Peyrère's Relation de Groenland, first printed in $164 \%$, with a small tract on Grecnland, entitled, "God's Power and Providence shewed in the miraculous preservation and deliverance of eight Englishmen, left by mischance in Grecnland, anmo 1630, nine moneths and twelve days, faithfully reported by Edward Pelham." Edited, with Notes, by Adam White, Esq., of the British Museum.

A Collection of Emibassies to Russia ix the reigns of Qublex Elizabeth axd Kixg Janes I: comprising, "The Russe Commonwcalth by Giles Fletcher", suppressed by order of Qucen Elizabeth. Sir Thomas Smithe's "Voiage and Entertainment in Rushia"; London, 1605; and Tradescant's "Viagc of Ambassad", now first printed entire from the MS. in the Ashmolean Museum, Oxford. Edited by E. A. Bond, Esq., of the British Museum.

Time East India Voyage of Sir Hexry Middleton. To be Edited by Bolton Corney, Esq. 
Irdia ix the Fiftentil Cextury. A collection of documents, comprising, in the first place, a translation of the travels of Abd-cr-Rizak, ambassador from Shah-Rokh in the years 1441-2-3, translated from the Persian into French by M. de Quatremère, and published in the "Notices des Yanuscrits", tome xvi, 1813. And, secondly, "The travels in India of the Tenetians Nicoló de' Conti and Giorgio di San Stefino." Translated from the Latin and Italian by J. Winter Jones, Esq., of the British Museum. The former of these last two documents will be translated from the original Latin, first printed in Paris in 1723, by Dominicus Georgius, in the fourth book of his edition of Poggio Bracciolini's "Historiæ de varietate fortunæe libri quatuor". Ramusio, in his "Navigatione et Viaggi", states that he made great efforts to discover the original, but without success, and was obliged to content himself with a Portuguese translation, full of inaccuracies, which he again translated into Italian for his great collection. The original Latin, apart from the important quality of being authentic, renders easy and intelligible many passages which are full of obscurity in the Italian of Ramusio. And, thirdly, "The travels of the Russian traveller Anastasius Nikitin." 'Translated by Count Wielhorsky, late Secretary to the Russian Legation at the Court of St. James's, from the Russian MS. procured for the Society by Sir Roderick Murchison from the celebrated and wealthy monastery called the Laura of St. Scrgius, under the Invocation of the Blessed 'Trinity, near Moscow. The work to be edited by J. Winter Jones, Esq., F.S.A., of the British Museum.

The Trayels of Girolano Benzoni, in America, in 1541 ; the first travcller (as such) in the New IVorld, and whose writings form the basis of the American portion of the great collection of travels compiled by Theodore de Bry. To be translated and edited by Admiral W. H. Smyth.

A Collection of Documexts on the Early Discoveries is Australia. To be edited by Captain C. R. Drinkwater Bethune, R.N., C.B.

Other works promised by Editors are :-

A Collection of Early Docunients, to form a Supplement to the "Narrative of Voyages towards the North West", by T. Rundall, Esq.

Sofalah. The History of Eastern Ethiopia, by J. dos Santos, 1607. To be Translated and Edited, with Notes, by IV. Desborough Cooley, Esq. 
The following six Members retire from the Council:

Rear-Admiral Sir Fraxcis Beaufort.

Boltox Cornex, Ese.

R. W'. Girer, Esq., M.P.

Sir Cinarles Lemox, Bart, M.P.

Sir Johr Richarisox, M.D.

Rev. W. Wheweli, D.D.

Of this number-

Sir Fraxcis Beaufort

R. W. Grey, Esq.

REV. Dr. WHEWELL

are recommended for re-election.

And the following are proposed for election, riz.:

D.rid B.illeie, Esq., F.R.S.

Lord Brovghtos.

C. IV. Dilike, Esq., Jun.

Statement of the Accounts of the Society for the year 1854.

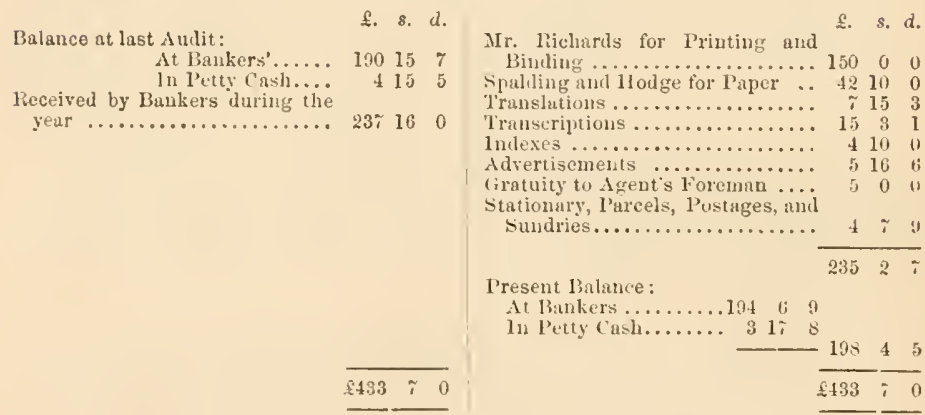

Examined and Approved, 28th Feb., 1855. JOHN BARROW, A. B. BECHER. 


\section{INTRODUCTION.}

The first work, in the following rolume of Arctic Niscellanies, is that of Frederick Martens, of Hamburg, describing a royage which he made to Spitzbergen in 1671, with a description of that great Arctic island, or rather archipelago, and the productions he observed on its shores or in the seas around. The book of Martens was translated from the German into English, and published in 1694 in a collection of voyages, entitled, "An account of several late Voyages and Discoveries to the South and North, towards the Streights of Magellan, the South Seas, the vast tracts of land beyond Hollandia Nora, etc., also towards Nova Zembla, Greenland or Spitzberg, Groynland or Engrondland, etc., by Sir John Narborough" and others. This translation and the other narratives were dedicated by the publishers (who were "Printers to the Royal Society") to the celebrated "Samuel Pepys, Esq., Secretary of the Admiralty of England." It seems, on the whole, to be a very exact translation of Martens' book. 'The plates, which in most eases are very rude, it has not been 
considered advisable to reproduce, although some of them are graphic and intelligible enough. And here it may not be unacceptable to quote what the anthor himself says respecting his production, in his address to the reader in the original German edition, - which address was left untranslated in the English version of the work now reprinted.

"When," he says, "I undertook some years ago an expedition to Spitzbergen, I resolved to commit to paper an account of my royage, and to make drawings of any objects that admitted of pictorial illustration. On my return, I showed my notes and drawings to several distinguished friends, and among others to Dr. Kirstenius and to Dr. Fogel, who not merely expressed their satisfaction at the result of my labours, but recommended that my work should be published.

"When, however, I applied myself to my task, Dr. Fogel gave me a translation of the list of queries inserted in the 29th No. of the "Philosophical 'Transactions," by Mr. Oldenburg, ${ }^{1}$ upon points especially requiring clucidation with regard to Spitzbergen, and hence I was led to cnlarge my account of my travels to the extent of one half, and that not from other books, but entirely from my own experience. Nor do I doubt that, though I have not been able to answer every question, I have at least in some cases satisfied the desires of the cminent curiosi above mentioned; for I have not only noted day by day the weather,

${ }^{1}$ Henry Oldenburg, secretary of the Royal Socicty and editor of the "Philosophical Transactions" from 1665 to 1677 . 
and, whenever possible, the latitude, but I have also griven in four divisions a copious account of Spit\%bergen as regards the land, the sea, the ice, the air, the wind, the snow, the rainbows, and also the plants and animals, and more especially the whales and the whale fishery.

"Dr. Fogel's numerous inquiries have also increased the work, by eliciting a great amount of information upon points which would otherwise have escaped me. Dr. Fogel has also arranged the work in proper order, and in such a manner that any point can be found without the need of an index. He has also identified sereral plants, and determined the classes to which they belong, and has invented several appropriate designations for plants and animals, which had previously had no German name. For all which services I now publicly offer him the thanks which are so justly his due."

The following are the queries in the "Philosophical 'Transactions" above referred to :-

\section{"INQUIRIES FOR GREENLAXD.}

"To discharge our promise made in the last "Transactions," we shall subjoin the following queries, which we also purpose to recommend in due season, to some of those English masters of ships and other fit persons that shall sail into Greenland for the whale-fishing: intreating withall, as many as have conveniency, to assist us in these recommendations.

"I'he inquiries are :-

"1. What and how much is the heat of the sun there in 
the midst of the summer, compared with the heat of it in England? to be observed with a seal'd thermometer.

" 2 . What is the most constant weather there in summer, whether clear, cloudy, rainy, foggy? etc.

" 3 . What weather is most usual at such and such times of the year?

"4. What constancy or unconstancy there is of the wind to this or that quarter of the horizon, or to this or that part of the year?

" 5 . What the temperature of each particular wind is observ'd to be? and particularly whether the north-uind be the coldest? If not, what wind is? whether is the colder, the east or west, etc.

" 6 . What wind is observed to bring most ice, and what to make a elear water at sea?

"7. What currents there are? How fast, and which way they sett? Whether those currents are not stronger at one time of the moon than at another? Whether they always run one way?

" 8 . What is observable about the tydes, spring or neap? How high the high-water is above the low-water? which way it floweth? which way it ebbeth? what time of the moon the spring-tides fall out?

"9. Whether the ice that floats in the sea be of salt water or fresh?

"10. What ricers there are in the summer, and what fresh water can be had?

"11. What fowl are found to live there, and what beasts? How they are thought to subsist in winter? How they breed and feed their young?

"12. What cegetubles grow there, and whether they yicld any flowers or firuits, etc.?

"13. Whether there have been any thunder or lightning observed in those parts?

"11 How docp the cold penctrates into the earth? 
Whether there be any wells, pitts, or mines, so decp that the cold does not touch the bottom thereof?

"15. How the land trends? and whether the parts under" or near the Pole be by those that have gone furthest that way thought to be sea or land? How near any hath been known to approach the Pole; and whether the cold increaseth with the increase of lutitude?

"16. To make, if possible, some experiments or observations about the magnet or needle; and particularly, how much the dectination is there? and whether they doe exactly observe the degrees of declination in their course? Likewise to make obscrvations about the height of the sun and other celestial bodies, and their diameter, refractions? ctc.

"17. What is their opinion concerning the North-east passage?

"18. What fish do most frequent those seas, bcsides whales? Any thing observable in their fishing? as the usual or unusual bigness, strength, and the several sorts of whales; and particularly to observe whether that kind of uchales they call Trompa, have in their heads the sperma ceti, and in their cntrals the ambergreese, looking like cowsclung, as was alledged out of Purchas, in numb. 28, pag.5.38?

"19. To give in an exact relation of the whale-fishing, throwing the harp-irons, following the fish, etc.

"20. To describe the whole manner of making the oyl of whales."

Martens' work was the first published on Spitzbergen, and in its description of the ice and animals especially, seems to be very correct and graphic, and it gives a rery good account of the mode pursued by the Dutch, in the capture of the whale and the wrilius, more than a century and a balf ago; 
and this account was not superseded till Capt. (now the Rev. Dr.) Scoresby published his account of the Arctic Regions, and his history and description of the Northern Whale Fishery in 1820. In this excellent work, section 1 of chapter II is devoted specially to an account of Spitzbergen and the islands immediatcly adjacent. One of the plates contains a survey of Spitzbergen, the west coast being laid down from the author's own observations. In the appendix to this edition of Martens', a few extracts are given relating to the animals of Spitzbergen and the surrounding scas, from Dr. Scoresby's volumes. In another of Dr. Scoresby's works, that in which he describes his discoveries on the east coast of Greenland in 1822, he gives some pictures of the "highly striking, interesting, and indeed magnificent" scenery of Spitzbergen. ${ }^{1}$

The voyage towards the North Pole by Captain Phipps (afterwards Lord Mulgrave) in 1773, contributed a good deal to our knowledge of the natural history of Spitzbergen and the surrounding seas. His journal of this royage was published in the following year, and in the introduction he mentions the assistance he derived from Sir Joseph Banks: "To Mr. Bankis I was indebted for very full instructions in the branch of natural history, as I have since been for his assistance in drawing up the account of the productions of that country." In the appendix, there

1 "Joumal of a Voyage to the Northern Whale Fishery, including researches and discoveries on the eastern coast of West Greenlint, mate in the summer of 1822 , in the ship Batfin, of Liverpool." Edinburgh, 1823. 
is giren a catalogue of fifty-one subjects of the animal kingdom; some of these were there described and figured for the first time. In the appendix to the following edition of Martens' Spitzbergen, the whole of these are included. In the same appendix, twentyseven plants are recorded, one of which, a grass (Agrostis algida) described there for the first time, was subsequently described by Mr. Brown, as the type of a new genus named Phippsia, in honour of the brave commander of the expedition. The immortal Nelson, then a mere youth, went on this expedition with his uncle Captain Lutwidge, and we learn from Southey's life of the naval hero, that on two occasions, at least, the young midshipman contended both with the Polar bear and the unvieldy walrus. A number of the latter animals had attacked a boat; they "were with difficulty prerented from staving or oversetting her, but a boat from the Carcass joining ours", says Captain Phipps, "they dispersed". ${ }^{1}$ Sonthey informs us that this boat was commanded by Horatio Nelson. ${ }^{2}$

Another celebrated name in Aretic enterprise and discovery acquired his first experience of Aretic dangers in the Spitzbergen seas. Sir J. Franklin was lieutenant and commander of the Trent, in the "voyage of discovery towards the North Pole performed in His Majesty's ships Dorothea and Trent, under the command of Captain David Buchan, R.N.", in 1818. Captain (now Admiral) F. W. Beechey published the narrative of this voyage in 1843 . He has given a

1 Phipps, Voyage towards North Pole, p. 58.

${ }^{2}$ Life of Nelson, p. 10. 
most graphic account of Spitzbergen and the surrounding seas. In this book are many excellent remarks on the animal productions of this inhospitable land, with some admirable views and sketches. In the appendix to this edition of Martens', some valuable extracts from this work are included in the list of the animals. The following descriptive extract from Admiral Becchey's rolume, conveys a striking picture of a fine summer day in these generally wintry climes. The royage of the Dorothea and Trent was not more successful than that of the Racehorse and Curcuss forty-five years before; but it served, at all crents, as the nursery of three great Arctic explorers, -the lamented Franklin, and the present Admirals F. IV. Beechey and Sir G. Back; while it afforded a subject for one of the most pleasing of all the Arctic narratires, the book from which the following interesting extract is derived.

"In cloudy or misty weather, when the hills are clothed with newly-fallen snow, nothing can be more dreary than the appearance of the shores of Spitzbergen; whereas, on the contrary, it is scarcely possible to conceive a more brilliant and lively effect than that which occurs on a finc day, when the sum shines forth and blends its rays with that peculiarly soft, bright atmosphere which overhangs a country deeply bedded in snow; and with a pure shy, whose azure hue is so intense as to find no parallel in nature. On such an occasion the winds, near the land at least, are very light, or entirely hushed, and the shores tecm with living objects. All nature secms to acknowledge the 
glorious sunshine, and the animated part of creation to set no bounds to its delight.

"Such a day was the 4th of Jume, and we felt most sensibly the change from the gloomy atmosphere of the open sea, to the cheerful glow that overhung the hills and placid surface of Magdalena Bay. Althongh surrounded by beds of snow and glaciers, with the thermometer scarcely above the freczing point, there was no sensation of cold. The various amphibious animals, and myriads of birds which had resorted to the place, seemed to enjoy, in the highest degree, the transition thus occasioned by a few bright hours of sunshine. From an early hour in the morning until the period of rest returned, the shores around us reverberated with the merry cry of the little auk, willocks, divers, cormorants, gulls, and other aquatic birds; and wherever we went, groups of walruses, basking in the sun, mingled their playful roar with the husky bark of the seal.

"There was certainly no harmony in this strange din; but it was at least gratifying to know that it arose from a demonstration of happy feelings. It was a pleasure of the same character as that which must have been experienced by every traveller, who, on some fine bright evening in a tropical climate, has listened to the merry buzz of thousands of winged insects which immediately succeeds the setting of the sum; and here we cannot fail to notice the manner in which the great Author of Nature has varied IIis dispensations. In the burning region of the torricl zone, the descent of the sun calls into action myriads of little beings which could not exist under the fierce 
glare of his meridian ray; whereas here, on the contrary, it is the signal for universal repose.

"This period of the day had no sooner arrired in Magdalena Bay than there was a stillness which bordered on the sublime-a stillness which was interrupted only by the bursting of an iceberg, or the report of some fragment of rock loosened from its hold. These sounds, indeed, which came booming over the placid surface of the bay, could hardly be considered interruptions to the general silence, for, speedily dying away in the distance, they left behind a stillness even more profound than before.

"In the daytime, the presence of our expedition was not disregarded. The birds shmnned us in their flight, and every noise which was occasionally made, sounding strange to the place, sent to a greater distance the seagulls that were fishing among the rocks, and kept on the alert whole herds of animals, many of which would otherwise have been lost in sleep; causing them to raise their heads when anything fell upon our cleck, and to cast a searching look orer the bay, as if to inquire whence so unusual a disturbance proceeded. These little alarms, which would have passed unheeded in situations frequented by man, proved, more than any other incident, how great at stranger he was in these regions; a feeling which, I must confess, carried with it an agrecable sensation, arising, no doubt, from the conviction that we were treading on ground which had been but rarely visited before."

1 Toyage of Discovery towards the North Pole, performed in his Majesty's ships Dorothea and 'Trent, under the command of Captain 
On the 11th May, 1823, Captain Clavering in the Griper, accompanied by Captain (now Colonel) Sabine, sailed for Spitzbergen. 'The chief object of the expedition was the continuation of a series of observations on the length of the second's pendulum. 'They landed on a small island, the same as that on which Captain Phipps made his observations, in 1773. Captain Clavering left Captain Sabine and a party to make observations, while he pushed to the northward; but in lat. $80^{\circ} 20^{\prime}$, his further progress was arrested, like that of Lord Mulgrave, by the ice, along the margin of which he sailed in a westerly direction for about sixty miles; perceiving no opening, he returned to Captain Sabine's station, and afterwards visited the coast of Greenland.

In 1826, Admiral Sir Edward (then Captain) Parry proposed to the Admiralty, to attempt to reach the North Pole by means of travelling with sledge-boats over the ice or through any spaces of open water that might occur. This proposal was referred to the President and Council of the Royal Society, who recommended strongly its adoption, and on the 25th of March, H.M.S. Hecla sailed for Spitzbergen. Although the primary object of the expedition was frustrated, Captain Parry succeeded in reaching a point nearer to the North Pole than had been or has yet been attained, and his admirable narrative with its views and charts has added much to our aequaintance with the appearance and geography of the northern part of Spitzbergen; while, to say nothing David Buchan, R.N., 1818, and by Capt. F. Wr. Beechey, R.N., F.R.S., pp. 52-55. 
of the valuable meteorological and magnetic observations of himself and Captains Foster and Crozier, there is a very interesting Zoological Appendix by Captain Sir James C. Ross, and an equally valuable Botanical Appendix by Sir William Hooker. Of mammalia, 9 species are recorded; and the numbers of the other orders are as follows: birds, 21 ; fishes, 4; insects, 1 ; radiata, 5 ; crustacea, 14 ; and molInsca, 2. Of the plants, 40 belong to the phænogamous division; while 50 are recorded which belong to the cryptogamic section of plants.

In the appendix too, is given by the late Professor Jameson, an enumeration of the rocks of Spitzbergen and the neighbouring islands. From this we learn, among other interesting mineralogical facts, that some mould from "Hecla Core", a place where the soil is good and covered with a tolerably abundant vegetation, contains 70 per cent. of silica; the other ingredients being water, 12 per cent.; carbonate of lime, $S$ per cent.; carbonate of iron, 3 per cent.; and a slight portion of vegetable débris. Ross's Islet, the most northern known land on the globe, seems to be a primitive rock, the specimens of it brought consisting of grey and reddish granite-gneiss with imbedded precious garnets. So that of all the gems, the precious garnet seems to have the widest geographical range.

In a letter to Sir John Barrow, published in "Voyages of Discovery and Research within the Aretic Regions from the year 1818 to the present time" (1846), Sir Edward Parry observes: "It is evident that the causes of failure in our former attempt in the year 1827 were principally two; first and chicfly, the broken, 
rugged, and soft state of the surface of the iee over which we travelled; and secondly, the drifting of the whole body of ice in a southerly direetion. On mature reconsideration of all the eireumstances attending this enterprise, I am induced to alter the opinion I gave as to its practicability in my journal, p. 144; beeause I believe it to be an objeet of no very difficult attain.ment if set about in a different manner. My plan is to go out with a single ship to Spitzbergen, just as we did in the IIecla, but not so early in the season; the object for that year being merely to find secure winter quarters as far north as possible. For this purpose it would only be necessary to reach Hakluyt's Headland by the end of June, which would afford ample leisure for examining the more northern lands, especially about the Seven Islands, where, in all probability, a secure nook might be found for the ship, and a starting point for the proposed expedition, some forty or fifty miles in advance of the point where the Hecle was before laid up. The winter might be usefully employed in various preparations for the journey, as well as in magnetic, astronomical, and meteorological observations of high interest in that latitude. I propose that the expedition should leave the ship in the course of the month of April, when the ice would present one hard and unbroken surface, over which, as I eonfidently believe, it would not be difficult to make good thirty miles per day without any exposure to wet, and probably without snowblindness. At this season, too, the ice would probably be stationary, and thus the two great difficulties which we formerly had to encounter would be entirely obvi- 
ated. It might form a part of the plan to push out supplies previously to the clistance of a hundred miles, to be taken up on the way, so as to commence the journey comparatively light; and as the intention would be to complete the enterprise in the course of the montl of May, before any disruption of the ice or any material softening of the surface had taken place, similar supplies might be sent out to the same distance to meet the party on their return."-l. $c$. pp. 313-314.

The last scientific voyage made to Spitzbergen was that of the French naval officer, Captain Gaimard. A portion only of the narrative of this voyage has been published. Among the plates are some striking views of the scenery and illustrations of the natural history. 'The celebrated Danish zoologist, Kroyer, seems to have been on this expedition, so that when completed, a fuller account than has yet been pub. lished of the animal and vegetable productions, may be expected, as well as of the geological structure of the parts of the island which they visited. In the list of animals appended to this edition of Martens', are included such as have becn described by Kroyer in his "Naturhistorisk 'Yidskrift", as found for the first time by the French expedition in the bays of this Arctic land.

'The reader who wishes to know the history of Aretic discovery in Spitzbergen, must consult Dr. Forster's learned work on the History of the Voyages and Discoveries made in the North, the two excellent works of the late Sir John Barrow, and Captain Beechey's naruative, already alluded to. It is to be 
hoped that, at no very remote period, such parts of the coast of Spitzbergen as have not been visited, may be explored by some of our steamboats in favourable seasons, as the results of Captain Gaimard's expedition shew that there are yet many "gleanings" to be gathered in the natural history, as we know there are in the geography, of that finest and most accessible of the islands within the Arctic circle.

The second document in the volume is a translation, now newly made, from the "Relation du Groenland" of Isaac de la Peyrère, so celebrated for his strange opinions on the subject of men existing on the globe before Adam. It was during a residence in Denmark in 1644, with M. de la Thuillerie, ambassador from France to Copenhagen, that he compiled his "Relation de l'Islande" published with his name in Paris, 1663; and at the same time collected the materials for his "Relation du Groenland," the work now translated, which he dates from the Hague, 1646, but which likewise remained unprinted till 1663, when it appeared anonymously. Niceron, in his "Mémoire pour servir à l'histoire des Hommes illustres", in referring to these two works, with justice remarks, "Elles sont toutes les deux curienses et estimées, et La Peyrère n’y paroit nullement visionnaire, comme il l'a paru dans ses autres ourrages. Il les écrivit pour faire plaisir à M. la Mothe le Vayer, son ami, que aimoit ces sortes de livres." The "Relation du Groenland" was reprinted in the first volume of the "Recueil des Voyages au Nord," and a translation was given in Churchill's Collection. As a 
compendious account of the early expeditions to that country, as well as of the habits and manners of the people, it has been deemed, especially in its new shape, an appropriate document for insertion in this collective volume.

We may here take occasion to insert a curious epitaph, inclited after the death of the author, cipropos of the instability of his religious opinions:-

"La Peyrère ici gît, ce bon Israelite, Huguenot, Catholique, enfin Préadamite, Quatre religions lui plurent à la fois, Et son indifférence étoit si peu commune Qu'après quatre-vingt ans qu'il eut à faire un choix, Le bon-homme partit et n'en choisit pas une."

We find, howerer, from an extract from the registers of the parish of Ambervilliers, where he was buried, that he abjured all his heresies at the feet of Pope Alexander VII, and died "muni de tous ses sacremens" on the 31 st of January 1676 , at the venerable age of eighty-three.

The interesting document which closes the rolume, entitled, "God's Power and Providence, showed in the Miraculous Preservation and Deliverance of eight Englishmen left by mischance in Greenland, amno 1630, nine moneths and twelve dayes," is now very scarce. A copy, with the map, which is frequently wanting, is quoted by Lowndes as being sold for four pounds. Hence, although reprinted in Churchill's Collection, it has, from its interesting character and intimate connection with the subject, been considered a fitting document to insert in the present rolume. 


\section{OY A G E}

\section{SPITZBERGEN AND GREENLAND.}

PART THE FIRST.

CONTAINING THE PASSAGES OF THE WHOLE VOYAGE, TOGETHEI WHTH SOME ACCONNT OF THE WEATHER, FROM THE 15TH OF APRIL, TO THE 2IST OF AUGUST, ANNO 16:1. 



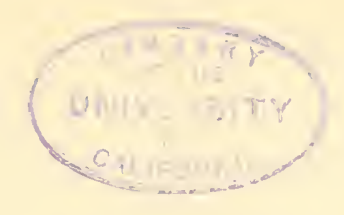

\section{VOYAGE INTO SPITZBERGEN,}

ETC.

CHAP. I.

of the Voyuge from the Elbe to Spitzbergen.

WE set sail the 15th of April 1671, about noon, from the Elbe. The wind was north-east; at night, when we eame by the Hilge-land, ${ }^{1}$ it bore to north-north-east. The name of the ship was Jonas in the Whale, ${ }^{2}$ Peter Peterson, of Friseland, master.

The 2rth, we had storms, hail and snow, with very cold weather, the wind north-east and by east; we were in seventy-one degrees, and came to the ice, and turned back again. The Island of John Maicn bore from us south-west and by west, as near as we could guess within ten miles. We might have seen the island plain enough, but the air was haizy, and full of fogs and snow, so that we could not see far. About noon it blew a storm, whereupon we took down our topsails, and, furling our mainsail, drove with the missensail towards south-cast.

The 29 th, it was foggy all day, the wind north-east, and by north; we came to the ice, and sailed from it again.

1 "Heilige-land," the "Heligoland" of British maps.

2 In the original German there is given here a portion of the $\log$ of the "Jonas im Wulfisch"; similar passages are occasionally omitted in the translation. 
The 30th, the first Sunday after Easter, was foggy, with rain and snow, the wind at north; at night we came to the ice, but sailed from it again; the sea was tempestuous, and tossed our ship very much.

The 3rd of May was cold, snowy, with hail, and misty sunshine; the wind north-west and by west; the sun set no more, we saw it as well by night as by day.

The 4th, we had snow, hail, and gloomy sunshine, with cold weather, but not excessive; the wind at north-west; the weather every day unconstant. Here we saw abundance of seales $;$ they jumped out of the water before the ship, and, which was strange, they would stand half out of the water, and, as it were, dance together.

The 5th, in the forenoon, it was moderately cold, and sunshine, but toward noon darkish and cloudy, with snow and great frost; the wind north-west and by north. We saw daily many ships, sailing about the ice; I observed that as they passed by one another, they hailed one another, crying Holla, and asked each other how many fish they had caught; but they would not stick sometimes to tell more than they had. When it was windy, that they could not hear one another, they waived their Hats to signific the number caught. But when they have their full fraight of whales, they put up their great flag as a sign thereof: then if any hath a message to be sent, he delivers it to them.

The 7 th, we had moderate frosts, clouds and snow, with rain. In the evening we sailed to the ice, the wind was quite contrary to us, and the ice too small, wherefore we sailed from it. In the afternoon we saw Spitzbergen, the south point of the North Foreland: we supposed it the true Harbour. The lind appeared like a dark cloud, full of white strecks; we turned to the West again, that is, according to the compass, which is also to be understood of the icc and harbour.

I "Sec Humle"-seals. (Phoca Grenlandica?) See Aypendix. 
The 9th was the same wcather, and cold as before, the wind south-west and by west. In the afternoon a fin-fis/ ${ }^{1}$ swam by our ship, which we took at first to be a whale, before we saw the high fins of his tail and came near to it. We had let down our sloop from the ship, but that labour was lost, for he was not worth taking. From the 25th of Aprit to this day we had not taken the sun's altitude; we were then in serenty degrees and three minutes, and sailed towards the north and the ice. It may seem strange that we so often sailed to the ice and from it again, but I shall give you a reason for that hereafter.

The 12th, it was stormy and excessive cold, the wind North, and we had the greatest frosts in this Month of May.

On the 14th, the wind was north-west, fine weather with sunshine; we were within seventy-fire degrees and twentytwo minutes. We told twenty ships about us; the sea was very even, and we hardly felt any wind, and yet it was very cold. In this place the sea becomes smooth presently again after a storm, chiefly when the wind blows from the ice; but when it blows off the sea, it always makes a great sea. The same day we saw a whale, not far off from our ship; we put out four boats from on board after him, but this labour was also in rain, for he run under the water and we saw him no more.

On the 19th, we had a dull sunshine, the wind was north, and it was so calm that we could hardly feel it; we rowed in the ship-boat to the ice, and killed two sea-hounds (or seales); there were so many on the ice they could not be numbered.

On the 20th, it was exceeding cold, so that the very sea was all frozen over; yet it was so calm and still that we could hardly perceive the wind, which was north; there were nine ships in our company, which sailed about the ice ; we found still, the longer we sailed the bigger the ice.

1 "Finnen-fish." (Bulena Pleysalus, O. Fabr., Physalus Antiquorum? of modern authors.) 
On the 21st (which was the fourth Sunday after Easter), we sailed into the ice in the forenoon, with another Hamburgher-ship, called the Lepeler, with eight Hollanders. We fixed our ship with ice-hooks to a large ice-field, when the sun was south-west and by south; we numbered thirty ships in the sea; they lay, as it were, in an harbour or haven. 'Thus they venture their ships in the ice at great hazard.

On the 30th, it was fair weather in the morning, snowy about noon, the wind was south-west and very calm. We rowed in the great sloop, before the ship, farther into the ice. In the morning we heard a whale blow when the sum was in the east, and brought the whale to the ship when the sun was at south-west and by east; the same day we cut the Fat from it, and filled with it seventy barrels (which they call kardels). By this fish we found abundance of birds, most of them were mullemucks ${ }^{1}$ (that is to say, foolish gnats), which were so greedy of their food, that we killed them with sticks. 'This fish was found out by the Birds, for we saw everywhere by them in the sea where the whale had becn, for he was wounded by an harpooning iron that stuck still in his flesh, and he had also spent himself by hard swimming; he blowed also very hollow, he stank alive, and the birds fed upon him. This whale fermented when it was dead, and the steam that came from it inflamed our eycs and made them sorc. This same night, Cornelius Seaman ${ }^{2}$ lost his ship by the squcezing and crushing together of the ice; for in this place are very great sheets or islands of ice, and the seamen call it West-ice, because it lieth toward the west.

On the and June, we had a serere frost in the forenoon, and in the night we saw the moon very pale, as it used to look in the daytime in our country with elear sunshine, whereupon followed mist and snow, the wind north-east and by north.

\footnotetext{
1 "Mallemücken." 'The Fulmar Petrel (1'rocelluria glacialis.)

2 "Acman," orig.
} 
In the morning, June th, we were a-hunting again after it whale, and we came so near unto one, that the harpoonier was just a going to fling his harpoon into her, but she sunk down behind and held her head out of the water, and so sunk down like a stone, and we saw her no more; it is very like that the great ice-field was full of holes in the middle, so that the whale could fetch breath underneath the ice. A great many more ships lay about this sheet of ice; one hunted the whales to the other, and so they were frighted and became rery shy. So one gets as many fishes as the other, and sometimes they all get one. We were there several times a hunting that very day, and yet we got never a one.

On the Sth, it was foggy, and snowed all day; we saw that day very many sea-logs (or seales) on the ice about the sea-side, so we set out a boat and killed fiftcen of them.

On the 12th, it was cold and stormy all day, at night sunshine; he that takes not exact notice, knows no difference whether it be day or night.

On the 13th, in the afternoon, it was windy and foggy; we were in seventy-seven degrees; we sailed along by the ice somewhat easterly towards Spitzbergen. 'That night we saw more than twenty whales, that run one after another towards the ice; out of them we got our second fish, which was a male one; and this fish, when they wounded him with lances, bled very much, so that the sea was tinged by it where he swam; we brought him to the ship when the sum was in the north, for the sun is the clock to the seamen in Spitzbergen, or else they would live without order, and mistake in the usual seven weekly days.

On the 14th, it was cold and windy, the night foggy, the wind blew west; that day we came to Hans Lichtenberg.

We arrived at Spitzbergen June the 14th. First we came to the Forcland thereof, then to the seven Ice-hills or mountains, then we passed the harbours (or bays) of the Hamburghers, Magdalens, of the English men, and Danes, and sailed into 
the South Bay: we were followed by seven ships, three Hamburgher's and four Hollanders. For here it is just the same as when they will sail into the ice, if more than one is there; for nobody eares to be the first, because they do not know in what condition the harbour or the ice is within. In our voyage thither we saw no ice at all, until we came to Spitzbergen, for the wind has blown it all away; in the night we did cut off the fat of the fish, and filled with it sixty-five kardels or vessels.

That night we sailed with three boats into the English harbour or bay, and saw a whale, and flung into him three harpoons, and threw our lances into him; the whale ran underneath the small ice, and remained a great while under water before he came up again, and then ran but a very little way before he came up again; and this he repeated very often, so that we were forced to wait upon him above half an hour before he came from underneath the ice. The harpoons broke out at length, and we lost him. On the ice we saw two great sea-horses or morses, ${ }^{1}$ that were got upon the sheet of ice, through a hole that was in it, and were asleep; we cut off their retreat by covering the hole with a piece of ice; then we awakened them with our lances, and they began to defend themselves for awhile before they were killed. We saw also many white fish.

On the 22nd, we had rery fair weather, and pretty warm; we were by Rehenfelt (Deersfield), where the ice stood firm. We saw six whales, and got one of them that was a male and our third fish; he was lilled at night when the sun stood westward: this fish was killed by one man, who flung the harpoon into him; and killed him also, while the other boats were busy in pursuing or hunting after another whale. This fish run to the ice, and before he died beat about with his tail; the ice settled about him, so that the other boats could not come to this boat to assist him, till the ice separated

1 "Walrosse" - - the walrus (Trichechus rosmarus). Sec Appendix. 
again that they might row, when they tied one boat behind the other, and so towed the whale to the great ship, where they cut him up into the vessels, and filled with him fortyfive barrels. 'This night the sun shined very brightly.

On the 29 th, we had fair weather, sunshine, and calm. On the same day we sailed before the wide harbour or bay, where we found a great quantity of the fat of a whate, three vessels full, together with the image of St. Nicholas, which stood behind a ship that was lost driving in the sea: there was also here and there still much ice.

On the 1st July, about noon, two whales came near to our ship; we saw that they had a mind to couple together; we set our boat for them, and the harpoonier hit the female, which when the other found, he did not stay at all, but made away. The female run all along above the water, straight forward, beating about with her tail and fins, so that we durst not come near to lance her ; yet one of our harpooniers was so foolhardy to venture too near to the fish, which saluted him with a stroke of her tail orer his back so vehemently, that he had much ado to recover his brcath again. Those in the other boat, to show their valour also, hastened to the fish, which overtumed their boat, so that the harpoonier was forced to dive for it, and hide his head underneath the water; the rest did the same; they thought it very long before they came out, for it was cold, so that they came quaking to the ship again. In the same morning a whale appeared near our ship, before the wide harbour: we put out four boats from our ship after him, but two Holland ships were about half a league from us; one of them sent a boat towards us; we used great diligence and care to take him, but the fish came up just beforc the Dutchman's boat, and was struck by him with the harpoon. Thus he took the bread out of our months.

On the and of July we had sunshine all day and night long, and it was pretty warm withall; about midnight we 
went a hunting, and caught the fifth fish, who was a male; we cut the fat off and flung it into the forecastle. 'This is done when they are very busy in whale catching, that they may not lose time; then they cut great pieces off the whale, that they may have done the sooner, for it doth not harm the fat if it should lie so for several days; nay, some reckon it to be the better for it, but that cannot be, for the fat runs away from it.

On the 4th, we had sunshine all day and night. We still were whale hunting, and that night we got the sixth fish, a male also; he held forty-nine kardels of fat.

On the 3rd and 4th day of July, we saw more whales than we did in all our voyage.

On the 5th July, in the forenoon, it was bright sunshine and pretty warm; in the afternoon it was foggy; at night sunshine again, which lasted all the night. We hunted all that day long, and in the morning we struck a whale before the IVeigatt; this fish run round about under the water, and so fastened the line whereon our harpoon was about a rock, so that the harpoon lost its hold, and that fish got away. This whale did blow the water so ficrcely, that one might hear it at a league's distance.

'The same day, about noon, the wind south and sunshine, we got the seventh fish, which was a female, and had fortyfive liardels of fat; this we cut also into the hold, and so we sailed from Weigatt, a little toward the west, before the Muscle-harbour, where we dropt our anchor; we were employed in cutting the great pieces of fat into lesser pieces, to fill our kardels with them; in the mean while the wind turned to the north-west and west, and the single anchor was dragged by the ship, so we dropped another, and would have weighed up the former, but our cable broke, the anchor being fastened to a rock.

On the 6th, we had the same weather, and warm sunshine all night. Hard by us rode a Hollander, and the ship's erew 
busic in cutting the fat of a vhale, when the fish burst with so great a bounce as if a eannon had been discharged, and bespattered the workmen all over.'

On the Sth, the wind turned north-west, with snow and rain. We were forced to leave one of our anchors, and think'd God for getting off from land, for the ice eame on ficreely upon us; at night the wind was laid, and it was colder, although the sun shined.

On the 9th, we got another male whale, being the eighth, which was yellow underneath the head; we filled with him fifty-four kardels of fat; the sum shined all night.

On the 12th, we had gloomy sunshine all day, at night we sailed with three boats into the ice before the Weigatt, and got three white bears, ${ }^{2}$ an old one and two young ones, they swam in the water like fish. On the ice lay abundance of sea-horses, and the further we came into the ice there were the more of them; we rowed up to them, and when we eame near to them we killed ten of them; the rest came all about our boat, and beat holes through the sides of the boat, so that we took in abundance of water; we were forced at length to row away because of their great number, for they gathered themselves more and more together; they pursued us as long as we could sce them, very furiously. Afterwards we met with another very great one, who lay in the water fast asleep, but when he felt our harpoon within him he was very much frightened, and ran away before the boat again, where he was soon eased of his fright by our lances. We saw but very few uhales more, and those we did see were quite wild, that we could not come near them. That night

${ }^{1}$ Putrefaction had commenced. Captain (now the Rev. Dr.) Scoresby tells us, that at such a time "the whale swells to an enormous size, until at least a third of the carcase appears above water, and sometimes the body is burst by the force of the air generated within." - Arctic liegions, i, p. 466.

2 The Polar bear (Thalassarctos maritimus), the despot of the Arctic regiuns. See Appendix. 
it was so dark and foggy, that we could hardly see the ship's length; we might have got sea-horses enough, but we were afraid of loosing our ships, for we had examples enough of them that had lost their ships, and could not come to them again, but have been forced to return home in other ships. When after this manner any have lost their ships, and camnot be scen, they discharge a cannon from the ship, or sound the trumpets, or hautboys, according as they are provided in their ships, that the men that are lost may find their ship again.

On the 13th, we had cloudy sunshine, the wind tow'rds night turned to north-east and by east. The ice came afloating down apace, we sailed from the south-cast land to the west, and we could but just get through by the north side from the Bear Harbour or Bay. We sailed on to the Rehenfclt (or Deer Field), where the ice was already fixed to the land, so that we could but just get through; we sailed further to the Vogelsanck (Bird's-song). Then we turned to the east with a north-east wind, in company with twelve ships more, to see whether there were any more whales left, with George and Cornelius Mangelsen, and Michael Appel, who sailed in four fathoms water, and touched upon the wreck of a ship that was lost there.

On the 14th, in the morning, we sailed still among the ice, the wind being north-east and by east; we had a fog all that day with sumshine, with a rainbow of two colours, white and pale yellow, and it was very cold, and we saw the sun a great deal lower.

On the 15th, it was windy, cold, and foggy the whole day; the wind turned north-west, and the ice came on in abundance, so that we could hardly sail, for it was everywhere full of small sheets of ice. At this time there were many ships leset with ice in the Deer or Muscle Bay. We sailed all along near the shoar; at night we entered the South-harbour, where twenty-eight ships lay at anchor, cight whereof were 
IIamburgers, the rest Dutchmen. From that time when we sailed out of the South-haren we kept always within sight of the land, and saw it always, except it was foggy ; and so long the skippers stay by the ice to see if there are any more whales to be had. 'That night we fetched water from the land, near the Cookery of Harlingen, out of a hole.

On the 16th, in the morning, we saw the moon, and afterwards it was windy, with abundance of snow.

On the 1Sth, we had fair weather, with sunshine, and we were also becalmed that we could not sail, wherefore we towed with a boat into the Danish-harbour to gather some herbs from the rocks. In the South-haven rode thirty ships at anchor.

On the 19th, we had warm sunshine and fair weather, but in the night stormy and rain.

On the 20th, storms, rains, and a great deal of snow, the wind south-west.

On the 21st, rain all day long.

CIIAP. II.

Of our home voyage from Spitzbergen to the Elbe.

Ox the 22nd day of July, in the morning, when the sun was north-cast, we waied our anchors, and sailed out of the Southhaven. We had a fogg all day long, and sunshine at night; in the night we saw abundance of fin-fishes.

On the 24 th, it was so warm with sumshine, that the tarr wherewith the ship was daubed over melted; we 
drove, it being calm, before the haven or Bay of Magdalen.

On the 25 th, it was cloudy and sunshine, but cold withal; at night we came to the Forelunds, the night was foggy, the wind south-west.

On the 26th, we had the very same weather all day, the sun was very low in the night.

On the 28th, we turncd from the side of the North Foreland towards the west, when the sun was south-east; and we did sail south-west and by west towards the sea; then we changed our course southwards and stood south-east.

On the 99 th, 30th, and 31 st, we sailed sonth-east and by south all along by the land, the south side of the Foreland was eight leagues from us, bearing north-east; then we sailed south-west and by south, it was very cold, with a north-west wind. We saw daily abundance of fin-fishes, but no more whales.

On the 9th of August it was windy all day, with a gloomy sunshine in the forenoon; it cleared up towards noon: the wind was sonth-east when we took the meridian height of the sum, and were at sixty-six degrees forty-seven minutes; we sailed south-westward all along the northern shoar of the country.

On the 13th, being Sunday, in the morning the wind was north-west, stormy, witl rain and west winds. In the night we had very clear moon and starlight. In the morning we saw the northern part of Hitlend, we sailed southward; after the rain we saw Fair Isle, and sailed in betwixt Hitland and Fuir Isle, first south-west, and afterwards south-west and by south, and then southward.

On the 20th, it was fair weather, warm sunshinc, and somewhat windy; when the day began to appear we saw Irilgeland, south-castward of us, when we sailed south-east; there we took in a pilot, on purpose chosen by the magistrates of Hambury. 
On the 29 th, it was fair weather, and warm sunshine all day; we sailed before the Elbe, and lay at anchor by the first buoy (called the Red Buoy). In the afternoon we weighed our anchor, and sailed to Kucks-haven: in the night we had thunder and lightning and rain.

TIIE FND OF THE FIRST PART. 


\section{PAR'T THE SECOND.}

CONTAINING TIIE DESCRIPTION OF SPITZBERGEN.

\section{CHAP. I.}

Of the External Face and Appearance of Spitzbergen.

'T'ue lowermost parts of these countries, that are called Spitzbergen, from the sharp or pointed hills or mountains (for Spitz is pointed), are situated under seventy-six degrees and thirty minutes. We sailed to the eighty-first degree, and no ship ventured farther that year; but how far this comntry is extended to the north, is still unknown.

It secmeth, because the ice stands firm and floats not, as that in the sea doth, that there should be land not far behind it. As the highest countries are surrounded by mountains, as a fortification is with walls and works, so are these countries naturally surrounded with high hills.

'The inward condition of this country we do not know, but it seemeth, since we see one hill behind another, that it is so throughout the whole country. At the Muscle-haven or Muscle-Bay, we find plainer or leveller ground; and the farther we sail toward the east, the ground groweth the lower, yet it is all stony, and with prospects of smaller hills; it doth not look at all as if it conld be inliabited by men.

I believe also the land there must of necessity be lower and lower, for else we should see it higher above the other, as we do the other mountains. 
Concerning the beasts that live on this land, I believe they come over the ice in the spring, when the ice stands firm, into these comntries, and that the same way they go away from thence again, when the long nights begin. ${ }^{1}$

Concerning the birds, we have partly a good account of them; their places and food are known, as I shall mention when I come to write about them.

When, on the 18th of June, on a Sunday, in the forenoon, we first came to the Foreland of Spitzbergen, the foot of these mountains looked like fire, and the tops of them were covered with foggs; the snow was marbel'd, and looked as if it were boughs and branches of trees, and gave as bright and glorious a gloss or shining to the air or skies as if the sum had shin'd. When the mountains look thus fiery, a hard storm generally ensucs.

'These countries are in the winter encompassed with ice from divers places, according as the winds blow; as, if it be east, from Nora Zembla, if north-west, from Greenland and the island of John Mayen: it also happeneth sometimes that the land is begirt with ice in summer, as they have often seen that go thither crery year. But when the icc comes floating on too hard, or in too great a quantity, then the ships make to the harbours, havens, bays, or rivers, as they call them, that run up into the country; the wind useth to receive us something unkindly when we sail into them, roaring over the dry hills with small whirl-winds. The water in these rivers is salt.

We meet here with no fresh streams or rivulets; nor did I ever sce a spring there. Of some rivers we know their beginning, of others it cannot be found out, because of the danger of the ice, which they are never free from; some, because of the hidden rocks underneath the water, which are discovered by the vehement breaking of the sea, or by

1 This applies to the Reindeer, but not to the Artic fox and Aretic hare, which are constant inhabitants of the island. 
great quantity of white foam. The names of the havens you find all in order one after another in the map of Spitzbergen, as far as we have been.

'These harens they reckon to be the safest, viz., the Safe Harbour, and the South and North Bay, which are the most known of any in Spitzbergen.

The other havens, of what name soever, we commonly sail hy, because they lic open to the sea. Others we pass by bccause of the constant ice that is in them, and the hidden rocks.

In the South or North Haren or Bay, ride commonly the most ships; I told several times ten, twenty, nay thirty ships that lay at anchor.

Concerning the birds, we saw abundance more of them by and on the land than among the ice, chicfly when they hatch their eggs: we do not find they make up their nest with far fetcht things, ncither do they gather anything for them from Noruay, Schetland, or the like.

The sceds of several herbs might grow in Spitzlergen, but the herbs nature hath bestowed on those countries are such as are fit for the discases and distempers that are common there.

We saw abundance of sea-horses by Spitzbergen on the low land, and upon the ice; but we saw very few seales on the ice thercabout.

'I'he country (as is aforesaid) is stony, and quite throughout it are ligh mountains and rocks.

Below, at the feet of the mountains, stand the hills of ice very high, and reach to the tops of the mountains; the cliffs are filled up with snow, wherefore the snow mountains show very strange to those that never saw them before; they appear like dry trees with branches and twigs, and when the snow falleth upon them they get leares, as it were, which soon after melt, and others cone in the room of them.

'There are seven large Ice-mountains in a line in these 
countries, that lye between the high rocks, which look a glorious blew colour, as also is the ice, with a great many cracks and holes in them; they are hollowed out, melted away, and cut in grooves by the rain and snow water that runs down; they are encreased greatly by the snow, as the other ice that swimmeth in the sea is also: they are augmented likewise by the melted snow from the rocks, and from the rain that falls on them.

These seven mountains of ice are estcemed to be the highest in the country; indeed they shewed very high as we sailed by them underneath: the snow look'd dark from the shades of the skies, which shewed very neat and curious, with the blew cracks where the ice was broken off.

About the middle of the mountains some foggy clouds hovered over; above these the snow was very bright, the true rocks looked fiery, and the sun shin'd pale upon thom, the snow giving the air a bright reflection : they were covered with clouds, so that you could scarce see the tops of them.

Some of these rocks are but one stone from the bottom to the top, appearing like an old decayed wall; they smell very sweet, as the green fields do in our country in the spring when it rains.

These stones for the most part are vein'd differently, like marble, with red, white, and yellow: at the alteration of the weather the stones sweat, and by that means the snow is stained or coloured; and also if it raineth much, the water runs down by the rocks, and from thence the snow is tinged red.

On the foot of the mountains where no mounts of ice stand, lye great loose rocks, as they chance to be fallen one upon the other, with caves and holes, so that it is very ticklish walking upon them: both great and small stones or rocks are mixt together: these stones are of a grey colour, or grey with black veins, they glister like silver-oar. Most of the rocks that are at the bottom of the mounts are like the 
pebles we pave our streets withal. On these rocks grow all sorts of herbs, grasses, and moss very plentifully; they grow up in the two months of June and July, from the seed to bear seed again.

The herbs grow thickest where the water runs or falls down from the hills (and also where they are defended from the north and east winds), from whence always some dust or moss is carried down with it, which after a long time becomes carth (yet it is rathor dung than a true carth), and the birds do contribute by their dung towards it.

These mountains seem as if they were earth at top by reason of the height, but when you are at the top of them, they are rock as well at the top as at the bottom, which we also sce when great pieces of them fall down. If stones are flung down from these mountains, it sounds as if it thundred with an ccho and rattling in the valleys, as if very great pieces were thrown off from the top of them.

The mountains are also full of cracks, wherein the birds make their nests; they all fly down from the mountains to seek their food in the water ; some eat the carrion of fishes, others eat small fishes and shrimps, as I shall say when I treat of the birds. There are also white bears, deer, ${ }^{1}$ and foxes ${ }^{2}$ in thesc countries. 'I'he bear liveth upon dead whales or dead men, the fox feeds upon birds and their eggs, and the deer eat the herbs.

One may conjecture at the height of thesc mountains by this; when the skies are not very clear, the mountains stand to about the middle in the clouds; some of them look as if they were a coming down every moment.

The reason why the lowermost hills do not secm so high, is because so very great ones stand near them. A ship, with its mast and rigging, is no more to be compared with these mountains, than a small house with a high stcple. 'The

1 Reindeer (Rungifer Tarandus).

arctic fox (Cunis Lagopus. L.) 
miles seem also to be very short, but when you go to walk them upon the land, you find it quite another thing, and you will soon be tired; and also because of the roughness and sharpmess of the rocks, and for want of a path, you will soon get warm be it never so cold: a new pair of shoes will not last long here.

We went in the night, when it was very clear sunshine, upon one of the rocks near the English haven, about a mile long, to look after a whale that had got away from us : in the middlle of this harbour others were a rowing in their longboats, which we could hardly discern; a great part fell down from one of these mountains, which sounded very loud. 'The mountains look'd black, strip'd with reins of snow. It was so calm that we could hardly perceive any breeze of wind, and not very cold; the shoar was very full of secthorses, which roared so that we could hear them a great way off, as if some bulls had bellowed.

In the country we travel thus: we take along with us two or more guns and lances, to resist the highway-men the bears; but one is soon tired, as I said before, because of the stones and the loose ice, whereon it is very troublesome to walk.

As many as I have seen of these mountains are situated thus : the highest are from the Foreland to the Muscle Haren (or Muscle Bay), after the Forelund follow the seven Icemounts, which are very high mountains, and they are called so from the ice-hills that fill up the valleys, or lye between the rocks. These mountainous rocks are not so sharp or pointed at the top as the two foremost rocks at the Haven of Magdalen are. Then cometh the Haven of the Hamburgers, Magdalen, the English and Danish Harbour, and, at last, the South Haven. At the Magdalen Huven the rocks lye in a round or semicircle; at each side, by one another, stand two high mountains that are hollow within, as if they were dug out after the fashion of a breast-work, with points and cracks 
at the top, like battlements; at the bottom, within the hill, stands a snow-hill, that doth reach to the very top of the mountain, like a tree with branches and twigs; the other rocks look rudely.

In this South Haren the ships ride at anchor, between high mountains; on the left as we sail into it is a hill, called the Beehive; called so from its resemblance to a bechive; close to it lieth a large and high mount, called the Devil's Huck, commonly covered with a fogg, and if the wind bloweth over it, it darkeneth the haven, and seemeth as if it smoaked, filling the haven therewith : on the top thereof are three small white hills covered with snow, two of them stand near to one another. In the middle of this harbour is an island, which is called the Deadman's Island, because they bury the dead men there after this manner: they are put into a coffin, and covered with a heap of large stones, and notwithstanding all this they are sometimes eaten by the white bears.

I have seen 110 other sort of ground but great stones at Spitzbergen, so that the frost cannot penetrate far into such ground. I admired that the snow was at that time all melted away, and in the cliffs between the great rocks was no more snow to be seen, although the holes werc very deep. I fancy that abundance of rain had fallen in the spring, and that the weather had been tolerable, or else we must have seen more snow there.

There are also more small islands here and there in this harbour, that have no particular names, but are called Birds' Islunds, because we gather thereupon the eggs of mountain ducks and kirmeums. ${ }^{1}$

'Then you come to Schmeremburg, so named from schmer, which signifieth grease; there are still houses standing, formerly built by the Dutch, where they used to boil their

1"Kirmenen," a species of gull (Latrus) or tern ( Nberiue). 
train-oil. Some Dutehmen onec attempted to stay there all the winter, but they all perisht.

It is obscrvable that a dead carkase doth not easily rot or consume; for it has been found, that a man buried ten years before, still remained in his perfect shape and dress, and they could sec by the cross that was stuck upon his grave, how long he had becn buried; these houses are now from rear to year destroyed and burnt. This ycar were yet standing scrcral houses, like a little village, some whercof were then burnt.

Over against Schmeremburg were also several houses standing, and a kettle or boyler; they call that place the Cookery of Harlem. This year four houses remained, whereof two were warehouses, in the other's they dwelt: they are built after this fashion, not very large: there is a stove before with a ceiling at top, and behind a chamber taking in the whole breadth of the house: the warehouses are somcthing larger; therein were still several barrels or kardels that were quite decayed, the ice standing in the same shape the vessels had been made of. An anvile, smith's tongs, and other tools belonging to the cookery, were frozen up in the ice. The kettle was still standing as it was set, and the wooden tronghs stood by it. From thence you may go to the English-Haven; on the other side is the place where the dead are buried; this is something even, like earth, but it is levelled on purpose. Behind these houses are high mountains; if onc climbeth upon these, as we do on others, and doth not mark every step with chalk, one doth not know how to get down again. When you go up you think it to be very easie to be down; but when you descend it is very difficult and dangerous, so that many have fallen and lost their lives.

The river there is called the South Harbour, or Bay; and if the ships suffer any damage at the sca they refit there.

At the entry into the South Harbour, in the valley between the mountains, is collected great quantities of fresh water 
from the snow and rain; upon the shoar stand abundance of kardels or barrels; we use this water for our victuals, and other occasions. It is also found in the clifts of the icy-hills on shoar, but true springs out of the ground I never saw in Spitzlergen.

The shoar there is not very high, but the water is deep; there was no ice at all to be seen in it, from whence I conclude that it had not been a severe winter; for it is impossible that the ice could have been melted in so short a time, not only here, but also in the English Haten or Buy, where the ice stood firm still, and hardly lay above half a fathom under water.

The ice doth melt much sooner in salt water than in fresh river water, but yet it is impossible that so thick ice could have melted in so short a time. We saw also that the snow melted on the tops of the high rocks, and the water ran down, although it was there much colder than below; yet above and below it melted alike, differently from what I observ'd since in Spain in the month of December 16r:, the wind being north-west, when the rain fell below about a quarter of a league, yet above it the mountains were all covered with snow, all in the streight line, one not higher than the other, as if they had been levell'd.

In the Northern Bay or Haren lyeth a very large mountain, flat at top; this island is called the Bird's Song, from the great number of them that build and hatch there: for when they fly up, they make so great a noise, that one can lardly hear his own words.

Besides these, there are more islands named in the map, as the Clifted Rock, and such other.

The Rehenfeld is a low land, and it is called so from the decr commonly seen there.

I was informed that it is all slats, that stand up edgewise, so that it is very troublesome to go on: it is all orergrown with moss. 'There is a hill upon it that looketh like fire. 
Behind the Rehenfeld are high mountains again, they are not pointed at top, they lye as it were in a line; by the Rehenfeld runs up a river into the country, it is called the Half-moon Bay from its shape. On the other side of the river is a mountain, flat at the top, and full of cracks all filled up with snow. 'T'hen cometh the Liefde Bay (Bay of Love), where two hills stand together very like unto Spitzbergen at Magdalens Bay, and those two harbours are very much like one another.

Then we come to the lower ground behind the Muscleharbour, where the grass was so high that it corered our ankles as far as we went.

Next is the Weighatt, or the Straights of Hindelopen. The Weighatt is so called from the winds (for weihen signifieth bloxing), because a rery strong south wind bloweth out of it. On the Bear Haven, upon the land, are all red stones.

Behind the Weighatt followeth the South-uest Land, which is also low; it seemeth as if it was adorned with small hills; then follow the seren Islands which we could see.

We saw no ships go any farther, neither could I understand that ever any ships did go farther, nor can they go so far every year towards the east, because of the danger of the ice that swimmeth, and is brought from thence by the wind and stream.

In May and June is the best fishing in the ice between the Island of John Mayen and Spitzbergen. In July and August the whales run eastward by Spitzbergen, we saw at the latter end many whales that run to the IVeigatt. It is unknown whether the haven of this Weigati goeth through the country or no. But this is not that Weigatt whereof so many things are written. ${ }^{1}$

More I do not know of this country; rocks and snow and ice-hills we find in abundance there, and the creatures that live upon them I shall describe hercafter.

1 The "Weigatt whereof so many things are written," is the strait separating Nora Zembla from the continent. See Gerrit de Teer's "Three Toyages by the North-East," edited for the IIakluyt Suciety by Dr. Beke (jassim). 


\section{CHAPTER II.}

Of the Sea.

THE waves begin to raise themselves at first from a small breeze of wind, and by the increase and continuance of the brecze they grow longer, higher, and bigger.

The sea is not immediately made rough in the beginning of high winds, but the waves swell by degrees and slowly, until they come to be as bigg as mountains; then they expand and break themselves, and fall over with dashing.

Then the following wave from behind raiseth it again with much curled and foaming scum, neatly spotted with the white foam, looking like marble. This breaking and foaming of the waves is successively repeated.

So the swelling waves continually follow one another, moving before the wind with a quick motion; but when these wares are short, they dash over the ship and break much, so that the ship is hardly able to live.

In stormy weather little waves curl upon the top of the great ones, and lesser again upon them.

'The ships do not feel these smaller waves, but only the great ones, that are called sea-mountains, which heave and mount the ship with them, but nevertheless she always keeps her straight way through these unpathed waves, which is wonderful to behold.

In a hard storm the froth of the sea drives like dust, and looked as when the wind driveth the snow along upon the ice, or as the dust of the earth does in dry weather, and you see the sea everywhere to look like curled ice, that when it is freezing is hindred from it by the wind, all covered with a white foam, and one wave blows over the precelent, with 
a great roaring and noise, as if a watermill were agoing; and this same noise the ships make likewise when they eut through the sea.

It is also to be observed, that the waves dash against one another when the wind changeth, and cross over through one another, with great dashing over the ships, before they more all one and the same way.

I did not observe here the sea water so clear, nor found it so salt as near the ice; it may be by reason of the shallow ground or bottom, and the many fresh rivers that now run into it, or because the frost cleareth the water more.

Concerning the manner of their sailing, they sail and change their ways and sails according as they think fit. If there be a fresh gale, they make use of all their sails; whereof they call the first the fock or foresail, the midcllemost schumfer or mainsail, and the third the basan or mizensail.

In hard storms they furl the foresail, and sail with only mainsail and mizensail. In the greatest storm of all, with these sails reefed or half tied in, as they call it, or with the mizensail half furled up; this they do because the ship goeth the stedier by reason of the wind, or else it would rowle too much up and down in the sea, and the water would dash in too much on the sides thereof.

One man stands always at the helm to steer the ship, but in hard weather ten men can hardly hold the helm, wherefore they fasten it with a tackle, and so let it go to and fro as the compass directs them.

In and after a storm we have oftentimes strangers come to visit us in our ships, viz., blacklirds, starlings, and all sorts of small birds, that have lost their way in a storm from the land, and fly to the ships to save themselves and prolong their lives, when others fly about till they are spent, and then fall into the sea and are drowned.

'The lumbs and other water-fowl come not near us, which 
I mention on purpose to confute the erroneous opinions of some, that believe that the before-mentioned birds come to the ships as messengers, to bring the ill news of bad weather.

Yet notwithstanding, these following signs or marks commonly fortell a storm or hard weather: when great fish come near to the ships in great numbers, when they play, dance, rowl about, and leap out of the water, which is not always playing in them, but rather their bodies are afflicted with some pain or other. We saw several whales in the sea that threw themselves about as if they were sick or dying.

When the sea is tempestuous, it is not to be thought that it doth proceed from the sea only, but a hard and tempestuous storm and wind followeth upon it, that sendeth the waves like messengers before it, until it arriveth itself with a tempest; but this is not to be understood of the North Sea, but only of the sea betwixt Hitland and Spitzbergen.

When the air is so disposed, as the stars do not only look bigger, but as if they were more in number also, it is a great prognostication, and often proveth true also; it is a sign that the air is full of mist, which causeth, upon changing of the frost, great foggs, and a high wind follows soon after.

At night, when the sea dasheth very much, it shines like fire; the seamen call it burning. This shining is a very bright glanee, like unto the lustre of a diamond.

But when the sea shines velnemently in a dark night and burns, a south or west wind followeth after it.

At the stern of the ship where the water is cut throngh, you see at night, very deep under water, bubbles rise and break, then this shining or lustre is not there.

Hitherto we have discoursed of the North Sca, but next of the waves between IItlend and Spitzbergen; near Mitland the stream rumeth very swift towarls the north, and it grows diiily colder. 
It is to be observed that here the waves of the sea run longer, almost as they do before the narrow channel between England and France in the Spanish Sea (and what hath been observed heretofore of the rowling and tossing of the sea, belongeth properly to this), with a continual tossing of the ships, which maketh the men sea-sick.

The romiting and sickness is attributed to the sea water; but it really proceedeth from the great and continual motion of the body, when oftentimes we are forced to creep on all four.

Neither meat"nor drink tasts well, the head akes and is giddy, and they are always reaching to vomit. Costiveness of the body doth generally accompany this distemper, and the urine is highly tinged. I reckon it no more than if one is not used to ride in coaches or waggons; only that it is always accompanied by a bad stomach and restlessness.

The best remedies for this distemper, I believe, are aromatics chewed in ones mouth, as cinnamon, cloves, galengal, ginger, nutmegs, and the like. Many think to drive this distemper away with fasting, but they will find themselves mistaken. Some drink sea-water, and believe that will make them romit, which notwithstanding is not occasioned by the sea-water, but by the loathsomeness thereof.

'lo take away the ill-taste out of ones mouth, in my opinion, the best means is to eat and drink plentifully, it easeth quickly; neither ought one to sleep too much, but keep in the air, and look into the wind, and to walk up and down in the ship is also very proper.

But now let us return to the waves again: they rise, although it be not windy, as high as mountains, very smooth, and run away as far as one can discern them, which is to be understood when the sea is turbulent, whereupon quickly a hard gale of wind followeth. In a storm the waves run after the same manner as is just now said, but with many curling and foaming whirls, as is described in the storm of the North 
Sea. 'These waves run a great way, so that you may see between them at a great distance.

If any ships bc in your company, oftentimes you cannot see them.

These waves are a great deal larger than in the North Sea, and have also greater power when they fall over, but do not dash so easily over the ships as they do in the North Sea.

'The waves in the North Sea are presently lay'd after a storm, but the commotion of these lasteth often to the third day; if it be never so calm, the ships are moved very violently, that you cannot walk, sit, or lie ; it is best to keep in the middle of the ship, for bcfore and behind the sea beats hard against them. The sails are driven against the masts, and have no steadiness from the wind. If, in a brisk gale of a full wind, the sails are all full and round, the ship sails best upon the sea.

There is as great difference in ships as to sailing, as there is in horses concerning easiness and swiftness; the motion of the ships is therefore different: the stilness and quietness, when nothing is tumbled up and down in the ship, furthering also the sailing very much.

The ships swim something higher in the sea than they do in fresh water, for there is almost a foot difference in a ship with the same loading. 'T'is generally agreed upon, that one may sec a ship in a calm sea three, or three and a half German miles off, and beyond that distance the sea loseth itself in the air, and the air in the sea. If a ship saileth on the main sea at one and a half German miles' distance, you have lost the sight of half the ship; at two miles, you see only the uppermost mast; at three miles, you see only the flagg; and when it goeth farther, you have quite lost it. Land and mountains may be seen at a great distance at sea; we saw Spitzbergen at twelve miles' distance off at sea ; the country look'd like a black cloud full of white stroaks. Near the ice of this sea it is coldest where the waves are quiet, and the 
sea-water so clear, that at twelve and more fathoms deep yon may see the bottom. There is no ground to be found near the ice to drop an anchor.

It is also to be observed, that according to the colour of the skies the colour of the sea is changed. If the skies be clear, the sea looks as blew as saphire: if it is corered somewhat with clouds, the sea is as grcen as an emerald; if there be a foggy sumshine, it looketh yellow; if it be quite dark, like unto the colour of Inclico; in stormy and cloudy weather, like black sope, or exactly like unto the colour of blacklead.

If the wind be quite calm, one may hear beating or knocking at a great clistance on the sea, by which we also observe the whale hears, as shall be mentioned in its proper place.

Among the ice the strcam runs southwards, which we observed by our driving back a great way. At the Muscle Hacen the stream ran northwards. Those that sail yearly to those places cannot give any certain information concerning ebbing and flowing; only they have observed the water to be higher about the land, when the winds have been higher, than at other times. And this I have also observed, that if there was an orderly or continual ebbing and flowing, the eggs of the birds would be drowned upon the islands.

Certain information concerning ebbing and flowing is not easily to be had; I know no more of it then what I have written. 


\section{CHAP'TER III.}

Of the Ice.

In the months of April and May, the west ice breaks, because it lyeth westward, which drives dispersed in the sea, by the Island of John Mayen, and reacheth to Spitzbergen, where at that time it was firm still.

The difference between the ice of Spitzbergen and that of our country is, that it is not smooth there, so as to slide upon it.

Neither is it so clear nor transparent, nor so sharp and cutting, but a great deal harder, and is not easily broke or split; but it looketh likest unto the ground-ice of the rivers in our country, or like unto loaf-sugar.

Where the ice is fixed upon the sea, you see a snow-white brightness in the skies, as if the sun shined $;^{1}$ for the snow is reflected by the air, just as a fire by night is; but at a distance you see the air blew or blackish: where there is many small ice-fields, that are as meadows for the seales, you see no lustre or brightness of the skies.

The sea dasheth against these ice-fields, which occasioneth several fine figures; not that they are naturally framed so, but just as ice-flowers on our glass-windows get all sorts of figures: for these are framed by the dashing of the sea, like unto mountains, stceples, chappels, tables, and all sorts of beasts.

'These ice-fields are a great deal deeper under water than they are high above it, and are of a paler colour under water than above; the top of them might be called the kernel and marrow of the ice, because the colour is much decper than that of the other.

1 This is called "Ice-blink" by whalers and Aretic voyagers. 
The highest colour is delicate blew, of the same colour with the blewest vitriol, somewhat more transparent, yet not so clear as that in our conntry, which you may sec through let it be nerer so thick; it is as hard as a stone, and it is not easily split or cleav'd, because it is spungy, like unto pumice stone. Among the ice the ships sail up and down until they come to bigger ice-fields, for the small ones cncumber the sea, that the ships sail often against them and perish; for when the winds arise the waves drive against the ice-fields, as it was against rocks, and beat the ships to picces.

When we are passed by these small ice-fields, that swim at a great distance from one another, then we sail in betwecn them and draw a small ice-field behind the stern of our ship, that it may be the sooner stopt and kept from swift sailing without letting the sails strike, or else it might easily run against an icc-field. Erery ship's master is left to his frec will whether he will sail into the ice, becanse in the spring the whales are in great numbers seen there in the West-ice, as they call it.

The masters do not willingly sail in amongst the ice when it is dark or foggy or stormy, which must be expected in the spring, and the small sheets of ice swim up and down in the sea, which the skippers must avoid lest they lose their ships.

It may scem something strange that they sail so often to the ice and back again, but there is the same reason for it as hunting after deer, if we do not find whales in one place, we must seek them in others; for the fortune in ketching of whales is like the chances of gaming, and there is no great understanding required to find them: some sec and catch more than they desirc, and others but at a half mile distance from them see not one, which is very common.

When they go in among the ice, the men stand ready with great icc-hooks to keep them off, that the ship may not rum against them.

The farther you sail into and amongst the ice, the greater 
icc-ficlds you shall sce; so that you cannot look orer them; for about the west, as they call it, are larger ice-ficlds to be secn than about Spitzbergen, quite white at the top, covered with snow, so that there is but ill walking upon them, because you fall decp in the snow.

The prints of the bears footing we saw on the shoar of the icc-fields, for they seek their prey in the water, which is the dead carkases of the whales; the foxes generally accompany them, for their choicer food of birds is here scarcer than at Spitzbergen, for they flock not together, but fly singly.

When they sail some miles into the ice, where there is pretty large ice-fields, they joyn their ships to them with great ice-hooks, fastened to strong cables, where they lie at anchor, several ships about the same ice-field, but they rather chose to be alone, because they are an hindrance to one another in whale-catching, and the hunting of them one to another makcth them shic.

Amongst the ice we find no great waves, but it is pretty smooth, eren when it is somewhat stormy. All the danger is from one icc-ficld being bigger than the other, and the little ones swiming faster than the great ones, which often causeth a stoppage, so that they crowd upon one another, not without great danger of the ships, which arc often catcht between, and broken by them.

The seamen hinder the pressing on of the ice, as much as in them lieth, with great ice-hooks; but what small help this affordeth them daily experience testifies sufficiently. In fair weather the mischicf is as soon done as in tempestnous, because the ice drives in the sea either with the stream or wind, as either of them is the more prevalent, crashing and grinding against each other, whence the danger arises to the ships, for after such a manner many ships perish.

They say that a dead whale, tied to the ship, is the best defence against the ice. Others hang the tails and fins about their ship, which way is not to be rejected, for it is of great 
use to them to prevent the danger of the squeczing of the ice; they have cxamples, that in such squeezing of the ice a dead whule hath preserved them.

The ice rises ont of the sea as high as a mountain; the striking of them together makes so great a noisc, that one can hardly hear his own words; and from this joyning together of the ice the great ice-hills are made, that drive up and down in the sea.

Other great ice-fields are not so high as the ice-hills, yet notwithstanding they are hardly ever quite plain and without a hill; you see the ice under water as deep as you can see. It is all of a blew colour, but the deeper you look the purer a blew you see; which beantiful colour changes with the air, for if it be rainy weather this colour groweth palcr. I also have often seen the ice under the water very green, the occasion thereof was the troubled air, whence the sea assumeth this colour.

I wonder that upon the largest ice-fields no high mountains are seen, as are seen where the ice grinds and dashes one against the other.

I am of opinion, that the ice melts towards the bottoms, for one may see it spungy, for else if one would compute from the beginning, it must have reached the rery ground even in the middle of the depth of the sea. I have seen in Spitzbergen white ice that was frozen quite curled, it look'd just like sugar-candy, was very hard and thick, and swam even with the seas surface. The ships are not always in this danger of squeezing, for oftentimes there is little or no ice to be seen there, although you are a great way in the place where it usually is; but as soon as a wind arises, you would admire from whence so great a quantity of ice should come in less than an hour's time.

At the greatest ice-fields of all, ships do not always ricle the safest; since by reason of the bigness and motion of the sea, these iceficlds break not without danger. 
When such ice-fields break they part asunder, which causeth a whirlpool in the sea, where all the out-parts press to the centre, and by that means the pieces of the ice-fields raise themselves up, and dash and grind themselves against cach otlier.

When we came to seventy-one degrees in the month of April, we saw first the ice, and so we sailed up and down by the ice until that month was spent, for so early in the year nobody dares venture himself into or amongst the ice, by reason of the stormy winds; and sometimes the ice is still fixed and stands firm, and therefore there is but a few whales seen, for underneath the ice they cannot breathe.

Into the ice we sailed at seventy-seven degrees and twentyfour minutes, and drove with that sheet of ice towards the south. In this month, and also in the following month of May, are the most whales seen here, which run towards the cast, and we follow them all along by the ice to Spitzbergen.

Near to the land smaller ice-fields are seen, because the ice cannot give way by reason of the land, which causeth greater grinding and breaking, and upon that account smaller ice than is in the open sea. Yet, for all this, some greater ice mountiins are seen there that stand firm on the shoar, and never melt at bottom, but increase every year higher and higher, by reason of the snow that falls on them, and then rain freezes, and then snow again alternately; and after this mamer the icy-hills increase yearly, and are never melted by the heat of the sum at the top.

These ice mounts change their first colour in time by the air, by rain, and by the clouds; and the fairest blew that can be secn is in the cracks of these ice-hills. From these same ice-hills oftentimes break off great pieces, that swim in the sea, and is more compact than the other ice by far. I once saw one of these pieces that was curiously worked and carved, as it were, by the sea, like a church with arehed windows and pillars, the doors and windows hung full of 
icikles; on the inside thereof I saw the delicatest blew that can be imagined; it was bigger than our ship, and somewhat ligher than our stern, but how deep it was under water I camnot exactly tell. Near unto the Muscle-haren, a great ice-hill came driving towards our ship, that was as high as our poop, and went so deep under water that it took up our anchor, which lay fifteen fathoms deep.

I have also seen several others, and of other figures, viz., round and four square tables, with round and blew pillars underneath: the tables was very plain and smooth at the top, and white with the snow; at the sides hung down a great many icikles close to one another, like a fringed table cloth; I believe that near forty men might have sat about it. I have seen of tables these with one foot, and with two or three pillars, and abundance of seales swarm about. The dishes that furnisht this table, were a piece of ice like an horse's head, and a swan; I doubt they were but salt. Tou must observe that this ice becometh very spungy by the dashing of the sea, and from thence grows salt, like seawater, and thence also changeth its colour, viz., from the sea and rain-water mix'd with it; for you shall commonly see the water look blew or yellow, if you walk under water with your eyes open and look upwards.

The other ice, as far as it is above water, is of a taste like other ice, but that below the sca, salt, like the sea-water.

When we arrived at Sprtaberyon, the ice at Rehenfelt was as yet fixed, but a few days afterwards it was driven away by the winds.

'The ice begirts these comntries on all sides; as the wind sets either from the Island of Johu Mayen, Old Greenland, and Nora Zembla. We found at this time that the ice reached from the other side of $S_{1}$ ilizbergen, and the ships sailed between the ice and the land as if it were in a river.

As soon as this ice is drove thither by the winds, the ships must give way or go into the harbour, until the winds have 
blown or driven the ice away, or else they are lost; but if there be other ships that escape, the men are saved.

On this ice I did not see many sea-hounds, but a great many sea-horses, and many birds and forls.

We sailed still on till we saw the Seren Islands, but could go no farther.

\section{CHAP'TER IV.}

Of the Air.

'IHE frost is unconstant in our country, but it is not so in Spitzlergen. In the month of April at seventy-one degrees, it was so cold that we could hardly keep warnth within us. 'They say that in this month as also in May, the hardest frosts happen every year.

All the rigging, by reason of its being wet, is coverecl over with ice, and stiff.

'They do not send their ships so soon as they did a few years ago, and yet they come time enough there, for if they arrive too early, there is nothing for them to do, because the ice is not yet dissipated, and therefore but few whales to be secn.

In the two first summer months of Spitzbergen, their tecth chatter in their heads commonly, and the appetite is greater than in any other countreys.

'The sum sets no more after the third day of May, and we were about seventy-one degrees, when we could sec as well by night as by day. I camnot say much of constancy of the weather in these two first months, for it changed daily; they saly also, if the moon appears cloudy and misty, with a streaky 
sky, that then there commonly follows a storm. Whether the moon doth prognosticate such storms, I cannot tell, because we have observed, that after we have seen the moon, in a clear sky, the air has grown foggy, which happeneth often, chicfly if the wind changes. When the hills show fiery, it is from fogs, which after spread themselves everywhere, and the cold increaseth: these foggs looks blew, like Indico, and black afar off, which upon changing of the weather are driven along by the wind, so that in less than half an hour, the sca is so covered with thick fogg, that you can hardly see from one end of the ship to the other.

On the 1fth of May the air was bright and clear, and yet very cold; we could see the whales farther off in the sca, than usually at this time. We could not distinguish the air from the sea, for it shewed as if the ships danced in the air like naked trees or poles.

After the same manner Spitzbergen looks at a distance like a cloud; the momntains are so reflected by the sea, that he that knows not the country very well, camnot easily discern it from air, and so other countries very often appear.

The other three months, June, July, and August wore very calm.

Concerning the cold, it is nuch according to the quality of the winds; so north and east winds cause very intense frosts, so that one can hardly keep alive, especially if the wind blows hard.

West and south winds, when somewhat constant, cause much snow, sometimes rain also, and moderate cold.

The other winds of the thirty-two according to the compass, whatever names they have, are changed by the clouds, so that sometimes when the wind was south-rrest and by south in one place, at a few miles distance there blows quite another wind.

What heat the sun oftentimes affords we saw by our eyes watcring, and the tears that ran continually down our checks. 
Yet this severe cold is not always, as is alrcady mentioned ; for if it were, how could any herbs grow there.

Neither is there every year a constancy of winds or weather ruled by the moon, but an alteration, as in other places, sometimes a milder, and sometimes a scverer, winter.

Skilful ship-masters and harpooners commend those years for uhale catching that have not many foggy and cloudy days. Whether, according to the new and full moons, the springticles happen, cannot be known.

Such clear slies as we have sometimes in a summer's day, with pleasant curled clouds, I have not seen at Spitzbergen; but, on the contrary, several dark and foggy ones. Rising thunder-clouds I have not seen, nor ever heard of anybody that had seen them.

Above the ice the air appears white, from whence we know where the firm or fixed ice lies, as I have before observed in the chapter on ice.

In the two last summer months, chicfly in July, before the IV eigatl, the sun shin'd so warm that the tarr of the ship, bctween the seames, whore the wind could not come at it, melted.

'There is hardly any difference of cold between night and day, yet at night, when the sun shineth, it seemeth to one that rightly considereth it, as if it was only clear moonlight, so that you may look upon the sun as well as you can upon the moon; so that thereby one may distinguish night and day from each other. Inerease of cold, and changing of the compass, we did not observe as far as we went. It is also to be observed that the frost does not let a dead body be consumed easily in the ground, as is already obscrved in the chapter of the description of Spitzbergen.

'The Ind day of August, in our royage homeward, we observed the sun first to set.

Concerning the metcors generated in the air, I observed the rime fell down, in the shape of small needles of snow, into 
the sea, and covered it as if it was sprinkled all over with dust. These small needles increased more and more, and lay as they fell, cross one over the other, and look'd very like a cobweb; they are formed by the cold of the air, and increase to that degree that the sea seemed covered by them as with a skin, or a tender ice, which had the taste of fresh water; as also the sea water that is taken up into the high air is changed, and falleth down again in sweet or fresh rain.

This hapneth in elear sunshine and intense cold weather, and it falleth down as the dew doth with us, at night, invisibly, in dull weather; when the sun doth not shine, you cannot see this, but you see it plainly if you look when the sun shines towards a shady place, for then it sparkles as bright as diamonds, shows like the atoms in sunshine; all day long it falleth in so small particles that nothing sticks or hangs on your cloaths of it to make them wet. At noon, when the sun shines very warm, these small needles melt in the air and fall down insensibly, like dew.

Sometimes we see, in our country, something a little like these small needles, which is what we call rime, and falleth from the trees in atoms, like dust. This is small snow, and may be seen as well in the shade as in the sun. 'These needles are not the exhalation or vapour that uses in cold weather to stick to the hair of men and beasts. I must not forget that we see in these falling needles a bow, like a rainbow, of two colours, white and a pale yellow, like the sun reflected by dark shadows of the clouds.

After this, I proceed to the description of another bow, which I eall a sea-bow. This is seen when the sun shines clear and bright, not in the great waves, but in the atmosphere of the sea-water, which the wind blows up, and which looks like a fog. Commonly we see this before the ship, and sometimes also behind, to the lee-ward (so they call that side of the ship toward the sca), over against the sun, where the shadow of the sail falleth. It is not the shadow of the sail, 
but a bow, showeth itself in the shadow of the sail. We see this pleasant reflexion in the small drops of the salt water, in sercral colours, like the rain-bows in the skies, that are scen over against the dark clouds.

'This brings to my mind another phænomenon, viz., that in the clouds near the sun a very bright light is seen, like a parelion or mock-sun. 'These lights are called Weathergalls by the sea-men.

This bright light we find in the lowermost air, in the dark shady clouds, that are not unlike to a clourl of rain, because it is full of drops, wherein the sun is represented, as things are in a looking-glass.

'Ihis clearness of the sun causeth a heat, which drives from it a rainbow, figured by the sun, which bow are the drops that by the heat of the sun are changed into a vapour or fog ; and this vapour shews like smoak in the air, when the cold remits, wherein these colours are no more seen.

But in these raised drops, as aforesaid, the sun represents itself, and causeth these colours, which are truly distinct, and represent blew, yellow, and red, which are the three primary colours of the bow.

Concerning the bigness thereof, I did consider and minded the bow that I saw in Spitzbergen, and found that it moved about with the sun by day and by night, and that it appeared much bigger in the morning, evening, and at night, than in the day-time.

I will not mention the whirlwinds, which are unknown in these cold countries, that used to take up the water into the air; but yet I will not omit the small whirlwinds that proceed from the high mountains, from whence the wind recoils, and so turneth round about.

We see, farther in Spitzbergen, that the sea, as well as other waters, sends fortl a vapour when the cold encreases, which vapour is turned into rain in the air, or into snow, and it smelleth like a fog or steaming water. 
It is likewise an observation there, that when we see great rapours or fogs in the air, and that such a vapour risctil almost every moment, in a clear sunshiny day, without wind or other causes, the cold weather is about to remit; but when the air is overburdened by these vapours the clouds are dissipated, and they last a great while, with constant wind. Such vapours as we see in the air stick to our cloaths and hair like sweat.

Out of these small vapourous drops the snow is first generated. First of all you sec a small drop, as big as a single sand. This is augmented or increased by the fog, until it cometh to be like unto a shield or plate, with six corners, as clear and transparent as glass; to these six corners sticks the fog like drops; then it freezes and splits asunder, so that you see the figure of a star, which yet is still frozen together, until in time it is quite parted or divided asunder one from the other; and then you see a star with six points, which points are not yet quite frozen, because there are still hanging some wet drops between the points; mntil it at length assumes the perfect form of a star, with points serrated at the sides, like ferne, on the points whereof still hang some drops, as you sce at $\mathrm{E}$, which are lost at last; and so it is turned into an exact and perfect star, and this is the formation of the snowy star, which is seen in the scverest frosts so long until at last it looseth all its points. As to the many sorts of snow that fall in spitzbergen, and in what weather, I have made these following observations and distinctions. Fig. 1, in the plate, showeth the snow that falleth when it is tolerably cold and rainy withal; then it falls like muto snall roses, needles, and small corms: when the cold weather doth remit, the snow falleth like stars, with many points, like the leaves of ferne (fig. 2.) If it be only a fog, and it snoweth much, it looketh as you see fig. 3 ; if it is rery cold and windy, like fig. 4 ; when it is very cold, and not wincly withal, the snow falleth like stars, in a cluster, 
because the wind cannot blow them asunder, like fig. 5 . When the wind was north-west, or the skies were thick of clouds, and it was stormy withal, there fell hail that was round and oblong, all over full of prickles, and of the same bigness you see it at fig. 6 .

There is many sorts of starry snow to be seen, with more points, and some like unto a heart; but they are all generated after the same manner, by the eastern and northern winds. The needly snow is generated by westerly and southerly winds. If the snow is not dispersed by the wind, it falleth down in clusters.

But when the wind driveth it, stars or needles only fall, erery piece by itself, like the atoms in the sun.

This much have I observed hitherto of the snow, and find also that when it is cold, and a north wind blows, all sorts of snow, both starry and of other shapes, fall as well in these countries as in Spitzlergen.

TIIE EXD OF THE SECONI PART. 
1111 1

. 3
11111
* * ${ }^{2} *^{*} *^{*} *$

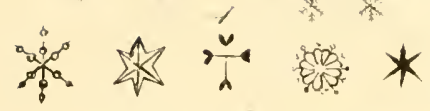

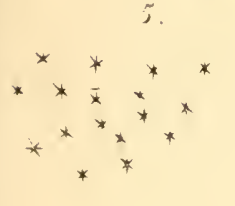

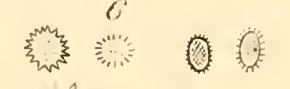

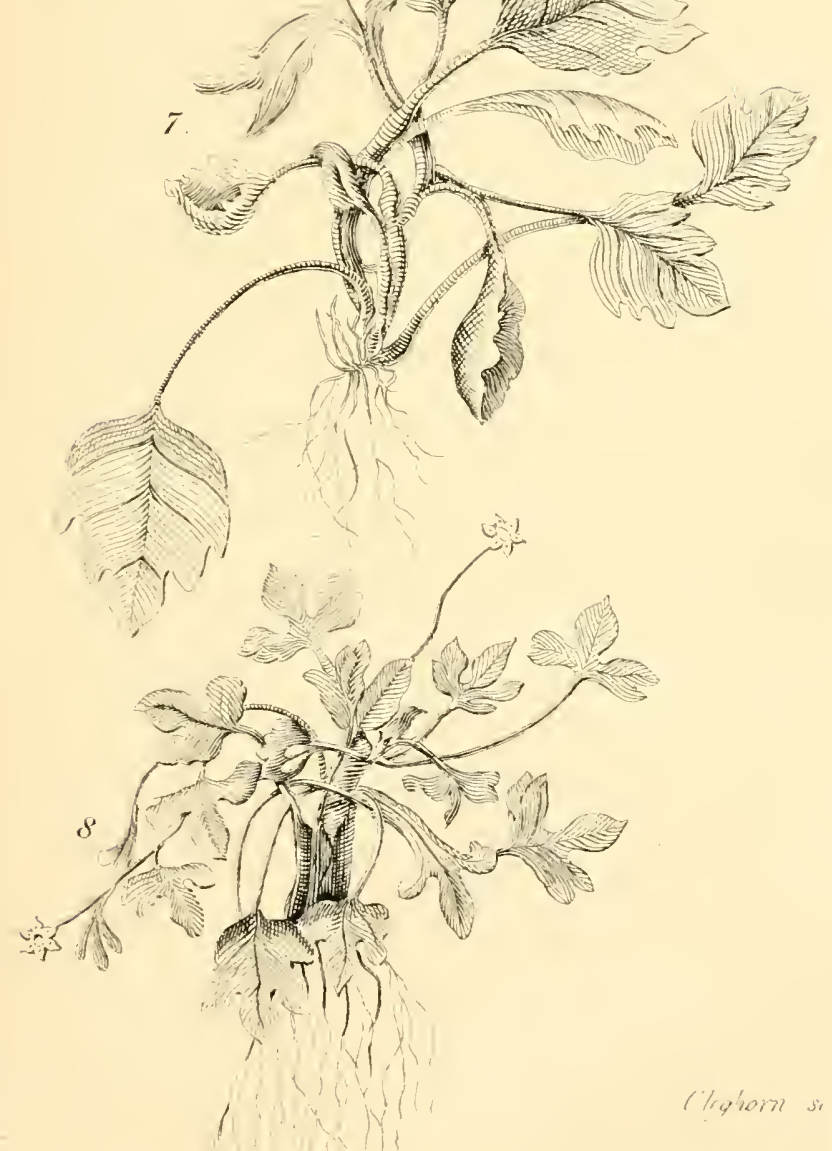




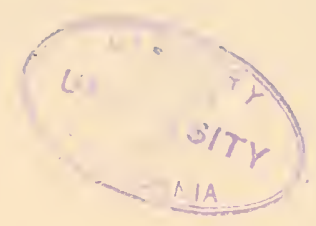




\title{
PART THE THIRD.
}

\author{
CHAP. I. \\ Of the Plants of Spitzbergen.
}

Gexerally the figures of the plants I here present you with, were all drawn by the life, upon the place, when they were fresh and of their natural size, except the rock-plant with but one leaf, and the plant like horse-tail, that stands by it, which, because of their largeness, could not be well drawn so big as the life. All the herbs and mosses grow upon the grit and sand of the stones, where the water falleth down, and on that side of the hill which the east and north winds cannot easily come at. The plants owe much of their growth to the dung of the birds.

There were a great many small herbs, which for want of time I could not delineate, but I propose to do it hereafter, if God blesseth me with life and health when I make my second voyage thither.

I omitted the white poppy, whereof we stuck the flowers in our hats; the whole plant was abont a span long.

Besides I have not mentioned the red sorrel, I mean that which was shewed to me at Bremen by the Dutch gardener, which was of the same size, but the leaves of that of Spitzbergen are red.

I desire the courteous reader to accept at present of these for a sample, to show him that on these rough, barren, and

1 The author here refers to the numerous illustrations given in the original work, nost of which it has been deemed unnecessary to reproduce, 
cold mountains, there yet grow some plants for the nourishment both of man and beast. The herbs grow to their perfection in a short time, for in June, when we first arrived at Spitzbergen, we saw but very little green, and yet in July most of them were in flower, and some of them had their sceds already ripe, whence we may observe the length of their summcr. I proceed to the description of those plants which I had time to delineate, and begin with those that put forth their leaves only at and about their roots, and have but few or no leaves on their stalks.

Then shall follow those that have single leaves on their stalks, then those that have pairs of leaves or opposite ones, afterwards those with three leaves, and then conclude with the imperfect plants.

\section{CHAP. II. \\ of a Plant with Aloc-Leaves. ${ }^{1}$}

IT is a very pretty herb, and puts forth thick prickly and sad green leaves, like those of aloes; a brown naked stalk, abont half the length of your finger, whereon hang round heads of flesh-coloured flowers in bunches, which are hardly to be discerned by the naked eye, one flower close above another, and near to another.

Sometimes two stalks shoot out of one plant, one bigger than the other. Iet each stalk has two of these bunches of flowers.

I could not delineate its seed for want of time. 'The root consists of many small fibres. We gathered it in great plenty on the 17th of July, bchind the cookery of Harlem, in the running water. I know not well to what kind this

1 This seems to be Suxifraga tricuspidate (see Appendix). 
may be referred. Caspar Bauhin maketh mention of an herb in his Prodromus of his Amphitheater of plants in the 5th book and 15th chapter, which he calls Limonium Maritimum, which he describeth with small, roundish, and thick leaves, like house-leek, between which spread small stalks with pale red flowers; but the root doth not agree with our plant, for his is long, red and parted at top, whereas this root consists in many small fibers, and is not red.

\section{CHAP. III.}

\section{Of small House-Leek. ${ }^{\mathrm{I}}$}

'Trin leaves of this are indented and very like those of our dasies, for which I should have taken it also, had it not been for the flower, only the leaves are thicker and more juicy, like those of house-leek, or as we call it, those of the lesser house-leek: the leaves grow round about the root, betwixt them is a small stalk of the length of your little finger, which is round and hairy, and generally without leaves, save only where it divides into another stalk, at which place is a small leaf.

'The flowers grow in sealy heads (like unto the flower's of Stcechas), are of a brown colour, and have fine pointed leaves, as I think with five small chines within, like unto the flowers of wall-pepper or stone-crop. I found only the flowers, for the seed was not yet ripe. The root is somewhat thick and strait, with many strong and thick fibers from the sides of it; it may be referred to the house-leeks, and called small indented or crenated house-leek, with scaly heads.

'This plant I found in the Danish harbour or bay on the 18th of July.

1 Aparently the Suriforige nientis. 


\section{CHAP'TER IV.}

Of Crow's-Foot. ${ }^{1}$

Some of these plants are figured in the plates, see Nos. 7, 8,9 , and 10 .

These four following plants are all crows-feet, only distinguished by their leaves. 'The first and fourth are very like one another as to their leaves, whereof they have both two sorts, the undermost broader and not so much cut, and the uppermost smaller and deeper divided; yet they differ in this, that the first does not grow so high, and puts out many leaves out of one and the same root; but the fourth hath but one long stalk, whereon sprouted out one single leaf at a place. The fourth hath yellow flowers, but whether the first hath yellow ones (which I suppose) I cannot well remember. 'The flowers of the fourth hath five leaves, broader at the ends and smaller at the bottom; they grow out of a rough perianthium or cup that is split into five also. The flowers of the first have six leares, they are small, and the seed-ressels are like one another.

The roots are differing, that of the first hath many small fibers, and the fourth hath a thicker and longer, with tender and small fibers. 'The first burns the tongue like persicaria or flea-bean, but somewhat less than in our countries: the leaves of the fourth do not burn so.

I found them both in the Danish haren, the first in great quantitics; they flower in July.

'The second hath somewhat differing leaves from the two former, for though the lowermost leaves agree with them of the first, yet they are less; and those that grow higher, and

1 Rununculus sulphureus (fig. 10). Lianunculus scelerutus (fig. 7). 


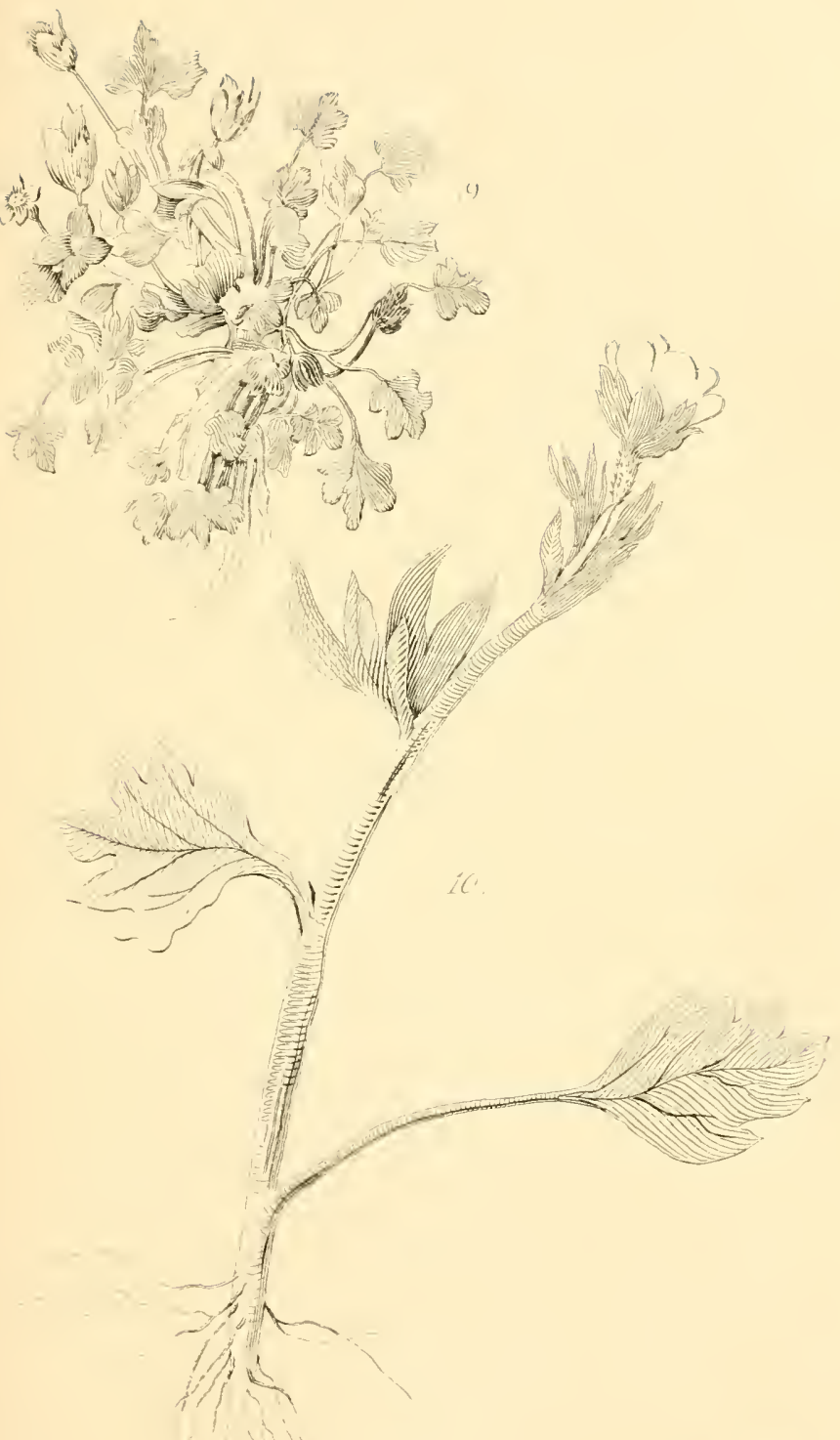




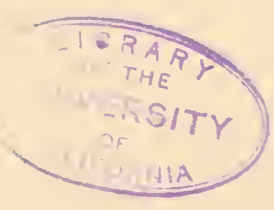


come up after the lowermost, are in two places decper cut, so that the first part of the leaf that stands out before is not rery unlike a tongue, but the two sides are but a little indented.

'There is also a difference in the leaves of this plant, as well as in the two before mentioned; for the lcaves that are nearest to the flowers are small and deeply cut, and that with two incisions, and it burns the tongue. The flower is small, and hath six, and sometimes seven leaves; the seedressel is like unto the former, only it is less. The root is like that of the first, only it hath more fibers; there is also a kind of thick sheath that surroundeth the stalk, as is also to be seen in the fourth. I found this plant near the first, in the Danish haven, the 16th of July; the third is yet smaller, but fuller of leaves, only they are less and not so deep cut, although they have also four incisions like the second; in this I did not find that difference, in the leaves between the lowermost and those that are nearer the flower. The flower is of five white leaves, its seed-ressel I could not yet see. Its roots are small fibers; I found it in the South Haren, on the 16th of July; it burns the tongue; the leaves are thick and juicy.

I found in the same place another small plant, exactly like to these, only the flowers thereof were of a purple colour, and the leaves not so juicy; wherefore I did not draw it.

\section{H A P T E R T.}

\section{Of Seurvy-grass. ${ }^{1}$}

This scurvy-grass sends forth a great many leaves from one root, that spread themselves round about upon the

'Cochlearia (one of the varialle species of the genus). See Appendix. 
ground. The stalk grows out of the middle of these leaves, which is a great deal lower than in our country, with a few leaves underneath the sprouts. The flowers are of four white leaves, they grow many on the same stalk one above the other; when one flower fades, another eometh in its room when the flower is past; the seed appears in a longish box, as you may see in the figure; when, on the contrary, in ours the seed is found in a round one. The root is white, somewhat thick and streight, with some small fibers below.

A great quantity of this plant is found on the rocks, where they are not much exposed to the east and north winds; I found it most in the South, English, and Danish havens, the earth was quite covered with it in the Danish.

It was the first herb I found in Spitzbergen, when we landed the first time; it was so small I could hardly discern it to be scurvy-grass, but afterwards we found it in its full perfection, and it seeded in the month of July. It is observable, that the leaves of this herb have but little sharpness at Spitzbergen, and therefore is much weaker than the scurvygrass of our countries, so that we eat it instead of salad at Spitzbergen, which we could not do our scurvy-grass. My figure is like that cut given in the 3rd book, 35th chap., of the German Iferbal of Matthiolus.

\section{CHAP. TI. \\ Of an llert like Stone-Crap.}

Trus plant is doubtless a kind of stone-crap, but the leaves are rough or hairy, not so thick nor so juicy as onrs are, neither doth it burn or bite like unto ours.

Before the flower fully appears, it looks like unto that of ssuld, but when it is quite blown and opened, it is of a 
purple colour, and hath sometimes five, sometimes six, and sometimes I lave scen nine leares; the stamina of the flower I did not tell, neither did I cver see the seeds thereof. 'The root thereof is very small, and one plant grows elose to the other. We found this herb on the low lands of the Engliste Haven, afterwarls we found abundance of it amongst the mosses on the 26 th of June.

\section{CHA P'LER VI}

Of a Snake-weed.

'This is a small snake-weed, and is found very rarely in Spitzbergen; the undermost leaves of this plant are the biggest, but they are not above the breadth of ones nail; they grow singly on the stalk, yet not above three of them, exeept the lowermost: the nearer the flower, the smaller they are; they have within, not far from the edge, many small knobs or spots, answering to the points of the leaves, wherein the veins or nerves are terminated; besides the leaves are not quite plain, but somewhat rumpled at the brims. Out of the root sprouts forth, sometimes single and sometimes double stalks, as you may see in the eut, and this by-stalk is always somewhat lower than the ehief stalk.

'The flower grows in a close spike, with many small fleshcoloured flowers, it was so small that I forgot to tell the leaves thercof; the seeds were not then come to maturity. The root sheweth of what kind the plant is, and wherefore it may be called bistorta or snalie-ueed, for it lieth twisted in the ground; it is about the thickness of your little finger. where thickest, hath small fibers, is brown without and fleshcoloured within, and of an astringent taste.

1 Saxifraga oppositifolia.

${ }^{2}$ Eridently a Polygonum, and the species described in the next ehapter. 
I found this herb in the Danish Harbour, on the 18th of July. My figure agrees most with that which Camerarius hath given in the fourth book and third chapter of Matthiolus.

\section{CHAP. VIII. \\ Of an Herb like unto Nouse-ear. ${ }^{1}$}

'l'Hs herb bringeth forth smooth-edged leaves by pares, they are rough and like mousc-ear. The stalks are smooth at their first putting out, but they afterwards grow rough, where the uppermost leaves grow : they are roundish at the bottom. At the end of the stalk groweth a white flower ont of its periunthium, the number of its leaves I clid not tell, nor had I time enough to observe the sced. The root is round and slender, with small and tender fibers.

It scemeth this plant should bclong unto the hairy or rough Alsine, and perhaps it may be the third or fourth kind of the hairy Alsine of Dodoneus, in the fifth book and tenth chapter of his first Latin Herbal, if the leares of his were not cut, as these are not. I gathered this plant in the South Hucen, on the 17 th of July.

\section{CHAP. IX.}

of a l'lant like unto Periwinkle.

'Tirs plant runneth upon the ground, and bringeth forth roundish leaves by pairs on creeping stalks.

'The leaves as I think are like those of perixtinlile, but they

1 Bidently a Cerestiun or Stelluriu. 
are somewhat rounder, and the largest of them are bent in before. 'The stalk is somewhat knotty and woody.

'The flower appeareth at first wript up like a lcaf, but after it is grown out a little more, one may see it to be a flower; it grows out between the leares on the same stall.

The colour and shape of these flowers I could not at that time observe, because they were not yet blown, much less could I gather the seed.

The root is long, slender, round, woody, and knotty, it hath small branched fibers at the bottom: I found it in the South Bay, behind the cookery of Harlem, on the 19th of June and the 17th of July. Since I saw neither the flower nor seeds, and in probability it would have put forth more leares, I cannot determine whether it be the pyrola minima, whereof Clusius giveth us a cutt and description in the fifth book of his rare plants, in the twentieth chapter; or whether it may be the Pseudochame Buxus of the Hortus Echstetensis, which is given by Clusius, in the rand chapter of the beforementioned book, by the name of Anonymos Colutece flore, and accurately described; and Camerarius, in his Hortus, giveth it us under the name of Anonymos Pervince folio.

\section{CHAP, X. \\ of an Herb like "Strawberry.}

'luns agrecth in its leaves with the strawberry, for it hath three cut leaves on the end of the stalks, and its flower hath commonly five leares (scldom but four) and is like a strawberry flower; the stalks are round and rough, and so are the leaves.

On the stalk you see two leares one against the other, of a differing figure and bigness, for one looketh like a hand and

${ }^{1}$ Potentillu (species). 
the other like a finger; the size also is different, for some have but three fingers, and others have more.

The flower is yellow, the leaves of the flower are roundish, how many I observed not: the root is woody, somewhat thick, with small fibers, a little scaly at the top ; it tastes dry and astringent like tormentil.

In the herbals I could find none liker it than that which Lobelius calleth Fragaria Sylvestris minime Vesca sive sterilis, and in the universal Iferdumish Herbal, in the 70th chapter of the 17th book, by the name of Fragaria non fragisera vel non Vesca; yet it differs in the flower and leaf, for the leaf in my flowers is cut decper, and the flower of his is white.

\section{CHIATER XI.}

Of the Rock Plant.

'THis plant belongeth to those called wier by the Dutchmen, and fucus in Lutin.

It has a broad flat stalk like a leaf, and yet there sprout out of it many equally broad leaves like it, as twiggs ont of a tree; at the top of the stalks there are little narrow longish leaves, some have five, others seven of these, of a yellow colour, as the herb is also, and they are transparent like glew ; I know not whether one may take them for its flowers. Close to these grow other oblong leaves, that are hollow, and as it was blown up and fill'd with wind, and many lesser blaclders round about close to one another. The leaves that are blown up have nothing in them but wind, for when I pressed them together they gave a little bounce; whether these small bladders have seeds in them or no I could not observe.

The seamen informed me, that from the sceds of that plant the small sea-snails are produced; but I am not satisficd 
whether they proceed from these bladders or from eggs, as our snails do. It may be after the same manner as we find on many leares in our country, bladders filled up with the sceds of worms or caterpillars, yet I dare not assert it, bccause I hare no opportunity to scarch narrowly into the matter; the root groweth out of the rocks, wherefore I call it a rock plant; it hath some fibers, and is sometimes round. I found this herb in great plenty, first in the South Bay, near the Coolicry of Harlem, where we take up the water; then in the Mussel Haren, at Spitzbergen; then at Cales, in Spain.

When this herb is clried, it looketh brown and blackish; it gires and groweth wet again when a south or south-west wind blows, because of the salt that penetrates it, but when the wind is cast or north it is stiff and dry.

Among all the figures that I have seen, I find none liker than that given in the 39th book and 50th chapter of the Iferdumish Herbal, by the name of Alga Marina Platyceros perosa, only that this is porous or spongy, and white. ${ }^{1}$

'Ihe leares of the great rock herb are very like unto a man's tongue; it is on each or both sides curled, but plain before and not curled; through the middle of it run two black stroaks or nerves to the stalk, and on the outside of them appear many black spots, within the black stroaks, on each side, to the middlemost plain stroak; the herb is adomed with small curles; in the middle it is quite smooth to the stalk; on the end of the leaf next the stalk are two white stronks, almost to the middle of the leaf, bending round outwards; if they were quite closed they would make an oval.

The leaf is above six foot long, and yellow, and the stalk yet longer ; the stalk is round and smooth, and of a yellow colour, like unboiled glew; nearer the root it is thicker than at the leaf, and it smells of mussels. 
The root hath a great many branches, that are divided again and stick very close unto the rock underneath the water. 'The whole plant groweth under water several fathoms: when we wayed our anchor, we pulled it up in great quantity from the ground.

'Together with this herb we pulled up the hairy plant that stands by it, about six foot long, and it is very like an horse's tail, only that here and there it hath some small knobs like nitty hair, or such as are split at the encls; the whole plant was browner of colour than the former, and its roots were fixed unto the former. ${ }^{1}$ In these plants were some redish worms, wrapt or folded up like caterpillars, with many legs.

'The herb was like dodder, wherefore it may be called water or rock silk. Amougst all the Icons that I have seen in printed herbals, I find it comes nearest to that hairy plant which Antony Donat, in his book of plants growing about Venice, called in his second book Muscus argenteus Marinus, similis Plume, only this is not as white as silver, but rather yellow or brownish. Of these two herbs we found great plenty in the South Haven, on the 20th and 21st of July.

There is another sea-plant, which I called sea-grass, whereof there is plenty in the English Huven, underneath the water, above eight foot long. The leaves were about two or three fingers broad, of a yellow colour like glew, and transparent, ending in a blunt point; at the top smooth edged, without nicks or prickles, everywhere plain and even; the leaves grew from the root round about it, as it were out of one hole. ${ }^{2}$

${ }^{1}$ Caprella (species). "Laminaria saccharina? or Alaria esculenta? 


\section{THE FOTR'TH PAR'T.}

OF THE AYIMALS OF SPITZBERGEN.

THF, PREFACE OF THE ANIMALS, BUT CHILFLY OF THE BIRDS IN GENERAT.

The animals of Spitzbergen here described, are either those with two or with four legs. About Spitzbergen also are some creatures that lice only in the water, and hate no legs (except one would talie their fins that are about their breast for legs, because, as hereafter shall be shewn, their fins are jointed litie legs underneath the stin). Some live in the water, and also upon the ice and land, and have either two or four legs.

IV'e will begin with them that have two legs, or with the birds, whereof the most live upon the water, and but few of them upon the ice or land.

\section{CHAP. I.}

Of Birds with Toes or Dirided Feet.

OF land-birds I observed but one sort, viz.:

\section{Of a Snite. ${ }^{1}$}

This snite, which is also called the strand rumner (because it keepeth about the strand), is no bigger than a lark.

1 Tringa maritima; the purple sandpiper. 
Its bill narrow, thin, and corner'd withall. Our snites' bills are at the farther end broader and roundish, and cut in with cross notches like a rasp to rasp wood withall; so that the whole upper jaw and bill looketh exactly like a rasp with its handle. Our snites are also bigger than those of Spitzbergen, otherwise they are very like one another in shape and colour ; this bill, both above and below, is four square, of a brownish colour, and about two inches long. The head is roundish, and of the same thickness with the neck.

Their feet are made of three divided claws before, and one behind, which is very short; their legs are not very long. It is of the colour of a lark; but when the sun shines upon it, it shews blewish, very like those two colours observed on our ducks' necks when the sun shines upon them: they feed upon the little gray worms and shrimps. We shot some of them in the South Harbour, near the cookery of Hurlem: they had not the taste of fish at all.

\section{Of the Snow-Bird. ${ }^{1}$}

The snow-bird is no bigger than a sparrow, and like a linnet in his shape, bill, and colour. The bill is short and pointed, its head of the same thickness with its neck. The legs are also like linnets'; their feet are divided into three fore-claws, with longish crooked nails; the hinder claw is somewhat shorter, but hath a long bended spur or nail. 'The legs are grayish, and not very long.

From their head over all their belly to the tail they are white, like snow, but all over their backs and wings they are gray. Some of them are gray all over, but these are little ones.

I can tell nothing of its singing, only that it whisseleth a little, as birds use to do when they are hungry.

\section{Plectrophanes nivalis; the snow bunting. (See Appendix.)}


When we sailed near the ice, they came in great flocks to us in our ship, near the Island of John Mayen, and were so tame that you could take them up with your hands. They run upon the ice, where I only saw them, and not upon the land, which is the reason that they are called snow-birds.

'They kept with our ship till we catch'd the first whale, and after this the other birds frightened them away.

We fed them with oatmeal, but when their bellies were full, they would not suffer themselves to be taken up. We put some of them in a cage, and hung them up in the cabin, but they did not live long.

We eat some of them, and they were not of an unpleasant taste, but very lean. If I may give my opinion why the birds flic to the ships, I believe that they are stray'd from the island, so that hunger compels them to the ships for food.

3. Of the Ice-Birds.

I saw also in the English Haven a very beautiful ice-bird, which was so tame that we might have taken him up almost with our hands; but we would not go too near him with our gun, for fear that we should shoot him all in pieces, and so spoil his curious feathers; so we missed him, and he flew away.

The sum shined at that time upon him, which made him look like gold, so as it dazled our eyes almost. He was as big as a small pigeon. I would willingly have delineated him, if we could have catcherl him. I saw but this one of the kind. 


\section{CHAP. II.}

Of the Broad or Web-Footed Birds.

T'InEre are several sorts of these about Spitzbergen. Some of them have thin pointed bills, others have thick and broad ones. Some of these thick-billed ones have them divided or parted, as the mallemucken (mad gnats in English); others have undivided one, as the parret so called.

There is also considerable difference in the heels of these birds, for some of them have heels, as the mountain-ducli, livmex, and mallemuclis; others have them not at all, as the burgermeister, rathsher, strundjager, kutyegehf, parret, lumb, pigeon, and the red-goose; no water sticks to their feathers, no more than on the swans and other water-fowl, for it runs off from them as if they were oiled all over. Some are birds of prey, others not. There is also a difference in their flying. Some flie like unto a partridge, as that called the pigeon; others, like swallows, as the lumbs and red-geese; othcrs, like the mews, as the mallemucke, rathsher, and strundjager; others, like the stork, as the burgermeister.

'The birds of prey are, the burgermeister, rathsher, strundjager, kutyegehf, and mallemucke. There is also a great difference in their flesh; the birds of prey are not so good to cat as the others, except you hang them up by the legs for some days, that the train-oil may rm out of them, and the air blow through them; and then yon do not taste the trainoil so strong, for else it would make you vomit. 'The pigeons, parrets, red-geese, and ducks are the most fleshy; the old lumbs have a very rough and dry flesh, not to disparage the rotges, kermews, and young lumbs when boiled, and the fat taken away from them, and aftcrwards fryed in butter; for then one may make a shift to eat them ; but if you should cat their fat, it would romit and disorder the stomach very 
much. These birds, exeept the strundjager, lirmow, and mountrin-duck, all make their nests upon the ligh rocks, where they are secured from the foxes and bears; but some of them make their nests higher than others.

They sit in so great numbers or flocks upon the rocks, chiefly at the time when they hatch their young ones, which is about the latter end of June or beginning of July, that if they flic up when the sun shineth, they shade the ground like a clond, and make so great a noise that one man can hardly hear the other.

The kirmees and mountain-duclis, and also the strundjagers, make their nests on low grounds (that one would think the high water must needs run over them), on the small islands, where they are secure from the foxes; but not from the white bears, for they swim in the water from one island to the other. We took up great store of their eggs.

The nests of these birds are not all made after the same manner. For the mountain-duck makes its nest of the feathers of its own belly, mixing them with moss.

'The feathers of these nests are not the edder down brought us from Island, for that cometh from great birds (that the inhabitants there call edder), and costeth, when it is cleansed from the moss, a crown a pound, as I have been informed; but the feathers of the mountain-ducks of Spitzlergen, which they call down, the seamen put into their pillows and straw sacks, which if they should be cleansed would be more worth.

The lirmex layeth their eggs upon moss, and so do the rotges. The nests of the rest of the birds were too high for us, so that we could hardly, and not without great difficulty, reach them. If it be never so dark by reason of a mist, yet every bird knoweth how to find their own nest again, and flyeth directly to it.

1 The eider duck is the Somateria mollissima of naturalists, found in Spitzbergen, Iceland, and the northern larts of the British Islands. (Sce Appendix.) 
Concerning the names of the birds, I have made use of those that the seamen have given them formerly, according to their own fancy, that he that heareth them called by these names, may also know how to find them by them in this book. Some of these birds, as lumbs, strundjagers, mallemucks, kirmeres, and the meros called kutyegehfen, I have also seen about England, Scotland, and Ireland; and also in the Spanish Seas, nay cven upon the Elve by Hamburg. I have heard the kirmew and kutyegehf cry ; but there is a difference, as well beween the beasts as men of other countries.

\section{Of the Rathsher. ${ }^{1}$}

First of the rathsher (or alderman, in English), for this is the first of the thin-billed birds that have three claws, and is called so by the seamen because he is a very stately and handsome bird, but less than that which they call burgermeister (or mayor, in English).

This bird hath a sharp, narrow, and thin bill, and hath only three claws or toes, that are joined together by a black skin, but he hath no claw behind. His legs are not very long, and black, as the eyes are also.

'The bird is whiter than the snow, for when you see him upon the ice, you may distinguish him from the snow; he shews very beautiful with his white body, his black bill and eyes, black legs and feet; and besides he is very well shaped. His tail is pretty long and broad, like a lady's fan.

His cry is somewhat lower than the little lirmeves, as if he did say liar, when she cries lir : he spreads his wings and tail out when he flies, as the strundjager or crow doth. He doth not willingly swim in the water as the other birds do, nor doth he much care for wetting his fect, but he stays rather where it is dry, yet he lores fish mightily; and so the proverb that we commonly say of the eat is true of him,-

1 The ivory gull (P'rgophilu eburneu). (Sec Appendix.) 
The cat lores to eat fish, but does not love to wet her feet. I have seen him upon the ice feed on the dung of a sea-horse, upon whose body he will rest when he is alive, as crows will do in our countries. He flieth commonly alone by himself, but where there is a prey they flock in great numbers.

I did delineate them in the Shallow Corner (called Shallow Point), in Spitzbergen, on the 10th of July; when we shot him he was not wild at all, so that I could have knock'd him down with the gun.

\section{Of the Pigeon. ${ }^{1}$}

The pigeon, or rather the pigeon-diver, is also one of the beautifullest bircls of Spitzbergen; it is of the bigness of a duck; the bill is somewhat long, thin, and sharp-pointed; at the point the upper bill is somewhat crooked, about two inches long, and hollow within. It hath but three red toes on its feet, with crooked claws; it hath short redish legs, and a short tail. Some of these birds are black all their body over, but others, and so was that which I delineated, about their wings; and in the middle they are white pyed with black, but underneath the wings they are quite white; others are in the middle of their wings quite white: their bill is red within; the tongue also red and hollow; they cry like young pigeons, whence they have their name, for they are in nothing else like them. In their crops I found shrimps or prawns, and small sandstones.

They do not flie high over the sea, and their flight is very like the partridges: they do not flie many together as the lumbs, but usually by pares, and sometimes one alone by its sclf.

'They can keep a great while under' watcr, wherefore they may be called diving pigeons.

"The black guillemot (Uria Grylle); called "Tystie" in Shetland. (Sec Appendix.) 
But chiefly when they are pursued by men, or if their wings be hurt by a shot, they will dive and keep a great while under water; and somctimes they get underneath the ice, and there they are suffocated; they were as nimble and quick under water (if their wings or feet are not quite shot off) as we could row with our boat. Their flesh is good to eat when the fat is taken away from it, if afterwards it be fryed in butter. The first diving pigeon I got on the 23rd of May on the ice, and afterwards at Spitzbergen, where they are seen more frequently.

\section{Of the Tumb. ${ }^{1}$}

This bird is likest in his bill unto the diving pigeon, only it is somewhat stronger and crookeder.

He hath black feet with three black toes, and as many black nails; his legs are black also and short.

He is quite black at the top, but underneath his belly, even to the neck, he is snow white; his tail is short. His cry is very unpleasant, most like that of a raven, and they cry more than all the other birds, except the rotger-divers; he is bigger than the diving pigeon, as big as a middling duck. In their crops I find small fish and prawns, and also some sandstones: and one ${ }^{\circ}$ them flying over our ship, dropp'd a large red prawn into the ship. I also delineated it in the mentioned place. They say likewise that small fresh river fish are their prey; but this I cannot relate for certain.

When they have young ones, they commonly sit by the old ones, one or two on the water, who teach them to dive and swim. After the old ones have brought their young in their bill from the rocks to the water, the preying bird called burgermeister sometimes catches the young ones when the

1 The common guillemot (U'ria Troite), and also the Uria Brunnichii may be included under this head. 
old ones are not present, and sometimes when they are also, for they are not able to resist them.

'They love their young ones so well, that they will be killed before they will leave them (and will defend them as a hen doth her chickens, swimming about them); at other times they are very hard to be shot; for as soon as they sec the fire, they are immediately under water or fly away. They fly in great flocks, with pointed wings like swallows, and move their wings much in their flight. One can hardly know the young lumbs from the old ones at the first sight, if you do not take exact notice of their bills; for the upper part turns beside the under part at the point, and the undermost beside the uppermost, as you see in the Cross-bill; yet not so much in these; and it is commonly done in the fifteenth, sixteenth, to the twentieth year of their age. The old ones are full of flesh, but it is very dry and tough, and therefore unpleasant to eat.

They boil them like the pigeons, and seum off the fat when they boil, then they fry them in batter. I did not see them upon the ice, but abundance of them upon the mountains: they go waddling from one side to the other, like the diving pigcons. I have seen many thousands of them together in the Danish harbour, on the mountains, on that side where the east and northern winds could not blow hard or not fully upon them (and so do all other birds chuse such places on the mountains for their habitations), where the herbs do grow.

But I saw not so many by the haven of Magdalen, where I drew my figure on the 25th of July. Afterwards I saw some of them in the Spanish and North Sea, not far from the Heilgland.

\section{Of the Mew called Kutge-gehef. ${ }^{1}$}

This is a beautiful mew, and is called kutge-gchef because it cryeth so. He hath a bill somewhat bent, as the Burger-

1 The Kittiwake gull (Risse tridectyle). 
meister; on the undermost part of its bill is a small knob or rising: about his black eyes he hath a red circle, as the Burgermeister, and he hath but three elaws, joyned together with a black skin.

The legs are also black, and but short; the tail is somewhat long and broad, like a fan.

All the belly is as white as snow; the wings and back are grey, and the point of the wings black. He is almost as big as an ordinary mew, but something less than the Strunt-jager. When we cut the fat off from the whales, we saw abundance of them fly by the ship, and heard them ery.

When the seamen have a mind to eatch some of them, they bait their hooks with a piece of whales fat, and so tye the hooks to a line, and fling it into the sea, and so they eatch not only these but all the other birds of prey. He flieth with small wings as a common mew, and dives not. His food is the fat of the whale. He is hunted by the Strunt-jager (in English dung-hunter), who leave him not till he dungs, which the Strunt-jager eats. ${ }^{1}$

This I could hardly believe at first, until afterwards I saw it my self very often. That which I drew was catched by our ship-boys with a hook, in the South Haven. I did peculiarly observe in this bird that it used to swim upon the water, and hold its head up against the wind if it was never so great a storm; and so we found whole flocks of them swim upon the water together.

This is not only to be understood of this bird, but also of all the rest, for they look against the wind that their feathers may not be blown asunder and opened; for if they should sit or swim with the wind, their feathers would be blown asunder by the cold wind, and so the cold would get in between them to their skin; which perhaps might prejudice their health, for birds are covered with their feathers as men are with their clothes.

1 The Aretic Skua (Stercorarius parasiticus). 
And so, when they fly up, they press against the wind with their bodies and expand their wings, and so fly away very swiftly; also their feather's would be entangled, so that they could not have a sure and steddy flight, but faulter in their fying like birds that learn to $\mathrm{fly}$. There is but little meat upon them; we eat but the legs and the breast, for the wings are nothing but skin and bone. We have a proverb and say: Thou art as light as a mew. This we may very well say of these mews. I hare seen them since in the Spanish Sea, and also in the North Sca, but yet they differ from these; and so do the beasts of all countries.

\section{Of the Burgermeister. ${ }^{1}$}

The Burgermeister (in English Major), is the biggest of all the birds of Spitzbergen, wherefore this name is given him as being the chief of them. His bill is crooked, of a yellow colour, narrow and thick; his under-bill is somewhat rising or knobby at the point or end, a great deal more than the kutge-gehefs, which looketh very pretty, as if he had a chery in his mouth; he hath longish nostrils, and a red ring about his eyes, as I mentioned when I spoke of the kutge-gehef; he hath but three claws of a grey colour ; his legs are grey, and not quite so long as those of a stork, yet he is almost equally big with him.

His tail is broad, like a fan, and white, which is chiefly to be understood of these birds when they fly; his wings are of a pale colour, and so is also the back, but the wings are white at the tip, and so is the whole body. He builds his nest very high in the clifts of the rocks, where you can neither shoot nor catch them any other way ; which was the reason I could not see their nests. I have seen sometimes two, three, and four of their young ones together; we shoot most of them when we draw a dead whale behind our ship, where they flock in great numbers, and bite off great pieces of the fat of

1 The Glaucous Gull or Burgomaster (Larus glaucus). 
the whale; at other times we must shoot at them a great distance, as at other wild birds, such as ravens, herns, and the like.

His cry is like the cry of some ravens that I have sometimes heard; he flyeth in the air like a stork; he preys upon young lumbs as the hawk doth upon all sorts of birds; he feeds also upon the fat of the whale, whereof he doth swallow down pieces as big as ones hand whole.

The Mallemucks are mightily afraid of him; they will lye down before him (when they are upon the carcass of a dead whale); then he bites them about the neck, which I believe doth not hurt them much, because they have a very thick skin, for else they would oppose and resist him, or fly away: but they do not matter it, neither will they leave their meal for his biting. I have seen him also about the sea-horses, whose dung he eats. He flyeth commonly single, except when they meet at their prey. He loves to rest on the water, but doth not care much for diving; we shot one before the Weilegat on the 10th day of July.

\section{Of the Rotges. ${ }^{1}$}

This bird is a diver, and might be rather called the diving rotge. His bill is crooked but short, somewhat thick, of a black colour; his feet have but three claws, with as many black nails, and are joyned by a black skin; his legs are short and black; he is almost all over black, except his belly, which is white.

Some of this kind have their wings spotted with white and black, like the diving pigeon; no water sticketh to their feathers, no more than to a swans; they are most of them like hair on a very thick skin : their tail is short.

'They are very much like a swallow in their shape; I took them at first to be swallows, for they fly like them; they are

1 The little Auk or common Rotche (Aretica ulle). 
in great flocks together, as the swallows are when they are about to hide themselves against the winter.

They go wabbling from side to side as the divers do ; they cry rery loud: Rottet, tet, tet, tet, tet, at first high, and so by degrees lower and lower; and this their calling or crying is the occasion of their name. 'They make more noise than any other bird, because their voice is shriller; but the lumbs in this are not much inferiour to them, although they cry lower; the burgermeister, rathsher, and the whole crew of birds of Spitzbergen, strike in with them, so that one can hardly hear another's words.

'The calling or crying of the rotges amongst one another sounds almost, at a distance, as if you hear a great many women scolding together: they are somewhat bigger than a starling.

They build their nests in the clifts of the rocks, yet not all of them, for some make their nests upon the hills or mountains, of moss, where we found them, and we killed abundance of their young ones with sticks. They feed upon the grey worms that are like crawfish, which are dclineated hereafter: they also eat the red shrimps or prawns. ${ }^{1} \mathrm{We}$ got the first of them on the ice on the 29 th day of May, and afterwards more of them by Spitzbergen.

They are very good food, and the best next the strandrunner; are fleshy and fattish; we boyl and then roast them.

\section{Of the Strunt-jager, or Dung-hunter. ${ }^{2}$}

This bird hath a bill somewhat blunt before, and crooked, and is thick; if I remember, it is black.

He hath but thrce claws, which are joyned together with a black skin; his legs are not very long; his tayl, which is like unto a fan, hath this mark, that one feather thereof stands ont before all the rest: he is black on the top of his 
head: his eyes are black; about his neck he hath a dark yellowish ring or circle; his wings, as well as his back, are brown; underneath his belly he is white; he is somewhat bigger than the mew called kutge-gekef; he hunts and flies in the air after the mew liutge-gehef, so long torments her until she avoideth her dung, on which this bird feeds, which he catches dexterously before it falls down into the water ; and this is the reason why they call him Strunt-jager, in English the dung-hunter.

He flyeth with the mews called Kutge-gehef, which do not fear him in the least, and they are both equally swift in their flying, but when he intends to make them dung, he hunts them and makes them cry out very loud, but he himself seldom cries. He generally keepeth but to one mew, but if two or three of the mews be together, and one makes her escape from him, then he hunts the other two, and flyeth sometimes above and sometimes underneath them. I could never see him hunt after any other birds, but once I saw him fly after a mallemuck; but I saw him soon leave her, perhaps because her dung did not please him. I am of opinion that this dung, because it is thin, serves him instead of drink, for else he eats the fat of the whale for his food: he builds his nest not very high.

He gocs upright upon his legs, like the Burger-meister, Ratsher, or Tutge-gehef. It is a rare bird, and I saw but very few of them. He flies commonly alone; I saw very seldom two or three of them together; he flics like the ratsher, or like a crow, but his wings are somewhat more pointed at the ends.

He hath a loud voice, when he cries it sounds as if he did say, IJa. 'To some it scemeth, if it be at a distance, as if he cried, Jo han. His flesh is not better than that of the other birds of prey. I got him on the 11th of July near to the Dearharen, or Dear-bay, in Spitzbergen; afterwards I saw this bird, behind Scotlend, liunt after the mew liutge-gehef. 


\section{Of the Diving Parret.}

This is commonly called the Parret. Amongst all the webfooted birds that have three claws, this hath a pcculiar bill; and because it scem'd to those that gave him this name to be like that of a parret, therefore they called him also a parret; but in truth his bill is not at all like that of a parret; its bill is broad, and full of slender strokes of several colours, viz., red, white, and the broad part thereof is black; the uppermost as well as the undermost are both pointed; the uppermost arch is red, and his upper bill hath a thin bended hook; the undermost hath a yellowish arch, and is towards the end downwards cut off somewhat sloaping. The upper part of its bill, as well as the lower part, is about three fingers broad, and about the same length, if you measure the upper and undermost together: he hath on the upper bill four arched or bended oblong pitted holes, and on the lower he hath as many, although the furthermost is not altogether so plain.

These holes or pits of the upper and lower bill make together a half-moon; and the parts that are elevated make in the same mamer, as well as the pitted or hollow ones, a halfmoon.

By these holes are as many raised or elevated parts; the uppermost of them is as broad as the three furthermost ones together, and hath underneath on each side a longish hole, which without doubt are his nostrils; but the uppermost on the under bill is about a straws breadth broader; the upper broad part is blackish, and sometimes blew.

On this broad part of the upper bill that is thus elcvated above the rest, is towards the cye a long whitish piece of cartilige that is full of holes, whereon you see towards the inner part of the mouth something like a nerve, which also reacheth towards the under part, and there endeth itsclf, whereby the bill is opened and shut.

1 The Puffin or Coulterneb (Fratercula Aretica). 
His feet have also but three claws, joined with a red skin between them, with three short and strong nails; the legs are but short, and of a red coloux; he walks wabbling.

About his cyes he hath a red ring, and above this ring stands upright a little horn, and underneath the eyes lyeth another little, longish, black horn cross over.

His tail is short: the head is black at the top unto the horn; but his cheeks are white; about his neck he hath a black ring; all his back and wings also, at the top or the outside, are black, but underneath the belly is white. They fly either singly or by pairs, and have sharp-pointed wings like the lumbs. He will keep a great while under water. He cats like the rest, red shrimps or prawns, small fish and worms, and also the sca-spiders and star-fish, for I found something in his stomach that looked like pieces thereof, but they were almost digested.

He hath more flesh upon him than the diving pigeon, and is very good to eat. I never saw him among the ice. 'This whereof I show you the draught was shot at Schmerenberg in Spitzbergen, on the 20th day of June, but afterwards we got several more.

\section{Of the Mountain Duck. ${ }^{1}$}

Hitherto we have described the wcb-footed birds that have three claws that are not divided, that I saw and got about Spitzbergen; I must now describe those that have undivided feet with four claws, whereof I found thrce sorts, viz., the mountain duck, kirmew, and mallemucke.

The mountain duck is a kind of our wild duck, or rather wild goose; for she is of the bigness of a middling goose, and is more like a goose about the bill. It is a very handsome bird, because of its delicate spotted feathers. They dive under water as other ducks do. 'The drake hath black and white spotted feathers, and the duck hath feathers of the

\footnotetext{
1 The Eider-Duck (Somateria mollissima).
} 
colour of a partridge. The hindmost claw is broad and short, with a short nail; the tail is bobb'd, like that of other ducks. I could find nothing in their maws or gizzards that could make me certain of their food, but only sand-stones. They fly a great many of them in flocks like other wild ducks; when they do see any men, they hold up their heads and make a very long neck. They make their nests upon the low islands; they make them of the feathers of their bellies, which they mix with moss; but these are not the same feathers which are called the edder-down.

We found their nests with two, three, or four eggs in them, the most whereof were rotten when we came to Spitzbergen, but some of them were good to eat; they are of a pale green, somewhat bigger than our duck-eggs; the seamen made an hole at each end, and so blew the white and the yolk out, and strung the shells upon a packthread. I would have brought some of them to Hamburgh, but they began to stink, so that I was forced to fling them away, although the shells were entire. These ducks have a very good flesh; we boyl'd and roasted them as we did the other birds, but the fat of them we flung away, for it tasted of train-oyl, and made us romit.

The ships that arrived at Spitzbergen before us got a great many of them.

These mountain duclis are not at all shy or afraid of men when we first arrive there, but afterwards they grow quite wild, so that you can hardly come near enough to shoot them. 'That which I have drawn here was shot in the South Bay (in Spitzbergen), on the 18th of June.

10. Of the Kirmew. ${ }^{3}$

The firmew hath a thin sharp-pointed bill, as red as blood; she shews very large, especially when she stands upright,

1 The Arctic Tern (Sterna macroura, or Arctica). 
because of her long wings and feathers of her tail, but when the feathers are off there is no more meat than upon a sparrow. It is peculiar to this bird to have very sharp-pointed wings, and its tail is longer than that of a swallow, and as long as the longest feather of the wings. Because of these long and sharp-pointed feathers in her wing and tail, she might very properly be called the sucllow-mew, but it is commonly called kirmew from its cry. The claws, as well as the skin between them, are as red as blood; the nails are black on all the four claws; the hindmost claw is very little; the legs are short and red; it shews very brisk and pert when it stands upright on its legs. The head at the top is black, like a black cap; the sides of the head are snow white, and the whole body is of a silver colour, or white enclining to grey; the wings and tail are white underneath; one side of the feathers of the wings are black. All these differing colours, together with the blood-red bill, red legs and feet, make her very beautiful : her feathers are thready or hairy; she flies singly, for so I saw her always in the South Haven, and in other places where we were. Where their nests are they fly in great numbers; these they make of moss. One can hardly discern their eggs from their nests, for both of them are of a dirty white, but the eggs have black specks; they are of the bigness of a pigeon's egg ; I eat of them at Spitzbergen, and found them very good, they tasted like the lapwings eggs; the yolk was red, and the white blewish; they are very sharp-pointed at one end. She defends her nest and eggs, and fies directly at a man, biting and crying. It is the same with her as what we say of the lapwing; she cndeavours to defend all the meadow, and yet cannot defend her own nest.

I brought about thirty of their eggs with me to Hamburgh, but they were rotten and stunk. It is a kind of a hawk, and throws herself into the water as other mews do.

I am of an opinion that she feeds on the small grey worms, 
and perhaps on shrimps and prawns, for I found no other food they could get.

I shot but one single bird of them flying, which I did not eat of, because the large shot had torn it very much.

'This bird is quite grey in our countries, which differs much from that of Spitzbergen, whose feathers are much finer. That here delineated was shot by the Birds Song in Spitzbergen, on the $20 \mathrm{th}_{\mathrm{l}}$ of June.

\section{Of the Mallemucke. ${ }^{1}$}

This bird hath a remarkable bill, which is severally divided : the uppermost bill hath next to the head oblong and small nostrils; underneath them groweth out as it was a new bill, that rises up, is crooked, and very sharp-pointed.

The under part of the bill consists partly of four pieces, two whereof meet in a point together downwards, the other two gape upwards; the two undermost that meet in a point, meet exactly with the point of the upper bill. The hinder claw of the feet of this bird is very small, of a grey colour, and so are the other claws and the skin between them. The tail is somewhat broad, the wings are longish, after the manner of the Firmero. They are not always of the same colour; some are quite grey, which we take to be the oldest, others are grey on their back and wings, but their head and belly are white, which are the young ones. 'This is generally thought, but I am of opinion that this difference of colour proceeds rather from a difference in kind than from a difference in age; for the grey ones I only saw about Spitzbergen, but the grey and white ones, although I have seen some few of them at Spitzbergen, yet we saw abundance more about the North Cape, and also about Hitland and England. He flies like a great mew, hovers near the water with a very small motion of his wings.

1 The Fulmar Petrel (P'rocelleria glaciulis). 
They do not avoid a storm as our mews do, but they take good and bad together, as it happens; ours bend themselves like an ear of corn with the wind, which the mallemucks do not. They do not much care for diving, but when they wash themselves they sit upon the water, and put their wings a-cross one over the other. They fly singly; when they go to fly up they wabble a great way before they can raise themselves upon the wind, but the Lumbs and Parrets that have but small wings do it more. When they ran upon the deck of the ship, they could not fly up before they came to a place where a step went down, or from some advantageous rise. 'They flock in great numbers when we catch whales, and light down upon the live whales, bite them in their backs, and pick out great pieces of his fat, even when he is yet alive; and when we cut up the dead whales, there came so many of them about us, that we could not imagine from whence they could all come, so that we were forced to kill them with sticks and with broad nets in frames, such as they use in the Tenis Court, to be rid of them. They are so bold, that they would not fly away although they saw us come upon them; but suffered themselves to be killed in great numbers, which we hung upon the tackle of our ship.

But after they began to be more shy of us, and would not stay so long. They flock in so great numbers after the whales, that many of them are discovered by them; wherefore I fancy that he flings up some fat when he blows the water out, which the mallemucks eat. But a great many more, when the whale is wounded, follow the bloody track left in the watcr, for then they are numberless. They also often discover a clead whale, and so we get them sometimes without any great trouble.

His name is given him because he is so silly or mad (which the Dutch call mall) to suffer himself to be so easily killed, whereunto is put the word mucke, which signifies a gnatt, because they are as numerous as gnatts; so that the 
name mallomuclie signifieth as much as silly gnatts, or mad guatts.

They eat so much of the fat of the whales till they spew it up again, and tumble themselves over and over in the water until they vomit up the train oyl, and then they begin to eat afresh, until they grow weary of cating. They bite one another, and fight together, which is very good sport, about a picce of fat, fiercely, although there is enough for them all and to spare.

When they are full they rest upon the ice or water. I really believe it is the most devouring bird of all, for he eats till he can stand no longer, but falls down. He bites very hard, but the Burgermeister bites yet harder, to whom he submits himself, and lies down before him to be bit by the Burgermeister, which he does very severely, yet the mallemucke fecls little or nothing of it, his feathers are so thick; which I conclude because he is not easily shot, but will endure a great blow; nor is it easie to kill him with a stick at one blow. When they stecr themselves in the water with their legs, they have continually an eye upon their prey, yet they mind both the man and their prey; but if you have a long stick, they cannot get up so soon or swift but you may have a blow at them. He is the first and commonest bird of all you see in Grecnland; they cry all together, and it sounds afar off as if they were frogs. He walks but ill upon the land and ice, like a child that just learns to go, but he understands better to fly; you see him always near unto the surface of the water, for he is very light. Of all the birds of prey, I believe, he hath the least meat on him. He builds his nest high on the mountains, yet not so very high as the Burgermeister; yet it was too high for me, I could not come at them. His breast and legs only are to be eaten; they are tough and taste strong of train oyl; when you will eat them you must hang them up by the legs (that the fat of the whales, or the train oyl, may run out of them) for two or 
three days, and that the wind may blow through them, and the frost pierce them also; then you lay them into fresh water, that the rankness may be drawn out, afterwards boil and fry them in butter. They are every where seen in the North Sea, as I have said before, yet they are differing.

\section{CHAP. III.}

Of some other Birds that I did not Catch or Delineate.

Amongst these are the red gees, which were shewn unto me as they were flying. They are geese with long legs, that fly in flocks; there is many of them in Russia, Norway, and Jutland.

Then I saw another bird flying singly with broad feet, a very handsom bird, called John of Ghent; it is as big as a stork and of the same shape, with white and black feathers; he hovers in the air, and moveth his wings but very little; when he cometh to the ice he turns back again. It is a kind of a hawk, and I have reason to believe that he hath a very sharp sight, for he shoots down from a great height into the water. They say that the brains of this bird are in great esteem, but for what I could never learn.

He is also seen in the Spanish Sea, and every where in the North Sea, but most commonly he is seen where they catch herrings.

I was also informed that a black crow was seen in Spitzbergen; other birds are not seen there, except it may be now and then a single one that strays and so cometh thither, as the crow did. All these birds come at certain times, and abide at this place as long as the sun shines; afterwards, when the cold begins to encrease, and the nights lengthen, cvery one of them returns to its own place again. When 
they are going from thence they gather all together, and when they are all met they fly away, every kind by themselves, which hath been rery often observed: whence I conclude they cannot live in this intolerable cold place in the winter. They rest as well upon the water as the land (and when they fly up they look against the wind), for else they would be quite tired in this long journey.

Whether the mew called rathsher, that does not love the water, performs its journey in one day, I camnot tell ; or whether necessity compels him to rest upon the water.

Which way those birds that have divided claws on their feet, as the snite, the snow-bird, and the ice-bird, get over the water, I know not.

\section{CHAP. IV. \\ Of the Four-Footed Creatures.}

1. Of the IIart or Deer. ${ }^{1}$

This is not very unlike unto the lart; it hath cloven feet like it, and its horns are also like unto a hart or elke; they have three or four branches on each side, which are about two inches broad and about a foot long; their ears are long, and tail very short : he is of a greyish yellow colour, like an hart or deer. When they see a man they run away; if you stand still they stand also, then you must immediately fire at them if you have a mind to hit them. They cat the herbs and grass. They are every where abont Spitzbergen, but above all in the Rene-field (or Deers-field), that hath its name from thence, where they'r very plentiful, and also upon the Foreland near the Muscle Haven. I never saw

1 The Rein-Deer (Trerandus Rangifer). 
them swim in the water. As I was informed, some men did kill fifteen or twenty of them on the Vogel-song (Birds-song), the meat thereof roasted is of a very pleasant taste. We killed some of them presently, at our first arrival in the spring, that were very lean; wherefore we may conclude, that they remain in this barren and cold country of Spitzbergen all winter long, and are contented with what they can get.

\section{Of the Fox. ${ }^{1}$}

Between our foxes and those of Spitzbergen there is no great difference; one of them I saw run by our ship, very near it, his head was black and body white. They make such a noise, as afar off it sounds as if a man laugh'd. We saw them also rum on the ice. Their food falls but short there, they live upon birds and eggs.

They go not at all into the water; we were hunting one of them in the South Haven, and had surrounded him with twenty men, the water was on one side of him, and we endeavoured to drive him into it, but he would not, but jumped through one man's legs and ran up into the momntains, where we could not follow him.

The ships erew inform'd me, that when he is hungry he lies down as if he was dead, until the birds fly to him to eat him, which by that trick he catches and eats. But I belicve that this is a fable.

\section{Of the White Bear. ${ }^{1}$}

These bears are quite otherwise shaped than those that are scen in our country; they liave a long head like unto a dog, and a long neck, and they bark like dogs that are hoarse, and all their whole body is much otherways shaped than

1 The Aretic Fox (Vulpes Lagopus).

2 The Polar Bear (Thalassarctos maritimus). 
ours. They are slendercr in the body, and a great deal swifter.

'Their skins are brought to us, which are very comfortable to those that travel in the winter; they prepare or dress the skins at Spitzbergen after this mamer: they heat sawdust, and tread thesc skins in it, which sucks up the fat, and the skins become to be dry, after the same manner as we use to take out spots of fat out of fine linnen or other clothes, when we hold it against the sun: they are of the same bigness as ours, great and small : their hair is long, and as soft as wool: their nose and mouth are black before, and their talons also black. The fat of their feet melted out, is used for pain of the limbs; it is also giren to women in travail, to bring away the child; it causes also a plentiful sweat. 'The said fat is very spongy, and feels very soft; it is best to try it up there presently; I strore to keep it until I should come home, but it grew foul, rancid, and stinking. I beliere it would be very good to try it up with orris-root, for then it would remain the longer good and smell well.

The other is like snet when it is tryed up, it becometh thin like train-oyl, or the fat of whales; but this is not to be compared to the other for vertue and goodness, it is only used in lamps, where it does not stink so much as the train-oyl: the skippers melt it out there, and bring it home with them to sell it for train-oyl. Their flesh is whitish and fat, like that of a sheep, but I did not care to try how it tasted, for I was afraid that my hair would turn grey before its time, for the seamen are of opinion, that if they eat of it, it makes their hair grey. They suckle their young with their milk, which is very white and fat, as I observed, when we cut up an old suckling she one. They say our bears have a very soft head, but I found the contrary in these at Spitzbergen, for we struck them with large and thick cudgels upon their heads, with such blows that would have knock'd down a bullock, and yet they did not matter it at all. When we had a mind 
to kill them, we were forced to run them through with our launces.

They swim from one sheet of ice to the other, they also dive under water; when they were at one side of our longboat they did dive, and came up again on the other. They also run upon the land. I did not hear them roar so as ours do, but they only bark.

We could not discern the young ones from the old ones, but only by the two furthermost long teeth, which in the young were hollow within, but those of the old ones were close and solid. If you burn their teeth and powder them, and give them inwardly, it disperseth coagulated blood. 'The young ones keep constantly close to the old ones; we observed that two young ones and an old one would not leave one another, for if one ran away, it turned back again immediately as soon as it did hear the others, as if it would come to help them. The old one run to the young one, and the young one to the old one, and rather than they would leave one another, they would suffer themselves to be all killed.

They feed upon the carcasses of whales, and near them we killed the most: they also eat men alive when they have an opportunity to master them. 'They remove or roll away the stones of the burial places, open the coffins, and eat the dead men, which many have seen; and we can also conclude it from hence, because we find the dead mens bones lye by the coffins that are opened. 'They also eat birds and eggs. We kill them with guns, or any other way we can. We caught three of them, one whereof I drew after the life, on the 13th of July.

What becometh of these bears and foxes in the wintertime I do not know; in the summer they have in some places, for a few months, provision enough, but in the winter, when the rocks and hills are covered with snow, there is but very little to be had for them; yet being it is supposed that the deer stay also there all winter long, I believe that these beasts do the same. 
4. Of the Sea-Dogs, called Rubbs and Seales. ${ }^{1}$

I have still two more beasts to describe, that live as well in the water as on the land and ice, and they have also on their feet five claws like fingers, that are joyned together with a thick skin, like unto the feet of a goose. The most known of these is the seale, which they also call salldogg and rubbe in the German language; the head thereof is like unto a dog's head, with cropt ears. 'Iheir heads are not all alike, for some are rounder, and others longer or leaner: he hath a beard about his mouth, and hair on the nose and the eyelids, yet selclom above four ; the eyes are very large, hollow, and very clear: their skin is grown over with short hair. They are of several colours, spotted like tygers, some are black with white spots, some yellow, some grey, and others red: their teeth are sharp like a dogs, wherewith he can bite off a stick as thick as ones arm. On their tocs they have black, long, and sharp nails or claws; their tail is short; they bark like looarse dogs; their little or young ones mew like cats; they go lame behind; they can climb upon the high ice, whereon I saw them sleep, chiefly when the sun shined, wherein they take great pleasure, but when it is stormy weather they must march off and leave it, for the waves of the sea beat with great violence against it, as if it were against rocks, as I have mentioned already in the chapter of ice.

We saw most of them upon the ice about the west side near to the shoar, where there was an incredible number of them, that if the master of the ship should not catch whales enough, they might lade their ships with seales only; and we have examples that little ships have taken their lading only of them, but it is very troublesome to flea them: nor are they all alike fat at the time when we arrive there.

1 Phoca gronlendice and Ph. fatide. 
By Spitzbergen we see but a few of them, but instead of them there is plenty of sea-horses. Where many seales are seen, that is not a good place to eatch whales in. It seemeth as if they leave but very little for the whale to live upon, because there is so great a number of them. They feed upon small fishes, as far as I could understand; we cut open several of them, and found nothing in their stomachs but great and long whitish worms of the thickness of ones little finger. We come up to them where they lye upon the large sheets of ice; we make a great noise with shouting, which astonisheth them perhaps, or else out of novelty they hold up their noses very ligh, and make a long neck, as our grey-hounds do, and bark. In this fright of theirs we strike them with half-pikes, or long poles upon their noses, and knock them down half dead, but for all that they recover themselves and rise again. Some of them stand upon their defence, bite at, and run after the men; and they rum as fast as a man, and their lame way of going doth not hinder them at all, for they shove themselves along just like an eel. Some run from the ice to the water, and leave a yellow dung behind them, which they squirt out at their hunters, as the hern does: they stink naturally abominably. Others stand in the water with half their belly, and look about them to see what is done upon the ice. When they are going to dive under the water, they hold up their noses and make a long neck: when they jump from the ice under water, and also when they make a dance of seales, as they call it, about the ships, they constantly dive with their heads under water. 'Ihey have their young ones by them, one whereof we took away with us to the ship alive, but it would not cat anything, but did mew just like a eat, and if we touch'd him he would suap at us, so we killed him. The biggest of them that I have secn were from five to eight foot long, out of which we cut so much fat, that we filled half a barrel with it. Their fat is about three or four fingers thick, it covers the flesh just under 
the skin, and we do flea it off as a skin : this fat yiekds the best train-oyl; the flesh is quite black. They have abundance of blood, as if they were only filled up with it. 'They have great livers, lungs, and hearts, which we eat after we have drawn out the rankness with water; we boil them, but this dish is very loathsom, so that I could not eat it, it tasted so of train-oyl. He hath abundance of guts, which are very small: I found no fat within them ; their parts of generation is a hard bone, like unto that of a dog, about a span long, covered with sinews; some were hardly so long as your little finger, and yet they were not young ones neither. 'The crystal of their eye is not of the same colour always, for some were like a crystal, others white, others yellowish, others reddish; they are bigger than a pea; if one will keep them he must let them dry gently, or one may wrap them in linnen rags, and so lay them in a moist place, for else they fly or crack to pieces. I am informed, that when they couple they are very fierce, so that a man dares not come near them upon the ice, then they bring their long boats near the ice, and so kill them ont of the boats. They do not quickly dye when the blood is almost all run out; after they have been mortally wounded and flea'd, they still live, and it looks ill to see them tumble themselves about in their own blood. We had an example of that in him that was eight foot long, for when he was flea'd, and most of the fat cut off, notwithstanding all the blows he had had upon his head and nose, he would still snap at us and bite about him, and took hold of a short pike with his teeth, after such a rate as if nothing ailed him. Then we run a short pike through his very heart and liver, and there ran out as much blood as if it had been a bullock. 'The masters of the ships will not suffer these nasty doings in their ships, for it fouls them mightily. Not only this was so vivacious, but all the rest are the same, for when we thought that they lay dead in our long boats, they snapt about them, so that we were forced to kill them. 
For sports sake I went once along with them upon the ice, and run one through the body with my sword several times, which he did not matter at all; I fell into the snow up to my knees, and he barked at me, and offered to bite me, which I avoided, and when I got up again I ran after him and gave him several wounds more, which he was not concerned at, but ran swifter than I could, and flung himself off from the ice into the sea, and went down to the bottom.

\section{Of the Sea-Horse, called by some the Morse. ${ }^{1}$}

The sea-horse is not unlike unto the seale in the shape of the body, only is much bigger than the other: he is as big as an ox. Their legs are also like those of the seale, for they have five claws as well on the fore as the hinder feet, but they have only short nails: their head is thicker and rounder, and also much stronger. Their skin is an inch thick, chiefly about the neck, covered with short mousecoloured hair, some reddish, some grey, some have but little hair, and are mangy, and full of scars that are bitten, and look as if they were flea'd ; cvery where about their joints their skin is full of lines, as the inside of a man's hand: they have two great and long teeth in their upper jaw-bone, that hang down below their under lips, that are about a foot and two foot long, sometimes they are longer: the young ones have no great teeth at all, but they grow in time as they grow older. All the sea-horses have two firm long teeth; yet I have seen old ones that had but one; it may be that sometimes they loose them when they fight, or otherwise they may fall out of themselves, for I observed that somc of them had foul, hollow, rotten teeth. These two long teeth are estcemed beyond irory, because they are so very white, and are dearer; they are close and firm within, and heavy, but the root thereof is hollow. Of their teeth are made knife-hafts, boxes, \&c. The Jutlanders make buttons for

1 The Walrus or Morse (Trichecus Rosmarus). 
their clothes of the other teetl. Their mouth is very broad before, like a bullocks, whercon grow above and underneath several bristles that are hollow within, and of the bigness of a straw : of these bristles the seamen make rings, which they wear on their fingers for the cramp. Above the nppermost beard they have two semicircular nostrils, whercout he blows the water, like the whale, yet with a less noise. 'Their eyes are at a good distance from the nose; they have eyelids as other fourfooted beasts have; his eyes are naturally as red as blood when he doth not turn them, and I could see no difference when they were moved; for they always turn'd their eyes when they did look upon me, and then they look much uglier, though they are never handsom. Their ears are somewhat higher than the eyes, but very near to them, which are like those of the seales. Their tongue is at least as big as a neat's; when it is but nowly boiled it may be eaten, but if it is laid by for two or three days, it becomes rank like trainoyl. Their neck is very thick, wherefore he does not readily turn his head about, and this is the reason why he turneth his eyes generally. Their tails are short, like those of the seale.

From their flesh we cut no fat, it is all mixed together like unto hogs-flesh, to which it is the likest: their heart and liver we did eat; they taste well enough, chiefly where we have no great variety of dishes. Their yards are of a hard bone, about two foot long, thick at the bottom, and less before, somewhat bent in the middle; at the side towards their belly it is flat, but it is round without, and it is every where covered over with sinews. They turn also knife-hafts and other things out of this bone. What their food is I cannot certainly tell, they may perhaps eat both herbs and fish; that they eat herbs I conclude from hence, that their dung looks like horse-dung: that they eat fish I judge, because when we cut the fat off a whale one of them did often take the skin with him under water; he did also fling it up and catch it 
again. The burgermeister doth eat his dung, as is said before when I writ of the birds. The sea-horses keep generally about Spitzbergen, for amongst the ice-hills I saw none. They lye upon the ice, as I have already mentioned in the first part, by the 12th of July, very nastily, as the seales in great numbers, and roar most terribly. They dive with their head under the water before, like the seales. They sleep and snore, not only upon the icc, but also in the water, so that we take them several times for dead ones.

They are very stout and undaunted creatures; they stand by onc another as long as they have life, and if any of them be wounded they make to the long-boat, notwithstanding that the men strike and cut and push at them; some will dive under the water near unto the long-boats, and cut holes in them with their great teeth under water; and other's without any fear at all make to the boat, and stand up with half their body out of the water, and endearour to get into the boat.

In such a battel a sea-horse did once strike with his teeth or tushes into the boat, and took hold of our harponier with his long tooth, between his shirt and the waistband of his breeches, so that the waistband broke, otherwise he had pulled him under water.

When they roar, if they are imitated, they strive which shall get underneath the water, and fall a fighting and biting one another till they fetch blood: others strive to set at liberty the sea horses taken by the men, striving before each other to get to the boat, biting and gnashing with their teeth, and roaring terribly. They nerer give over so long as one of them is alive, and if you are forced to fly because of their unspcakable number, they will follow the boat till you lose them out of sight, for they cannot follow far, their great number hindring one another. This we found by Weihegat by Spitzbergen, where they got together in great numbers and made our boat take in water, so that we were forced to 
flee; yet they followed us as long as we could sce them, on the 12th day of July. We take them only for their tecth: you shall see almost a hundred of them before you find one that hath good teeth, for some of them are but small, others have but one, and others none at all.

I saw one in the English Haven, lying on a sheet of ice; at first we took him to be a seale, but we found it was an old, bald, and mangy sea-horse. We gave him some blows, which he took, and dived under water. When they see them lye upon the ice, or hear them roar, they row with their boats to them, where they lye in great numbers; but I believe one of them keeps watch, for I have sercral times observed that one of them did strike him that was next to him with his tooth, and so it went on. When they awake they rise up and stand upon their fore-foot, look terribly, and roar, and strike with their long teeth into the ice for madness, and so draw themselves along by the help thereof, when they run apace, or climb upon the ice, as the seales do. Their greatest strength lyeth in their head, and their skin is thickest about the neek; it is thicker than that of an elk, and it is also a great deal firmer; wherefore if they were dressed like an elk's skin, they would serve instead of the best buff coat. When great multitudes of them lye upon a sheet of ice, and they do awake and fling themselves into the sea, you must keep off your boat at a distance from the ice, until the greater part of them are got off; for else they would jump into the boat to you and overset it, whereof many instances have been; then the harponier runs after them on the ice, or he darts his harpoon out of the boat at the sea-horse, who runs on a little till he is tired, then the men draw on the rope or line again, and fetch him to the boat, where he begins to resist to the utmost, biting and jumping out of the watcr, and the harponier runs his launce into him until he is killed. When they dart the harpoon at them, they always take the opportunity to do it when he is precipitating himself from 
the ice, or when he diveth with his head under water, for then his skin is smooth and extended, and therefore the harpoon striketh through the skin on his back the better: but when he lyeth and sleepeth his skin is loose and wrinkled, so that the harpoon doth not pieree the skin, but falls off. The harpoon for a sea-horse, and the launce also, are short, of the length of one span, or one and a half, and an inch thick, and the wooden staff thereof is about six foot long; the harpoon for a whale is much too weak to pierce his thick skin withal, yet both of them are very well temper'd and of good tough iron, and not much hardened. When the sea-horse is killed, they take the head only and leave the rest; this they carry on board, where they cut out the teeth; the two great ones belong to the owners or merchants of the ship, but the small teeth are not esteemed. I eamnot but mention that we went by a field of ice, where so many sea-horses lay, that the weight of them made the ice even with the water; but when they jumped off into the sea, we could hardly step out of our boat upon it, so high was it risen out of the water. It was related to me, by them that used this Greenland trade every year, as a certaine truth, that once when they had no good fortune to catch whales, they rowed with their boats to the Mufs Island, which was full of sea-horses; they rentured upon them couragiously with eutting, striking, pushing, and shouting, so that they killed a great many of them; but when they saw that still more and more of them got together, they laid the dead sea-horses round about them, and stood in the middle of them as in a castle, leaving a place open where the others might come into them, as through a gate; and after this manner they have killed several hundreds of them, and made a good voyage of it; for some years ago their teeth have been in greater estecm than now. 


\section{CHAP. V.}

Of the Crustaceous Fish that I Observed.

I Fouxd two sorts of them, viz., cranfish and starfish; of the craufish I saw four sorts, the sea-spider, as the Frenchmen call them; the red prawn; the small prawn, or the little small shrimp; and the rhale's louse.

'The starfish I put to them also, because they have their arms or legs, wherewith they move themselves, and are incrustated with shells.

1. Of the Sea Crawfish without a Tail, or Sea Spiders. ${ }^{1}$

This sort of crawfish has no tail, but six feet and two claws: they are else very like lobsters in the shape of their body. They are of a dark brownish colour, somewhat prickly on their backs, and hairy all over their body. I have seen many of this kind with six feet and two claws in my voyage to Spain, whereof I have also made a draught in my voyage into Spain (which I shall, God willing, communicate to the curious), but they differ from these of Spitzbergen in their bigness and head; this of Spitzbergen hath a head like a lobster, but the male of them that I saw in my voyage to Spain, made, with its head and tail, just the shape of a lute. I did not eat any of the Spitzbergen sea crawfish, neither have I drawn them at Spitzbergen for want of time, for I thought to have brought them along with me, but they were carried away by the rats. I got them in English Haven on the 19th of June; I afterwards saw them in the North Sea, not far from England, where we bought from the Hilgelund fishermen a great tarbut, in whose stomach we found a sea crawfish two spans long, when its feet were spread out.

1 This may be Lithodes arcticu. 


\section{Of the Garnels or Prawns. ${ }^{1}$}

Betwixt our prawns and those of Spitzbergen is no difference, only that those of Spitzbergen are red before they are boiled. Their head is peculiar, consisting of two parts, with several horns; the whole head is broad; at the encl of the head are the eyes, which stand out as crawfishes do ; he doth not look downwards, but streight before, and sidewards. The scale of his back is like a back piece of armour, which also behind the head, in his neck, is somewhat bended in, and behind it is a prickle. After that follow six plates, like the armour for the arms and legs, and about the brims thereof are small black spots, as if they were the nails of the armour. These plates lye exactly round one upon the other. The tail consisteth also of five parts; when he expands it, it is like the tail of a bird. He hath two claws before, the further part whereof looks somewhat like the phangs of a toothdrawer. He hath eighteen legs, whereof those that are nearest to the claws are the shortest: the first eight legs have four joints, whereof the uppermost is the longest, and the undermost the shortest: they are not hairy at all. The ten hindermost legs, whereof the furthermost are the longest, and the uppermost joint is much thicker and shorter than the lowermost long ones, have but two joints, the feet whereof are somewhat bended under and are hairy. On these hindmost and undermost joints grow out two shoots below, on the rest but one. He shoots very swiftly along in the water: he was as big as I have delineated him, according to the life. They are food for the birds, as I have mentioned before.

1 Crangon Boreas. This prawn, like all the Decapod Crustacea, has but ten legs. Martens ineludes other appendages in his numeration of its legs. 'There is an excellent figure of it in Phipps' I'oyage. 
3. Of the Lesser Garnels or Shrimps. ${ }^{1}$

I have also taken notice, in my voyage to Spitzbergen, of a sort of shrimps that are like worms; the head thereof is like the head of a fly; it hath on the foremost part of its head two horns standing out; it hath scales like the hog-louse; its back is round, and broad downwards; it hath twelve legs; on each side of the foremost scale it hath three legs; after you have told four scales more, there is on each side three legs more; they are no bigger than I have drawn them: the birds eat them as their best food, being always in great numbers where these worms wcre. I found great plenty of them in the Danish Harbour, between and underneath the stones in the water; afterwards, on the eighth of July, I found them in the Mussel Haven. I have also found them in the seed of the whales that swam upon the water.

\section{Of the Louse of the Whale. ${ }^{2}$}

The whale's louse hath no resemblance at all to our lice, except in the head, and therefore it belongs rather to the crustaceous animals : their scales are as hard as those of the prawns; they have a head like a louse, with four horns; the two short horns that stand out before have two knobs, like kettle drumsticks; the two other bended horns are sharp before. Its head hath almost the shape of an acorn ; is cut very deep behind. It hath two eyes, and but one nostril. The neck is not made of stiff scales, but its skin is like that between two scales or plates of a lobster. It hath six plates on the back; the foremost of them is shaped like a weaver's shuttle. The tail might be compared unto a shield, but it is very short. On the foremost plate it hath feet shaped like a scythe; they are round before and bent, like the first quarter of the moon; but on the inside they are toothed like a

\footnotetext{
1 Probably the Anony $x$ Ampulla, figured in Phipls. 2 Cyames ceti.
} 
saw, and at the end thereof there is a sharp point. On each side of the second and third plait grow out four legs, that are his oars; they have a short joint below, wherein these oars are moved; these they lay in a cross one over the other upon their back, when they feed upon the whale; or they put them upwards together, as the vaulters do when they jump over swords; the six hindmost legs are like those of a crawfish; they have three joints on each leg, the foremost whereof are crooked like a half-moon, but before, or on the ends they are very sharp-pointed, so that they can take firm hold of the skin of men as of that of the whale, so that you must cut them in pieces before you can pull them from the skin. $\mathrm{He}$ that will have them alive, must cut the skin of the whale out with them.

'They sit on certain places of the whale's body (as between his finns, on his pudenda, and on his lips), where he cannot easily rub himself, and bite pieces out of his skin, as if the birds had eaten him. Some whales are full of lice, and others have never a one; the warmer the weather is, the more lice they get, as I am informed.

\section{Of the Starfish.1}

I have seen but two sorts of these in my voyage, the first of them have five points or rays, like legs; it is quite otherwise shaped than those I have seen in the North, Spanish, and Mediterranean Seas. It is of a red colour. Above, upon the plain of its body, it hath five double rows of sharp knobs or grains; between each of these double rows is a single row of the same knobs, so that in all there is fiftecn rows of knobs on the whole plain. These fifteen rows together make a star of five outward bended points.

As for the rest, this plain looketh like the back of a spider,

${ }^{1}$ A species of Ophiotepis, the asteries Ophiur'e of Linnasus, Syst. Nat., I, 1100 . 
but if he is turned he looketh neatly; and in this posture is seen in the middle a five-corner'd plain star, which I take to be its mouth, which he can open and draw together like a purse. Round about this star are small black spots in rows, of the shape of a star. Further forwards, about the middle star or his mouth, a broader one is, like unto the flower of the crowsfoot. From the middle star proceed five legs or arms, which have no knobs where they begin, but begin first to hare some behind the flower-like shaped star, on both sides to the end. The knobs between the legs are soft to the touch, like the skin of an egg; their legs are scaly, about three fingers' breadth long, broader at their beginning, where they have knobs, and afterwards by degrees they grow narrower. Between the scales on both sides the knobs come out commonly three or four together, and look like warts. When he swims in the water, he spreads out these knobs on each side, just as a bird doth his feathers when it is going to fly.

\section{Of the Second Starfish. ${ }^{1}$}

Besides this, another fine starfish came to my hands, which rather ought to be called the coralfish, because he is like twigs of coral, for which I took them also, before I perceived that he was alive. This is of a brighter colour than the other, for the other is dark red. Its body hath ten corners, and it hath a star above with as many rays; each of these one may compare unto a sail of the windmills that the children run against the wind withall, or to a piece of such crosses that are broad before, and narrow where they meet together; that is to say of the shape of a dovetail. It fecleth rough : the lower part of the body is very neat; in the micldle thercof is a star with six points, which I take to be his mouth. Abont the mouth he is soft, to the place where his

1 Astrophyton arborescens ("The Medusa's Head"), the Asterias Caput Meduse of Linnæus, Syst. Nat., I, 1101. 
legs begin; between the beginning of his legs he had soft cavities.

His legs are, where they begin, thick, and have in the middle a longish hollow or gutter, which feeleth soft; on the brim they are adorned with scales, that lye one over the other, no otherwise than if they were a row of coral, but underneath the scales are twisted, and have in the middle forwards small black strokes, but the scales lye over one another like unto the plaits of the crawfish. Besides, where the legs come out of the body, they spread themselves double into twigs, and are, as is said before, hollow in the middle, until the place where they divide themselves into several branches, and so grow slenderer by degrees.

The undermost small branches are scaley all round, but not twisted like ropes; they are sharp-pointed on their ends like unto the feet of a spider, wherefore the seamen call them sea-spiders. When they swim in the water they hold their legs together, and so they row along. I had one of this sort that was a span long, from the extremity of one foot to the other; but this I have delineated is less. The biggest are the handsomest for colour. They dye soon after they are out of the water, and when they are dying they bend their legs towards the mouth. The body, when it is dead, soon breaks to pieces, which is the reason that I could not keep the great ones. Rondeletius, in his book of fish, hath delineated one of this shape, but the same is not the same species, for his is black; neither do I find the plaits in his, except he that drew it did not observe them.

Some of both these sorts I got on the fifth of July, before the Weihegat, when a whale made his escape from us, because the line whereunto the harpoon was fastened was entangled about a rock: on this they hung, and so I got them alive. 


\section{CILAPTER ITI.}

BEFore I come to treat of the whale, I think it eonvenient to say something of some finn'd fishes, which I met withal in my royage to Spitzbergen, some whereof are propagated by the shooting of their Row, and others bear and bring forth their young alive.

I will begin with the first kind, whereof the first that I met withal was the fish that we eall macarel.

\section{Of the Macarel. ${ }^{2}$}

This fish is like unto a herring in his shape, but hath on his back a large fin, and some what below it a very small one. Then lower there is another greater and broader one, but not so high as the mppermost. Underneath this are five small ones, that are all of the same bigness, and at equal distances from one another. Tery near to the tail there is another less one; so that on the whole back there is two great ones and scren little ones. Near unto the gills is a finn on each side. Underneath the belly there are again on each sicle one almost of the same bigness of that that is near to the gills. Underneath, towards the tail, is one of the same bigness of the third on the back. Behind this there are again five of an equal bigness; and below that a still less one; so that those of the lower part of the back are equal to those of the lower part of the belly. Their head is like unto that of a herring. He hath a great many small holes on the cover of his gills, and also underncath the eyes. They have a great variety of colours, that look more glorious when they are alive than when they are dead, for when they are dying the colours fade and grow pale. From his back towards the side he hath black stroaks. The uppermost part of his baek

1 Roe.

2 Scontier scomlinus, the common mackarel. 
is blue till to the middle, and the other half underneath it is green, as if some blue did shine through it. Underneath his belly he is as white as silver, and his finns are white every where. All the colours of this fish shine like unto a silver or golden ground, done over with thin transparent or illuminating colours. Their eyes are black. It is the beautifulest fish of all that I ever saw. This that I describe here was catched in the North Sea, afterwards, on the 2ith day of June 1673. We did catch some macarels behind Scotland, by the Island of St. Kilda, which were half blind; it is occasioned by a black skin that groweth over their eyes in the winter, and cometh off again in the beginning of the summer. We do not see them in the winter, for they run toward the north; in the summer we see them in the North Sea, and I have seen them also in Spain. We caught them after the following manner: we fastened a bullet, that weighed about two or three pounds, to a line, about a fathom distance from the end, whereon we had fastened a hook; this hook we baited with a piece of red cloth, and so we flung it into the sea, and towed it behind our ship; then when the macarel doth swiftly shoot at it, he bites upon the hook and so is hung, which you presently perceive by its pulling, as you do when you catch any other fish, notwithstanding that the rope of its own accord doth pull or draw very hard, by reason of the sea, so that if you should rowl it about your hand it would benumb your hand in a little time to that degree that you would not be sensible if one should cut it; wherefore they tye their ropes to the carved work on the stern of the ship, so that sometimes many of them are tyed to the ship by one another, where the ships sail apace; but this doth hinder the ship very much in its sailing, and I dare say two such ropes draw as much as a man's strength. They catch them also with herring, with a piece whereof they bait the hook, at which they bite sooner than at a red piece of rag or cloth. They eat best if you boil, or broil, or roast them 
fresh as they are caught, or dry them : they arc hard to be digested.

\section{Of the Dragon-Fish. ${ }^{1}$}

It is peculiar to this fish to have two finns on his back, the foremost whereof hath very long strings, about two inches high abore the back: the hindmost finn of the back is not so high, but yet it goeth a great way all along the back, and hath no such strings. He hath no gills; in the room of them lie liath two blowing holes in his neek, and on each side of these holes are two short finns, and underneath these on each side a broad one; underneath his belly he hath a long very narrow fim, that reaches to the tail. His head is oblong, composed of many bones; he hath before on his nose a rais'd part; his tail is about an inch broad; his body is long, thin, and roundish, of a greyish silver colour and shining; his shape is likest to that of a young hay, as well the head as the rest of the body. 'They are caught between the Bears Island and Spitzbergen. We got one off of Hitland, when our cook flung out his bucket for water, in which he took up one, with some small fish of the shape of an herring, but they were not bigger than a joint of your little finger. Our seamen informed me of some other small fish, that are in the deep holes between the high mountains, in the South Haven.

\section{Of the Dolphin. ${ }^{2}$}

This is also a common fish, because we see them in great numbers every where in the sea, chiefly before a storm or hard weather, for then they jump in great numbers out of

1 This may be a young specimen of the Chimera monstrosa, a cartilaginous fish allied to the shark ("hay"), with which Martens compares it.

2 The dolphin (Delphinus Delphis). For detailed accounts of the different species of Cetacea, see Dr. Gray's "Catalogue of the Mammalia in the British Musenm," lart i. 
the sea, like seales. 'The head of it, chicfly the nose, is very like that of the place's head. Its mouth is full of little sharp teeth. He hath a finn on the middle of his back, which is hollow'd out towards the tail, like an half-moon. On its belly are two finns, like those of the whale; these finns are not like those of small or little fishes, that are bony, join'd together with a thin skin, but they are all over fleshy, and covered with a thick skin, and made of jointed bones within. The tail is broad, and of the same shape as that of the whale, but it is not cut in, and is crooked from one end to the other, like a sickle. He hath two small round eyes. The greatest part of the body is of a black colour, but the belly is white. 'They are five or six feet long. They run very swift against the wind, as an arrow : they are generally caught by chance. Because figures thereof are in other books, I did not think it convenient to delineate him.

\section{Of the Butskopf, or Place's Head.'}

'The butskopf's head is blunt beforc, where on is a bill or' beak of an equal bigness all along, which distinguishes him from the dolphin, which is thicker behind and more pointed before. 'The finns are like those of the dolphin, but the foremost on his belly are liker those of the whale; its tail is also liker a whale's. He hath a spout hole above in his neck, whereout he spouts the water, but not with such strength nor so high as a whale doth. There is also a difference in the sound of the fishes; for this, when he bloweth out the water, makes but a small noise; but the blowing of a whale roareth that you may hear it afar off. His eyes are very small in proportion to his bigness. I have seen them sixteen, eighteen, and sometimes twenty feet long; their back is of a brown colour; the head brown and marbled; underneath their belly they are white. They run very near unto

1 'This may be the IIyperoodon Butzkopf; the Bottle-head, a small whale, which has once or twiec been stranded on our consts. 
the ships, so that one may push at them with a stick; and they keep up with a ship for a long time, which other fishes do not, for when they see the ships they are afraid of them : they all swim against the wind, as whales, finn fish, and dolphins. I am of opinion that they endeavour to run away from the storm, and that they find some pain or other in their bodics some days before, for you shall see some fish tumble about strangely in the water, which $I$ do not take to be playing, and this generally continues until their tormentor, the east wind, ceases. We saw another sort of great fishes, that might rightly be called butskopf, for their head is quite blunt before, and have a finn that stands up three times higher than the other butskiopf has; they are somewhat of a dark brown colour, but of the same bigness. We saw them tumble several times out of the water; one might casily take them, because of their high finn that stands on the top of their back: they are not sword-fish, nor of the same kind we call tumblers, which we see between the Elbe and Hilgeland.

\section{Of the White-Fish. ${ }^{1}$}

I do not by this name mean the fish we call so here in our country, that are but small, but I mean a bigger sort, as large as a butskopf, in shape like a whale, and without finns on his back; he hath two finns on his belly, as I am informed by others that have caught them. The tail is like unto a whale's: he hath a spout hole on his head: he hath also an hoffel on his head like a whale. He is of a yellowish white colour. He hath fat cnough in proportion to his bigness: I was told by them that had caught one, that they did fill a barrel of fat from one; but this fat is very soft, and the harpoon easily breaks out, wherefore they do not care to catch them.

x 'The Belugu Cutodon Gray; the northeru Beluga, a species which lout seldom visits the British seas. 
When we see plenty of them, the skippers say it is a sign of a good year for catching of whales, for if these find good food, the whales find the same also. We saw on the 19th of June some hundreds of them.

\section{Of the Unicorn. ${ }^{1}$}

The unicorn is but seldom seen in these parts, neither had I the good fortune to meet with one in all my voyage; and yet sometimes many of them are seen. I do not find that the cuts that I have seen in some books agree with the description that I have heard thereof; for I was informed that he hath no finn on his back, as he is drawn; he hath also a spout hole in his neck. When they swim swiftly in the water they say that they hold up their horns, or rather teeth, out of the water, and so go in great shoals. 'The shape of their body is like a seal; the undermost finns, and the tail, are like unto those of the whale. The skin of some of them is black, some like a grey dappled horse ; underneath their belly they are white. They are from sixteen to twenty feet long. 'They swim very swiftly, that although they are seen, yet they are but seldom caught.

7. Of the Saw-Fish, sometimes called the Sword-Fish. ${ }^{2}$

'This fish has his name from a saw, which is a long broad bone fixed to his nose, that hath on each side many pointed tecth or peggs, like a comb. IIe hath two finns on his back, the uppermost of them is like the butskiopf's, the undermost hath behind, towards the tail, a hollowness like unto a sickle. Underneath his belly he hath four, on each side two, the uppermost thereof towards the head are the broadest and longest, but the lowermost are somewhat shorter and nar-

1 The Narwhal (1/onodon monoceros).

2 Pristis antiquorum; the Saw-fish, a fish belonging to the same order as the sharks. 
rower; they stand dircetly underneath the uppermost finns of the back. The tail is like unto a piece of board whereon the dyers widen or stretch their stockins, which is pointed behind and underneath: the tail is not divided, etc. Towards the undermost finn of the back the tail is thinner. 'The other shape from the top to the tail is like a man's naked arm; the nostrils are oblong; the eyes stand high out of his head: their mouths are just directly underneath the eyes; they are in bigness from two to twenty foot.

These saw or sword-fish are great enemies to the whale and finn-fish. Many of them gather about him, and they do not leare the whale until they have killed him ; then they eat of him only the tongue, all the rest they leave behind them, as doth appear by the whales that are killed by the surord-fish. I saw myself, in our home-royage or return, a fight between a whate and a sucord-fish, where both of them made a great bustle, beating and jumping about; and I understood that in calm weather the scamen let them alone until the whale be killed, where they takc him without any trouble. But if they set out their long boats after the whale, they frighten the suord fish, and so the whale escapes.

\section{Of the Hay. ${ }^{1}$}

There are several sorts of them : they have two finns on their backs, the highest whercof is like to the uppermost of the butsliopf, but the lowermost is of an equal brcadth at the top and bottom, but it is hollowed out like a sickle: he hath six fimns underneath his belly, whereof the foremost two are the longest and shaped like a tongue, but the two middlemost are somewhat broader than those towards the tail, and of the same shape; the two last, underneath by the tail, are

1 Shark: the species most abundant in the Arctic regions seems to be the Dalatias borealis or Northern Shark. What Scoresby figures as an appendage of the eye, is a parasitic crustacean of the family Lerneida. 
of an equal breadth from top to bottom, something shorter than the middle ones. The tail is of a peculiar shape, like unto one halfpart of that of the sword-fish, but it is split below, and the other part is like a leaf of a lilly. He hath a long nose. The whole fish is long, round and thin, and he is thickest towards the head; his mouth is shaped as that of the sword-fish; it is full of sharp teeth, three upper and three under rows, one by the other: his eyes stand something more out before than behind, after the same fashion as those of the sword-fish; they are oblong, and very clear: he hath five gills on each side, as the suord-fish; his skin is hard and thick, and rough if you touch it or strike it upwards; it is of greyish colour; they are from one fathom long to three; it is a very derouring fish, and bites great pieces from the whale, as if they had been dug out with shovels. They devour of many whales all the fat underneath the water, and this is the reason the scamen say, They hare caught half a whale that was dead. And the birds do help them also, and what is not taken away underneath ferments out of the top. They have a large liver, whereof they make oyl. Out of their backs we cut the flesh, which we hung up for some days in the open air; then we boil and roast it, and this tasts very well when we have nothing that is better. They do not fling away the hays in Spain, but sell them: the little ones are the best: they are very eager after man's flesh, and eat many a man that goeth to swim or wash in the sea, whereof we have many instances. They are easily caught after the following manner: we take a great hook fastened to a strong iron chain, baited with a piece of flesh, and let it hang down into the sea; the hay, as soon as he doth perceive it, snaps it, and is catch'd ; but when the hay perceives that he is fast, he doth use his utmost endearour to bite off the hook, which he cannot for the iron. 


\section{CHA P T ER V I I.}

Of the Whale. ${ }^{1}$

THe fish properly called the whate, for whose sake our ships chiefly undertake the voyage to Spitzbergen, is differing from other uhales in his finns and mouth, which is without teeth, but instead thereof long, black, somewhat broad and horny flakes, all jagged like hairs: he differs from the finn-fish in his finns, for the finn-fish hath a great finn on his back, but the whale, properly so ealled, hath none on his back: and there is two finns behind his eyes of a bigness proportionable to the whale, covered with a thick black skin, delicately marbled with white strokes; or as you see in marble, trees, houses or the like things represented. In the tail of one the fishes was marbled very delicately this number, 1220, very even and exact, as if they had been painted on it on purpose. This marbling on the whale is like veins in a piece of wood, that rum streight through, or else round about the center or pith of a tree, and so go both white and yellow strokes, through the thick and the thin strokes, that is like parchment or vellam, and give to the whale an incomparable beauty and ornament. When these finns are cut up, you find underneath the thick skin bones that look like unto a man's hand, when it is opened and the fingers are expanded or spread ; between these joynts there are stiff sinews, which flye up and rebound again if you fling them hard against the ground, as the sinews of great fish, as of a sturgeon, or of some four footed beasts generally do. You may cut pieces of these sinews of the bigness of your head; they squeeze together when thrown on the ground, and so rebound rery high, and as swift as an arrow from the string of a bow. 'The

1 Bulone mysticetus; the Right Whale. 
whale hath no other finns but these two wherewith he steers himself, as a boat is rowed with two oars.

'Their tail doth not stand up as the tails of almost any other fish, but it doth lye horizontal, as that of the fim-fish, butsliopf, dolphin, and the like, and it is three, three and a half, and four fathoms broad. The head is the third part of the fish, and some have bigger heads; on the upper and under lip are short hairs before. Their lips are quite plain, somewhat bended like an $\mathrm{S}$, and they end underneath the eyes before the two fins. Above the uppermost bended lip he hath black streaks, some are darkish brown, and they are crooked as the lips are. Their lips are smooth, and quite black, round like the quarter of a circle; when they draw them together they lock into one another. Within, on the uppermost lip is the whale-bone, of a brown, black, and yellow colour, with streaks of several colours, as the bones of a finn-fish. The whale bones of some of the whales are blew, and light blew, which two are reckoned to come from young whales. In the other cutt, where the mouth is shut up, you do not see the whalebone. Just before, on the under lip, is a cavity or hole, which the upper lip fits exactly into, as a knife into a sheath. I do really believe, that he draws the water that he bloweth out through this hole, and so I have been informed also by seamen. Within his mouth is the whalebone, all hairy as horse's hair, as it is also in the finn-fish, and it hangs down from both sides all about his tongue. The whalebone of some whales is bended like unto a cimeter, and others like unto a half-moon.

The smallest whalebone is before, in his mouth, and behind, towards his throat, and the middlemost is the greatest and longest; it is sometimes about two or three men's lengths, from whence you may easily conjecture how large this fish must be. On one side, all in a row, there is two hundred and fifty pieces of whalebone, and as many also on the other side, which maketh fire hundred in all; and there 
is more over and above this number, for they let the least whalebone of all remain, because they cannot well come at it to cut it out, because it is very narrow where the two lips meet together. 'The whalebone is in a flat row, one piece by the other, somewhat bended within, and towards the lips every where like a half moon. The whalebone is broad at the top, where it sticketh fast to the upper lip, every where over grown with hard and white sinews towards the root, so that between two pieces of whalebone you may put in your hand. These white sinews look like boiled sea-catts or black-fish (in Spanish called Cattula la Mar); they are of a pleasant smell, so that we might eat of them; they are not tough at all, but break as easily as cheese, but they did not taste so well; when they putrify or rot they smell horribly, just like unto a foul or rotten tooth. Where the whalebone is broadest, as underneath by the root, there groweth small whalebone, the other greater, as you see small and large trees one amongst the other in a wood. I believe the small whalebone doth not grow bigger, as one might think that some of the great pieces thereof might come out, and that so this small whalebone might grow up again in the room thereof, or as in children the hair grows again when cut off; but it is not so, for this whalebone is quite another sort, for it is from one end to the other of an equal thickness, and full of long jacks like horses hair. The whalebone is underneath narrow and pointed, and all over grown with hair, that it may not hurt that that is young: but without the whalebone hath a cavity, for it is turned just like unto a gutter, wherein the water runs, where it lyeth one orer the other, as the shields or plaits of crawfish, or the pantiles of an house that lye one over the other, for else it might easily wound or hurt the under lips. I am of opinion that one might use whalebone in any thing that we use boards for, for they make of whalebone, boxes, knife-hafts, walking sticks and the like. I should think that out of the hair of 
the fish might be made something, as the Spaniards do out of the wild Sempervive aloes (by them called Savila); they prepare it like flax or hemp, and so make packthread, cloths, and the like manufactures of it. ${ }^{1}$

To cut the whalebones out is also a peculiar trade, and abundance of iron tools belong thereunto. The lower part of the whale's mouth is commonly white: the tongue lyeth amongst the whalebones; it is very close tyed to the undermost chap or lip; it is very large and white, with black spots at the edges. It is a soft spongy fat, which cannot easily be cut; it makes a great deal of work to the eutter (for so they call the man that doth cut the fat into small pieces with a large knife, which cannot be well done with other knifes, because it is tough and soft), wherefore they fling the tongue array, else they might get five, six, or seven barrels of train-oyl out of it; but as I said before, they fling it away because of its softness; and this is the most pleasing food for the sword-fish. Upon his head is the horel or bump before the eyes and finns: at the top of this bump on each sicle, is a spout-hole, two over-against one another, which are bended on each sicle like an $\mathrm{S}$, or as the hole that is cut on a violin, whereout he doth blow the water very fiercely, that it roars like a hollow wind which we hear when the wind bloweth into a cave, or against the corner of a board, or like an organ-pipe. 'I'his may be heard at a lcague's distance, although you do not see him by reason of the thick and foggy air. The whale bloweth or spouts the water ficrest of all when he is wounded, then it sounds as the roaring of the sea in a great storm, and as we hear the wind in a rery hard storm. Behind this bump the vhlule is somewhat more bended in than the fim-fish, yet when they swim you cannot well discern one from the other, except you observe it very exactly, for it is only the finn on the fim-fishe's back, that

I See Dr. Gray's "Catalogue of Cetacea in the British Museum," pl. $10,11,12$, for much valuable information on whalebone. 
distinguishes him from the rhale. The head of the whale is not round at the top, bit somewhat flat, and goeth down sloaping, like unto the tyling of an house, to the under lip. The under lip is broader than the whale is in any part of his body, and broadest in the middle; before and behind it is something narrower, according to the shape of the head. In one word, all the whole fish is shaped like unto a shoemakers last, if you look upon it from beneath. Behind the knob or bump where the finus are, between that and the finns, are his eyes, which are not much bigger than those of a bullock, with eyelids and hair, like men's eyes. The crystal of the eye is not much bigger than a pea, clear, white, and transparent as crystal ; the colour of some is yellowish, of others quite white. The seale's are three times as big as those of the whale. The eyes of the whale are placed very low, almost at the end of the upper lip. Some bring along with them from Spitzbergen some bones, which they pretend to be the ears of the whale; but I can say nothing to this, because I never saw any ; but thus much I do remember, that I have heard them say that they lye very deep. The whale doth not hear when he spouts the water, wherefore he is easiest to be struck at that time. His belly and back are quite red, and underneath the belly they are commonly white, yet some of them are coal black; most of them that I saw were white. They look very beautiful when the sun shines upon them, the small clear waves of the sea that are over him glisten like silver. Some of them are marbled on their back and tail. Where he hath been wounded there remaineth always a white scar. I understood one of our harpooniers that he once caught a whale at Spitzbergen that was white all over. Half white I have scen some, but one above the rest, which was a female, was a beautiful one: she was all over marbled black and yellow. Those that are black are not all of the same colour, for some of them are as black as velvet, other's of a coal black, others of the colour of a tench. When they 
are well they are slippery as an eel, but one may stand upon them, because they are so soft that the flesh thereof giveth way to our weight: and the outward skin is thin, like parchment, and is casily pulled off with ones hands when the fish grows hot. I know not whether the skin is thus burnt by the inward heat of the fish when he lies dry a floating upon the water. The sun beams seem not to have so great power as to dry the skin so. We found our first whale so much heated by his hard swimming that he stunk alive; we could pull off great pieces of the skin of the length of a man, which we could not do to other fishes that were not so much heated: but from whales that have been dead some days and are dry, where also the sun shines upon them, or when it doth not rain, one may pull off a great deal of the skin, but it stinks basely of train-oyl or fat, that ferments thro' the pores of the skin. I know not what use to make of this skin, but I have seen women tye their flax with it about the distaff.

The whale loseth its beautiful colour when it groweth dry, for before there is more black amongst it, which maketh the white shew the better; neither doth the black look so well after it is dry, for it groweth then brownish. When you hold the skin against the light you see many small pores in it, where the sweat cometh through.

The yard of the whale is a strong sinew, and according as they are in bigness, six, seven, or eight foot long, as I have seen myself. Where this yard is fixed the skin is doubled, so that it lies just like a knife in a sheath, where you can see nothing of the knife but only a little of the haft. The part of generation in the female is just shaped like as that of four legged beasts. At the sides of pudendum stand out the two breasts, with nipples on them like unto those of cows: some of these breasts are quite white, some are speckled with black and blew spots, like a lapwing's egg. When they have no young ones they have but small breasts. I am informed, when they couple together they stand upright, elose to one 
another, with their heads ont of the water ; which seemeth very probable, because they cannot keep long under water, and chiefly in such a heat. They say, that they have but two young ones at a time, for they have never found more than two young ones within them. How long they carry their young is not easily determined; some say they go as long as a cow; but it is very uncertain, he that will believe it may. The sperm of a whale, when it is fresh, smells like wheaten flour when it is boiled in water; when it is still hot it is very white, one may draw it out in threads like hot sealing-wax, glew, or the like; when it groweth cold it turns to a musk-colour and smells strong, and little red worms grow in it. I have try'd several ways to keep this sperm sweet and fresh, but I could never make it like the spermacati which the apothecaries sell in their shops. One may dip of this sperm whole pails full out of the water, for as well this, as that of the sea-horses and seals, swim upon the sea like fat, and we see abundance of it in calm weather, so that it doth make the sea all foul and slimy. I try'd to dry this sperm of a whale in the sum, and it look'd like snot, and when the thin slime was dry'd away from it, look'd like unto Fila metcorica, save only that they are thicker and more heary. Another parcel I boil'd in sea-water, just as I took it out of the water, until the water was evaporated from it; then I had some sea-salt and a nasty brown slime. The third parcel I boil'd in fresh water, and afterwards again in sea-water, the longer I kept it afterwards the more it stunk and the harder it grew. The fourth parcel I intended to keep in the salt water with an intention to carry it along with me to Hamburgh, but it dissolved in the water like glew, and the water became foul and stinking, so that I could by no means make it like the sperma-cati of the apothecaries. Where the yard doth begin it is fon-square, consisting of many strong sinews; if you dry them they are as transparent as fish glew; out of these sinews the seamen 
make twisted whips. Their bones are hard, like unto them of great four-footed beasts, bnt porous, like unto a spunge, and filled with marrow; when that is consumed out, they will hold a great deal of water, for the holes are big, like unto the wax of a honey-comb. Two great and strong bones hold up the under lip, they lye one against the other, and both of them make a figure like unto an half-moon, but one alone by itself maketh a figure like to the quarter of the moon. Some of these bones I saw at Spitzbergen lying on the strand, about twenty foot long, of a very white colour, as if they had been calcined. Our seamen bring some of these along with them home, to shew us how big some whales are, which are already whitened to their hands; for those that come fresh from a whale stink abominably, because of the marrow that is in them. Their flesh is coarse and hard, and it doth look like that of a bull : it is intermix'd with many sinews; it is very dry and lean when it is boiled, because their fat is only between their flesh and skin: some looks green and blue as our powder'd beef, chiefly where the muscles meet together; if one lets it lye a little, it grows black and stinking. The flesh of the tail boils tenderest, and is not quite so dry as that of the body. When we have a mind to eat of a whale, we cut great pieces off before the tail where it is four-square, and boil it like other meat; good beef I prefer far before it, yet rather than be starv'd I advise to eat uhale's flesh, for none of our men dyed of it, and the Frenchmen did eat almost daily of it; they fling it sometimes on the tops of their tubs, and let it lye until it is black, and yet they eat it for all that. The flesh of the $x$.hale, as well as that of the seales, is alone by itself, and the fat at the top thereof, between the flesh and skin. It is about six inches thick on the back and belly, but I have also seen it a foot thick upon a fimn, according as they are great or little fish. The fat of their under lip is thicker than two foot, and is the thickest of all the vhale. 'The tongne, as I 
have said before, is fastened to it, but very soft; but it costs too much labour to cut it out. 'The fat of some whales is much thicker than that of others, as it is with other animals or men, where one is much leaner than another. In the fat zre little sinews interspers'd, which hold the oyl, as a sponge doth water, which one may squecze out. The other strong sinews arc chiefly about the tail, where it is thinmest, for with it he turns and winds himself as a ship is turn'd by the rudder; but his finns are his oars, and according to his bigness he rows himself along with them as swiftly as a bird flics, and doth make a long track in the sea, as a great ship doth when under sail, so that it remains divided for a while.

The vthales of the North Cape (they are so called because they are caught between Spitzbergen and Norway) being not so big, therefore do not yield so much fat as those of Spitzbergen, for of those of the North Cape you shall not fill above ten, twenty, or thirty cardels of fat; the middling sort of those of Spitzbergen yield commonly seventy, eighty, or ninety, and they are about fifty or sixty foot long. Our biggest whale was fifty-three foot long, and we cut off him as much fat as filled seventy cardels; his tail was about three fathoms and a half broad. The skipper, Peter Peterson, of Friesland, informed me that they found a dead whale, whereof they did cut as much fat as fill'd one hundred and thirty cardels; his tail was three fathom and an half broad, but he was not much longer than our biggest, as onc may guess by the tail also, yet much thicker and fatter ; from whence one may infer that they do not grow much longer, but only in thickness or fatness, as we daily see. Nor did I ever hear that a bigger or fatter whale was ever caught, and even those but seldom, for if there were many such our ships could not hold so much as is cut from ten, fifteen, or twenty whales, as some of them have sometimes taken in.

Over the fat is, besides the uppermost thin skin already described, another skin of about an inch thick, proportion- 
able to the bigness of the whate; it is color'd according to the colour of the fish; if the fish be black, this undermost thick skin is so; if the outmost skin that is like parchment is white or yellow, the thick one underneath it is of the same colour. This thick skin is not stiff nor tough at all, so that one might dress it like leather, but it dries just like unto the fungus that grows on elder, which we call Jews-ears, which are thick and turgid when they are green and fresh, but brittle when they are dried; wherefore this skin is not esteemed at all. This and the uppermost skin that covers this, are the occasion that the vhale, which I take to be strongest and biggest of all creatures in the water, cannot make use of his strength, because they are too soft to do much.

I have nothing to relate of the inward parts of the whale, but only that his guts seem to be of a flesh colour; they were full of wind, and the dung that was within them was yellow.

The food of the whale, as it is believed, are the small sea snails, whercof I have made mention in another place, which some take for spiders ; ${ }^{1}$ whether these afford such great nourishment I cannot exactly tell. Some say that they live only by the wind, but then methinks they must have nothing in them but wind, which I found otherwise. I was informed by other's, that about Hitlend a small whale was caught, that had about a barrel of herrings in his belly. They are smaller whales than those we eatch at Spitzbergen, but there is more danger in catching of them, they being less and nimbler than the great ones, to whom the water does not so easily give way as to these, for they jump and play in the water, and keep their tail commonly above water, so that one dare not come near them to lannce them. Concerning the whale's valour, we do find that he is not very courageous, according to lis strength and bigness; for if he sees a man or a longboat he goeth under water and runs away. I did never see nor hear, that out of his own malice he endeavour'd to hurt

1 Clio borealis and Limaciner arctica. 
any man, but when he is in danger; what then he doth is of necessity, and then he doth not value a man no more than a sand nor a long-boat, for he doth beat them all into splinters. His strength may be guessed by the fishermen that eateh with great nets other fishes, when they are going to draw their nets towards the land, what a great strength they must use, which is nothing at all to be compared to his strength. 'The whale doth swim sometimes away with some thousand fathoms of rope-line, swifter a great deal than a ship can sail, or a bird can fly, so that it makes their heads giddly; yet a great ship is too many for him, for although he should strike against it with his tail, yet it doth him more hurt than he doth the ship.

The whales licep in the spring westward from Spitzbergen, near Old Greenland and the Island of John Majen, then they run eastwards to Spitzbergen: after them come the finn-fish, and then there is no more whales seen. It is probable they go after a tolerable cold place; for after that I have seen finn-fish in the Spanish Sea, in the year 1671, in the month of December, and in the year 1672 in Jamuary, and also afterwards in the year 1673 in the Straights of Gibralter in March, and also in the Mediterranean.

He swims against the wind, as all other whales or great fish do. The sword-fish is his mortal enemy; he might rather be called comb-fish, because his long tooth is on each side full of teeth or prickles, most like a comb. In our home-voyage to Hamburg I saw an example of this enmity of a North-caper whale and a sword-fish, near to Hitland; they fought and struck at one another so vehemently that the water flew about like dust, sometimes onc, sometimes the other was uppermost; the weather was a little stormy, or clse we had stay'd to see the end of the battel, so we were forc's to leave them. The dead whale kill'd by the sicordfish stinks at a great distance, but not presently, and those that have been wounded some days before they are caught 
smell the worst, and drive high above the sea water, when others drive eren with the water, and some sink.

The whales have, as well as other beasts, their peculiar distempers and ailments, but I can only write of what I know by hear-say. An ancient and experienced harpoonier informed me, that he did once catch a whale that was very feeble, and that all his skin, but chicfly near unto the tail and finns, hung like films, as if they were old rags dragg'd along behind him, and that he was quite lean; so they made but very little train-oyl of his fat, for the fat was quite white, and light withal as an empty honey-comb. Before a tempest they beat the water, that it doth fly about like unto dust, with their tail; but they have the greatest strength when they strike sidewards as if they did mow, so that one might think that they were in a great agony and a dying. They are mightily tormented by the lice, ${ }^{1}$ whercof I have treated more at large above. The wounds that are given unto the whate by the harpoons, into the fat, heal up again of their own accord, for the salt water cannot stick on it. Many such fishes are caught that have been struck by others with a harpoon, and are heal'd up again, and so have white scars.

\section{CHAP. VIII.}

\section{Ilow they Catch the Whale.}

First, it is to be observed, that when it is like to be a good year to catch whales in, there is many white fish to be seen before; but where we see many seales, there we do not expect to meet with many whales; for they say that they eat uip the food of the whale, wherefore the whales will not stay in such empty places, but go to find out better, and so come 
to Spitzbergen; for there, at the shoar, we see great plenty of the small sea-suails, and perhaps some other small fish. 'They are caught after the following mamner. When they see whales, or when they hear them blow or spout, they call in to the ship, "Fall, fall"; then every body must be ready to get into the long-boat that he doth belong to, commonly six men go into every long-boat, and sometimes seren, according as the long-boats are in bigness; they all of them row until they come very near unto the whale; then doth the harpoonier arise, who sits always before in the boat, where the harpoon, or the sharp iron made like unto an arrow fixed to a stick, doth also lye on the foremost board of the long-boat, which the seamen call the staffen, that is, the broad piece of wood that cometh up from before the boat from the bottom, and stands up higher than all the rest. But when the whale rums streight down towards the bottom underneath the water, then he doth draw the rope very hard, so that the upper part of the long-boat is even with the surface of the water; nay, he would certainly pull it down to the bottom if they should not give him rope enough. This he doth commonly where the sea is deepest; and this doth require an incredible force to draw so many hundred fathoms of rope nnder water. This gives me occasion to remember, that when we, on the 2ith of Aprit 16r2, did fling out our lead near St. Filda, behind Scotland, into the sea, where it was one hundred and twenty fathom deep when the weather was calm, and when we would pull it up again it was so heary that twenty men had much to do to heave it. The harpoonier taketh his harpoon, and holds the point or the iron thereof, together with the fore-rumner, towards his left hand; this is a rope or line of five or seven fathom long, about an inch thick, and is laid up round like a ring, that it may not hinder the harpoon when it is flung; for as soon as he doth fling or dart the harpoon this line follows, for it is more plyable than the rest that are fastened to it, wherewith 
they pursue the whale. It is made of the finest and softest hemp, and not daub'd with tarr, but it doth swell in the water, and so it grows hard. The harpoonier darts his harpoon with the right hand at the fish. When the viale is hit with the harpoon, all the men that are in the long-boat turn themselves about and look before them, and they lay their oars nimbly upon the sides of the long-boat. There is a man in the long-boat, whose business it is to look after the rope; for in each of these long-boats there is a whole heap of lines, between the two seats or benches; this heap is divided into three, four, or five parts, and each of them is of eighty, ninety, to one hundred fathoms long; the first of them is ty'd to the fore-runner or small line; as the whate runs under the water, they tye more and more line to it, and if in one boat there shonld not be enough, they make use of those that are in the other long-boats. These ropes or lines are thicker and stronger than the fore-runner, and are made of strong and tough hemp, and are tarr'd over. The line-furnisher, or the man that doth look aftcr the ropes, and also the other men that are in the long-boat, must have great care that the ropes or lines may not be entangled when they run out so swift, or that they may not run towards the side of the long-boat, for then the long-boat would be overset and many lose their lives, if other long-boats were not near to their assistance. The line must run just before, in the middle of the long-boat, that is called the stave by the seamen, and by reason of this strong and violent motion the wood and rope would be set on fire; but to prevent this the harpoonier hath a wet rag ticd to a stick (like unto a mop) reacly at hand, wherewith he wets the wood without ceasing. The other three men that are in the long-boats take also care of the lines, as well when they are let out as when they are taken in again; and when they cannot hold it with their hands, they wind it about the staves of the boat, and so they do stop it from going any further. Another, that is called the stecrs- 
man, stands behind in the long-boat, and stecrs the boat with an oar, and he takes great care and minds the rope to see which way it runs out; for if it doth go towards either side, and doth not rum just before over the stare, he so guides the boat that it may run exactly out before. The whale runs awa with the long-boat as swift as the wind. If the harpoonicr can, he doth dart the harpoon just behind the spouthole of the whale, or in the thick fat of his back, where they also do launce him, for that maketh him spout blood sooner than if wounded in any other place, and dye sooner than if you should launce them into their belly or through the guts. 'The first whale we caught spouted blood in such a quantity, that the sca was tinged by it wherever he swam, wheremto the mallemuckis flock'd in great numbers, as I have mentioned before. They also launce the whales near their privyparts, if they can come at it, for if they are run in there it doth pain them very much; nay, even when they are almost dead, if you run in your launce thereabouts, it causeth the whole body to tremble. For the most part they do not much mind where they launce or push them, for there is no time to take great deliberation, but they strike at him as well as they can. But about the head the harpoon can do him no hurt, because the fat is but very thin there upon the bones, which the whales know as well as we; for when they find themselves in danger, so that they cammot escape the harpoon, they rather leave their head than their back undefended, for there the harpoon breaks out easier, and so the whale gets away, like one that hath no mind to fight any longer. The use of the harpoon is to tye, as it were, the whales with them, that they may not run away. It is shaped like an arrow before. It hath two sharp beards; they are sharp at the edge and have a broad back, like a hatchet, that is sharp before and blunt behind or on the back, so that it may not cut with its back, for else it would tear out and all your labour would be lost. The iron handle is thicker be- 
hind than before, and it is hollow, whereinto they put the stick. Before this hollow part the fore-gocr is fastened or tyed, that is to say the foremost rope. Those are the best harpoons that are made of clean and fine steel and are not hardened too much, so that you may bend it without snapping; for oftentimes two hundred pounds are lost (for a midling whale is csteem'd at so much) in a minutes time for want of a good and well temper'd harpoon. The wooden stick is fastencd within the iron collet or funnel of the harpoon with packthread, wound all about the iron ; somewhat higher up, about two spans off, there is a hole made through the stock. The harpoon is light behind, and heavy towarcts the point or before, like an arrow, that is made heary before with iron and light behind with feathers, so that fling it which way you will it doth always fall upon the point. "Through this hole cometh a piece of packthread, wherewith the end of the fore-rumner is fastened to the handle or stock of the harpoon, but this is soon torn off, and it serveth for nothing more after the harpoon sticks in the body of the whale; neither is the wooden handle of any further use, and so it doth soon come out from the iron.

When the whale is struck with the harpoon, all the other long-boats row out beforc, and take notice which way the line doth stand, and sometimes they pull at the rope or line. If it is stiff and heavy, the whale doth draw it still with his might; but if it hang loose, so that the long-boat is before and behind equally high out of the water, then the men pull in the rope again, and the rope-giver layeth it down in very good order, round, and one row above the other, that if the whale should draw on again, he may have it ready to give him without being entangled. Here is also this to be obscrved, that if the whale rums upon the level they must not give him too much rope, for if he should turn and wind himself much and often about, he might casily wind the rope about a rock or heavy stone and so fasten it to 
it, and so the harpoon would eome out and all the labour would be lost; which hath often happened, and we ourselves lost one that way. The other long-boats that are towed behind, wherein the men look all before them, and sit still and let the whale draw them along: if the whale doth row upon the ground, so that the long-boats or sloops do lye still, they draw their lines in again by degrees, and the ropemaster doth lay them down again in their proper plaees as they had been laid before. When they kill the whale with launees they also pull their lines in again, until they come near to the vhale, yet at some distance, that the others may have room to launee: but they must have great care, that all the lines of every sloop may not be eut off together, because some uhales sink, and others do swim even with the water when they are dead, which nobody ean tell beforehand whether they will do one or the other. The fat ones do not sink presently after they are fresh killed, but the lean ones sink immediately after they are dead, but after some few days they come up again and swim on the water: but it would be too long a while for a man to stay till he cometh up again, and the sea is never so quiet that one ean stay long in the same place, and where the sea is quiet and without waves, there the stream doth earry the ships and the ice along together, so that we should be forced to leave the whale unto others, that would find him dead some days after. 'Tis true this is the easicst way to eatch rhales, but it is very nasty and stinking work, for long and white maggots grow in their flesh; they are flat, like unto worms that breed in men's bellies, and they smell worse than anything I ever smelt in my life. The longer the whale lies dead in the watcr, the higher he doth swim above it; some swim a foot high above the water, others to their middle, and then they do burst easily, and give a very great report. 'They begin immediately to stink, and this enereases homrly, and their flesh boils and ferments like nnto becr or ale, and holes break in 
their bellies that their guts come out. If any man is enclined to sore eyes this vapour enflames them immediately, as if quicklime was flung into them. But when the live whales rise and swim again, some of them are astonished, others wild or stark mad: to those that are wild we come softly or gently from behind, as we do when we are going to trapan them; for when the wind is down, the weather calm, and air serene, so that the sea doth not foam or roar, the whales hear immediately the striking of the oars.

If many small-ice sheets lay near to one another, so that we cannot follow the whale with our sloops or long-boats, we fetch in our line with all might and strength, and if with one or more pulls we can fetch out the harpoon it is well, if not we chop off the rope or line. The whale is best and surest struck with a harpoon when he spouts water, as is already said above; for we do observe, when they lye still and very quiet, that they then listen, and are sometimes under and sometimes above water, so that their back doth not quite dry, and before we are aware of it he flings up his tail behind out of the sea, and so bids ns good buy. The whales may easily be caught when the air is very serene and clear and the sea quiet, and where there float neither great nor small ice-sheets, so that we may go in between them with our boats or sloops to follow them; for at the ice-fields the whales do commonly lye and rub themselves at them, perhaps by reason of the lice that bite them. Besides, against the iceshcets the sea beats, dashes, and foams, with small curling waves, so that the whales do not observe nor mind the striking of the oars, and so they are easily struck with the harpoon. It is very dangerous to kill a female, chiefly when she is big witl young, for they defend themselves very long, and are harder to be kill'd than a male one. Oftentimes the long-boats wait six or seven hours, nay, a whole day, for a whale before they see one.

Where great quantity of small ice is crowded together, 
there it is also very dangerous and hard to come to the whale, for he is so eunning that when he perceives where the ice is he retires thither immediately. The harpoonier stands at the head of the long-boat, and doth draw on the rope, to try whether it is heary or light; if it feels heavy, so that we are afraid it will pull the boat under water, then we give him more rope, if he runs streight ont before, he draweth the sloops after him. If he doth run underneath a great icefield, the harpoonier taketh a knife in his hand, which they call a chopping-knife, and if the ice-field be hollow, or spongy, or full of holes in the middle, so that the whale can fetch breath underneath it, and the rope is not long enough to follow him, and if the ice be several miles long, they draw the rope in as much as possibly they can until it be streight, and then he chops it off, loosing the piece of the rope whereon the harpoon is fastened, that sticketh in the body of the whale, yet not without great loss, for oftentimes they run away with the lines that belong to five and more sloops. It happens very often that they run to the ice with the long-boats, so that they dash against it as if they would break it into pieces, which also very often happens. But when the whale rises again they oftentimes fling one or two more harpoons into him, according as they find he is tired more or less: then he dives under water again. Some swim or run even all along. on the water, and they play with their tail and finns, so that we must have great care that we may not come too near them. When the whales fling their tails about after this manner, they wind the line about their tail, so that we need not to fear the harpoon tearing out, for then they are ty'd strong and firm enough with the rope. After they are wounded they spout with all their might and main, so that you may hear them as far off as you may a cannon; but when they are quite tired it cometh out only by drops, for he hath not strength enough to force the water np, and therefore it sounds as if you held an empty mug or bottle under water, 
and the water rums into it. And this sound is a certain sign of his feebleness and that he is going to expire. Some vthales blow blood to the very last after they have been wounded, and these dash the men in the long-boats most filthily, and dye the sloops as if they were painted with a red colour ; nay, the very sea is tinged red all along where they swim. Those whales that are mortally wounded, heat themselves that they reek while they are alive. When the whales blow up the water, they fling out with it some fattish substance that floats upon the sea, like sperm, and this fat the mallemuckes devour greedily, of which several thousands attend him, so that a whale often hath more attendants than a king hath servants.

Sometimes also the harpoons break out; then often longboats of other ships attend, and as soon as they see that the harpoou is come out, they fling their own into him, and the whale is theirs, although the first harpoon hath almost killed the whale; yet if he doth get loose the second party claims him, and the first must look for another. Sometimes at the same time two harpoons, belonging to two several ships, are struck into the whale; such ones are divided equally, and each one hath half; the other two, three, or more sloops, as many as there is of them, wait for the whale's coming up again, and when they see that he is tired they kill him outright with launces. In doing this is the greatest danger, for the first that do fling the harpoon into him are drawn along by the whale, and are at a good distance from him, but those that kill him with launces are as well upon his borly as at his sides, according as the whale turns and winds himself, and they receive many and severe blows. Here the steersman must take care to observe how the whale runs and turns himself about, that the harpoonier may reach him with his launces: all the other men in the sloops row diligently, sometimes forwards and sometimes backwards, which they call rowing on and striking, and when the whale lifts up him- 
self out of the water, he commonly doth strike about with his tail and finms, that the water dasheth up like dust. A longboat he values no more than dust, for he can bcat it all into shatters at a blow: but a great ship is too hard for him, and if he strikes against it with his tail, he feels it more than the ship, for he doth so paint the ship with his own blood that it maketh him very feeble. A good steersman is next unto the harpoonier most useful in the sloop; he stecrs with one oar, and doth look out before: the other four men turn their back to the head and look towards the stern, therefore doth the steersman and harpoonier always cry, "Row on," or "Strike," that is to say, row near to the whale, or else keep farther off. The launces have a wooden stick or handle above two fathoms long, or somewhat shorter than a pikestaff; the iron thereof is commonly a fathom long, and pointed before like unto a pike: it is made of steel or tough iron, that it may bend without breaking. For after you have made a deep hole in his body with your launces, you poke into it with them one way and the other way, as they do when they poke for eels; but if he doth get one or more out of your hands, you take another, for every sloop liath at least five, six, or seven, and yet sometimes he has them all out of three, four, or more boats sticking in his body.

\section{CHAP. IX.}

What they do with the Dead Whate.

AfTEr the whale is killed they cut off his tail; some keep the tail and finns, and hang them up at the outside of their ship, for that defends them from the ice when it presseth upon the ship; the tail hinders the boat and its course, be- 
cause it doth lyc across, and that is the reason why they cut it off. Before the tail they fasten a piece of a rope, and the other end at the stern of the last sloop. 'There is in all four or five sloops fastened to one another behind, and so they row one behind the other to the great ship. When they have brought the whale to the ship, they tye it with ropes fast to the ship ; that part where the tail is cut off they fasten to the forepart of the ship, and the head towards the stern, abont the middle, near the great shrouds of the mainmast on the larboard side of the ship. It is seldom that a whale doth reach farther than from the poop to the middle of the ship, except the vessels are very small.

By the larboard is to be understood that side of the ship that is at your right hand as you go from before towards the stern; but that side of the ship that is on your right hand as you go from the stern towards the forepart is called the starboard, because you go from the steer forward.

Whoever of the ships crew sees a dead whale, cries out "Fish mine," and therefore the merchants must pay him a ducat for his care. and vigilance. Many of them climb often up into the mast in hopes to have a ducat, but in vain.

When the dead whale is thus fastened to the ship, two sloops hold on the other side of the fish or whale, and in each of them doth stand a man or boy, that lias a long hook in his hands, wherewith he doth hold the boat to the ship; and the harpoonier stands before in the sloop, or upon the whale, with a leathern suit on, and sometimes they have boots on. Underneath the hook are some sharp nails fixed, that they may be able to stand firm, for the whale is very slippery, so that one may easily fall, as upon slippery ice. These two men that cut the fat off have their peculiar wages for it, viz., about four or fire rix dollars. First, they cut a large piece from behind the head, by the eyes, which they call the kinter-picce, that is as much as to say the windingpiece; for as they cut all the other fat in rows from the whale 
towards the end, so they cut this great kenter-piece larger and wider than all the rest. 'This piece, when it is cut round about from the whale, reaches from the water to the cradle (that is, the round circle that gocth round about the middle of the mast, and is made in the shape of a basket), from whence you may guess at the bigness of a whale. A strong and thick rope is fix'd to this kenter-piece, and the other end is fixed underneath the cradle, whereby the whale is as it was borne up out of the water that they may come at it, and by reason of the great weight of the whale the ship leans towards that side. One may juclge how tough the fat is, for in this piece an hole is made through which the rope is fastened, yet not deep into the fat, wherewith they turn the fish at pleasure. Then, as is before said, they cut another piece hard by this, that is also halled up to the ship; and then in the ship they cut it into less pieces, about a foot square. These two men have in their hands, as well as those that stand on the whale, long knives, wherewith they cut these square pieces. These knives, with their hafts, are about the length of a man; and the more the fat of the whale is loosened,-just as the hide is flea'd from an ox, the higher must they pull up the fat with their pulleys, that they may cut it the casier.

And when they have drawn up this fat, the men take it into them into the ship, and loosen the rope that it was fastened unto. 'The rope is fastened with a ring, whereinto they put a great iron hook, which is fastened to a strong tackle, and also sometimes, before in the ship, are fix'd two other tackle, wherewith all the fat is drawn up into the ship. In the ship stand two men, with hooks as long as a man, wherewith they hold the great piece of fat, which the two men cut into square pieces with their long knives. By them stands another that has a short hook with a ring in his hands, which he thrusts into the pieces of fat that are cut square, and puts it on the bench or dressing-board, where it is ent by others into less 
pieces. The two first men with their long knives, that eut the large pieces of fat, stand near the larboard of the ship, at that side where the whale is fix'd, and the other men that afterwards cut it into less pieces, stand on the other side called starboard. When it is a good time to catch whales, and they will not lose it, they tow sometimes several fish behind their ship and catch more; and they cut only the great pieces of fat of them, and fling them underneath into the ship. But when they have no more vessels to put their fat into, they sail into an harbour, or if it be calm weather and not windy, they stay in the sea, and fasten themselves to a shect of ice, and so they drive along with the stream. The other men cut the fat into small pieces on a table; on the further side of the tail is a nail fastened, whereunto they fasten a hook, which they put into the fat, that it may lye steddy when they cut it into small pieces: the fat is tough to eut, wherefore it must lye firm. That side whereon the skin is they lay undermost, and so cut the fat from it by picces. The knives wherewith they cut the fat into small pieces are less than the other, about three foot long with their hafts. 'They all cut from them that they may not be bedaubed with the fat, which might occasion a shrinking up and lameness of the sinews of their hands and arms. One of them cuts the soft and tough fat into small pieces with a long knife; this man they call the chopper, and he is mightily danbed, wherefore he doth hang about him all sorts of rags and clouts he can get. 'The fat of some whales is white, of others yellow, and of some red : the white fat is full of small sinews, and it doth not yield so much oyl as the yellow : the yellow fat that looks like butter is the best. The red and watery fat cometh from dead whales, for in the place where the fat runs out the blood settles in its room, and yields the worst and least oyl. Before the table is a gutter, made of two boards nailed together, whereinto the small or minced fat is flung; by it stands a boy, that shuffles the fat by degrees into 
a bag that is fixed to the end of the gutter, and is like unto a pudding-bag, so that it reaches down into the ship); out of this bag the fat runs down into a tub or wooden funnel, which they put upon empty vessels or cardels, as they call them, and the men that are below fill them up with it, and so it is kept until they try it up into train-oyl. When the fit is eut off from one side of the whale, before they turn him, they cut out the whale-bone in one entire piece, and this is so heary that all the ship's crew hath cnough to do to pull it up. They make use for that purpose of a peculiar sort of hooks, two whereof they fix on the sides and one on the middle of it, very well provided with strong tackle; and afterwards they cut out the whalebone of the other side of the fish, and draw it up also with pulleys into the ship, where it is cut into such pieces as they bring it hither in.

The whalebone doth only belong to the owners of the ship and the others that run their hazard, whether they catch few or many whales. 'Ihe rest, which take their pay by the month, receive their money when they come home whether they have caught many or none, and the loss or gain falls upon the merchants.

The hooks that they crane up the whalebone withal are made on purpose for it, like a beim of a pair of scales; on each end are two sharp points, which they knock in between the whalebone; in the middle of the beam is fastened a long handle with a ring, whereon the ropes are fastencd; on this handle there are fixed two other crooked hooks, like birds claws; in the ring where the ropes are fastened is another crooked hook, at the top fastened by a ring, such a one as we make use of here when we wind anything up by a crane; but in the middle between these two hooks is fastened another rope, which keeps the lowermost hook steddy; the two hindmost points are knock'd into the whalebone behind and the two forcmost short ones before, which hold the whalebone fast between them when it is wound or pulled up. 
The dead whales, when the fat is cut off of them, they let float, and are the food of birds of prey when they are hungry; but they had rather have dead whales that have still their fat left on them. The white bear is generally not far off, whether there be any fat left on them or no, and look like dogs that only feed on carrion; and at that time their white furr is turned into a yellow colour, and at the same time they shed their hair, and their skins are worth very little. Where a dead whale is near we see it by the birds, whereof are many, and also the white bears discover it, chiefly in the spring, when but a few whales are canght, for then they are greedy of their prey ; afterwards, when many whales float on the sea, they have their bellies full, and we do not find so many by a whale, because they are clispersed.

\section{CHAP. X.}

Of the Trying out of the Train-Oyl from the Fat.

Formerly the Dutch did try out their train-oyl in Spitzbergen at Smevenberg, and about the Cookery of Harlingen, where still, for a remembrance, all sorts of tools belonging thereto are to be scen, where of I have made mention before. 'The French-men try up their train-oyl in their ships, and by that means many ships are burnt at Spitzbergen: and this was the occasion of the burning of two ships in my time.

'Ihey try out their train-oyl at Spitzbergen that they may load the more fat in their ships; and they believe it to be very profitable, for they go their voyage upon part, that is to say, they receive more or less according to what they catch; but I do not account it wislom to fill up the room of the ship with wood where they might stow ressels. But our country- 
men, as I told you before, put the fat into the vessels, wherein it doth ferment just like beer; and I know no instance that ever any vessel did fly in pieces, although they are stop't up very close, and so it becometh for the greatest part trainoyl in them. Of the fresh fat of whales, when it is burnt out, you lose twenty in the hundred, more or less according as it is in goodness. At the place where they try up the fat into train-oyl, near Hamburg, they put the fat out of the ressels into a great wooden trough or tub, and out of this two men empty it into a great kettle that stands near it, that doth hold two cardels of fat, that makes one hundred and twenty, one hundred and thirty, and sometimes one hundred and forty gallons. Underneath this copper, that is made up with bricks, they put the fire; and so they boil it and try it up into train-oyl, as you try up other fat. 'This copper is very well secured, as the dyers coppers used to be : it is very broad and flat, just like a frying-pan made of copper. When the fat is well tryed or fryed out, they take it out of the pan with small kettles into a great sieve, that the liquid only may run through; the rest is thrown away. This sicve stands over a great tub, which is above half filled with cold water, that the hot train-oyl may be cooled, and that what is unclean and dirty of the blood and other soil may fall to the bottom, and only the clear train-oyl swim at the top of the water, like other oyl. In this great tub or trough is a small spout or tap, which doth run out over another as big as a tub, out of which the train-oyl runs into another tub when it is almost ready to run over; which is also filled with cold water to the middle, wherein it is more cooled and becomes clearer, and more refined than it was before. In this trough is another spout, through which the trayn-oyl runs into the warehouse into a vatt, whereout they fill it into cardels or vessels. Some vessels have but two tubs. A cardel or hogshead holds sixty-four gallons. A true trayn-oyl barrel doth hold thirty-two gallons. The greaves they try 
up the second time and make brown train-oyl out of it; others, that think it not worth their while, fling them away.

\section{CH A P IER XI.}

Of the Finn-Fish.1

Tin fim-fish is of the length of a whale, but in bulk the whale is three times as big. They know the fim-fish by the finns that are upon his back, near unto his tail, and also by his vehement blowing and spouting up of the water, which the whale doth not do. Mis knob on the head is split in length, that is at his blowing hole, through which he forces up the water higher than the whale, and with more fierceness, which is not so high as that of the whale, neither is the back bended or clented in so much. His lips are of a brownish colour, and like a twisted rope. On his upper lip the whalebone hangs as it doth on the whale; but whether he doth open and shut his mouth there are different opinions: some believe that he cannot open his month, yet this is not true; but he doth not always run open mouth'd, that the whalebone may not hang out of his mouth at the sides as it doth in whales, or else he can open his mouth if he pleases. Within his mouth, between the whalebone, he is all over hairy, like unto horse's hairs, which grow within to the whalebone that is new growing, and it is of a blew colour; the other whalebone is of a brown colour, and dark brownish with yellow stroaks, which are estecmed to be the oldest; the blew whalebone cometh from young whales and finn-fishes. He is not as black as relvet, as the whale is, but like a tench. The shape of the body is long and small: neither is he so

1 Physalus untiquorem, Gray ; the Razor-back of the whalers. 
fat as a whale, wherefoic we do not much care to catch him, for he doth not pay us for our labour. It is much more dangerous to kill him than to kill a whale, because he moves quicker and beats about him with his tail, and from him with his finns, so that we dare not come near unto him with our sloops or long-boats, for the launces kill him soonest. I was informed that once some, before they were aware of it, did fling, by a mistake, their harpoon into a finn-fish, whereupon he drew both boat and men, all on a sudden, underneath a large icc-sheet before they were aware of it, and not one of them escaped. His tail lies flat, like unto that of the whale. When the finn-fishes appear, we see no more whales. 'The train-oyl of the whale is used by several, viz., by the frize-makers, curriers, cloth-worliers, and soap-boilers, but the greatest use that is made of it is to burn it in lamps instead of other oyl.

The Greenland ships carry thirty or more men, and sometimes more, chicfly the great ships, that have six sloops belonging to them : such ships hold from eight hundred to one thousand cardels of fat; the less ships have commonly fewer cardels or vessels, from four hundred to seven hundred, and have commonly five sloops or boats belonging to them. There also go galliots to Spitzbergen to catcl whales; they have three or four sloops belonging to them. Some put the sloops upon the deck of the ships, others hang them overboard, as they do at Spitzbergen when they are amongst the ice, that as soon as they call "Fall, fall," they may immediately let down their sloops into the water. Then there remains on board in the ships the stcersman, the barber, the chyrurgion, the cooper, and a boy, to look after the ship; the skipper or commander himself goeth out with the rest of the men, for they are all obliged to go a whale-catching.

In each ship there are sixty launces, six sea-horse launces, forty harpoons, ten long harpoons, wherewith they strike the whales under water, six small sea-horse harpoons, thirty lines 
or ropes, and cach of them is about eighty or ninety fathoms long. When they go a hunting they take along with them into each sloop, two and sometimes three harpoons, six launces, two or three sea-horse launces, three lines, and five or six men, according to the bigness of the sloops; therein is the harpoonier, line-keeper or giver, and the steersman: they all row equally until they come near to the whale, except the steersman, for lie guides the boat with his rudder; they also have in each sloop a chopping-knife, to cut off the rope when they camnot follow the whale, and a hammer and other instruments, as hatchets, drags, and several sorts of knives, wherewithal they cut the whales. Meat and drink is also given them according to the usual custom; he that will have better must take it along with him.

Lazy fellows are in this voyage troubled with the scurvy, but those that fear neither air nor wind and bestir themselves escape pretty well; else scurvy is the common distemper in this voyage, besides fevers, imposthumes and other accidental distempers, and therefore the chyrurgion must take care to provide himself.

\section{CHAP. XII.}

Of Rotz-fishes and Sea-qualms. ${ }^{1}$

Rotz-FIsIr (or stime-fishes) I call these, that in themsclves are nothing else but slime, and they are transparent. I have observed several kinds of these, some whereof have parts like fimms, as that same which I call the sea May-flie. Others are like unto the flat snails, only instead of finns they have stalks like unto feathers. Besides these, I have seen four other sorts that are quite differing in shape from the others, 
and are called sea-qualms by the seamen, as if they were a thick seum of the sea coagulated together. 'They are also called after the Latin name sea nettles, because they cause a burning pain like unto nettles. I have formerly had some thoughts that the rotz or slime-fishes might be a seed flung out and so putrefied, and that they did cause this burning pain by reason of their putrefaction; and so I did think they received their shape or form according to the several kind of fishes from whence they eame, and that some did take after thornbacks, others after whales, and the like; but this doth not seem to be agrecable to reason, for I have considered it better since, and find life to be a far more noble thing than that it should proceed from putrefied seed cast a way.

They clcanse the sea mightily, for all the filth and uncleanness sticks to them just as a burr doth unto cloth.

\section{Of the Sea Nay-flye. ${ }^{1}$}

These small fish are very like unto the sea-nettles, because of their transparent body, and they also dissolve like the same, if you hold them in your hand. They have two finns underneath about the neck, which are likest unto those of the whale. 'They are in their shape like unto our white rowls, broad and thick in the middle, and thin and pointed at each end. As for the rest of the body, it is very like unto our May-fye, save only that the tail or body is all along thicker, and only begins to be pointed towards the end. The head is broad and round, split in the middle; it hath small horns about the breadth of a straw; on his head before it hath two rows of six little red knobs, three of them in cach row; whether they be cyes or no I cannot exactly tell. Its mouth is divided or split. From his mouth down into his belly are its guts, which one may easily see

1 Clio boicalis; the Clio limacina of Phipus. Voyage, App., p.95. 
because of its transparency. It is of a yellow and black colour, but the colour of the whole fish is like unto the white of an egg; he moves in the water just like a sea nettle. I have drawn him liere in his proper bigness. I am of opinion, that the birds feed upon them, because the lumbs, pigeon-divers, and parret-dicers are plentifully seen in those places where these fish or sea insects are seen. The same that I have delineated here I found in the South Bay in Spitzbergen, on the 20 th of June.

\section{Of the Snail Slime-fish. ${ }^{1}$}

These are also quite transparent, like unto the seu nettles, but they are flat and wound about like a snail; and so we find upon the land the shells of such flat snails. It is very remarkable, that out of the utmost part of him come two stalks, like unto the beam of a pair of scales, hairy or rough on each side, like unto a feather. With these stalks he moves himself up and down like the sea nettle. They are of a brown colour. They swim in great numbers in the sea, as numerous as the dust in the sun. It is believed that the whales feed upon them, but I cannot believe that they can be so nourishing a foord for the whales as to make them so fat; I rather believe that the lumbs, pigeon-dicers, and purret-divers feed upon them. We saw many of them in the South-harbour at Spitzbergen, on the 20th day of June. Amongst the ice I saw none. The seamen take these small fish for spiders, and I should also have taken them to be such, if I had not had them in my hand and looked more curiously upon them, and found that they had no affinity with the spiders.

3. Of the Hat Slime-fish.

Its upper part is like the fungusse or toadstools, for it is

1 Limacina arctica; the Clio helicina of Phipps. App. p. 195. 
as it were a round and thick stalk that goes just into the middle of the head. It hath a blue button or knob, that is as thick again as the stalk, and this upper part may also be compared unto such a straw hat as our women wear. From the stalk downwards it doth grow thick again and round, yet it is a great deal less than the button. I have seen them force themselves up from below, and then from the top down again, just as a stick that is foreed down underneath the water reboundeth up again. I got them in the North-Sect, between Holly-Land and the Elbe, where the sca-water mingles with that of the Elbe. I have also scen them at Iruck's-haven in the Elbe; and I am also informed that sometimes they come as far down as to Freyburg. By reason of its shape, it may be called the hat slime-fish, or stalli slime-fish.

4. Of the Roselike-shaped Slime-fish.

This Slime-fish is as round as a circle, yet in his circumference between his double strokes a little indented, the rays spring out single from the middle of the body, and there are sixteen of them in number, but they divide themselves into two branches, where they rm somewhat closer together, and are split in two. 'The body thereof is white and transparent, as is mentioned before; he draws it together, and opens it again as he pleaseth; but the rays or spokes are brownish red. On the end of these spokes, towards the outer circumferenee, are several spots, thirty-two in number. In the midlle of this plate is another small circle, and from the circumference of that the before-named spokes begin. It is hollow within, which eavity may perhaps be his belly, wherein I found two or three of the small shrimps. ${ }^{1}$ Round about did hang down seven brown small threads, like spun silk, or like unto the threads that flye in the air about

1 Probably Metoecus meduscrum or a Phronimu. 
autumn; he cannot move these; I believe he weighed about half a pound; he was about half a span broad; the threads were about a span long. This sort we got about Hitland. One might very well call him the plate or rose-like slime-fish, by reason of his figure and shape. I have heard some relate that the macurcls do suck their colour out of these two, but I cannot affirm it, but leave it undecided until I can assert it by my own experience. These three first sea-qualms are numerous in the North Sea as atomes in the air, but about Spitzbergen we do not find many of them. I have seen them swim at top only in calm weather, but in stormy weather they sink to the bottom.

\section{Of the Slime-Fish like a Cap.'}

At Spitzborgon, near the Muscle-Harbour, on the 8th of July, when the weather was calm, I saw two sorts of slimefish, whereof one had six, the other eight corners; that with six corners had also six purple streaks, with blew brims. Between these streaks the body is divided like unto a pumpkin, into six ribs. From the middle of his body hang down two threads, that are red like vermillion, and rough, of small hairs; they are shaped like unto the letter $V$. I did not see him move them when he swam. Within his body he hath other broader streaks, of a purple colour, and on the edges or brims of a lightish blew one; they represent themselves like unto a great $W$. The whole body is as white as milk, and not so transparent as the body of that that cometh next.

It is shaped just like a cap with corners, wherefore one might call it the cap-like fish.

It weighed about two ounces. I did not perceive, when I had him in my hand, that he did burn me; but it dissolved like snot or slime.

1 Beroe pilcus. 
6. Of the Slime-Fish like-a Fountain.'

The sixth and last is a very notable fish; it hath a hole at the top like unto the quill of a goose (that may perhaps be his mouth), which goes into a cavity like a funnel, wherefore we might call him a funnel-fish. From this loole come down four strokes, two and two exactly opposite to one another: two of them are cut transversedly, and two are not cut. 'Those that are not cut are about half the breadth of a straw, and the others, that are like unto the backbone of a snake, are as broad as a straw; both of them come down beyond the middle of the whole body. From the middle of the funnel come down four others, like unto the backbones of a snake, and they come down lower than the others; so that all of them make eight in number: they chang'd their colour, as we look'd upon them, into blew, yellow, and red, with such delicate colonr's as a rainbow. 'They look'd in my eyes to be like mnto a fountain, with eight streams or spouts, wherefore we might call it a fountain-fish with eight streams.

Within him came down from the end of the funnel something like a cloud, that divided itself into rows, which I take to be his intrails. Where the before-mention'd outward streaks end themselves, the body is first bent in somewhat, then it turns round, and then it hath many small streaks. The whole body is as white as milk. I believe it weigh'd about four ounces. I did not perceive that he did burn ones skin, but he did, like him I mentioned before, dissolve like slime. Since, I have secn other sorts of these sea-nettles in the Spanish Sea, that weigh'd several pounds, and they were

1 Nedusa Infundibulum. Gmel. Syst. Nat. 3152-3. Cuvier thinks it another species, and to belong to another division (Règne animal). 
of a blew, purple, yellowish, and white colour, that burn more violently than those of the North Sea; they suck themselves so close to the skin that they raise blister, and cause sometimes St. Anthony's fire. 
A P PENDIX. 



\title{
A P P E N D I X.
}

\section{LIST OF 'THE ANIMALS OF SPITZZBERGEN.}

\author{
MAMMALIA.
}

\section{White Bear. Page so.}

Tinalassarctos maritimus-The Polar Bear.

Ox Phipps" voyage many were killed, "and the seamen ate of their flesh, though exceeding coarse". On Parry's expedition, the flesh of the bear proved a timely and valuable addition to their stock of provisions, and served materially to restore the strength of the party during their journey orer the ice towards the North Pole. The commander in his narrative (p. 114) relates, that "a fat she-bear crossed over a lane of water to visit us, and approaching the boats within twenty yards was killed by Lieut. Ross. The scene which followed was langhable, even to us who participated in it. Before the animal had done biting the snow, one of the men was alongside of him with an open knife, and being asked what he was about to do, replied that he was going to cut out his heart and liver to put into the pot, which happened to be then boiling for our supper. In short, before the bear had been dead an hour, all hands of us were employed, to our great satisfaction, in cliscussing the merits, not only of the said heart and liver, but a pound per man of the flesh; be- 
sides which some or other of the men were constantly frying steaks during the whole day, over a large fire made of the blubber. The consequence of all this, and other similar indulgences, necessarily was, that some of them complained for several days after of the pains usually arising from indigestion; though they all, amusingly enough, attributed this effect to the quality, and not the quantity of meat they had eaten. 'The fact however is, that the flesh of the bear is just as wholesome, though not quite as palatable as any other; and had they eaten moderately of it, as the officers did, they would have suffered no inconvenience whatever. However, notwithstanding these excesses at first, we were really thankful for this additional supply of meat; for we had observed for some time past that the men were evidently not so strong as before, and would be the better for more sustenance."

Capt. Beechey gives an instance of the cunning displayed by this arctic tyrant, which he witnessed on the shores of Spitzbergen in 1818. "One sunshiny day a walrus, of nine or ten feet length, rose in a pool of water not very far from us, and after looking around drew his greasy carcass upon the ice, where he rolled about for a time, and at length laid himself down to sleep. A bear, which had probably been observing his movements, crawled carefully upon the ice on the opposite side of the pool, and began to roll about also, but apparently more with design than amusement, as he progressively lessened the distance that intervened between him and his prey. 'The walrus, suspicious of his advances, drew himself up, preparatory to a precipitate retreat into the water, in ease of a nearer acquaintance with his playful but treacherous visitor; on which the bear was instantly motionless, as if in the act of sleep; but after a time began to lick lis paws and clean himself, and occasionally to encroach a little more upon his intended prey. But even this artifice did not succeed; the wary walrus was far too cumning to allow himself to be entrapped, and suddenly plunged into 
the pool; which the bear no sooner observed than he threw off all disguise, rushed towards the spot, and followed him in an instant into the water, where $I$ fear he was as much disappointed in his meal as we werc of the pleasure of witnessing a rery interesting encounter." - Voyage of Dorothea and Trent, p. SQ ; see also p. 111 for other particulars of the habits of the bear.

Fox. Page 80.

Vulpes Ligopus-Arctic Fox.

Not very abundant apparently in Spitzbergen. On Phipps' expedition it was met with, but not very frequently, on the mainland and the adjacent islands. The commander records that "it smells very little", and that his party ate of the flesh of one, and found it good meat. On Parry's expedition sereral were seen near Hecla Cove, and one was shot on the western shore of Waygatz Straight.

Sea Dogs. Page 83.

Callocepinaus feetidus, Phoca foetida Mïller-the Rough or Ringed Seal.

Sir J. C. Ross mentions, that on Parry's expedition two young animals of this species were shot during the journey over the ice, and were found to be excellent food, and that some werc seen as far north as lat. $82^{\circ} \frac{3}{4}$. "The meat of these young animals is tender and free from oiliness, but it certainly has a smell and a look which would not have been agrecable to any but very hungry people like ourselves. We also considered it a great prize on account of its blubber, which gave us fuel sufficient for cooking six hot messes for our whole party, though the animal only weighed thirty pounds in the whole. These animals.... are, when very small, best procured by shooting them in the head with small shot; but if quite killed at once, they are apt to sink immediately and be lost."--Parry, Narrative, p. 91. 
Callucepiandus vitulines-Common Seal.

Scems to be met with on the coast of Spitzbergen.

Pagophilus Grentandicus-Harp Seal.

'This species, on Parry's expedition, was oceasionally seen on the loose ice of the pack to the northward and westward of Spitzbergen, and also at the Seven Islands of Phipps. For an account of the seal fishery in the seas around Spitzbergen and Jan Mayen Island, see Scoresby's Arctic Regions, i, 512-517.

\section{Cystophora cristatA--Hooded Seal.}

This seems to be a common species near Spitzbergen. Scoresby says that it often returns the attacks of its enemies, and being defended by its hood from the stuming effect of a blow on the nose, sometimes inflicts severe wounds on the person attacking it. (Arctic Regions, i, 511.) For an excellent account of the whole family of the seals, sec Dr. Gray's Catalogue of Mammalia in the British Museum, part ii (1850); fig. 13, p. 36, of that work, represents the skull of this species.

Sea Horse or Morse. Page 86 .

'Tichecus Rosmanes-Walrus or Morse.

Very numerous on the western eoast of Spitzbergen, and the Low Island of Phipps. On Parry's expedition none were seen to the northward of Walden Island. It is a gregarious animal, not generally inclined to attack, but dangerous if attacked, as the wholc herd resents any injury received by an individual. These herds consist occasionally of upwards of a hundred animals each. When a herd of these animals is asleep on the ice, they appear to take the precaution of having a sentinel to warn them of any danger to which they may be liable. Admiral Becchey has given, with his usual graphic powers, a good history of the habits of this species (Voyage of Dorothea and Trent, pp. \$9-(97), 
and of the formidable nature of its attack. He gives an account of the affectionate conduct of the wallus to its roung (p. so). "In the rast sheet of ice which surrounded the ships, there were occasionally many pools; and, when the weather was clear and warm, animals of varions kinds would frequently rise and sport about in them, or crawl from thence upon the ice to bask in the warmth of the sun. A walrus rose in one of these pools close to the ship, and finding cverything quiet, dived down and brought up its young, which it held to its breast by pressing it with its flipper. In this manner it moved about the pool, keeping in an erect posture, and always directing the face of the young toward the vessel. On the slightest movement on board, the mother released her flipper and pushed the young one under water; but, when everything was again quiet, brought it up as before, and for a length of time continued to play about in the pool, to the great amusement of the seamen, who gave her credit for abilities in tuition, which, though possessed of considerable sagacity, she hardly merited."

Scoresby, in the Aretic Regions, i, pp. 502-508, treats of the walrus as inhabiting the seas around Spitzbergen. A small specimen was brought alive to this country by a whaling captain in the antumn of 185.3 ; it lived but a short time. Dr. Gray secured the specimen for the British Museum.

Mromes Hudsoride-Illudson's Bay Lemming.

On Parry's expedition the skeleton of one of these animals was found in a floe of ice to the northward of Spitzbergen, in north latitude $81^{\circ} \frac{3}{4}$, at about sixty miles from the nearest known land. 'The peculiar formation of the fore-claws, which were quite perfect, pointed ont the species.

Hart or Deer. Page 79.

Ravgifer Tarandus-the Reindeer.

Found, both on Phipps' and Parry's expeditions, abundantly. Sir James Ross, in the appenclix to the narrative of 
the latter, says, that it was very numerous along the northern shore of Spitzbergen and near the Low Island of Phipps. Seventy were killed near 'Treurenberg Bay on this expedition (p. 191). They were not in good condition till the middle of August (p. 134). On Captain Buchan's expedition, Admiral Beechey records that the islands about Fair Haven are covered with lichens and other rich pasturage for reindcer, which are so abundant, "upon Vogel Sang in particular, that that island supplied us with forty carcasses. They wore at this time (the end of June) in such high condition, that the fat upon the loins of some measured from four to six inches, and a carcass, rcady for being dressed, weighed two hundred and eighty-five pounds. In August, however, they were so lean, that it was rare to meet with any fat upon them. From the wary disposition and the very keen scent of these animals, we found it extremely difficult to get within gunshot of them, especially from to windward; and were obliged either to separate into two or three parties, and to harass them until they took to the water, where they were easily overtaken by the boats, or to secrete ourselves behind large stones contiguous to one of their walks, and there wait until they approached. They were at this time in pairs, and when one was shot the other would hang over it, and occasionally lick it, apparently bemoaning its fate; and if not immediately killed, would stand three or four shots rather than desert its fullen companion.... Their sympathy must indeed have been very strong to have induced them to remain so long by their wounded; for if at other times our shots missed, the panic occasioned by the discharge of the guns was so great that they fled in all directions, and there was no chance of getting near them again. When pressed, they readily took to the water to swim to islands that were three or four miles distant." - Voyage of Dorothea and Trent, pp. $98-100$. 
The Whale. Page 104.

Batexa Mrsticetes-the Right Whale or Common Whale.

For much valuable information on its history, see Scorcsby's Arctic Regions, vol. i, pp. 449-478; and for an account of the modern mode of taking it as conducted at Spitzbergen, see vol. ii, pp. 157-351. In Dr. Gray's Catalogue of Cetacea in the British. Huseum, pp. 5-14, much valuable information is also given.

Balexoptera rostrata-the Pike Whale.

Scoresby (Arctic Regions, i, 486) mentions one of this small species haring been killed near Spitzbergen in 1813. He describes the whalebone of this spccimen as being thin, fibrous, of a yellowish white, and semi-transparent, almost like lantern-horns. It is curved like a scimitar, and fringed with white hair on the convex edge and point. Its length is nine inches, and its greatest breadth two inches and a quarter.

The Finn-Fish. Page 132.

Pmysates axtiquondr-the Razor Back.

Scoresby says this is "the longest animal of the whale tribe, and probably the most powerful and bulky of created beings". From its speed and activity it is difficult and dangerous to attack it, and from the smallness of its whalebone and the small quantity of inferior oil it affords, it is seldom pursued by the whaler. It is found not uncommonly in the Spitzbergen Seas.

Butskopf or Place's Head. Page 100.

Hrperoodox Butzkopf - the Bottle Head.

Apparently found in the seas of Spitzbergen.

The Unicorn. Page 101.

Moxodor Mloxoceros-the Narwbal.

The long prominent tusk is considered a hoin by the whales, and hence its name of "the unicom". Sce Scoresby, 
vol. i, pp. 486.495. On Parry's cxpedition several of these animals were seen amongst loose ice in north latitucle $81^{\circ} 40^{\prime}$, on the return of the party from the attempt to reach the North Pole over the ice. "They are seldom to be seen far within the edge of a 'pack', and their appearance was considered by the Greenland sailors as inclicative of our approach to open water, which proved to be the case much sooner than was expected."-J. C. Ross, App., p. 192.

The White Fish. Page 101.

\section{Beldga Catodor-the Northern Beluga.}

This is called "white whale" by the whalers. On Parry's expedition this species was frequently seen pursuing a small fish (the Mcrlangus polaris) along the shores of Hecla Cove, and in the shallow water at the head of 'Tremrenberg Bay.

Dolphin. P. 99.

Delphinus - Species.

There are many species of this genus and the allied genera, descriptions of which are given by Dr. Gray in the Zoolog!! of the Erebus and Terror, and in the Catalogue of Mammatia in the British Museum, part i, Cetacea.

\section{$B I R D S$.}

Snow Bird. Page 58.

Plectropinanes rivalis-the Snow Bunting.

On Phipps' expedition met with on Spitzbergen and on the ice adjacent to it in large flocks (p. 1SS).

Fringilia Linaria-the Lesser Redpole,

'Ihis, or perhaps F. borcalis, an allied species, was met with by 1)r. Scoresby on his approach to Spitzbergen. The birds alighted on different parts of the ship, and were so wearied, 
apparently with being on the wing, though the ship was not above ten miles from the shore, that they allowed themselves to be taken alive. (Aretic liegions, i, p. 5.3i.)

\section{Lagopes albes-the Ptarmigan.}

On Parry's expedition several were shot on the shores of 'Treurenberg Bay. It was also met with on the late French expedition ; it is figured in the Voyage en Seandinacie, etc., as the "Lagopus alpina var. hyperborea".

\section{Charadrius Hiaticula-the Ringed Plover.}

A single specimen shot in Hecla Core on Parry's cxpedition (p. 193).

\section{Trixgoïdes hypleuces-Common Sandpiper.}

Scoresby mentions it as seen in considerable flocks on the beach of Spitzbergen (Arctic Regions, i, 537).

\section{Snite. Page 57.}

Tringa maritma-the Purple Sandpiper.

On Parry's expedition found abundantly on the shores of Hecla Cove.

Beraicla Brexta-the Brent goose.

On Parry's expedition this species was seen in large flocks about Walden and Little Table Islands; a nest with two eggs was brought on board from Ross Islet, in latitude $80^{\circ} 48^{\prime} \mathrm{N}$., on the $16 \mathrm{th}$ of June. It was not seen to the northward of that place. (App., p. 196.)

Mountain Duck. Page 72.

Somateria yoluissima - Eider-Duck.

Scoresby says that the variety found at Spitzbergen is not so large as generally described, and that in size it very little exceeds the domesticated duck (Aretic Regions, i, 527). On Parry's expedition this species was only occasionally met with along the coast and on the islands to the northward. 
A few were shot at Hecla Cove (App., p. 197). Scoresby mentions that it is met with solitary, or in pairs near the ice at very great distances from land, and that, when met with in great numbers, the prescnce of these birds is an intimation of the proximity of land.

Somateria Spectablurs-King Eider-Duck.

On an islet in Fair Haven this species was very abundant in the summer of 1818. Captain (now Admiral) Becchey gives the following very interesting account of its habits as observed on this occasion. They were so numerous that it was scarcely possible to walk without stepping on their nests. "Could we have divested ourselves of all consideration for the young birds, we might have filled several sacks with that valuable commodity, eider-down, of which their nests were composed. It was the period of incubation; and we had many opportunities of witnessing the determined manner in which they defencled their nests, frequently remaining upon them until they were knocked over with sticks. Even the burgermeister', strontjagger, sea-swallows, and other birds, which were always hovering about and watehing for opportunities of devouring the eggs or the young birds, dared not molest the ducks whilst upon their nests, and could only secure their prey when foxes or some of the larger animals drove them into the sea. A practice, common to these birds, which I have not seen mentioned in their history, marks the provision which nature has made against some of the casualties to which their species are liable, and from which the young might be destroyed in their embryo state by the parents bcing kept away from their nests in so cold a climatc. When immediate danger compelled them to seek their own safety in flight, they hastily drew the down of the nest over the eggrs, and glued it there with a yellow fluid, which they deposited as they arose. This precaution not only kept in the warmth of the eggs, by interposing between 
them and the air a thick covering, which the cold would require some time to penetrate, but it was otherwise useful from its being of so very offensive a nature that the foxes would not touch the eggs that were tainted with it. If it happened that they were suddenly surprised, and compelled to take wing without making this provision for the safety of their young, they flew to a short distance only, and unless the danger was very imminent, would return almost immediately and cover up their nests, after which they took flight with apparently less solicitude. In Norway, these birds make their nests and lie amongst the juniper bushes; but here they build them amongst the rocks and loose stones upon the small islets off the coast. The down is of that tenacious character that it adheres to every rough substance it touches, and thus effectually prevents the nests being overturned or blown away by strong winds. The quantity of down required for one of these nests deprives the parent of a great portion of the down upon its breast, which is in consequence left nearly bare for a considerable time; and it is quite pitiable to observe the condition of those which have, probably, been obliged to make a second nest. The males may also be seen occasionally with their breasts denuded of down, from their having contributed to the formation of the nest. They are the constant attendants upon the ducks whilst they are sitting, and frequently procure food for them; they also assist in the defence of the young, and may sometimes be seen keeping the eggs warm whilst the ducks have gone to a distance to procure food. Here, however, their attentions appear to end for the season, for toward the close of the summer the drakes assemble and take thcir selfish departure, leaving the ducks to find their own way, and to help their young along in the best manner they can. In due time, however, they also take their departure, and immense flocks of adults and young may be met a hundred miles or morc from land, slowly migrating to the southward, some of the 
young birds being quite weak upon the wing."-Voyage of H. M. SS. Dorothea and Trent, pp. 100-103.

Conymbis glacialis-the Great Northern Diver.

On Phipps' expedition found on the coast of Spitzbergen (p. 187).

Conymbus Septentrionalis-the Red-Throated Diver.

Spitzbergen (Parry's Expedition, p. 197).

\section{AlCA TORdA-Razor-Bill.}

Spitzbergen. On Parry's expedition this species and the puffin were found in considerable numbers, breeding in the high acclivities of Walden and Little Table Islands. They were not met with to the northward of these points.

\section{Diving Parret. Page 71.}

Fratercula arctica - the Puffin.

Abundant in Spitzbergen.

The Lumb. Page 64.

Uria Troile-the Common Guillemot.

Uria Brunnicini - Brunnich's Guillemot.

Called "looms" by the sailors. Scoresby says that the guillemots cannot rise on the wing in any direction excepting to windward. If they attempt to fly to leeward, they have to run for a considerable distance along the surface of the water, and at length they fall into it. They swim and dive well, and evade shot when fired at, although not so certainly as the next species. Their fect compensate for the shortness of the tail in flying, and are used as a helm. (Arctic Regions, i, 533.)

The Pigeon. Page 63.

UriA GRYLLE-the Black Guillemot.

This is called "dovckie" or " doveca" by the whalers. It is remarkably watchful and quick in diving, and when diving uses its wings under water. Its flesh, which is very 
dark-coloured, tastes, according to Dr. Scoresby, a little like the liver of some animals, and is not unplcasant eating. (1. c. 532.)

\section{Rotge. Page 68.}

Arctica ALLE-the Little Auk or Common Rotche.

This species is very abundant in Spitzbergen, and was seen and heard as far north as Sir Edward Parry and his party travelled. Admiral Bechey, in his narrative, speaks of a high pyramidal mountain of granite in Magdalena Bay, " termed Rotge Hill, from the myriads of small birds of that name which frequent its base, and which appear to prefer its environs to every other part of the harbour. 'They are so numerous, that we have frequently seen an uninterrupted line of them extending full half way over the bay, or to a distance of more than three miles, and so close together that thirty have fallen at one shot. This living column, on an average, might have been about six yards broad and as many deep ; so that, allowing sixteen birds to a cubic yard, there must have been nearly four millions of birds on the wing at one time... When it is told that the little rotges rise in such numbers as completely to darken the air, and that their chorus is distinctly auclible at a distance of four miles, the cstimate will not be thought to bear any deduction." - Voyage of Dorothea and Trent, pp. 46, 47. Dr. Scoresby says they feed on shrimps, and are found in greatest numbers in the turbid dark-green coloured sea. On the approach of thick weather, he remarks, they are particularly noisy (l. c. p. 528).

\section{Mallemucke. Page 75.}

Procelitaria glacialis-the Fulmar Petrel.

Abundant around Spitzbergen. Sir J. C. Ross (App. to Parry's Nar., p. 196) says it was one of the few birds which were found at the northernmost latitnde attained by the expedition. 'This bird is the constant companion of the whale- 
fisher, and as soon as a whale is about to be flensed, " they rush in from all quarters and frequently accumulate to many thousands in number.... It is highly amusing to observe the voracity with which they seize the pieces of fat that fall in their way; the size and quantity of the pieces they take at a meal; the curious chuckling noise which, in their anxiety for dispatch, they always make; and the jealousy with which they view, and the boldness with which they attack, any of their species that are engaged in devouring the finest morsels."-Scoresby, 1.c., p. 530.

Stercorarius pomarines-Pomarine Skua.

On Parry's expedition to Spitzbergen, one flew past the boats in lat. $82^{\circ}$ N. (J. C. Ross, l. c., p. 106.)

Strunt-jager. Page 69.

Stencorarios Parasiticus-Arctic Skua.

Spitzbergen. (Abundant at Walden Island, etc.) It not only feeds at the expense of other birds, but preys also on their eggs and young. The "Larus crepidatus-Black-toed Gull or Boatswain," mentioned by Scorcsby (i, 534), is the young of this species.

\section{Rirodostemina Rossiz-Cumeate tailed Gull.}

"Several were seen during our travels over the ice, and as far north as the expedition went. Lientenant Foster also found them in Waygatz Strait, where it is probable that they breed."-J. C. Ross, l. c., p. 195.

Burgermeister. Page 67.

Larus graucus-Glaucous Gull or Burgomaster.

"It may with propricty be called the chicf magistrate of the feathered tribe in the Spitzbergen regions, as mone of its class dares dispute its authority, when, with unhesitating superiority, it descends on its prey, though in the possession of another." (Scoresly, l. c., i, 535.) When without other 
food, Scoresby says that it falls upon the smaller species of birds and eats them.

Xema Sabrint-Forked-tailed Gull or Sabine's Gull.

"Several individuals were scen by Lieutenant Foster in Wragatz Strait."-J. C. Ross, in Parry's Narrative, p. 195.

Kutge-gehef. Page 65 .

Rissa TrIDACTYLA-the Kittiwake Gull.

On Parry's expedition this gull was observed feeding on the Merlangus polaris and Alpheus polaris, as far as the experlition went to the northward; it was very abundant in the autumn along the shores of Spitzbergen, on Ross Islet, and on Low Island. (J. C. Ross, l.c., p. 195.) It feeds eagerly on the blubber of the whale, but generally seizes its morsel on the wing (Scoresby, i, 534).

Rathsher. Page 62.

Pagophila eburnea-Ivory Gull or Snow Bird.

First described scientifically in Phipps (p. 187). It was found as far north as Parry's expedition travelled, and very abundantly in the neighbourhood of Hecla Cove (J. C. Ross in Parry, p. 194). Although "so delicate in its appearance, it is almost as ravenous as the Fuimar, and as little nice in its food. It is, however, more cautions. It is a constant attendant on the flensing operations of the fishers, where it gencrally seizes its portion on the wing. It rarely alights in the water, but often sits on the ice, preferring the most elevated situations. Its voice is a loud and disagrecable scream."-Scoresby, i, 535.

\section{Kirmew. Page 73,}

Sterna macroura or arctica-the Aretic Tern.

On Parry's expedition, this species was found breeding in great numbers on a small islet in the centre of a lagoon near the south end of the Low Island of Phipps (J. C. Ross, 1. c., p. 194). 


$$
\text { FIS II ES. }
$$

Scomber scomiros-Common Mackarel.

Mentioned by Martens (p. 97).

\section{Mulius barbatus?-Red Surmullet?}

Scoresby (Arctic Regions, i, 541) refers to this as having been taken by a seaman out of the mouth of a seal near Spitzbergen. The body was wholly red; the length about twelve inches. "It was boiled," he adds, "for our officers, and proved an excellent dish."

Stomias Ferox.

Spitzbergen. (Krroyer, Nat. Tidsk, 1847, 253; Voy. en Scand., t. 16 b, f. 1.)

Cyclopterus spinosus-Spiny Lump-Sucker.

Spitzbergen. (Kroyer, Nat. Tidsk, 1847, 262.)

Liparis commexis-Unctuous Sucker.

(Liparis Fabricii, Kroyer, Voy. en Scand., t. viii, f. 2.)

Seven Island Bay (Phipps); westward of Low Island (J. C. Ross); Bell Sound (Kroyer, Nat. Tidsk, 1847, 2i4).

Merlangus rolaris-Arctic Coal-fish.

Abundant in small bays, where streams of fresh water rum into the sea (J. C. Ross).

Ophidium Parrit, or a closely allied Specics.

Amongst sea-weed on the shore of $\mathrm{W}$ alden Island (J. C. Ross, 1. c., 199).

Dragor EIsh-Martens. lage 99.

Spitzbergen.

$$
\text { IIay. Page } 103
$$

Dalatias microcepiralus-Northern Shark.

(Squalus borealis - Greenland Shark. Scoresby.)

Spitzbergen: "One of the foes of the whale. It bites it 
and annoys it while living, and feeds on it when dead. It scoops hemispherical picces out of its body, nearly as big as a person's head; and continues scooping and gorging lump after lump, until the whole cavity of its belly is filled. It is so insensible of pain, that though it has been run through the body with a knife and escaped, yet, after a while, I have seen it return to banquet again on the whale, at the very spot where it received its wounds" (Scoresby, l. c., i, 539). 'The same author has never heard of this shark attacking the whale-fisher, although he frequently slips into the water where they abound. It uses its tail only in swimming, the other fins are spread out to balance it, and are never observed in motion but when some change of direction is required.

Sawfish. Page 102.

Pristis antiquorem-Saw-fish.

Mr. Laing gives an instance of its insensibility to injury ; it occurred on a whaling voyage at Spitzbergen. "During the flinching of the whales, ... a saw-fish, ... more voracious than the rest, approached close to the side of the whale's carcase, and seized a large piece of blubber, which was ready to be hoisted on board. Before he could make his escape, however, he was struck by a harpoon, and, his flight being thus obstructed, he was attacked with spears; a tackle was immediately fastened to his jaws, and being hoisted on deck, his belly was ripped open and the blubber recovered. The carpenter, too, stripped a considerable quantity of skin from his tail. Notwithstanding this rude treatment, he was no sooner lct down than he swam away with great agility." Account of a Voyage to Spitzbergen, pp. 139, 140. 


\section{CRISTALEA.}

LITHODES ARCTICA.

This secms to be the sea-spider? mentioned in Martens. Sce page 91 .

Garnels or Prawns. Page 92.

Crangon Boreas.

Abundant in Spitzbergen seas : first described and figured by Phipps (p. 190, tab. 12, f. 1), from a specimen found in the stomach of a seal. It was found very abundantly on Parry's expedition in the shallow water to the westward of the Low Island of Phipps. Kroyer (Nat. Tidsk, iv, 218, 2.31, t. iv, f. 1-14) has given a detailed description and figures of it.

\section{Sabinea septemcarinata.}

Found on Parry's expedition in considerable numbers off Red Beach and the Low Island of Phipps. Kroyer has also described and figured this (Nat. Tidst, iv, 2t4, tab. 4, f. $34-49$; tab. 5, f. 41).

\section{Hippoltte Gaimardi.}

Spitzbergen. (Kroyer, Nut. Tidst, iii, 5\%2.)

IIPPOLTTE GIBEA.

Spitzbergen. (Kroyer, Nut. Tidsk, iii, 5\%..)

II PPOLYTE Sowerbei.

A British species also found in Spitzbergen. (Kroyer, Nat. Tidsk, iii, 573.)

IIPPOLYTE TURGIDA.

Spitzbergen. (Kroyer, Nat. Tidsk, iii, 575.)

II polyte Phippsit.

Spitzbergen. (Kroyer. Nut. Tidst, iii, 575) 
IIIPPOLYTE POLARIS.

Low Island of Phipps in great numbers : some individuals were found as far north as $82^{\circ}$ on Parry's expedition. (Ross, Appendix, p. 206 ; Kroyer, Tidsk, iii, 577.)

HIPPOLYTE BOREALIS.

Spitzbergen. (Kroyer, Tidsk, iii, 5\%7.)

Hippolyte aculeata.

Spitzbergen, westward of Low Island. (J.C. Ross, 1. c. 206.)

Calanus Spitzbergexsis.

Spitzbergen. (Kroyer, Tidsk, ii, 531.)

Calanes hyperborecs.

North Coast. (Kroyer, 1. c., p. 542.)

Catanos mixutus.

West Coast. (Kroyer, l. c., p. 543.)

Calants affixis.

Spitzbergen. (Kroyer, l. c., p. 544.)

Cetochilus arcticus.

Spitzbergen. (Figured by Scoresby, pl. 16, f. 15.)

Talttres Edvardsir.

Found abundantly on Parry's expedition : some dead specimens are mentioned by Sir James Ross as having been found on the loose ice to the northward of the Seven Islands in lat. $82^{\circ} \mathrm{N}$.

\section{Arovyx Anpulat.}

Spitzbergen. First described and figured in Phipps' Voyage, p. 191, tab. 12, fig. 3, from a specimen found in the stomach of a seal. It would seem to form a favourite portion of the seal's food, as on Parry's expedition specimens were found also in the stomach of a young seal.

LYSIANASSA NUGAX.

First found near Moffen Island on Phipps' expedition, p. 
192, tab. 12, fig. 2. On Parry's expedition it was taken off Low Island and in Hecla Cove abundantly.

Acanthonotus inflates.

Bell Sound. (Kroyer, Tidsti, iv, 161.)

Gammarus Sabini.

Found on Parry's expedition in latitude $81^{\circ} 6^{\prime} \mathrm{N}$.

Gammarus loricatus.

On Parry's expedition found on the shores of Walden Island amongst sea-weed.

\section{Gamirus Boreus.}

Found on Parry's expedition abundantly on the shores of Low Island and in Hecla Cove. A dead specimen was found on the ice in latitude $82^{\circ} \frac{1}{4} \mathrm{~N}$.

\section{Gamalius arcticus.}

This species is figured in Scoresby's Arctic Regions, pl. 16, f. 14. In that work (i, p. 541) the author observes, "the actions of this species suggest as a familiar name, the mountebanti shrimp. It frequently turns over when in the water with singular celerity, and swims with equal ease in every position. The four feet raised in the figure above the back, are made use of in that position whenever its back comes in contact with any solid substance. This species occurs in all parts of the Spitzbergen sea, and at the greatest distance from land; it inhabits the superficial water, and affords food for whales and birds."

\section{Gammares?}

Scoresby alludes to another small amphipod remarkable for the largeness of its eyes, large quantities of which were found in the stomach and mouth of a whale; so that these ereatmes, it is evident, fecd also on small crustacea.

LEUCOTHOE GHACHIS.

Bell Sounc. (Kroyer, Tidst, iv, 159.) 


\section{Metects Medesinum.}

It is either this or M. cy Ax. which Martens alludes to as found in the cavities of one of the sea-blubbers (medusa). As Mr. Gosse observes of an allied species found on the Devonshire coast, this singular amphipod "makes these chambers his residence, dwelling in them as in so many spacious and commodious apartments, of which he takes possession, withont asking leave of the landlord, or paying him cven a peppercorn rent. There, however, he sungly ensconces himself and feels himself so much at home, that he is not afraid to leave his dwelling now and then to take a swim in the free water, returning to his chamber after his exercisc."-Nuturalist's Rambles, p. 367.

\section{Caprelila Scolopexthordes.}

Taken to the northward of Low Island on Parry's expedition.

\section{Cxanus ceti-Whale-louse.}

Found on the whale prineipally under the fin, or in situations where it is not likely to be dislodged. Scoresby refers to a similar animal, but smaller, being sometimes found on the body of the narwhal (Aretic Regions, i, 543).

\section{Arcturus Baffixi.}

Taken abundantly off the west side of Low Island, on Parry's expedition (App., p. 203).

\section{TAXAIS GRACILIS.}

Spitzbergen. (Kroyer, Tidsli, iv, 18..)

\section{LERTEOPODA ELONGATA.}

Attached to the cyc of the Gircenland slark. Scoresby, in his Aretic Regions, i, p. 538, pl. 15, fig. 5, describes and figures this as a portion of the eye of the shark; he says, "to the posterior edge of the pupil is attached a white vermiform substance, onc or two inches in length. Each 
extremity of it consists of two filaments; but the central part is single:" this substance is the Lernœopoda.

\section{LERNEA CYCLOPTERINA.}

This seems to be the species found by Phipps in the gills of the "Cycloptcrus Liparis," and not the "L. branchialis," a parasite apparently confined to the species of the cod and haddock family.

\section{NYMPHON GROSSIPES.}

Spitzbergen. (Parry's Expedition.)

\section{NYMPHON HIRSUTUM.}

Found abundantly on Parry's expedition in the l'olar Sca to the north ward of the Seven Islands.

\section{CIRRIPEDIA.}

\section{Balanes Tintingabulum.}

Smeerenberg Harbour (Phipps, 197).

'This species is mentioned by Phipps as having been picked up on the beach of Smeerenberg Harbour; it was much worn and broken, and he was uncertain whether it was a native of these seas, or had been brought there by accident. In the Arctic seas this, or an allied Balanus of equal size, has been subsequently met with alive.

\section{INSECTS.}

Scoresby says (Aretic Regions, i, 131), "the only insect I saw was a small green fly, which swarmed upon the shingle about the beach"; this was near Mitre Cape.

Sir J.C. Ross (Appendix, Parry's Narrative, p. 201) refers to "the only insect that was obtained during the royage"; it was a species of aphis or plant-louse, described by $\mathrm{Mr}$. 
Curtis as Aphis borealis. Sir James remarks : "The circumstance of the Aphis borcalis having been found on floating floes of ice in the Polar Sea, at one hundred miles distance from the nearest known land, and as far north as $82^{\circ} \frac{3}{4}$, renders it in a more than ordinary degree interesting. Its very near resemblance to the Aphis Pice, which feeds on the silver fir (Pinus Picea, $L$ ), whence it derives its name, would induce the belief that the floating trees of fir, that are to be found so abundantly on the shores and to the northward of Spitzbergen, might possibly be the means by which this insect has been transported to the northern regions. It was never seen on the wing, and the fow specimens that were obtained were in a very languid state, but revived by the heat of the hand."

$$
A N N E L I D A \text {. }
$$

Serpula triquetra.

Smeerenberg Harbour, adhering to dead shells (Phipps, p. 198).

\section{SPIRORBIS SPIRORBIS.}

Smcerenberg Harbour, abundant, sticking to the stones and dead shells.

SABELla Fintstulusa.

North side of Spitzbergen (Phipps, p. 198).

\section{MOLL USCA.}

Chio borearis-Sea May-Flye. Martens, p. 135.

This species occurs, according to Dr. Scoresby, "in vast numbers in some situations near Spitzbergen, but is not 
found generally throughout the aretic scas. In swimming it brings the tips of its fins almost into contact, first on one side and then on the other. I kept several of them alive in a glass of sea water for about a month, when they gradually wasted away and died."-Arctic Regions, i, 544. Phipps remarks: "Our fishermen call them by the name of whale food, and are of the same opinion" with Martens, who says they are the chief food of the whalebone whale (App., p. 196).

Limacina arotica-Snail Slime-Fish. Martens, p. 136.

Found in immense quantities near the coast of Spitzbergen, but secms to be rare, according to Dr. Scoresby, out of sight of land. Sir James Clarke Ross remarks that, on Parry's Polar expedition, this species and the preceding were very numerous "as far as $81^{\circ} \frac{3}{4} \mathrm{~N}$, towards the end of August, affording abundance of food for the numerous water fowl which, at this season, are preparing to migrate with their young to the southward" (App., p. 206). In Greenland, according to Otho Fabricius (Faun. Groenl, p. 389 ), it forms the food of whales, and when eatcn by the Cottus Scorpio, renders the fish insipid as food to the natives. That anthor gives the following account of its habits, the translation is that of Dr. Johnston, in his Introduction to Conchology. "The shell is its boat, which the snail rows admirably through the water by the regularly timed strokes of the raised fins. In this act the open extremity of the shell is the prow, the opposite end occupies the place of a poop, and the margin of the body whorl resembles and performs the office of the keel. I have often seen it with admiration and pleasure. He can move in a retrograde manner. When weary with rowing, or when touched, the little boatman contracts its oary fins, and drawing itself within the shell, sinks to the bottom, where it rests a short space, either upon the kecl, or the prow, or the vertex, but never on the umbilicus. 
Then again it rises upwards, rowing obliquely until the surface has been gained, where its course is held in a straight line orer the trackless surge." He adds, that when taken ont of the shell, althongh without injury and in the water, it inmediately dies" (Fanna Gronlandica, pp. 388, 389).

BuccixuM CARINATUM.

First described and figured in Phipps' Voyage, from specimens found on the beach at Smcerenberg Harbour (App., p. 19ז).

\section{Beccisum glaciale.}

Spitzbergen : found too, occasionally, off the coast of Shetland (Floming's Brit. Animals, p. 343).

Margarita helicita.

North side of Spitzbergen (Phipps, p. 198).

Chiton ReBer.

"Coat of mail shell", taken in the trawl on the north side of Spitzbergen (Phipps, p. 19\%).

Mytilus Regosus.

Beach at Smecrenberg (Phipps, p. 197).

\section{AIXA TRUNCATA.}

Beach in Smecrenberg Harbotir (Phipps, 1. c. 197).

\section{Paxdora giacialis.}

Spitzbergen (Leach, App. to Ross's Voyage, ii, 174).

MACONA TENERA.

Spitzbergen (Leach, l. c. ii, 175).

Crassixa semisulgata.

Spitzbcrgen (Leach, l. c. ii, 175).

Nicaita Banksit.

Spitzbergen (Leach, 1. c. ii, 17.5). 


\section{TEREBRATULA CAPUT-SERPENTIS.}

Spitzbergen.

Terebratella spitziergexsis.

Spitzbergen (Dr. Gray, Cat. of Mollusca in Brit. Mus., p. 91).

\section{SYNOICUM TURGENS.}

North side of Spitzbergen, taken up in the trawl. This new genus and new species, belonging to the 'Tunicated mollusca, was found on Phipps' expedition. It is described and figured in the appendix of the narrative of that voyage (pp. 190, 200, tab. 13, f. 3). For a more detailed account of this curious genus, with dissections, see Savigny's Memoires sur les animaux sans vertèbres, ii, pp. 180, 181, pl, xv.

Ascidia getativosa \& A. rustica.

North side of Spitzbergen (Phipps, pp. 194, 195).

\section{RADIATA}

E C I I N O D E R M A T A.

Asterias papposa.

Found during the expeditions of Phipps and Parry.

Astertas rubens.

North side of Spitzbergen (Phipps, 196).

Asterias gLACIALIS.

During Parry's expedition some very fine specimens of this sea-star were taken in a drag net, from a depth of eighty fathoms in lat. $81^{\circ} 6^{\prime}$ N. (Sir J. C. Ross. App., p. 203.)

\section{OPHIOLEPIS FRAGILIS.}

North side of Spitzbergen. 'This seems to be one of the species described in Martens. 
Comatula pectirata.

North side of Spitzbergen; taken in the trawl (Phipps, p. 196).

Astrophytor arborescens.

Spitzbergen. "The Second Star-fish," described and figured by Martens.

\section{ENTOZOA.}

Echinorhysehes polymorphes.

This species (figured and described in Phipps, p. 194, tab. 13, f. 1, under the name of Sipunculus Lendix), "was found adhering by its small snout, to the inside of the intestines of an eider duck. Mr. Hunter, who at my request dissected it, informed me that he had seen the same species of animal adhering to the intestines of whales." Other species of intestinal worms have been met with in these seas (see Scoresby, i, p. 543).

\section{ACALEPH A.}

Cydippe (Beroe) pileus.

"Slime Fish like a Cap." Nartens, p. 138.

'This species is found in great abundance as far north as 82 .

\section{Cydipe ovur.}

This species was seen abundantly on Parry's expedition amongst the loose ice to the northward of Spitzbergen, and as far north as the expedition went (p. 202).

Miedesa Infuxdibutum, or an allied species.

"Slime Fish like a Fountain." Martens, p. 138.

There seem to be other species of Acalephr in the Spitzbergen seas. Some of these are roughly figured in plate 16 of Dr. Scoresby's work. Most of them are very small and very abundant. 'They are found chiefly in the sea water, of an olive-green colour, and also occur, but in smaller quantities, in the blueish green water. Dr. Scoresby remarks: 
"The number of mednse in the olive-green sea was found to be immensc. They were about one-fourth of an inch asunder. In this proportion, a cubic inch of water must contain 64 ; a cubic foot 110,592 ; a cubic fathom $23,887,882$; and a cubical mile about $23,888,000,000,000,000 !$ From soundings made in the situation where these animals were found, it is probable the sea is upwards of a mile in depth; but whether these substances occupy the whole depth is uncertain. Provided, however, the depth to which they extend be but two hundred and fifty fathoms, the above immense number of one species may occur in a space of two miles square. .. What a stupendons idea this fact gives of the immensity of creation, and of the bounty of Divine Providence, in furnishing such a profusion of life in a region so remote from the habitations of men" (p. 179). "The economy of these little creatures... constitutes the foundation of the subsistence of the largest animals in the creation... The common whale feeds on medusæ, cancri, actinix, sepiæ, etc., and these feed probably on the minor medusx and animalcules. The fin whales and dolphins feed principally on herrings and other small fishes! These subsist on the smaller cancri, medusx, and animalcules. The bear's most general food is probably the seal; the seal subsists on the cancri and small fishes; and these on lesser animals of the tribe, or on the minor medusa and animalcules. Thus the whole of the larger animals depend on these minute beings... and thus we find a dependent chain of existence, one of the smaller links of which being destroyed, the whole must necessarily perish. It is not a little interesting to trace the physiology of the preservation of these smaller animals. As the mean temperature of the atmosphere in the Spitzbergen Sea is ten or twelve degrees below the freezing point of salt water, it is evident, that, were the water of the sea stationary, it must, in the course of ages, be frozen to the bottom, and along with it, as a matter of course, all the smaller animals, not having 
sufficient instinct or power of motion to enable them to retire into a more sonthern region. Now, sueh an event is provided against, by the constant prevalence of a current setting towards the south-west, which carries away the ice into a parallel where it can be dissolved, and oceasions a circulation of water into the frozen regions from a warmer chimate. And this circulation of the water is beautifully accomplished; for, while the superficial current is performing its office, in carrying away a portion of ice, an under-current setting to the northward, is acting an equally important part in affording warmth to the seas of the higher latitudes, and preventing the too great accumulation of the ice. But how is it, it might be asked, when a current in the waters, inhabited by the minor medusa, is constantly setting to the sonthward, that these animals are not carried away into a southern region altogether? This question, if we may be allowed to argue hypothetically, admits of an easy solution. Animals, we find, when possessing any power of moring, though they be of the most imperfect kind of organization, gencrally employ that power by a sort of instinctive faculty, as may best serve the purposes for which they were called into existence. Now, it would be no streteh of commonly received principles, to suppose, that whenerer the minor medusæ, etc., are carried to a certain extent southward, they may sink in the water as far as the stream of the under-current, and by it be conveyed back again into their proper element. 'The fact of the olive-green coloured sea water maintaining a great similarity of position, for many years together, while surface after surface of ice is carried away by the current and dissipated, is in support of this conjecture. 'Thus, by a most bcautiful contrivance, a large portion of the surface of the globe is rendered habitable, which would otherwise be a solict mass of ice, and by the warmth of the lower stratum of the Polar Sea it is rendered congenial to many tribes of animals which must, otherwise, have incumbered other re- 
gions, now affording products useful for the subsistence of man" (Scoresby, Arctic Regions, i, 546-548).

\section{POLYPI.}

MILLEPORA POLYMORPHA.

Smeerenberg Harbour (Phipps, p. 198).

Cellepora pumicosa.

Smeerenberg Harbour (Phipps, p. 199).

Axyulipora PILOSA.

Smeerenberg Harbour, adhering to stones (Phipps, p. 200). Flustra membranacea.

Smeerenberg Harbour (Phipps, p. 200). 


\title{
LIST OF 'THE PLANTS OF SPITZBERGEN.
}

\author{
Chiefly from the Calalogue given by Sir W. J. Ilooker in \\ the Appendix to Parry's Voyage.
}

Ranunculus nivalis

$$
\text { sulphureus }
$$

sceleratus

,

Papaver nudicaule

Draba alpina

, lapponica

, hirta

Cochlearia fenestrata?

" $\quad$ Danica

Platypetalum purpurascens

Parrya arctica

Cardamine bellidifolia

Silene acaulis

Lychnis apctala

Cerastium alpinum

Stellaria leta

humifusa

Spergula saginoides

Arenaria rubella

Saxifraga oppositifolia

" $\quad$ dlagellaris

aizoides

rivularis

crespitosa

foliolosa

nivalis-"Small House-

leck." Martens, p. 47 cernua

tricuspiclata? "Plant

"tricuspicitata ?

with aloe leares." Martens, p. 46

Dryas octopetala

Potentilla julchella

, nivea
Leontodon palustre

Andromeda tetragona

Pedicularis hirsuta

, arctica

Polygonum viriparum

Oxyria reniformis

Salix herbacea

\section{Luzula hyperborea}

Carex fuliginosa

Eriophorum capitatum

Poa abbreviata

$$
\text { arctica }
$$

Phippsia algida

A small grass, the Agrostis algida of Phipps, p. 200, 201, constituting the type of a new genus, named by Mr. Brown in honour of Captain Phipps (Lord Mulgrave).

Festuca brevifolia

Dupontia Fisheri

Hierochloe pauciflora

ACOTXLedoNes.

Lycopodium Selago

Equisetum variegatum

Bryum palustre

" turgidum

" crudum

, cœspititium

, turbinatum

$-\mathrm{sp}$ ?

Cynclidium stygium

IIypum nitens

, aduncum 
Iypnum cupressiforme uncinatum ?

Trichostomum lanugiuosum

Dicranum virens

IV"eissia crispula fuscescens

Conostomum boreale?

Polytrichum septentrionale alpinum

splachnum Adamsianum

Voitia hyperborea

Jungermannia minuta
, scalaris

Gyrophora tesselata

$\begin{array}{ll}" & \text { cylindrica } \\ " & \text { erosa } \\ " & \text { deusta } \\ , & \text { vallea }\end{array}$

Lecanora tartarea

,$\quad$ elegaus

Parmelia saxatilis

" miniata ?

Cetraria nivalis " eucullata

" islindica. "Iceland moss."

"Immense quantities (of this lichen) are gathered in Iceland, not only for sale, but for their own use as an article of common food. The bitter and purgative quality being extracted by steeping in water, the lichen is dried, reduced to powder, and made in to a cake, or boiled and eaten with milk, and eaten with thankfulness, too, by the poor natives, who confess that a bountiful Providence sends them bread out of the very stones."-Hooker, English Flore, v, 221.

leltidea aphthosa

$$
\text { " canina }
$$

Cenomyce alcicornis

$$
\text { " } \quad \text { pyxiclata }
$$

Cladonia rangiferina, the Reindeer moss. "It is this lichen which, for the greater part of the year, and especially in winter, is the support of the rast herds of reindeer, wherein eonsists all the wealth of the Laplanders....... Whatever may be the depth of snow during the long winters of that climate, these creatures have the power of penetrating it and obtaining their necessary food." -Hooker, English Flora, v, p. 235.

Cladonia vermicularis

Isidium oculatum

Stereocaulon paschale

Sphærophoron fragile

Alectoria jubata

coralloides

Cornicularia jubata

$\begin{array}{ll}" & \text { odontella ? } \\ " & \text { ochroleuca } \\ & \text { lanata }\end{array}$

Ulva crispa

Ptilota plumosa

Protococcusnivalis, the "Red Snow." Sir W. Ilooker, in reference to this most curious production remarks, that on Capt. Parry's expedition it was found "in greater abundance, perhaps, than on any former occasion, and in a situation still more remarkable; for it was upon the floes of ice extending nearly to the utmost limit of the journey, and there, too, in such abundance, and so completely imbedded in the snow, that distinct red lines were left by the traeks of the boats or sledges on the surface; thus vegetating in the most northern regions to which man has yet been able to penetrate, and flourishing most in an element (or rather a state of an element) in which no other regetable that we are acquainted with can exist."

Fucus digitatus

Hlalymenia jalmata?

Laminaria sp ? 



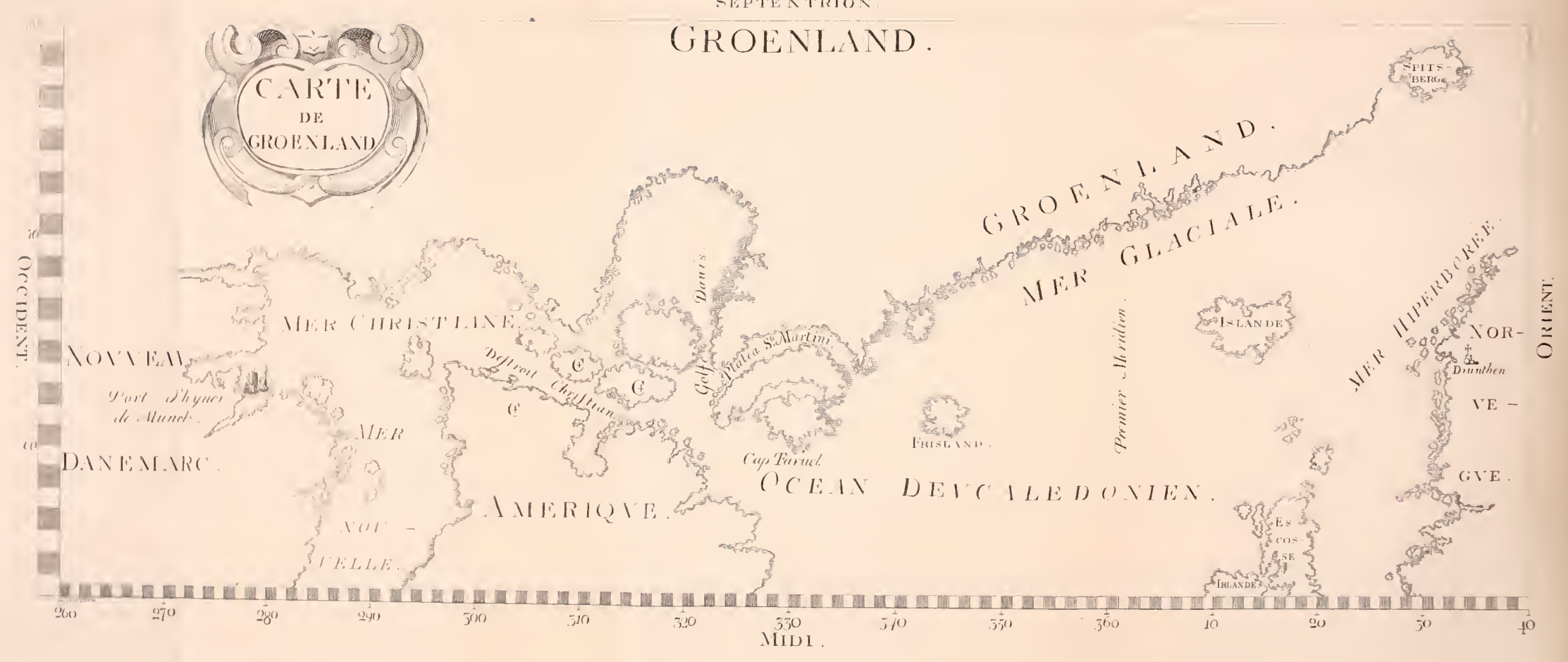


DESCRIPTION

OF

G R E E N L N D . 


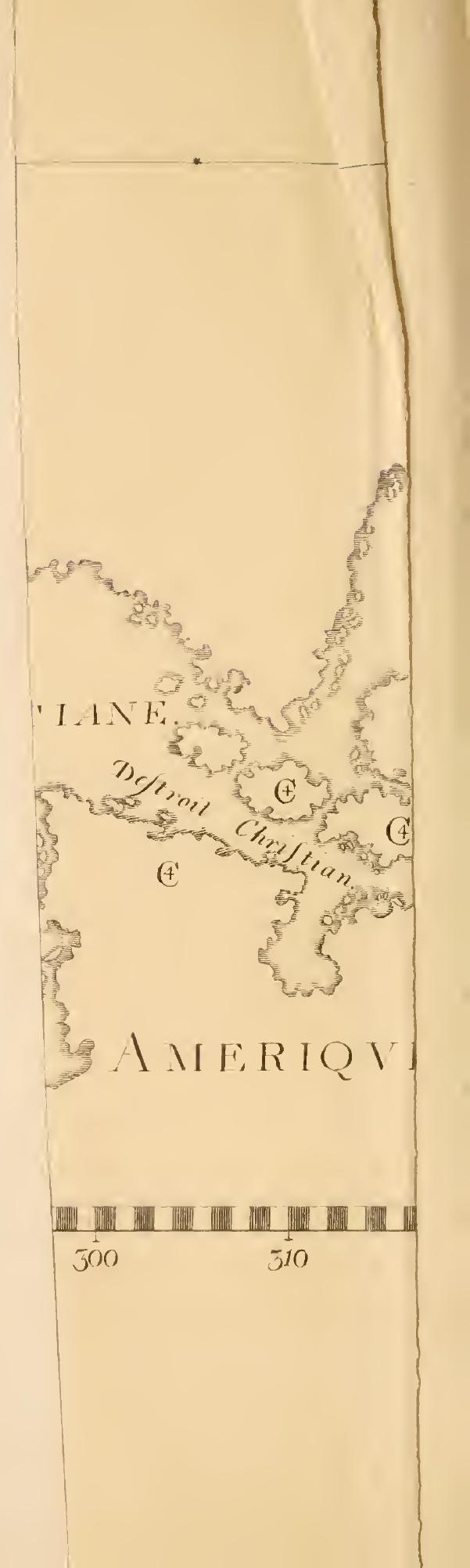


DESCRIPTION

OF

G R E E N L A N D. 



\section{RELA'ION}

DU

\section{G R O E N $\mathbb{N} \mathbb{D}$}

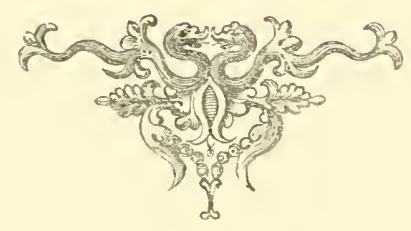

A PARIS:

Chea THOMAs JOLLY, dans la petite Salle des Merciers, au Palais, a la Palme, et aux Armes de Hollande.

m.dc.lxiii.

Avec privilego du Roy. 



\section{NOTE ON TILE MAP OF GREENLAND.}

I may say that M. Chapelain is the real author of this map, because he gave it as his opinion that it was absolutely necessary for the illustration of my narrative, and I could not do wrong in following the adviee of a person who has attained such high and universal approbation. I have drawn this map on four clecations which wore voll-kinown to me, viz., Cape Farewell, Iceland, Spitzbergen, and that part of the Christian Sea where the ice arrested the progress of Captain Munck, which is here laid down and called Port of Muncl's Winter.

I hate talien the longitudes of all these places upon the meritian of the Island of Ferro, in the Canaries, by the advice of M. Roberval, a mathematician of great fame, and of $M$. Sanson, an excellent gcographer, whom I have consulted upon the construetion of this map. I have ascertained the longitude of the Port of Huncli's Winter more preciscly than the others, from an eclipse of the moon, which is mentioned in the captain's oun account, which states, that being at this port, he saw it at cight o'clocli in the evening, December 20 th, 1619. It must have appeared at Paris, according to the tables of the movcments of the heavenly bodies, at three o'clock in the morning, or thereabouts, on the 21st of the same month; but as this ectipse lasted three hours or more, and as Cuptain Munct: does not say whether he sazo it at the commencement, middle, or end, M. Gassondy (to uhom I had recourse touching this difficulty, and whose capabitity is linoun among all those who profess a regard for belles-lettres) adised me, for the sulie of cnsuring an approximation to truth in my conjecturcs, and in order not to full into the one or other extreme, to suppose that 
this eclipse was apparent at Muncli's Port between its commencement and its end, that is to say, toucards the middle of the time that it lasted and at the liour, or thereabouts, that it should have been seen at Paris; whence it will result, that when it is three o'clock in the morning at Paris, it is only eight o'clock in the evening of the preceding day at Muncli's Port, and that there are seven hours difference between one place and the other.

Now, by taking fifteen degrees for each hour, according to the rules of science, it will follow also that the meridian of Muncli's Port will be distant from the meridian of Paris one hundred and fice degrees; and that, placing Paris in the tu:enty-thivd degree and a half of longitude, Muncli's Port should be placed in the two hundred and scronty-eighth degree and a half, that is to say, eighty-one degrees and a half beyond the meridiun of the Canaries. And ii will be evident by the same reasoning, that if we reckon tuctre common French leagues to each degree of this parallel, the degrees of which are smaller by about half than the degrees of the great circles, this port will be distant from Paris one thousand two hundred and sixty leagues. I have divided the southern part of Greentand, tatien at Cape Farevell, into two istends, in the manner in which they ure here represented. This I hace done, not from the Danish accounts, of which I hare made use for my history, for they do not speak of it, but from a map) in the library of Cardinal Wazarin, which M. Naudé (who is the soul of the great collection of excellent boolis and curious researches of which that distinguished library is composed) did me the fucour to show me. At the bottom of this map the following words are written :-

Hace detineatio fucta est per Hartinum filium Armoldi nalum in Hollandia, Civitate dieta den Briel qui bis navigationem ad insulam dictam antiquam Groenlandiam, instituit; tanquam supremus Gubcrnator, ano. 1624 \&. 1625.

'This Marlin, son of Amold, ralls Gircentand an istant, 
although it is not yet linown whether it be an island, or a continent, or a group of islands. ITe says that it is the map of Old Greenland; he might say of the Old and of the New, for no other is kwoun; and that which we know ought rather to be called New than Old. The reason is, that whilst Old Greenland has eertainly been placed in some part of the land here described, and to the west of Iceland, yet they have nover bcen able to determine its locality, which is not now linown exen by the Noruegians, although their fathers discovered it and inhabited it for whole centurics; as will be more particularly shown in this history.

That which is heve represented of the junction of Cape Furewell with the Christian Strait and the Christian Sea and the Port of Iunch's Winter, has been taken from a map that Captain Huncli caused to be constructed on his voyage, and which is reprinted with his narrative. I have followed it the more willingly that it agrees with the map of Captain Hudson himself, who first discovered this strait and sea, which 1I. Chapelain, a man whose courtesy equals his research, lent me from his own cabinct, that I might compare it at leisure with Captain Muncli's map.

I dure not assert that all the coast of the Christian Sea, as well as the West Const as here described, between Daris Gulf and the Pori of Muncl's Winter, is part of Greenland, because it may be that there is some considerable river or some strait which I lo not hnow of, that intersects this land and separates Greenlund from America. What renders me more undecided upon this point is, that I have not heard in Thenmert: that aill this coast was part of Greentund, as I have hecird it stated of all the north-east coust between Cape Farewell and Spitabergen. I leave the solution of this doubt to those who will hnow more about it from English and Duteh narratires, as my present design is only to writo what I have learned of this land from Danish books and from conversativns that I have had in Thenment. 


\section{DE LA MOTHE LE VAYER.}

SiR,-I see plainly that I must not content mysclf with having written you a long letter on Ieeland : but I must also keep my promise, and send you a description of Greenland. Do not be astonished at the length of time I have allowed to elapse between the two; for if you consider the difficulties and the perils that have to be encomntered in that navigation, you will find that I was right in not hurrying, but informing myself at leisure of the route I must take to find this northern country, which better merits the name of unknown than Australia does, not but what the Norwegians have dwelt there and for the space of five or six hundred years have carried on commerce and established colonies therein. Let me not, however, confuse the order of my narrative by putting at the head of this work that which should constitute the body of it. I will tell you what I have learned of this land, with all the information I could gather from what has been told me, and what I conld understand from writings of a very confused character, not that I can say that I read them myself, but they were explained to me from a language that I do not understand; such as the Danish books which M. Rets, a Danish gentleman, has had the kindness to read and explain to me. You will see him soon at Paris, for the ling of Denmark has appointed him, on account of his worth and deserts, to be his ambassador to France, and he will confirm what I am going to write. 


\section{DESCRIPTION OF GREENLAND.}

Greexiaxd is that northern land which runs from south to cast, extending northwards from Cape Farewell in the Dencaledonian Ocean, along the coasts of the Arctic Sea which trend towards Spitzbergen and Nova Zembla. Some say that it extends so far as to join the regions of Tartary; but this is uncertain, as you will hereafter perceive. It has, then, on the east the Aretic Sea; on the south the Deucaledonian Ocean; on the west, Hudson's or Christian Straits, and the Sea of Hudson or Christian which separates it from America. Its length on the northern coast is unknown. 'The Danish Chronicle on this head states, that it forms the northern extremity of the world, and that beyond it there is no more northern land to be found. There are some who think that Greenland is part of the American continent, since the time when the English, in an attempt to pass through Davis Straits with the view of discovering a passage into the East by that route, found that what Davis had taken for a strait was a gulf. I have, however, a Danish narrative, by a Danish captain named John Munck, who tried this passage to the East by the morth-west of the Gulf of Davis, and according to what he says there is great probability that this land is entirely separated from America. This I shall show you in due time when I come to speak of that royage.

The elevation of Greenland taken from Cape Farewell, which is its most southerly point, according to the calculation 
of Captain Munck, a most intelligent navigator, is sixty degrees thirty minutes. The other parts are much more elevated as they approach nearer the Pole. I have no fixed datum as to the elevation of Spitzbergen, which the Danes reckon as part of Greenland, and say that it is in seventy-cight degrees or thereabouts. I say nothing of the longitude of this country, because my accounts do not mention it, and because I have learned nothing more definite than what our maps tell us. It will suffice for me to remark, that Cape Farewell is beyond the Canaries and our first meridian. I have chiefly used for the history of Greenland two chronicles, the one Icelandic and the other Danish; the former ancient, the latter modern; the former in prose, the latter in verse, and both in the Danish language. The original of the Icelandic one, however, is in Icelandic, composed by Snorro Storluson, a native of Iceland, who was Nomophylax, as Angrimus Jonas calls him, that is, sovereign judge of Iceland in the year 1215. This is the same who compiled the Edda, or the fables of Icelandic poetry, of which I have at other times spoken to you. The Danish Chronicle was composed in Danish verse, by a priest named Clandins Christopherson, who dicd fiftecn years ago or thercabonts. This chronicle states that some Armenians, driven by a tempest, were carried into the Northern Occan, and landed by chance in Girecnland, where they remained for some time and passed from thence into Norway, where they inhabited the rocks of the Hyperborcan Sea. That, however, is only founded on fable, and the old habit of making people come from remote countries to establish colonies. A more anthentic and certain account is that the Norwegians discovered Greenland, and that they went over thither and dwelt there in the mamer described.

A gentleman of Norway named Torwald, and his son Eric, surnamed the Red, having committed murder in Norway, fled to Iceland, where Torwald died. His son Eric, who was of an impatient and fiery temper, shortly after killed 
another man in Iceland, and not knowing whither to flee to escape the severity of the judges who pursued him, resolved to scck a land which a man named Gundebiurne told him he had seen to the west of Iceland. Eric found this country and landed thereon at an opening formed by two promontories, one of which was at the end of an island facing the continent of Greenland, and the other on the continent itself. The promontory on the island is called Huidscrken; that on the continent, Huarf; and between the two there is a good roadstead, called Sandstafin, where vessels may ride in great safety in bad weather. Huidserken is a prodigiously high mountain, beyond all comparison higher than Huarf; Eric the Red called it at first "M[ukla Jokel", that is to say, the great icicle. It has since been called "Bloserken", which is as much as to say, blue shirt. And, again, "Huidserken", which signifies white shirt. The reason for these two last changes of name is probably this, that the snow, by melting and freezing at the same time, composes at first an ice, which is the colour of moss or grass, or of the little trees which grow upon these rocks; but as after repeated falls of snow, heaping themselves in layers one upon the other, the ice becomes extraordinarily thick, it resumes its pristine colour and the whiteness which is natural to it. This observation is based upon my experience of what occurs in Sweden, where I have seen rocks which from the same cause appeared first a pale blue and afterwards white. I can positively assure you, and the ambassador will confirm the truth of what I say, that in returning this very winter from Sweden to Denmark, and passing in a sledge over the sea between Elsinore and Copenhagen, we saw large blocks of ice heaped up in different places, whole piles of which appeared to us, some very white, others as if tinted with the most beautiful azure that could be seen. We could find no explanation for this phenomenon, for they were all formed from the same water, and we saw them all from a point of 
view which did not seem to us sufficiently different with respect to each to cause this difference of colour. It reminds me of those lines of Virgil, where he speaks of the frozen zones in the following words:-

"Cœrulea glacie concretæ, atque imbribus atris."

But I think that Cerulea glacies ought to be taken in this place for black ice, such as Virgil has figured to himself in the black and dark countries; as where the poet says in another place :-

" Olli coruleus supra caput adstitit imber."

And also :-

"Stant manibus arre

"Cœruleis mæstæ vittis atraque cupresso."

To return to our subject. Before undertaking anything upon the contiuent, Eric the Red thought fit to reconnoitre the island and landed there. He gave it the name of Ericsun, which means the Island of Eric, and remained there all the winter. When spring came he left the island for the continent, which he called Groenland, that is to say, Greenland, because of the verdure of its pasturage and of its trees. He landed at a port which he called Ericsfiorden, that is to say, the Port of Eric, and not far from this port lie construeted a dwelling, which he named Ostrebug, or the building of the East. The following antumn he went to the western coast, where he built another dwelling and called it Vestrebug, or building of the West. But, cither because the climate of the continent appeared to him colder and more severe than that of his own island, or that he found less safety there, he returned the next winter to Ericsun. In the summer following he again went to the continent, and procceded to the north coast to the foot of a large rock, which he called Sneficl, or rock of snow. And discovered a port, to which he gave the name of Ravensfiord, that is, the port of the crows, from the number of crows he found therc. 
Ravensfiord answers on the north side to Ericsfiorden on the south. And one may cross from one to the other by an arm of the sea which connects them. Eric returned again to his island at the end of autumn, and there passed the third winter. On the return of spring he determined to go himsclf to Iccland, and in order to induce the Icelanders, with whom he had made peace, to follow him to Greenland, he proclaimed the wonders of the land he had discovered. He reported that it abounded in oxen and sheep, in excellent pasturage, and in all kinds of hunting and fishing; and so effectual were his persuasions, that he returned to his conquered country with a great number of vessels and a large retinue of Icelanders. The son of Eric, named Leiffe, haring passed orer from Greenland to Iceland with his father, proceeded thence to Norway, where, according to my Icelandic Chronicle, he found the king Olaus Truggerus, and told him of the excellencies of the country which his father had discovered. This king of Norway, who a short time before had become a Christian, caused Leiffe to be instructed in Christianity, and after having him baptised, persuaded him to remain the cnsuing winter at his court. He sent him back the next summer to his father in Greenland, and gave him a priest to instruct Eric and the people who were with him in the Christian religion. Upon Leiffe's return to his father, he received from the inhabitants of Grcenland the name of Leifflenhepne, which means Leiffe the happy, because he had escaped great dangers in his royage. He met with a cold reception from his father for having brought some strangers with him. These were some poor sailors whom he had found on the keel of their own vessel, which had been struck by a storm and completely overturned upon some rocks of ice out in the open sea. Leiffe, mored with compassion for these poor wretches, having himself suffered from the same tempest, received them into his ship and took them to Greenland. Eric was angry becausc, as he said, Leiffe had 
shown to stranger's the road to the country which he had wished to keep secret from all the world. But the generous son softened the fierce spirit of his father. He told him of those duties of humanity which constitute a man, and then spoke to him of that charity which constitutes a Christian, and begged him to listen to the priest whom the king of Norway had given him. The result was so successful, that he prevailed upon his father and his followers to be baptized. This is all that I have been able to learn of Eric the Red and his son Leiffe, and the first Norwegians who inhabited Greenland.

The Icelandic Chronicle places the departure of Torwold and of Eric his son from the Port of Jedren, in Norway, at the time of Earl Hakon, called the Rich, which is the commencement of this chronicle, and in the reign of Olaus Truggerus, king of Norway, about the year 982. The Danish Chronicle goes further back and places it in 7\%0. I have shown you in my history of Iceland that this latter supposition is more probable than the former, by a bull of Pope Gregory IV, about the year 835, addressed to Bishop Ansgarius for the propagation of faith in all the northern countries, and especially in Iceland and Greenland. I shall not dwell on this dispute, but shall only make two remarks on the subject. The first is, that the same Danish Chronicle states, that the kings of Denmark becoming Christians in the reign of Lonis le Debonnaire, from that time a great stir was made about Greenland. Secondly, that MI. Gunter, sccretary to the lking of Denmark, a learned man of excellent understanding and an intimate friend of mine, told me he had seen in the archives of the archbishop of Bremen an old manuscript chronicle, in which was a copy of the bull which constituted the archbishop of Bremen metropolitan of all the North, especially of Norway and its dependent islands, Iceland and Greenland. He did not exactly remember the date of the bull, but was certain it was before the year of grace 900 . 
The Danish Chronicle says, that the successors of Eric the Red having multiplied in Greenland, went higher up the country, and found amongst the mountains, fertile lands, meadows, and rivers. They divided Greenland into east and west, according to the division that Eric had made by the two buildings of Ostrebug and Vestrebug. They built in the east a town, which they called Garde; to which, says the Chronicle, the Norwegians crery year brought different sorts of merchandise, which they sold to the inhabitants of the country in order to attract them thither. Their children went still further and built another town, which they called Albe; and as religious zeal was increasing among Christians, they erected a monastery on the sea coast in honour of St. 'Thomas. The town of Garde was the residence of their' bishops, and the church of St. Nicholas, the patron of sailors, built in this town, was the dome or cathedral of Greenland. You will find the list of these bishops and their order of succession in the "Specimen Islandicum" of Angrimus Jonas, where he speaks of Greenland, from the time of their establishment to the year 1389. Pontanus, in his history of Denmark, remarks, that in the same year, 1389, a bishop of Garde, named Henry, gave assistance to the states of Denmark which were in Nieuborg, in Funen, on the shores of the Great Belt. Whilst Greenland elevated the kings of Norway in temporal things, the bishops of Drontheim, in Norway, improved them in spiritual things, and the bishops of Greenland went over frequently to Norway to consult the bishops of Drontheim on the difficulties which they experienced. Greenland practised the laws of Iceland under the viccroys whom the kings of Norway established there. You can learn the names of these viceroys, and the exploits of the like Icelandic heroes on the plains of Greenland, in the "Specimen Islandicum", where the good Angrimus, who was a zealous compatriot, has not forgotten them; and to his work I refer you, because, as these gallant deeds have 
already been described in print, I have not thought it necessary to write about them now to you.

The Danish Chronicle states, that in the year 1256 Greenland revolted, and refused to pay tribute to Magnus, king of Norway. Eric, king of Dcnmark, at the request of king Magnus, who had married his niece, fitted out a naval armament for this expedition. The inhabitants of Greenland, seeing the red standards of the Danes and their arms glittering in the vessels, were so terrified that they cried for mercy and sued for peace. The king of Denmark would not take advantage of the weakness of the king of Norway, and left him Greenland for the sake of his niece and grand-nephews. This peace was made in 1261, and Angrimus Jonas, who mentions it, gives the names of the three principal inhabitants of Greenland who signed the treaty in Norway. "Declarantes," says Angrimus, "suis factum auspiciis ut Graenlandi perpetuum tributum Norvego denuo jurassent."

'The Icelandic Chronicle, which is a collection from other histories, contains a chapter entitled, "Description of Greenland", and this description would seem to refer to the most flourishing period of the Norwegian sway in that country. I will give you word for word what is written in this chapter, as it has been translated to me from the Danish; but you must not ask me for dates or chronological order in this history, for I camnot guarantec the one or the other.

The most eastern town in Greenland is called Skagefiord, where there is an uninhabitable rock; and further in the sea is another rock, which prevents vessels from entering unless the tide is high; and at high tide, or whencver there is a riolent storm, this port is filled with whales and other fish, which may then be taken in great abundance. A little further towards the east, there is a port called Funchebucler, from the name of a page of St. Olaus, king of Norway, who, with many others, suffered shipwreck therc. Still higher and in the neighbourhood of the icebergs, there is an island 
called Roansen, where there is much hunting of all kinds of beasts, and among others an abundance of white bears. Nothing is to be seen beyond but ice both by sea and land. On the west coast is Kindelfiord, which is an arm of the sca, and all the coast of which is inhabited. On the right coast is a church, called Korskirke, or a church built in the form of a cross, which cxtends to Petresuik, where also is Vandalbug; and beyond is a monastery, dedicated to St. Olaus and to St. Augustine: this monastery extends as far as Bolten. Near Kindelfiord is Rumpesinfiord, where there is a conrent of nums and several little islands, in which are found a great number of hot-water springs, which are so hot in winter that they cannot be approached. The heat is moderated in the summer. These waters are very wholesome, and many disorders are cured by them. Near here is Eymetsfiord. Between Eynetsfiord and Rumpesinfiord there is a royal residence, called Fos, and a large church, dedicated to St. Nicholas. In Lunesfiord is a promontory named Klining, and further on an arm of the sea called Grantevig. Beyond is a house called Daller, which belongs to the cathedral of Greenland.

The cathedral possesses the whole of Lunesfiord, and particularly the large island beyond Eynesfiord, called Reyatsen, on account of the reindeer which inhabit it. In this island is a stone called talguestein, so strong that fire cannot consume it, and so soft, that they make of it drinking vessels, cauldrons, and tubs, which contain ten or twelve tuns. Continuing onwards towards the west is an island called Langen, in which there are eight farms. All this island bclongs to the cathedral. Near the church of Eynetsfiord therc is a royal house called Hellestad; near that is Ericsfiord, and at the entrance of that arm of the sca is an island called Herrieven, which signifies the Island of the Lord, one half of which belongs to the cathedral, the other half to the church called Diurnes, which was the first church in Green- 
land. And this was to be scen on entering Ericsfiord. The country from Ericsfiord north-west to Midfiord, belongs to Diurnes. Near here is Brudefiord on the north, and on this northern coast there are a great number of islands and ports. The comtry is uninhabited and barren between Ostrebug and Vestrebug. Near this desert there is a church called Strosnes, which was formerly the metropolitan and the residence of the bishop of Greenland. The Skreglinguer or Skreglingres hold possession of all Vestrebug. Horses, goats, cattle, and all kinds of wild beasts are found there, but no inhabitants either Christian or Pagan. Iver Bert states this fact: he was for a long time maitre d'hotel to the bishop of Greenland, and saw all this, being one of those whom the judge of Greenland appointed to drive away the Skreglingres. On arriving there they found no people, but a great number of beasts, and they took away as many as their vessels could hold. Beyond Vestrebug is a large rock, called Himmelradsfield; and farther than this no one dares to navigate, on account of the whirlpools which exist in this sea.

These are the contents of the whole chapter, which I have copied as correctly as I could. Not having a special map of Greenland, or any other history by which to confirm or contradict these statements, I am unable to give any opinion upon it, and therefore give it you as I have received it. What surprises me in it is, that the church of Strosnes, built in the wilds of Ostrebug and Vestrebug, should, since the very beginning of the colonization of Greenland, have been the metropolitan church and the residence of the bishop; for it has never been called in question that it was the town of Garde which had from the first possessed this privilege. 'The Danish Chronicle, regretting the loss of this country, which cannot now be found, asserts that if the town of Garde, the residence of the bishop, were still standing, and one could visit it, there would be found a great number 
of memoirs for a true and extensive history of Grecnland. Angrimus Jonas, also an Icelander, in speaking of this residence says expressly: "Fundata in Bordum (which must be read, in Garden) episcopali residentia, in sinu Eynatsfiord Groenlandic Orientalis." I think the author of this account, though a very good maitre d'hotel, was but a bad writer, for he has not explained who these Shreglingres were against whom he was sent. I will tell you what Doctor Tormius, the most learned of all the doctors in northern researches, told me both verbally and in writing. He says they were the original savages of Greenland, to whom this name was probably given by the Norwegians; but I do not know why. They inhabit, apparently, the other coast of the arm of the Sea of Kindelfiord, on the western side of Greenland, one of the coasts of which was inhabited by the Norwegians. And when this writer says that the Skreglingres possessed all Vestrebug, he only meant the western coast, it not being credible that he should mean the eastern, which was occupied by the Norwegians. Now it is to be presumed that some Norwegian adventurers had passed Kindelfiord in a small number, and were beaten by these Skreglingres. The viceroy of Norway, whom the history, after the Icelandic mode of speaking, calls the "Judge of Greenland", wishing to obtain satisfaction for this affront, sent out a stronger party and fitted out a good ship for this purpose. But the sarages seeing the ressels coming, did as was their custom when they felt themselves to be the weaker party, and fled and hid themselves in the roods, or in rocks and caves. The Norwegians, finding no one on the shore, took all the booty they could lay hands on, and carried it away in their ship. This is what had led this innocent writer to relate, that in the country of the Skreglingres are to be found horses, goats, cattle, and shcep, etc., but no people, either Christian or Pagan. M. Vormius thinks the locality of these Skreglingres was not far from the Gulf of Davis, and that 
they might have been Americans, or possibly the aborigines of New Greenland, discovered by the Danes in the reign of Christian IV, king of Denmark, and of whom I shall speak hereafter. He also thinks that their country bordered on Old Greenland, which the Norwegians inhabited, and that they occupied one part of Vestrebug before Eric the Red took possession of the other.

To tcll you my own notion upon the subject, there was no need of bringing Americans here at all; and the latter conjecture of M. Vormius is very judicious and correct; to which I will add, that by the same reason that Vestrebug had its original inhabitants when the Norwegians arrived there, Ostrebug had them also, and that as the eastern part was nearer the Arctic Sea, was not so fertile, and consequently less inhabited than the west, the Norwegians, who met with less resistance on that side than on the other, took possession more easily of Ostrebug than of Vestrebug. And this is why I do not find in my histories that they made any very persevering attempts at advancing by the westwards; but that they did so to the north, in which direction $I$ observe that they marched eight whole days without discovering anything but snow and ice, of which the valleys were full.

By this you may judge, that the tract of country which the Norwegians took possession of in Greenland was enclosed between the southern and the castern scas, the mountains of the north, which are inaccessible on account of the ice, and the Skreglingres, who arrested their progress on the side of Vestrebug. You will also notice on this subject, that the Icelandic Chronicle affirms as an undoubted truth, that the Norwegians held such small possessions in Greenland, as to have becn only reckoned in Denmark equal to the third part of a bishopric, and the bishoprics of Denmark are not larger than those of France.

M. Tormius thinks the Skreglingres were not far from 
Davis' Gulf, and that they might have been Americans, or perhaps that they were the aborigines of New Grecnland, which the Danes discovered in the reign of Christian $I V$, king of Denmark, and of whom I shall speak hereafter. He thinks that they were on the confines of Old Greenland, which the Norwegians inhabited, and they occupied one part of Vestrebug before Eric the Red seized upon the other. The Danish Chronicle makes the same observation in the following terms:-riz., that the whole of Greenland is one hundred times larger than the portion which the Norwegians possessed, that it is inhabited by a variety of races, and that these races are governed by different lords, of whom the Nortegians never knew anything.

The Icelandic Chronicle speaks in different ways of the fertility of this land, according to the different histories of which it is composed. It states in one place that finer wheat grows there than can be found in any other part of the world, and oaks so vigorous and strong, that they bear acolns the size of an apple. In another place it says, that nothing whatever that is sown will grow in Grecnland, on account of the cold, and that the inhabitants do not know what bread is. This agrees in some measure with the Danish Chronicle, which says, that when Eric the Red entered this country he lived entirely by fishing, in consequence of the sterility of the ground. This same Danish Chronicle, however, states in another place, that the successors of Eric, who went farther into the country after his death, found among the mountains, fertile lands, meadows, and rivers, which Eric had not discovered; and the Icelandic Chronicle, which contradicts itself, is not to be believed in the statement it made before, that nothing grew in Greenland on account of the cold. The reason it assigns makes me doubt what it says ; for it is certain that that part of Greenland which the Norwegians inhabited, is of the same elevation as Lapland, which is the most fertile province of Sweden, and it is certain a great deal of 
fine and good wheat grows there. Added to which, the same chronicle says, and very truly, that for the same reason, viz., that of its elevation, it is not so intensely cold in Greenland as in Norway. Now, it is unquestionable that very fine corn grows in Norway; and what I shall say on this subject may appear strange to you, but persons whose opinions may be depended on have certified it to me. There are places in Norway where they have double harvests in three months, for the reasons which you shall now hear. These places are plains opposite rocks, upon which the sun strikes continually during the glowing heats of the months of June, July, and August; and so intense a heat is reflected from the rocks upon these plains, that in the course of six weeks they plough, sow, and gather in the ripe corn. And as these lands are very fat and moist, from the quantity of melted snow with which they have been watered, and which the sun has hardened, they begin to sow again, and at the end of another six weeks they do not fail to reap a second harvest as good as the first.

It is probable that the land of Greenland, like all other lands, is both good and bad in different parts, that it has both plains and mountains, some fertile and others barren. It is certain that there are a great number of rocks, and the Icelandic Chronicle says especially that marbles of all colours are found there. It is agreed that the grass of the pasturage is excellent, and that there are great quantities of sheep and oxen, as well as of hares, horses, stags, reindecr, wolves, lynxes, foxes, and bears in great numbers, both white and black. The Icelandic Chronicle also states that beavers have been canght there, and martens as fine as the sables of Muscovy. A great number of white and grey falcons are found there, more than in any other part of the world. Formerly they used to take these birds, as a great rarity and on account of their extreme value, to the king of Denmark, who made presents of them to lings and princes, their 
neighbours and friends; for hawking is not at all practised in Denmark any more than in the other parts of the north.

The sea round Greenland abounds in fish ; it is full of seawolves, seals, and walruses, and contains an incredible number of whales. I do not know whether I ought to class the great white bear of Greenland with the land or water animals; for, whilst the black bear remains on the land and lives only upon flesh, the white bear remains in the sea and only lives upon fish: they are much larger and more savage than the black. They go in quest of sea-molves and scals, who gire birth to their young upon the ice for fear of the whales. 'They are very cager for young whales, and find them daintier food than other fish. They do not go willingly into the open sea when the ice is melted, not because they do not swim and cannot live in the water as fish, but from a natural antipathy they fear the whales, who seent and pursue them to derour their young. This is why, when the ice becomes detached from North Greenland and is carried southward, the white bears who are upon it dare not leave it, and by the time they are landed in either Iceland or Norway, wherever the ice carries them, they become furious with hunger.

Heu male tum solis Norregûm erratur in oris.

Strange storics are told of the ravages these animals have made in these countries. Greenland has always been very productive in horn, which they call unicorn-horn. In Denmark many are secn whole, and an infinite number of ends and pieces, so that they are very common in this kingdom. You will ask me what animals these are that have these horns. I must tell you, Sir, that these horns, improperly so called, hare nothing in common with real horn, rightly so called, of any kind whatever. And as the name of the horns is doubtful, there are those who also doubt whether the animals who bear them are flesh or fish. You will 
observe that the unicorn-horn which we saw in Denmark, whether whole or in pieces, is of the same composition, the same form, and has the same properties as those which are seen in France and other parts. That beautiful entire horn of which I once spoke to you, and which I saw at Frederiksburg in the possession of the king of Denmark, is decidedly larger than that of St. Denis. It is true that it is not straight, but bent at two or three feet from the point; but as for the rest, it is of the same colour, shape, and weight as that at St. Denis. As for the pieces of horn which we saw in different places in Copenhagen, it is a fact that they were regarded as antidotes against poison, the same as those are which are seen in Paris or elsewhere. It bcing taken for granted that all the kinds of horn which are scen in Denmark are exactly like those of France, and that those of Denmark come from Greenland, the question arises, what are these animals which bcar these horns in Greenland? M. Vormius first told me that they were fish; upon which I must tell you that I had great disputes with him when we were at Christianople, because it overturns the opinion of all the ancient naturalists who have treated of unicorns, and who have described them to us as land animals, and with four feet; and that it clashes with several passages of holy scripture, which can only be understood as having reference to unicorns with four feet. The good M. Tormius, accurate and learned in the curiositics of the north, wrote me this account from Copenhagen, which I will give you from his letter. "Some years since," says he, "I was staying with M. Fris, high chancellor of Denmark, predecessor of M. Thomassen, the present chancellor. I complained to this great man, who all his life was an ornament and support to his country, of the little curiosity our merchants and sailor's had who visited Greenland, not to have ascertained what the animals are that bear the horn they bring in such abundance, and not to have taken a piece of their flesh or of their skin by which to gain some informa- 
tion. 'They have more curiosity than you think,' answered the clancellor; and he immediately sent for a large dried skull, to which was attached a stump of this kind of horn four feet long. I was delighted to hold in my hand so rare and precious a thing, and could not look at it enough, for at first it was out of my power to comprehend what it was. I begged the chancellor to allow me to take it home and consider it more at my leisure, which he willingly permitted me to do. I found that this skull bore a correct resemblance to that of a whale, that it had two holes at the top, and that these holes pierced the palate. 'These were doubtless the two apertures through which the animal threw out the water that it drank. And I may remark, that what they call its horn, was fixed to the left part of the upper jaw. I invited my most intelligent friends and the best scholars of my audience, to come and see this rarity in my cabinet. A painter whom I had sent for came, and, in the presence of the assistants, made a drawing of this skull, with the horn just as it was both in shape and size, in order that they might be witnesses that my copy had been taken from a true original. My curiosity did not stop there: having heard that a similar animal had been taken and caught in Iceland, I wrote to the bishop of Hole, named 'Thorlac Scalonins, who was formerly my pupil at Copenhagen, and begged lim, as my friend, to send me the picture of this animal. This he did, at the same time telling me that the Icelanders called it narhual, signifying a whale which feeds on carcases; because hual means a whale, and $n a r$, a dead body. It was indeed the portrait of a genuine fish which resembled a whale, and you have my promise to show it you when you return from Christianople, together with that of the skull that I had from the chancellor Fris."

M. Vormius did not fail, on our return, to fulfil his promise; and, more than that, was not satisfied that I should sce merely the pictures of the fish, but he took me into his cabinet, where I saw upon a table the original skull, with the 
horn of the animal which M. chancellor Fris had lent him. He had had it on the faith of his promise from a gentleman of Denmark, son-in-law to M. Fris, to whose portion it fell, and who valued it at eight thousand rix-dollars. He had sent for it from a distance of twenty leagues from Copenhagen, in order to show it to the ambassador. I confess I could not leave off admiring so exquisite a curiosity, and having brought it to the ambassador, His Excellency examined it with great interest, and begged M. Vormius to lend it him in order that he might have an exact painting made of it; which he dicl, and took to Paris. 'This great man, who is always ready to show every kindness and attention to connoisseurs, will be delighted to show this picture, and to exhibit all the most curious things that he will carry with him from the north. He has a particular regard for you, sir, and to all the gentlemen who compose the illustrious Mercuriale of the library of M. Bourdelot. I know that his cabinet, which he is anxious to complete, if God grant him to arrive safe in France, will be thrown open with great pleasure to you and all these gentlemen.

It is certain that the name of unicorn is equivocal, and that it belongs to many kinds of animals, such as the onix and the Indian ass, which Aristotle mentions, and the ferocious beast described by Pliny, which has the head of a stag, the body of a horsc, and a solid foot like that of an elephant, with incomparable swiftness and strength. It is, in fact, the same unicorn of which the holy scripture speaks in many places; so agile, that it is written as a marvel and wonder, that God would cause Scirion, a mountain in Lebanon, "to leap like a young unicorn"; and so strong, that the strength of God himself is compared to it. "Deus fortis," said Moses, "Eductor Judæorum, vires ejus ut monocerotis." Now there is no reason for classing our northern unicorns, which we know to be aquatic, with that species of unicorn which is belicved to be in the south or the east, and which we well know to be a 
land animal. The prophet Isaiah, foretelling that God would drive out the Jews from Jerusalem, speaks of their kings as unicorns. "Descendent," says he, "Unicornes cum cis," which could only have had reference to a terrestrial descent, and if the prophet had believed the muicorns to be fishes, he would have rather said "natabunt" instead of "descendent".

I shall lay down, thereforc, a species of sea unicorn in the same manner as there have becn laid down species of sea dogs, sca calves, and sea wolves; and this will be no novelty, as Bartolin, a Danish author, in his treatise on unicorns, has written a chapter expressly on sea unicorns. There arises, however, a difficulty in opposition to this mode of classification, for it is a question whether the sca unicorns of which wo are herc speaking are really unicorns, and whether what wo call their horns are really horns or tecth. The solution of the first doubt depends on that of the sccond; for, if they are teeth, these fish cannot be called unicorns, because they would have no horns; if, on the other hand, they are horns, they would evidently be unicorns, because they would have only one horn. M. Vormius affirms that they are teeth and not horns, and I sec that Angrimus Jonas calls them tecth, in that part of his "Specimen Islandicum" where he speaks of a remarkable shipwreck that befcl a bishop of Greenland, named Arnaud, on his way to Norway, whose vesscl was dashed in pieces by a storm within the isthmus of Western Iceland. This shipwreck happened A.D. 1126. In the survey that was taken of the things saved from the wreck, "Reperti sunt," says the good Angrimus, "dentes balcnarum, pretiosi, ct potiores, maris estu in siccum rejecti, ac literis Runicis, indelcbili glutine rubescentis coloris, inscripti, vt Nautarum quilibet suos, peracta aliquando navigatione, recognosccret."

Now it is certain that what Angrimus Jonas here calls "Dentes balenarum pretiosos", is understood in Denmark, and ought to be understood of these horns, which we call 
unicorn's, and of which we are now speaking. What makes me think they are teeth and not horns, is, that Aristotle tells us for true and certain, that all unicorns had their horns in the middle of their forehead, in the usual place where horns grow; whilst these fish have what we call a horn at the end of their jaw and gum, at the place where teeth usually grow. Horns are fastened on the forehead by symphysis, while tecth go deep into the jaw by gomphosis; and we saw clearly in the skull which M. Vormius showed us, that what we had taken for a horn, was buried in the jaw about a foot deep, and that it extended outwards like a lance in rest, just in the same manner as the fish pristes carries its saw, and the other fish xiphias its sword.

I have read a fine argument in Aristotle, or rather, I should call it, an excellent remark, upon the single hornedness of unicorns: he says, that all animals which have two horns have the hoof divided into two, and that all unicorns have the nail undivided and solid; that nature has made the same union and consoliclation of hoofs and horns at the feet and head of unicorns, as it has made a similar division of hoofs and horns at the feet and head of other animals. From which it results, that the only distinction between the unicorn and other animals, consists in the unity and solidity of their hoofs and horns; and by the same rule that unicorns have their hoofs similarly placed with those of other animals, they have their horns in the same place in the head, namely, the forehead. Again, as other animals which have two horns, have them onc on either side of the forehead, unicorns, which have only one, have it in the midlle of the forehead. But, in the same manner as the fish of which we are speaking, having neither hoofs nor feet, cannot have horns in the head; so it follows that the so-called horns, bcing buried in their jaw and not fixed in their forehead, cannot be horns, and therefore must be teeth.

This was not my opinion at the first, but whilst I was dis- 
puting the point with M. Vormius, M. le Grand Maitre of Denmark, of whose high birth, eminent virtuc, and exalted dignity in Denmark (that of the person next in absolute power after the king) you have heard in my letters,-this great man, who has honoured me with particular marks of his goodwill, and who took great pleasure in satisfying my curiosity as far as it was possible to do so, told me a circumstance relating to this subject, which confirmed me in my first opinion that they were horns and not teeth: he said, that the king of Denmark his master, wishing to make a present of a piece of this sort of horn, and wishing it to be particularly beautiful, directed hin to saw an entire horn which he had at the stump of the root, where it is thickest and finest. Having sawn one part of the horn, which he thought was solid, he came to a cavity, and was astonished to find within a small horn, of the same shape and composition as the large one. He continued cutting the large one all round without touching the small one, and found the little horn, as well as the cavity inside the larger horn, extended a foot in length; the rest of the large horn being solid. On hearing this, I formed the idea that the animals which have these horns change them like stags, and that their large horns fall off and others grow in their place. I thought that this was, without doubt, the reason that so many horns detached from the head were brought by the floating ice of Greenland to Iceland; but when I saw the skull of which I have spoken to you, and had duly exanined the long root which was fixed in the jaw, I could not help changing my opinion. Even what M. le Grand Maître told me, made me suppose that it was a tooth and not a horn that he had sawn. It may be that these teeth fall and are renewed in the case of these fish, as they are in the case of children, and sometimes of men; and we often see that these teeth which fall are pushed out and made to fall by other new tecth, which come before the old have gone. A similar cireumstance could not happen 
to stags which cast their horns; their heads remain bare as though they never had horns, until the new ones begin to grow again and to take shape.

But as so long a discourse about horns may be very wearisome, I shall terminate it with the conclusion we must come to respecting the horn, called a unicorn's, which is at St. Denis. I have said that it is in all respects perfectly similar to those of Denmark. 'To this I shall add, that the Danes consider it a ccrtain fact, and engage to prove it, that all those specics of horn which are seen in Muscovy, Germany, Italy, and France come from Denmark, where this kind of traffic was much in vogue when the passage from Norway to Grecnland was free and known, and when regular passages were made from one to the other every year. The Danes, who sent them to different parts for sale, did not care to say that they were the teeth of fish, but stated that they were the horns of the unicorns, wishing by that means to sell them at a ligher price. Having done this formerly, they continue to do it still. It is not long since the New Greenland Company at Copenhagen sent one of their partners to Muscovy with several large pieces of this kind of horn, and among others one of very considerable size, to sell to the Grand Duke of Muscory. It is said that the Grand Duke thought it very fine, and had it examined by his physician. He knowing more about it than the others, told the Grand Duke that it was the tooth of a fish, and the envoy returned to Copenhagen without selling anything. When he gave an account of his voyage to his partners, he threw all the blame of his misfortune on the wickedness of the physician, who had depreciated his merchandise by saying that all that he had brought was only the teeth of fish. "You managed badly," replied one of his partners, who afterwards told mo the story. "Why did you not give two or three hundred ducats to this physician, to persuade him that they were from unicorns?" You may therefore be quite sure that the 
horn at St. Denis came originally from the same place, and was sold in this manner. I am afraid to say how long it is since I have scen it; but if I am not mistaken in the faint recollection I still have of it, it is a tooth like those we saw in Demmark, for it has the same root as the other's. Its root is hollow and decayed at the end, like a bad tooth. If this be the case, I maintain that it is a tooth, which has fallen naturally from the jaw of the fish which the Icelanders call narhual, and that it is not a horn.

To return to Greenland. The Icelandic Chronicle states, that the air there is softer and more temperate than in Norway, that it snows less, and that the cold is not so severe. 'This does not mean that it does not sometimes freeze very hard, and that there are not very violent storms; but that serere cold and those tremendous storms happen very seldom and do not last long. The Danish Chronicle remarks as a strange thing, that in the year 1308 fearful elaps of thunder were heard in Greenland, and that fire from heaven fell upon a church called Skalholt, which was entirely burnt; and that after the thunder and fire there arose a severe tempest, which hurled down the tops of several rocks, and ashes flew out from these broken rocks in such abundance, that they thought God had sent them to punish the people of the country. 'This tempest was followed by so severe a winter', that there was never known one to equal it in Greenland, and the ice remained for a whole year without melting. When I related the wonder of this shower of ashes to the ambassador, he told me that, being at La Rochelle, a sea captain who had returned from the Canaries assured hin, while they were at anchor six leagues from these islands, there was a similar shower of ashes fell on the roads where they were lying, and that his vessel was covered with them just as though snow had fallen on it; that this terrific storm was caused by an earthquake, which shook some volcanos which are in the Canaries, and the wind had thrown the 
cinders from them into the sea to a distance of six leagues. There is a probability that the ashes which came from these rocks in Greenland proceeded from a like cause, and that there are in this country burning mountains and subterraneous fires, as in the Canaries and elsewhere. Doubtless this may be the case, and is not inconsistent, judging from the example, and, indeed, the proximity of Mount Hecla in Iceland, which is much more to the north than that part of Greenland, as also from the instances of other volcanoes which are in the higher parts of Lapland and very far beyond the Arctic circle. The idea is confirmed also by what we have remarked before in the old description of this land: that there are baths there, so hot that they camnot be borne even in winter.

'The summer of Greenland is always fine, day and night, if the perpetual twilight which lasts the whole night in the summer may be so called. As the days are very short in winter, the nights, by way of compensation, are very long; and nature then produces such a wouder, that I should not have dared to write it to you had it not been mentioned by the Icelandic Chronicle as a miracle, and if I had not entire confidence in M. Rets, who read it to me and faithfully explained it. 'There rises in Greenland a light with the night when the moon is new, or on the point of becoming so, which lights up all the country as if the moon were full, and the darker the night the brighter this light shines. It takes its course on the north coast, on account of which it is ealled the Northern Light. It looks like flying fire, and stretches up into the sky like a high and long palisade. It passes from one place to another, and leaves smoke in the places it leaves. None but those who have seen it could give any idea of the quickness and agility of its morements; it lasts all night and disappears at sumrise. I leave it to those learned men who are better versed than $I$ in natural philosophy to discover the cause of this meteor, and whether there arises any vapour from the 
ground, which may become heated and ignited by its own movement, the rapidity of which may resemble that of those long rockets or tongues of fire, which fall through or across the air, or of the lights which flutter about churchyards. I was assured that this northern light was scen distinetly from Iecland and Norway, when the sky was calm and the night was not troubled with any clouds. It not only lights the people of the Arctic World, it cren extends as far as our own climates. And this light is doubtless the same that our well-known friend, the learned and judicious philosopher Monsieur Gassendy, told me he had observed several times, and to which he gave the name of Amrora Borealis. The most remarkable he had ever seen was that which appeared to all France, silente lumâ (for it was only one day old), during the night of the twelfth and thirteenth of September 1621. He has given a summary of it in the life of M. Peresc, but it is fully and wonderfully well described in the learned observations made by him at the close of his Exercitation against Dr. Flud. To this I must refer you, not wishing to engage myself still more deeply in this subject, but to take up the thread again of my history of Greenland.

The Danish Chronicle states, that in the year 1271, a strong wind from the north-west carried to Iceland so large a quantity of ice, laden with such a number of bears and so much wood, that they thought what they had discovered at the west of Greenland was not the whole of Greenland, and that this land extended farther north-west. This induced some Icelandic sailors to attempt this discovery : they found, however, nothing but ice. The kings of Norway and Denmark had for a long time entertained the same idea and the same design, and had sent there many vessels, and even had gone themselves, but without any better success than the Icelandic sailors. Probably the sailors were induced to make the trial, cither from report, or from the opinion receired and founded on some report that there were in that comtry several mines 
of gold, silver, and precious stones; or perhaps this passage in Job made some impression on their mind: "Aurum ab aquilone venit." I will mention what the same chronicle relates on this subject. It states that some time ago merchants returned from this royage with vast treasures; and it says also that in the time of St. Olaus, king of Norway, the mariners of Friesland undertook the same voyage with the same result, and they were overtaken by a violent storm, which cast them on the rocks of this coast, and they were obliged to take refuge in certain insecure ports. It adds, that having hazarded a descent, they saw rather near the shore some miserable looking huts hollowed out in the ground, and around these cabins heaps of iron ore, in which a quantity of gold and silver was shining; this tempted them to go and take some of it. And each took as much of it as he could carry away. But as they returned to their vessels, they saw coming out from these covered holes deformed men as hideous as devils, with bows and slings and large dogs following them. The terror that seized these sailors obliged them to double their speed, that they might save themselves and their burdens: but unfortunately one idler amongst them fell into the hands of these savages, who tore him in pieces in a moment before his companions' eyes. The Danish Chronicle goes on to say, that the country is full of riches, from which the account has arisen that Saturn hid his treasures there, and that it is only inhabited by devils.

There is a chapter in the Icclandic Chronicle entitled, Road and Passage from Norway to Greenland. The text runs thus. The true route to Grecnland, according to what the well-informed pilots tell us who were born in Greenland or have come from thence a short time since, is this: From Nordstaten Sundmur in Norway, bcaring straight torards the west as far as Horensunt on the eastern coast of Iceland, the navigation is scven days. From Suofucls Jokel, which is a sulphur mountain in Iccland, to Grecnland, the shortest 
navigation is towards the west. Halfway between Grecnland and Iceland is Gundebiurne Slieer : such was formerly the route before the ice came from the north and rendered this narigation perilous. It then writes, but in a scparate article, that northwards from Languenes, the most northern cxtremity of Iceland, there are eightecn leagues to Ostrehorn, which means eastern liorn. From Ostrehorn to Truallsbredde the voyage takes two days and nights.

I do not pretend to say that any one undertakes the voyage to Grecnland by this route, but all that I could understand is, that the navigation of this sea has always becn difficult and perilous. You may have noticed the same thing from what I told you of the return of Lciffe into Greenland to his father, Eric the Red, and from the shipwreck which befel the bishop Arnaud, and from what I have just told you of the mariners of Grecnland.

There is also in the same Icelandic Chronicle a chapter headed, Transcribed from an old book, ontitled, Speculum Regale, touching the affuirs of Gremland. The text of it is much more clear than that of the former. Some time ago, it states, there were secn in the sca of Greenland three sea monsters, of cnormons size. The first, which the Norwcgians saw from the waist upwards out of the water, they called haffstramb : it was like a man about the neck, head, face, nose, and mouth, with the exception of the head being very much elcrated and pointed towards the top. Its shoulders were broad, and at their extromity were two stumps of arms without hands. The body was slender below, but they have never been able to see its form lower than the waist. Its look was chilling. There were heavy storms each time that this phantom appcared on the water. The second monster has becn called marguguer. It was formed down to the waist like a woman. It had large breasts, dishevelled hair, and huge hands at the end of the stumps of the arms, with long fingers, webbed like the fect 
of a duck. It was seen holding fish in its hand and eating them: this phantom always preceded some terrible storm. If it plunges in the water with its face towards the sailors it is a sign they will not be shipwrecked, but if it turns its back to them they are lost. The third monster has been called hafgierdingucr, which was not, properly speaking, a monster, but three large heads or mountains of water which the tempest brought up; and when the vessels unfortunately find themselves surrounded by the triangle formed by these mountains they nearly all perish, and few escape. This so-called monster was engendered by the sea currents and contrary and impetuous winds, which overtake vessels and swallow them up.

This book states, also, that in this sea there are large masses of ice standing up like statues, of singular shape. It adrises those who wish to go to Greenland to go towards the south-west before landing in the country, on account of the quantity of ice which on this sca floats much before it, even in the summer. It advises, also, those who are in any peril in this ice, to do what others have done in similar encounters, which is, to put their sloops on the thickest part of this ice, with as much food as they have, and to wait there until the ice carries them to land; or, supposing it begins to melt, to try and save themselves in their sloops.

Here finishes the history of ancient Grecnland; and the history of Denmark quotes prccisely the year 1348, in which a terrible pestilence, called the black pestilence, carried off' a great part of the people of the north. It killed the principal sailors and merchants in Norway and Denmark, who composed the companies of Greenland in the two kingdoms. It has also becn remarked, that from this time the royages and commerce with Greenland were interrupted and began to fall off. However, M. Vormius assures me, that he read in an old Danish manuscript, that about the year of grace 1484, in the reign of king John, there still were in the town 
of Bergen, in Norway, more than forty sailors, who went every year into Grecnland, bringing back costly merchandise ; that, not being willing to sell that year to some German merchants who had gone to Bergen to buy, these Germans did not say anything, but invited the sailors to supper and killed them all in one night. The account has little appearance of truth, from the manner in which it is written ; for it is not likely that at that time they went so freely from Norway to Greenland. This is altogether at variance with the narration which I am about to give you, and which is unquestionable, of the fall and entire ruin of the commerce which Norway and Dennark had with Greenland.

Jou will be aware, sir, that the tributes of Greenland were anciently destined and employed for the table of the kings of Norway, and that no sailor dare go to Greenland without leave, at the peril of his life. It happened that in the year 1389, during the time that Henry, bishop of Garde, was in Denmark assisting in the states of the kingdom which were in Funen, in the reign of Queen Margaret, who had united the two crowns of Norway and Denmark, that the merchants of Norway, who were gone to Greenland without leave, were accused of having taken the taxes which were due to the table of the queen. The queen dealt very severely with these merchants, and they would have been hanged but for an oath which they took upon the Bible, that they had not gone to Greenland intentionally, but had been carried there by a tempest; and that they had brought nothing away but some purehased merehandise; neither had they in any way meddled with the tributes of the queen. ITpon this oath they were released, but the danger they had escaped, and the severe prohibitions given out against their going to Greenland without leave, so intimidated the others, that from that time neither merchants nor sailor's clared to hazard it. 'T'he queen some time after sent some ships which were never secn again, and it was known that they hat perished, by the 
very fact that they never could learn where nor how they did perish. The old Norwegian sailors were so terrified at these accounts, that they dare not return on this sea. The queen, who was engaged in wars with Sweden, did not press them, and thought no more of Girecnland.

The Danish Chronicle, which gave me this information, states, that about the year of grace 1406, the bishop Eskild, of Drontheim, wishing to have the same care of Greenland that his predecessors had had, sent them a bishop named Andrew, to succeed Henry, bishop of Garde, in case he were dead, or to bring news of him if he were alive; but from the time that Andrew went on board his vessel and had set sail, nothing more was heard of him ; and notwithstanding the great exertion made, it was impossible to discover what had become of him or of the bishop Henry. This was the last bishop sent from Greenland; the same chronicle enumerates all the kings of Denmark, from queen Margaret to king Christian IV now reigning, to show, either the little progress that the one made in Greenland, or the desire others had to find this land again. And it is also important, sir, that you should be informed of this succession of fatalities and misfortunes which have made us lose sight of a celebrated country, which was formerly known, inhabited, and frequented by people of our own world.

King Eric, of Pomerania, succeeded queen Margaret, and being a foreign king and having just come to Denmark, he clid not even make himself aware of the fact that there was such a country in the world as Greenland. Christopher of Bavaria, who succeeded Eric, employed all his reign in making war on the Vandals, who are Pomeranians. The family of Oldenbourg, which now reigns in Denmark, began to reign in the year of grace 1448. The king Christian, the first of his name and line, instead of turning his attention to the north turned it to the soutl, made a pilgrimage to Rome, obtained from the Pope the 
country of Dittmarsen for the crown of Demmark, and permission to establish an academy at Copenhagen. Christian II sueceded Christian I, and solemnly promised when he was made king to do all in his power to recover Greenland. But so far from regaining the land that his predecessors had lost, he was obliged to give up even the states which he possessed. His cruelties caused him to be driven from Sweden, which queen Margaret had united to the two crowns of Norway and Denmark, so that the three only made one. He retired to Demmark under the influence of the same furious spirit which had possessed him in Sweden, and the Danes, who were no more able to endure him than the Swedes, deprived him of the kingdom; in consequence of which he is represented among the kings of Denmark with a broken sceptre in his hand. His chancellor, Eric Valkandor, a Danish gentleman of great virtue and talent, was created, after the disgrace of his master, archbishop of Drontheim. He retired to his archbishopric, and then he gave his attention to the plan of making another search for Greenland, and the means of reaching that country. He read all the books which spoke of it, questioned all the merchants and sailors of Norway who knew anything about it, and drew up a map of the route it would be necessary to take. But in 1524, as he was about to execute this design, a nobleman of Norway quarrelled with him, and made him quit both the archbishopric and the kingdom. He took refuge at Rome, and there died. Frederick I, Christian's uncle, had now taken possession of the kingdoms of Denmark and Norway; and as the faction of Christian was not yet cxtinguished, Frederick, who suspected and feared Valkandor, banished him from Norway, and dispersed the companies he had formed for the discovery of Greenland. Christian III succeeded Frederick I. He had the passage to Greenland tried, but those whom he sent there were not able to discover it. 'This compelled the king to repeal the laws which the kings, his pre- 
decessors, had levied, that no one should go to Greenland withont leave. He allowed any one who wished to go without requiring his special permission; but the Norwegians had so few sailors, and so poor also were they, that they had not the means to make preparations for a voyage attended with such difficulty and danger.

King Frederick II followed out the wish of his father, Christian III, and sent out a man named Magnus Heigningsen to the discovery of Greenland. And if it is as the chronicle states, there is an unknown secret and a hidden cause, which visibly oppose the designs that may be formed for gaining a knowledge of this land. Magnus Heigningsen, after many errors and mishaps, discovered Greenland; but was not able to get near it, because, before he had seen the land, his ship stopped short: at which he was mnch astonished, and with reason; for it was in the open sea and in great depth of water, there was no ice, and the wind was fresh. Unable to proceed he was obliged to return to Denmark, where he reported what had happened to him, and told the king that there were loadstones at the bottom of the sea which arrested his vessel. If he had known the history of the Remora, perhaps he would have given that also as a reason as well as the loadstone. This adventure occurred in the year 1588, in the reign of Fredcrick II ; and our Danish Chronicle, which is comected with the chain of events, has inserted between the reigns of Christian and Frederick, a long account of a voyage that Martin Frobisher, an English captain, made to Greenland in 1577. This narration throws much more light on Greenland and the people than the history we have used thus far; therefore I have thought proper to send you a version of what is there said.

Martin Frobisher left England for Greenland in 15\%7, as I have already said. He discovered it, but could not land that year on account of the night and the ice; for winter had surprised them on their voyage. Ilaving returned to Lng- 
land and reported what he had seen to queen Elizabeth, she thought, from the accounts, that she had gained that unknown land. Accordingly the following spring she gave Frobisher three ressels, with which he set out, and having found the country, landed on the east coast. 'The inhabitants of the part where he landed took to flight on seeing the English, and left their houses to conceal themselves whererer they could. Some chimbed to the tops of the highest rocks, whence they threw themselves over into the sea. The English, who could not tame these savages, entered the houses which they had abandoned. These were, properly speaking, tents, made of the skins of sea-calves or whales, stretched upon four large poles clererly stitched with sinews. 'They noticed that all these tents had two doors, one on the west, the other on the south side, and were so placed as to shelter them from the most severe winds-the east and the north. They found there only a hideous old woman, and a young woman enceinte, with a child, whom she was holding by the hand. They took them away with them. They took them by force from the old woman, who howled horribly. On leaving, they coasted along the eastern side, and saw a monster in the water about the size of an ox, which had at the end of the muzzle a horn, an ell and a half in length, which they thought was an unicorn. They sailed from thence towards the north-east, and discorered a land of so pleasant an aspect that they were persuaded to go on shore; and as this was in the continent of Greenland they called it Anauarich, in order to distinguish it by another name. They found that this country was subject to carthquakes, which overturned large rocks into the plains, and while they lasted were very dangerous. They remained there some time, as they found some gravel pits, where there was a plentiful supply of gold, with which they filled three hundred casks. They did all in their power to tame the sarages of the country, who appeared to be willing to become friends. They answered by signs to those of 
the English, and gave them to understand that if they went higher up they would find what they wanted. Frobisher told them he would go there, and getting into a sloop with some soldiers, he gave orders to his three vessels to follow. Coasting along the shore higher up he perceived a number of sarages on the rocks, and began to fear he might be surprised by them. The savages who conducted him over the coast understood the alarm he felt, and, in order not to frighten him away, made three men appear from under the dyke, much better made and better clothed than the others, who invited them by signs and demonstrations of friendship to land. Frobisher went to them full of confidence, as he only saw three men in the port, and the sarages on the rock were at some distance from them. But those who were hidden under the dyke, as soon as they saw Frobisher, became impatient, and rushed in a crowd to the port. This made Frobisher draw back, but, nevertheless, the savages were not discouraged; they still tried to attract the English, and threw quantities of raw flesh on the shore, as if they had to do with bulldogs. When the English did not seem inclined to approach, the savages had recourse to another stratagem. They brought a man who was lame, or at least appeared to be so, to the sea shore, and having left him there did not show themselves for some time, as though they had gone array to a distanee from them. Their idea was that the English, after the custom of strangers, would come to take away this poor wretch, who could not save himself, to serve them as interpreter. But the English, suspecting the deceit, fired at the lame man, who sprang up in consternation and ran back at full speed to the land. Upon this an immense number of savages appeared at the sides of the dyke, and showered upon the English a prodigious quantity of stones and arrows from slings and bows; at which the English only laughed, and in their turn fired muskets and cannon, which frightened them away in a moment. 
'The history says that these sarages are of a cleceitful and ferocious disposition, and that they cannot be tamed, either by presents or kindness. 'They are fat but active, and their skins are of an olive colour; it is believed that there are blacks among them like Ethiopians. 'They are dressed in seal-skins, sewn together with sinews. 'Their women wear their hair in disorder, and turn it behind their ears to show their faces, which are painted blue and yellow. They do not, like our women, wear petticoats, but several pairs of drawers made of the skins of fish, which they put on one over the other. Each pair has pockets, which they fill with knives, thread, needles, little looking-glasses, and other trifles which foreigners bring them, or that the sea throws up from the shipwrecks of foreigners who attempt their shores. The shirts of the men and chemises of the women are made of the intestines of fish, sewn with very fine sinews. Their clothes are large, and they bind them with straps of prepared skin. 'They are very dirty and filthy. Their tongue serves them for napkin and handkerchief, and they have no modesty abont things other men are ashamed of. Those who have a great many bows, slings, boats, and skulls, are considered rich men : their bows are short and their arrows thin, armed at the end with bone or sharpened horn. They are skilful in drawing the bow and using the sling, as also in throwing the javelin at fish in the water. Their little boats are corered with seal-skin, and hold only one man. Their large boats are made of pieces of wood joined one to the other by cross beams, and covered with the skin of whales sewn with large sinews. The largest of these hold twenty men; their sails, like their shirts, are made of intestines of fish, sewn with fine sinews. And although there is no iron in these boats, they are fastened with so much skill and strength that they make easy way in the open sea, and are not injured even by heary storms. They have nothing of a reptile or venomous nature in their country, with the ex- 
ception of spiclers. 'There are a great number of gnats that sting very sharply, and the sting is followed by large swellings on the face. They have no soft water, but such as they get from the melting snow. The chronicle states, that the colrl which seizes the ground stops the passage of the sources. They have very large dogs, which they attach to their sledges and use as we do horses.

Here this account enck, and I do not know whether the Danish Chronicler has taken it from the English history of Martin Frobisher, or whether he has written it from any legend that he may have heard, as the ancient Danes used to do, who composed the histories of their times in ballads.

To return to the kings of Denmark. Christian IV, now reigning, son of Frederick II, took the subject of Greenland very much to heart, and resolved to discover it, although his father and grandfather had in vain attempted to do so. For the accomplishment of this design he sent for a captain and a clever pilot from England, who had the reputation of knowing this sea very well, and of being well acquainted with the whole of this routs. Being provided with this pilot, he fitted out three vessels under the conduct of Gotske Iindenau, a Danish gentleman, their admiral. They left the Sound in the early part of the summer of the year 1605 . The threc vessels sailed together for some time, but as the English captain had gained the height he desired, he took the route of south-west for fear of the ice, so that he might be able the more easily to land in Greenland. The route he took corresponded with the old Icelandic route which I have instanced to you, which recommends the same mode of proceeding. The Danish admiral, thinking that the English eaptain should not have taken this south-west route, continued his own towards the north-east, and arrived alone on his side in Greenland. No sooner had he cast anchor than a number of savages, who had discovered him from the top of the shore where they were, jumped into their 
little boats and eame to sec him in his resscl. He reccived them with joy, and gave them some good wine to drink; but they seemed to think it sour, for they made grimaces while drinking it. 'They saw some whate oil, which they asked for, and the Danes gave them lunge pots of it, which they swallowed with pleasure and avidity. 'The sarages had brought skins of dogs, bears, and scals, and a great number of horns, which the chronicle states were valuable, in pieces, cnds, and stumps; these they exchanged for needles, knives, looking-glasses, elasps, and such trifles of similar value that the Danes happened to display. 'They laughed at the gold and silver money which was offered to them, and appeared very eager for any articles made of steel ; for they like them above everything, and would give, in order to obtain them, whatever they most prized, their bows, arrows, boats, and oars; and when they have nothing more to give they stripped themselves and gave their shirts.

Gotske Lindenau remained three days at this port, and the chronicle does not say that he once set foot on the land. IIC doubtless did not dare to hazard a descent, or expose the small number of his people to the countless multitude of savages which this comntry contained. He weighed anchor and left on the fourth day, but before going he retained two men in his ressels, who made so many efforts to free themsclves from the hands of the Danes and to jump into the sea, that they found it necessary to bind them. Those who had landed, seeing their companions bound and being earried away, uttered horrible cries and threw a quantity of stones and arrows at the Danes, who fired off the camnon and frightened them away. The admiral returned alone to Denmark, as he had arrived alone at the place where he had landed.

The English captain, followed by the other Danish vessels, entered Greenland, so states the chronicler, at the point of land that stands ont westward. 'This heatland can only 
be Cape Farewell. It is also certain that he went into Davis' Gulf, and coasted the land on the cast of this gulf. He discovered a number of good harbours, a beautiful country, and large verdant plains. The savages of this country bartered with him, in the same manner as the savages of the other did with Gotske Lindenau. They were much more timid and mistrustful than the others, for they had no sooner received their exchange from the Danes, than they fled to their boats as if they had robbed them and were being pursued. The Danes were anxious to land in some of their ports, and armed themselves for this purpose. The country appeared pretty good when they landed, but sandy and stony like that of Norway. They judged by the smoke from the ground that there were sulphur pits, and found a great many pieces of silver ore, which they took to Denmark, and from one hundredweight of ore they extracted twenty-six ounces of silver. The English captain, when he found so many fine ports all along the coast, gave them Danish names, and before leaving made a map of them. He also took four savages, of better mien than those which the Danes had been able to take; and onc of these four was so enraged at being taken, that the Danes, finding they could not secure him, beat him with the butt-end of the muskets, which so intimidated the others that they followed willingly. At the same time the savages formed themselves into a band to revenge the death of the one and to recover the others. They cut off the passage of the Danes from the sea in order to engage them in combat in the harbour, and to prevent their embarking; but the Danes discharged their muskets, and the vessels fired camnon, with such effect that the savages, astonished at the noise and the fire, fled on all sides and left the passage free to the Danes. The latter went back to their vessels, weighed anchor, and returned to Denmark with the three savages, whom they presented to the king their master, who found them much better made and more 
civilized than the two that Gotske Lindenau had brought: of different clothes, language, and manners.

'The ling of Denmark, satisfied with this first royage, resolved upon a second, and sent the following year, 1606, the same Gotske Lindenau with five good vessels to Greenland. 'This admiral left the Sound on the Sth of May, and took with him the three savages whom the English Captain had taken in Davis Gulf, to show him the way and to act as interpreters. 'The poor ereatures manifested unspeakable joy at their return to their country: but one of them died of illness out at sea, and was thrown overboard. Gotske Lindenau took the same American route that the English captain had taken, namely, that of the south-west and Davis' Gulf by Cape Farewell. One of the five vessels lost her way in the fogs, and the four arrived in Greenland on the 3rd of August. At the first roadstead where the Danes cast anchor the savages appeared in great number's on the shore, but would not traffic; and as they seemed to mistrust the Danes, so the Danes would not trust them. They were compelled therefore to change their position and to go higher up, where they found a harbour still finer than the first; but the savages were of as bad a description as the others, for they looked at the Danes with suspicion, as if they were inclined to attack them if they attempted to land. The Danes, who were no more inclined to put confidence in these than in the others, did not hazard a descent, but went still higher, and as they coasted along the savages kept pace, with their little boats. 'The Danes surprised at different times six of these savages, with their boats and the small stores that were in them, and carried them. on board their own vesscls. 'The Danes having cast anchor at the third road, a servant of Gotske Lindenan, a brave and enterprising soldier, immediately prayed his master to allow him to land alone to reconnoitre these savages. He said he would endeavour cither to entice them by his merchandise, or to save himself in case they had any evil 
design against him. The master allowed himself to be persuaded by the importunity of the servant; but the man had hardly set foot on the land when in a moment he was seized, killed, and torn in pieces by the savages, who retired from the port after this and hid themselves from the cannon of the Danes. 'The knives and swords of these savages were made of horn or tecth of those fish which they call unicorns, ground down and sharpened with stones; they pierce quite as well as if they were made of iron and steel.

Gotske Lindenan, seeing that he could do nothing in this country, set sail for Demmark. One of his Greenland prisoners was so wretched at the thought of leaving his country, that in despair he threw himself into the sea and was drowned. In returning, the Danes found the ressel which had strayed on their outward passage; but they were only five days together, for a tempest which rose scattered all five, and they did not meet again for a month after the storm was over. 'They arrived at Copenhagen, after much trouble and peril, the 5th of the following October.

'The king of Denmark undertook the third and last voyage which he had caused to be made to Greenland, with two large vessels, under the command of a captain of the country of Holstein, named Karsten Richkaritsen, to whom he gave Norwegian and Icelandic sailors to guide and pilot lim. 'The chronicle says, that the captain left the Sound on the 13th of May, but does not mention the year; nor have I ever been able to learn it. On the eighth of the following June he discorered the summits of the mountains of Greenland, but could not land on account of the ice which was all round it, and which extended some distance into the sea. Upon this ice were also large heaps of ice, which resembled luuge rocks; and the chronicler remarks in this place, that there are years when the ice does not melt even in summer. The Danish captain was obliged to return without effecting anything, and he was necessitated to do so because his second ressel was separated 
from his own in a storm, so that he was alone when he came to the ice. 'T'he king of Denmark accepted his excuses and the impossibilities he allegred.

You will now ask me what became of the nine savages who remained after the two first voyages. I will here give you a short account of them. The king of Denmark appointed persons, who had the particular charge of fecding and kecping them, but in such a manncr, however, that they should be free to go wherever they wished. They fed them with milk, butter, cheese, raw flesh, and uncooked fish, in the same manner as they lived in their own country, because they could not get accustomed to our bread and meat, still less to our wines; they enjoyed nothing so much as large draughts of oil, or of the fat of whales. They often looked towards the north, and sighed with so much regret after their own comntry that their guards, being lenient, those who coukl seized their little boats and oars and put out to sea to try the passage. But a storm which smrprised them at ten or twelve leagues from the Sound, cast them on the coasts of Schonen, where the country people took them and sent them back again to Copenhagen. This obliged the guards to watch them with more care, and give them less liberty. They fell ill, howerer, and died. 'There were still five living and in good health at the time the Spanish ambassador came to Denmark. The king of Norway, wishing to amuse him during his visit, showed him these savages, and allowed them to exercise with their little boats on the water. 'To understand the shape and style of these boats, picture to yoursclf, sir, a wcaver's shuttle ten or twelve fect long, made of whalebone, hroad, and about the thickness of a finger, covered over and macle like the sticks of a parasol with skins of seals or walruses, scwn with sincw. This machine has a round opening in the middle about the size of a man round the flanks, going to a point at each end in proportion to its thickness in the middlle. 'The strength and neatness of the structure depend on 
the two ends where these sticks are joined and fastened together; on the opening or circle abore, to the circumference of which all the sticks must be brought; and on the half circle below, which is fastened to the upper circle like a basket-handle turned upside down. Picture to yourself that through this half circle pass or terminate both the ribs and the crossribs, and the whole is so well sewn and bound and so well stretched, that it is capable, from its lightness and the skill with which it is built, to bear the tossings of a storm in a high sea. The savages sit in the bottom of these boats through the opening above, with their feet extended to one end, and they fill up the hole by fastening over it the lower part of their under waistcoasts, made of the skins of seals and walruses: they close up the wrists of their sleeves and cover their heads with caps fastened to the edge of their dress in such a manner, that when a storm overturns them (which is very often the case), the water cannot enter by any place, either in the boats or their clothes. They always come up again on the water, and thus save themsclves much better in a storm than if they were in large vessels. They only use one little oar, fron five to six feet in length, smooth, and about half a foot in brealth at each end. They grasp it with both hands at the micklle, which is round, and use it with equal poise to keep their equilibrium, and also as a double oar to row on both sides. It was not without reason that I have compared these boats to weaver's shuttles; for the shuttles from the hands of the most skilful weavers, do not run faster in the loom than the boats managed by these oars, with the skill of these savages, run on the water. The Spanish ambassador was delighted to see the five savages practise this exercise. They crossed and interlaced with each other with such rapidity, that the eye grew quite confused with looking; and so skilfully was it done, that not one of them touched each other. 'The king wished to prove the swiftness of one of these little boats against a sloop equipped with sixteen 
good rowers, but the sloop had great difficulty in following the boat.

The ambassador sent to each of the savages a sum of money, and they all employed it in dressing themselves in the Danish fashion. Some of them put large feathers in their hats, were booted and spurred, and sent word to the king of Denmark that they would serve him on horseback. This lively humour did not last very long, for they relapsed into their usual melancholy, and as they thought of nothing but how they might return to Greenland, two of those who had put out to sea and whom the storm had cast on Schonen, and who were less suspected than the others, because it scemed unlikely that they would expose themselves a second time to the perils they had encountered, seized their boats and succeeded in regaining the north. They were pursued and overtaken near the mouth of the sea, but only one was taken, the other cscaped, or, rather, was lost; for it does not seem probable that he ever could have arrived in Greenland. They noticed in this sarage, that he burst into tears whenerer he saw a child hanging on its mother's neck or with its nurse; from which they judged that he was married, and wept for the loss of his wife and children. Those who were kept back at Copenhagen were guarded still more strictly than before, which only increased their desire of returning to their country, and their despair of ever doing so. They nearly all died of this regret, and there only remained two of these mhappy Greenlanders, who lived ten or twelve years in Denmark after the death of their companions.

The Danes did all in their power to keep them alive, and gave them to understand that they would be treated like their friends and fellow-countrymen, for which, in a certain measure, they were grateful. They tried to make them Christians, but they could never learn the Danish language, and it was impossible to make them understand our mysteries. Those who watched them more closely, often saw them raise their 
eyes to heaven and worship the rising sun. One died from illness at Kolding, in Jutland, from having fished for pearls in winter. You will find, sir, that the mussels of Demmark are full of pearl-seeds and imperfect pearls, and those who eat them hardly find anything else than this kind of gravel under their teeth. A great number of these mussels are caught in the river of Kolding. Some of them have fine pearls, a great many very small ones, and others rather large and round. This Greenlander had told them that they fish pearls in his country, and that they were elever in this fishing. The governor of Kolding took him to his government, and gave him wherewith to practise in the river where the pearls are. The sarage succeeded marvellously, for he went under the water like a fish, and never came up without mussels containing very fine pearls. The governor thought that if this continued, he should soon have to weigh the pearls by bushels. But his avidity put an end to his hopes; for winter came suddenly upon him, and not having patience to wait till the summer to continue his fishing, he sent this poor savage under the water like a dog, and made him go so often in among the ice that he died in consequence. His companion could not be consoled for his loss, and found means, on one of the early days of spring, to get possession of one of the little boats. He embarked secretly, and passed the Sound before they were aware of his flight. He was speedily pursued, but as he had got the start, they only orertook him at thirty or forty leagues' distance out at sea. They made him understand by signs that he would never have known where to find Greenland, and that undoubtedly the waves would have swallowed him up. He answered by signs, that he should have followed the coast of Norway to a certain point, whence he would have crossed, and have been guided by the stars to his country. On his return to Copenhagen he fell ill and died.

This was the end of all these unhappy Greenlanders: 
they were, as I have described the Laplander's to you, short and broad-shouldered : forti pectore et armis : tawny, flatnosed, and, like them, they hat thick and turned-up lips. 'The spoils of the boats, oars, their arrows and their bows, their slings, and clothes, are kept in Denmark. We saw in Copenhagen two of these boats, with their oars; one at the house of M. Vormins, and the other at that of the ambassador. 'Their coats, made of seal and walrus-skins, their' shirts of the intestines of fish, and one of their under-shirts made of the skins of birds, with their feathers of different colour's, are hung for curiosity in the cabinet of M. Vormius; with their bows and arrows, slings, knives, swords, and the javelins which they use in fishing, and which are pointed in the same way as their arrows, with horn or tecth sharpcned down. We saw there a Greenland calendar, composed of twenty-five or thirty little bones, fastened to a strap of sheepskin, which is not used by any but the original Greenlanders.

The king of Denmark was disheartened about Greenland, and did not send there any more; but the merchants of Copenhagen undertook this navigation, and formed a company, which still subsists, nucler the name of "the Company of Gireenland", in which were engaged persons of rank. This company sent two resscls out in 1636 , which proceeded along Daris' Gulf, and to that part of $\mathrm{Ncw}$ Greenland which is on the coast of this gulf. As soon as they had cast anchor, eight savages put off to them in their little boats. 'They were on deck, and, on one side, the Danes had displayed their knives, looking-glasses, needles, etc., and the savages, on the other, their skins of $\log s$, foxes, seals, with a quantity of horn, which they call unicorn; when, with no other object than to celebrate some toast they were drinking, a cannon was fired from the vessel. The savages, terrified at the noise and the shock, rushed from the side of the ressel and launched into the sea, from which they never 
raised their heads till they had got two or three hundred feet from the vessel. 'The Danes, surprised at the novelty of this fact, made sigus to them to return, and assured them that they would not hurt them. The savages believed them, and returned to the vessel after they had got rid of their fear and saw no more smoke, and the air had regained its former tranquillity. Their manner of trading is this: they choose what strikes their fancy amougst the merchandise of the foreigners, and make a heap of it; they then make another heap of the goods they will give in exchange, and they all arrange these heaps until they agree.

At the time the Danes were trading with these savages, they saw from the vessel one of the fish which have the hor'ns and are called umicorns, lying down on the grass of the shore, which the return of the tide had left dry. They maintain that it is the habit of the seals to go on the grass, and that these fish, which are like large sea-oxen, have this habit also. The savages went in crowds to this fish, killed it, pulled out its teeth and horn, and sold it to the Danes immediately. 'This fish, which cannot defend itself on land, is very ferocious in the water. It is to the whale what the rhinoceros is to the elephant. It fights with it and pierces it with its tooth, which serves for a lance; they say that it has struck vessels with such force that they break and sink.

But a commerce of trifles was not the principal object of this voyage. The pilot who conducted them, had known a bank on this coast where the sand was of the colour and weight of gold. He speedily proceeded to this bank, and having filled his vessel with the sand, told his companions that they were all rich, and set sail for Denmark. The Grand Master of this kingdom, who is chief of this company, and who, in fact, principally formed it to reconnoitre the country and to visit it at leisure, was surprised at so sudden a return; but the pilot, who felt aggrieved, told him that he 
had a mountain of gold in his vessels. But he had to do with a man who is not very credible. He asked for some of this sand, and having had it examined by the goldsmiths of Copenhagen, they told him they could not get a single grain of gold from it. The Grand Master, enraged that the pilot should have allowed himself to be so duped, and to show that he had no part in it, commanded him to go immediately to the Sound, where his vessel was, to weigh anchor, and to proceed into the main sca in the Baltic, to bury there his gold and his folly, and never again to speak of either. The pilot was obliged to obey him, and, whether it was because he thought he had thrown all his wealth into the sea, or that he beheld himself fallen from the high hopes of riches he had conceived, it is certain that he died very soon after from one or the other cause of grief. We cannot blame the Grand Master for his harsh orders to the pilot; for he told me that they have since found in the mines of Norway similar sand to that of Greenland, of which I have just spoken; and that an intelligent workman in minerals and mines, who came not long ago to Copenhagen, extracted very good gold from it, and in a quantity proportionate to the sand. He was incited to this precipitation by the ignorance of the other workmen, who would have known no better how to extract the ore even from the material in which it is found in Peru than from this sand.

This is the last voyage that has been made to New Greenland, and it is from this voyage that the large picce of horn was brought, which the physician of the Grand Duke of Muscovy said was only the tooth of a fish. The host of the ambassador of Copenhagen, who is of this company, showed us this piece, which he values at six thousand rix dollars. The Danes, before their departure from Greenland, detained and secured two savages to take to Denmark. 'They set them loose when they got out to sea, and they, excited with love for their country, finding themselves free, jumped into the 
water to swim to their country. It is very likely that they were drowned on the way, for they must have been at too great a distance from the shore.

'Thus far I have written all that I could learn of Old and New Greenland. Of the Old, which the Norwegians inhabitcd, and of the New, which the Norwegian, Danish, and the English discovered in seeking the Old. The passages across from Iceland to the Old Greenland were probably blocked up by the fall of ice, which the severe winters and the rough north-east winds drove from the frozen sea and heaped up in this channel; it is also likely that the sailors, who could not keep to the old route, were obliged to follow the one which led them to Cape Farewell and Davis' Gulf, the shore of which is opposite to the east, and is that which they call New Greenland. Now it is possible that the ancient passages to Greenland from Iceland have been blocked up, from the fact of the route having been lost; and the Icelandic Chronicle, of which I have spoken to you before, furnishes us with a more certain proof in the chapter on this navigation, where it is stated that halfway between Greenland and Iceland is Gondebiume Skeer, which is a collection of little rocks and islets scattered in this sca and infested with bears, where the progress of the ice has probably been stopped, and it has been so strongly bound together that the sum, not being able to melt it, it has become like a petrifaction; so that this road being closed, the communication they had with Greenland was also broken off; and thus no news whatever could be had of them, neither could they hear what had become of the poor Norwegians who inhabited it. It would seem that the same black pestilence which ravaged the people of the north, about the year $13 \pm 8$, and which was doubtless carried from Norway, destroyed them like the others. I would willingly believe that Gotske Lindenau, who liept, as I have told you before, the route of the north-west in his first voyage, had reached Old Greenland, or very nearly 
reached it, and should be inclined also to believe that the two sarages whom he took from this place were perhaps descendants of those ancient Norwegians, whose end we are anxious to find ont; but so many people who have seen and studied them at Copenhagen, assured me that neither these men nor those who were brought from Davis' Gulf, although they differed among themselves in language and mamners, had anything in common with this same language or those manners with Demmark and Norway; and the language of these savages was so different from that of this part of the world, that the Danes and Norwegians could understand nothing of it.

The Danish Chronicle remarks, that the three sarages whom the English pilot brought from Davis' Gulf, spoke so quickly and stuttered so much, that they pronounced nothing distinctly but these two words, "Oxa indecha", of which they conld never learn the signification. It is certain that what we call the OId Greenland, was only a small part of all this extensive northern land which I have described to you, that that was the nearest shore to the passage of Iceland, and that the Norwegians who inhabited it dicl not proceed further inland, any more than those who discovered New Greenland, who only touched there at its ports and coasts, and, as you have seen, hardly dare hazard setting foot on land. The Grand Master of Denmark told me that the Danes, in the last royage of Greenland, which was made in 1636, haring inquired by signs of the Greenlanders with whom they traded, whether there were more men made like them beyond the mountains which they saw inland at ten or twelve leagues from the sea, these sarages answered them by signs and demonstrations, that there were other men beyond these mountains who had no hair on their heads, and that they werc men of great size and carried large bows and arrows, and that they killed all those who came near them. Now, neither these men nor the land they inhabit, hare been ever known to any 
one with whose history we are acquainted, and the whole of Greenland is, as I have already informed you, larger beyond comparison than that which the Norwegians, Danes, and English have discovered.

At the beginning of this history I proposed to lay before you two points: first, that it is not certain that Greenland is part of the continent of Asia on the side of Tartary ; and secondly, that it is part of the continent of America. As regards the first, I must tell you that they have not yet been able to penetrate the ice of Nova Zembla, to see if there is a passage by that way into the eastern sea, and that, up to the present time, that passage has been in rain attempted by the most determined sailors of whom we have heard. 'This navigation, which has discouraged the best pilots of the north, has limited their expeditions to Spitzbergen, which the Danes reckon in the country of Greenland, wherc is the great whale fishery, and whither our Biscayans and the Dutch make royages every year. I must here tell you what the Grand Master of Denmark told me of this land and sea. He was not content with informing me verbally, but was so good as to send it me in writing, and some day I hope to show you his letter, which I preserve as a proud mark of his favour and generosity. But why am I talking of showing you his letter? I hope you will soon see His Excellency himself, for we have just heard that he has left Copenhagen to go to France as ambassador extraordinary from his master, the king of Denmark. He is gone, with his wife, the Countess Eleanor, daughter of the king of Denmark, whose worth is equal to her noble birth, and who possesses her share of royal virtues. This is the hero whose qualities I described to our dear friend, M. Bourdelot, when I told him of what was passing at the Bridge of Brensbro, ${ }^{1}$ where the celebrated conference took place between the plenipotentaries of Sweden and Denmark for the

1 The treaty of peace at Brömsbro or Brömsebridge, between Calmar and Carlscrona, in 1645. 
peace of those two countries, and which our illustrious ambassador so gloriously achicved. Here met the two first men of the north, the Grand Master of Denmark, of whom I am speaking, and the high chancellor of Sweden. 'They looked upon each other with pride and veneration. The work was one fully worthy of our ambassador, who is truly called Extraordinary, which, in making peace between these two nations, cemented the friendship of two such great men. I hope to speak on another occasion of the High Chancellor of Sweden, and do not intend in this place to write a panegyric on the Grand Master of Denmark; but shall content myself with saying, that when you have seen this great minister, you will be able to judge of his heart, which is so noble, of his mind, which is so refined, and of his mien, which is so high that he can not only support crowns by his comnsel, but has also a head to carry on this mighty empire. Add to all these heroic virtues that he is an accomplished philosopher, neither fond of vanity nor ostentation, a man of the most generous sentiments, and most instructive in his conversation.

His Excellency had in his service a Spanish gentleman named Lconin, a naturalist, of a learned and inquiring mind, whom he sent to Spitzbergen, that he might hear from him on his return what he saw and heard. The report he made is briefly this. 'The country is in the seventy-eighth degree of elevation, and rightly called Spitzbergen, on account of the pointed mountains which are, so to speak, sown or planted upon it. 'These monntains are composed of gravel and little flat stones, like small pieces of grey slate, one on the top of the other; they are formed of these little stones and of the gravel which the wind collects together, or which the rapours bring with them. They grow perceptibly, and the sailors every year find new ones. Leonin went pretty far into the country, and only found this kind of pointed mountains, with which the country was covered, and met 
with nothing on the road but reindeer. He was, however, surprised to see at the top of one of these mountains, and a league from the sea, a little mast of a vesscl, to which was attached a pulley at one cnd; and when he asked his sailors whom he had brought with him who had brought it there, they told him they did not know, and they had always seen it thcre. It is probable that the sea washed formerly near this mountain, and that it was the remainder of some shipwreck. There are meadows in this part, but the grass is so short that it can scarcely be discovered from the land or from the stones; for, properly speaking, this land has no carth, but is composed of little stones, between which and this small grass springs up a kind of moss, like that which grows on the trees in onr climate, on which the reindecr of this country feed and become so fat, that the Grand Master brought some of them which had four fingers' breadth of fat. 'This country neither is nor can be inhabited on account of the cold; for although the sun does not set at all for four months, and during six weeks of that time does not descend within three ells of the horizon (speaking in the Danish fashion and conformably with Tirgil's measurement of the heavens); that is to say, although at the midnight, if one may so speak, of that country the sun for six weeks does not approach in its descent lower than within about nine or eleven and a half degrees of the horizon, yet, for all that, the clearer and brighter the sun is, the colder it is. It is impossible to live near these mountains, for they have no solidity, and there cxhales from them so cold a vapour that one is frozen, however short a time one stays there. To guard against this severity, it is better to go where the sun shines on all sides.

'There are great numbers of bears in this country, but they are all white, and much fonder of the water than the land. 'They are found in the open sca, swimming and climbing upon large pieces of ice. The Grand Master got some live ones 
and fed them at Copenhagen. When he wished to amuse his friends, he went on the water, and made these bears jump in some sandy place, pretty deep, but suffieiently elear for them to be scen through the water. He told me it afforded him particnlar delight to see these animals playing at the bottom of the sca for two or three hours, and they would have lived there for whole days without difficulty, if they had not been brought up by cords and chains to which they were fastened.

The sea of Spitzbergen produces a great number of whales; they take them two hundred feet in length, and of a thickness proportionate to the length. The generality are abont one hundred and thirty or one hundred and sixty feet. 'T'hey have no teeth. When these large bodies are opened, they find nothing but ten or twelve handsful of little black spiders, which are engendered by the bad air of the sea; and also a little green grass, which springs up from the bottom of the water. It is probable that these whales live neither on this grass, nor on these spiders, but on the water of the sea, which produces the grass and the spiders. This sea is sometimes so covered with these kind of inseets that it is quite black with them; and it is an infallible sign for the fishermen that the fishing will be good, for the whales follow the water that engender's this pestilence. They then take such large whales, and in such great numbers, that the sailors will not know how to carry away all the fat they have melted, and are obliged to leave some on the ground, with which they come to load themselves the year after. You will remark, sir, that nothing rots or becomes corrupt in this land; corpses, which have been buried for thirty years, are as fine and sound as they were when alive. A long time ago some huts were built in which to cook the fat of the whales, but they are always exactly as they were when first built, and the wood of which they are made is as sound as it was the day it was eut off the tree. 'To say the truth of these northern 
countries, dead bodies licep well, but the living always fare ill. Witness poor Leonin, who returned from his royage numbed with the cold, and died soon after.

The birds this country produces are all sea birds, and not one lives npon land. There are great numbers of ducks, and many other kinds of winged fowl which are unknown to 115. The Grand Master of Denmark not being able to obtain any of these birds alive, cansed some dead ones to be brought to Copenhagen. They had beaks and feathers like parrots, and feet like ducks. Those who take these birds say that they have a very sweet and pleasant song, and that when they sing altogether a melodious conecrt is formed from their warbling on the water.

The sailors who go to Spitzbergen for the whale fishery get there in the month of July, and leave again towards the middle of August. They would not be able to land, on account of the ice, if they arrived there before the month of July; and would not be able to leave it, for the same reason, if they set off later than the middle of August. In this sea are found immense blocks of ice, sixty, seventy, or eighty fathoms thick;

Quæ tantum rertice ad auras Aerias,

Quantum radice ad Tartara tendunt;

for there are places in this sea where the water is frozen from the bottom to the top, and on the surface of this are blocks of ice as high above as the sea is deep below. These picces of ice are clear and sparkling like glass. What renders the navigation of this sea dangerous is, that there are contrary eurrents in these parts, where the ice melts and freezes again in a moment.

It does not seem strange after this that we should be unable to determine anything certain about our first doubt, or resolve assuredly that Grecnland is or is not part of the continent of Asia and of Tartary. The distance that there is from our seas to these frozen scas, the uncertainty of 
finding them melted, the heary storms which gather upon these waters, the inexperience of the routes, the barren parts that are found there, and, what is worse, the fact of there being no help and no retreat in these deserts; - all these difficulties accumulated frustrate the designs of inquiring persons, and deprive them of the means of discovering the facts of which they are in search. 'The same difficultics, and, consequently, the same mneertainties, are met with for the sccond doubt as for the first; and we should not be able any better to determine that Grecnland was or was not part of the continont of America.

This is what I propose to show you here in the narrative which I promised you of the Danish captain, Jcan Munck, who attempted, as I have told you, a passage to the cast, by the north-west coast between America and Greenland. I sluall not be wandering from my subject in writing you this narration, for besides being amusing, it refers to Greenland and the adjacent islands. The present king of Norway ordered Captain Munck to go and seck out a passage to the East Indies by a strait and a sea which separates America from Greenland. An English captain named Hudson, had discovered this strait and this sea some time before, with the same design, but he was lost in this navigation, and it was never known how. It is certain that if he had the boldness of Icarus to fly by an unknown route, his feathers would have been frozen quicker than they would have thawed in this adventurous undertaking. His enterprise had this in common with that of Icarus, that this strait and this sea bore afterwards the names of IIndson's Strait and Hudson's Sca.

Captain Munck left the Sound for this voyage May 16th, 1619, with two vessels, that the king of Norway had giren him. There were forty-eight men in the larger vessel, and sixtcen in the smaller, which was a frigate. He arrived on the 20th of the following June at the cape called in the Danish language Farvel, in Latin, Cape Vale, or in French, 
de Bon voyage. Doubtless it is thus called because those who go beyond this cape seem to be going into another world, and to be taking a long leave of their friends. Cape Farewell is, as I have told you, at sixty and a half degrees elevation, in a country of mountains covered with snow and icc. It would be difficult to represent its form, on account of the snow and ice, which vary, and on account of their whiteness, which dazzles the eyes. Captain Munck being at this cape, took the route from the west to the north to enter Hudson's Strait, and found a quantity of ice, which he avoided beeause he was in the open sea. He advises those who undertake this voyage, not to go too far towards the north in this part, on account of the ice and the eurrents, which are rough on the coasts of America. He relates that on the night of the 8th of July, being on this sea, he saw so thick a fog, and it was so cold, that the ropes of his ressel were eovered with long icicles, and were so frozen and hard that they could not use them for their work. He then says that in the afternoon, from three o'clock until sunset, it was so hot that they were obliged to keep on only their shirts, for they could not bear their clothes.

He cntered Hudson's Strait, which he callerl Christian Strait, after the king of Denmark his master, and landed the same night on an island which is off the eoast of Greenland. Those whom he sent to recomnoitre this island told him that they had seen traces of men, but that they had found no men. The next morning they met a number of savages, who were surprised at the landing of the Danes, and ran in disorder to hide the arms they carried behind a heap of stones near the place where they were. After this they came forward and gracionsly returned the salute the Danes gave them, observing carefully, however, all the time to keep between the Danes and the place where they had hidden their arms. But the Danes succeeded so well in diverting and amusing them, that they gained their treasury, where they found a 
heap of bows, quivers, and arrows. The savages, disconsolate for their loss, conjured the Danes with gesticulations of prayer and submission to give them back what they had taken. 'They gave them to understand by gestures that they only lived by lunting, that these arms were their means of subsistence, and that they would give up their elothes to have them back. The Danes, moved with compassion, returned them, and the savages fell on their knees to thank them for so much condescension. The courtesy of the Dancs towards the savages did not stop there. They displayed their merchandise and made them presents of their trifles, which the sarages admired and received with joy; and in exchange gave to the Danes many kinds of birds and fat of different fish. One of them, who had cast his eyes on a looking-glass and who was admiring himself in it, was so astonished to see himself that he took it, put it in his bosom, and ran away. But the Danes only laughed, and not less when all the savages ran to embrace one of their companions, and caressed him as if they had known him for a long time, because he had black hair, and was flat-nosed and tawney, in a word, because he resembled them.

Captain Munck left this island the day after, which was the ninetcenth of July, and having set sail to continue his route, was obliged to put back on account of the ice and to retire to this same port again, where, notwithstanding all the trouble he took, he could see no more islanders. 'The Danes found nets spread along the shore, to which they fastened knives, looking-glasses, and other rough trinkets, to invite them to return; but not onc came again, cither because they were afraid of the Danes, or because they had been expressly forbidden by some sort of judge or governor to have any more trading with them. Captain Munck, not being able to find any men, found and took a great number of reindeer in this island, which he called Reinsundt, that is to siy, the gulf of reindecr; and he called the port where he 
landed, from his own name, Munckenes. This island is in sixty-one degrees twenty minutes of elevation. He set up there the name and arms of the king of Denmark his master, and took his departure on the 2.2nd of July. But he ran much risk from the violent storms which rose, and from the shock of icebergs, which damaged him so much that it was with diffculty that he saved himself on the twenty-cighth of the same month, between two islands, where he cast all his anchors and made fast his vessels to the land, so impetuons was the storm even in the port. 'The return of tide left the Danes dried up upon the mud, and the flow, which eame rapidly, brought them so much ice, that they were in as great danger of perishing there as in open sea, if they had not fortified themselves with great eare and trouble. Between these two islands was a large piece of ice, twenty-two fathoms thick, which became detached from the islands and separated in two; these two pieces fell from both sides to the bottom of the sea, and stirred up such a tempest in falling, that one of their sloops was very nearly lost. They saw no men in these two islands, but traces and evident marks that there were, or had been some. 'They found there some minerals, and among others some tale, of which they took some tons. There were other islands near these, which appeared inhabited, but the Danes could not get to them becanse the entrance to them was inacessible, and so wild that they never saw anything like it before. 'These islands are in sixty-two degrees twenty minutes, and fifty leagues further on in Christian Strait. Captain Munck called the gulf or strait where he landed Haresunt, which means gulf or strait of hares, from the great number of hares which he found in this island; and there set up the standard of Chistian IV, king of Denmark, which they used to represent thus, $\dot{C}$.

He left these islands on the ninth of Angust, and sailed towards the west south-west with a north-west wind, and on the tenth landed on the south coist of the Christian Strait, 
which is the coast of America. Having left there, he found a large island on the north-west, which he called Sneoculand, or the island of snow, because it was corered with snow. The twentieth of August he took his course from the west to the north, "And then," says the narrator, "I kept my own route at the elevation of sixty-two degrees twenty minutes." But the fogs were so thick that they saw no land. "Althongh," says he, "the breadth of Christian Strait was only sixteen leagues in this part." This leads us to suppose that it is larger in other parts. He entered the strait in Hudson's Sea, the name of which he changed, as he had done that of the strait, and gave it two for one. He called that part of this sea which is opposite America, Mare Novum, and that which is opposite Greenland, Mare Christianum. if, indeed, this coast ought to be called Greenland. He kept as much as possible to the west north-west route, until he had reached the cleration of sixty-three degrees twenty minutes, where the ice arrested his progress and obliged him to winter on the coast of Greenland, at a port which he called Munckenes Vinterhaven or the port of Munck's winter ; and called the country New Denmark. He does not mention in his narrative many places that he passed in going to this port, because he says he has made a map of them, to which he refers the reader. He only mentions two islands in the Christian Sea, which he calls the Sister Islands, and another larger one near the New Sea, which he calls Dixe's Oeuland. He advises those who navigate Christian's Strait to keep as much as possible in the middle of the strait, on account of the rapid and contrary currents which are found on both of these coasts by the opposite tides of the two seas, the Ocean and the Christian Sea, the ice of which being extraordinarily thick, the blocks dash against each other with such violence that the vessels that are between them are irreparably shattered. He says that the ebling of the Christian Sea 
takes place regularly every five hours, and that its tides follow the course of the moon.

Captain Munck arrived on the seventh of September at Munckenes Vinterhaven, where he refreshed himself and his men. He brought in his vessels some days after, and put them under shelter from the shock of the icebergs in a port near the first, and here he repaired them as well as he could. His companions were particular to provide themselves with huts to defend themselves from the bad weather, and from the winter, which had taken them by surprise. This port was the mouth of a river, which was not frozen in the month of October, although the sea was frozen up in many parts. Captain Munck reports, that on the seventh of this month he went on board a sloop to reconnoitre this river, and that he conld not go any further than about a league and a half, on accomnt of the stones which blocked it up. Not being able to find a passage by the river, he took some of his soldiers and sailors and walked three or four leagues inland to seek for men; but they could find none. Returning by another route, they found a rather large stone raised, upon which was painted an image representing the devil, with his claws and horns. Near this picture was a place eight feet square, closed up with smaller stones. He remarked at one of the sides of this square a heap of little flat stones and tree-moss mixed together. At the other side of this square was a flat stone, put in the form of an altar on two other stones; and on this altar three little pieces of coal, crossed one over the other. But although Captain Munck saw no one on his road, yet he met in different places with similar altars with picces of coal laid upon them, like the preceding, and everywhere that he saw these altars he also found traces from which he conjectured that the inhabitants of this country assembled to sacrifice at these altars, and that they sacrificed to fire or with fire. He also saw that everywhere where these traces of men were seen there were bones, and from that he con- 
jectured that they were the remains of sacrifieed animals, which the savages had eaten after their fashion, that is to say, raw, and torn in picces as logs tear them, with their paws and tceth. He remarked in passing through the woods, quantities of trees eut with iron and steel instru. ments. They found also dogs bridled or muzzled with straps of wood. And what confirmed him more than all in the belief that this comntry was inhabited, was, that he saw marks of tents, which had been raised in different parts; and in the same places found pieces of the skin of bear's, wolves, stags, goats, dogs, and seals, which had served as corerings for these tents. These appearances made it manifest that these people lived like the Seythians, and encamped themselves in tents like the Laplanders.

'The Danes, when hutted and established in their winter quarters, made a good provision of wood to keep themselves warm, and also of renison for food. Captain Munck first killed with his own hand a white bear, which he and his companions ate, and expressly state that they found it very good. They killed a number of hares, partridges, and other birds, which he does not mention, but which he says were very common in Norway. He also says they took four black foxes, and some sables, which is the name they give everywhere in the north to the sobeline martens.

One thing which puzzled the Danes was, that they saw in the sky of this country things which were not usnally seen in the sky at Demmark. 'The narrative says, that on the twenty-serenth of Norember there appeared three suns distinetly formed in the heavens, ${ }^{1}$ and remarks at the same time that the air of this country is very thick. 'Two suns, no less distinct, appeared on the 24th of the following January ; and two others less distinct on the 10th of December, which is the

1 For the representation of a similar phenomenon, see illustration facing page 72 of "Gerrit de Veer's Three Voyages by the NorthEast," edited for the Hakluyt Society by Dr. Beke. 
20th accorcling to our manmer of reckoning; at eight o'clock in the evening, there was an eclipse of the moon. The same night the moon for two hours was surrounded by a very bright circle, in which appeared a cross which cut the moon in four. 'This meteor appears to have been the foreteller of all the evils that these Danes would have to suffer, and of their almost utter ruin, as you will hear.

The winter became so severe and sharp that they found ice of three hundred and of three hundred and sixty feet thick. The beer and wine, even the purest Spanish, and the strongest brandy, were frozen from the top to the bottom of their vessels. The cold, which broke the hoops and burst the tuns, left the beer and wine in the consistency of ice, so hard that they were obliged to cut it with hatchets in orcler to melt and drink it. The vessels of pewter and copper, when, by neglect, they had overnight forgotten the water, were the next morning eracked and broken at the place where the water was frozen. This severe season, which did not spare metals, did not spare men either. The poor Danes fell ill, and the sickness increased among them with the cold. 'They suffered from looseness, which did not leave them until they were carried off. They died one after the other and so many, that at the commencement of May their captain was obliged to guard his tent himself. 'This illness inereased instead of diminishing at the beginning of spring. It loosened the teeth of the sufferers, and ulcerated the inside of their mouths so much, that they could only eat bread steeped in melted water. It attacked the last dying men towards the month of May with so much malignity, that to all these evils was added dysentery, and so sensitive were the nerrous parts, that it seemed as if some one was pricking them all over with the point of a knife. 'They visibly shrunk, their arms and legs became number, and their bodies livid and black, as if they had been beaten. The description of this sickness is really what is called scorbutic, well known and 
common in all the northern seas. 'T'hose who died could not be buried, becanse no one had strength enough to put them under ground. 'l'he bread even fell short for those invalids who remained. They were obliged to search among the snow, where they found a kind of strawberry, which sustained and nourished them after a manner. 'They ate them as they gathered them, for they could not make any provision of them, because they keep under the snow, but wither a short time after they are taken up.

The narrator marks the twelfth of April as a memorable day, for it rained, which it had not done for seven months in these quarters. The spring brought a thousand kind of birds, which had not appeared during the winter, and these dying men could not catch any of them on account of their debility. About the middle of May they saw wild geese, swans, and ducks, and an infinite number of little tufted birds; swallows, partridges, and woodpeckers, crows, falcons, and eagles. Captain Munck himself fell ill, like the rest, on the fourth of June; and remained in his hut four whole days withont going out and without eating anything, overcome with misfortunes. He prepared for death and made his will, by which he prayed the passers-by to bury him, and to send the journal that he had made to the ling of Denmark his master. At the end of the four days lie felt a little stronger, and left his tent to see his companions, dead or alive. He only found two alive, out of the sixty-four he had bronght with him. These two poor sailors, delighted to see their captain about, went to him and brought him to their fire, where he came a little to himself. They encouraged one another and resolved to strive to live, but they did not know how. They thought they would scratch away the snow and eat the grass which they found underneath. Happily they found some particular kind of roots, which nourished and comforted them in such a manner that they were well again in a few days. 'T'he ice began to break about this time, which was the eighteenth of June, 
and they caught plaice, trout, and salmon. Their fishing and hunting fortificd them, and the courage they took rosolver them upon attempting in the state they were in, if they could pass through so much sea and through so much peril, to arrive at Denmark. It began to be a little warmer now, and it also rained a little; whence there arose such a quantity of gnats that they did not know where to go to get out of their way.

They left their large vessel and embarked in their frigate on the sixteenth of July. They sailed from this port, where I told you they had put their vessels under cover from the ice, and which Captain Munck called after his own name, Jens Munckes Bay, which means the bay or port of John Munck. He found the Christian Sea covered with floating ice, and here he lost his sloop, and had great difficulty in disengaging his own vessel; for the ruddcr was broken, and whilst waiting to have it repaired he fastened his ressel to a rock of ice, which followed the current of the sea. He freed himself from this ice, which sank, and found his sloop again ten days after having lost it. But he was not long thus, for the sea became frozen again and melted soon after, and continued varying in this manner, freezing and thawing from one day to another. He went through the end of Christian Strait, came again to Cape Farewell, and re-entered the ocean, where he was overtaken on the third of September by a severe tempest, in which he was nearly lost; for he and his sailors were so weak that they were obliged to give up all direction of the ship, and to surrender themselves to the mercy of the storm. The rigging of their sails was broken, and the sails were overturned into the sea, whence they took all possible pains to get them out. The storm abated for some days, and gave them time to arrive on the 21 st of September at a port of Norway, where they were anchored with the end only of an anchor which was left them, and thonght. they were safe. But the storm assailed them the very same 
day in this port, and with such fury that they had nerer been in such peril of being lost. Fortunately they were sared in a place where others perish, for they found a shelter among the rocks, from which they gained the land and refreshed themselves, and some days after arrived in Denmark in their frigate. Captain Nunck related the circumstances of his voyage to the king his master, who received him as one does a person who has been thought lost.

It secmed as if this ought to have been the end of the captain's misfortunes; but his history is a chequered one, and deserves to be known. He remained some years in Denmark, where, after having long pondered upon the defects he had made in his former voyage from ignorance of the places and things, and on the possibility of finding the passage that he sought for in the east, he became seized with the desire of undertaking this royage again. And not being able to undertake it alone, he engaged in this party gentlemen of distinction and able citizens of Denmark, who formed a distinguished company and equipped two ressels for this long expedition, under the conduct of this captain. He had provided against all the inconveniences and defects from which he had suffered on the first royage, and he was, as it were, on the point of embarking for the sccond, when the king of Denmark asked him the day of his departure, and, passing from one subject to another, reproached him with having lost by his bad management the equipment that he had given him; to which the captain answered rather sharply: this made the king angry, and he pushed him in the stomach with the end of a stick he held in his hand. The captain, enraged at this affront, went home, and took to his bed, where he died ten days after of displeasure and hunger.

To return to the subject for which, principally, I have given you this long account; it results from what I have written to you, that there is a long and broad strait and a wide sea at the end between America and Greenland; and 
not knowing where to limit this sea, we shall not be able to judge if Grcenland is part of the continent of America or not. The probability is as I have already told you, that it is not, since Captain Munck thought there was a passage in this sea to the east, and to which he persuaded a number of persons of quality in Demmark, who had formed a company, to try and verify it.

I discover at the same time the errors of the person who has written dissertations upon the origin of the people of America, whom he makes out to have come from Greenland, ${ }^{3}$ and makes the first inhabitants of Greenland to have come from Norway. He proposed to make us believe this by a certain affinity which he points out between some Amcrican words which terminate in lan, and the land of the Germans, Lombards, and the Norwegians; and by the connection of manners, which, he says, there is between the Americans and Norwegians, whom he takes for the Germans of Tacitus.

You will judge, sir, by the continuance and the reasoning of my history, that this author crrs in every way. First, inasmuch as the Norwegians were not the first inhabitants of Greenland, as it appears from his narrations and the demonstrations I have given you of them; and inasmuch as that M. Tormins, who is very learned in the antiquities of the north, so far from connecting the origin of the people of America with the people of Greenland, thinks that the Skreglingres, the original inhabitants of Vestrebug in Greenland, came from America. Sccondly, he is mistaken, inasmuch as there is little or no probability that Greenland was part of the continent of America, and that the passage from the one to the other was not so well known nor so possible as is imagined. 'Thirdly, he is mistaken in that which I have shown you, that there is no affinity of language or man-

1 Georgii IIornii de Originihus Amerieanis Libri quatuor. Tide Lib. iii, cap. 6,6 , and 8 . 
ners between Girenland and Norway; and if, as he says, the Norwegians communieated their language and manners to the Americans, they must have gone elsewhere than by Greenland to get to America. I should here have a good opportunity of showing up other crrors of this dissertation, of making the anthor eat his own words, and of sending him to the land of visions and dreams; but as he now slecps his last slcep, wo will let him rest in quietness, and finish this history for our mutual satisfaction. I am ashamed of having interrupted the course of those learned and elegant compositions which you give us so liberally every day, by inflicting upon you the reading of a paper which has neither the quality nor value of your excellent works; and, however indulgent you may be towards me, I do not doubt but that you will have as much satisfaction in having finished the reading of this letter, as I have in having written it, and in telling you, sir, that I am

\section{Tour very lumble}

and afleetionate scrvint.

The Higue, June 18th, 16t(i. 



\section{Gods Power and Providence;}

Shewert,

\section{IN THE MIRAC V-}

lous Preservation and Deliverance of eight Englishmen, left by mischance in Green-land, Anno 1630, nine moneths and twelve dayes.

With a true Relation of all their miseries, their shifts and hardship they were put to, their food, \&c. such as neither Heathen nor Christian men ever before endured.

Writh a description of the chiefe Places and Raritics of that barren and cold country.

Frritlifully reported by Edward Pemilam, one of the eight men aforesaid.

As also with a Map of Green-land.

They that goe downe into the Sea in slips; that doe businesse in grent waters:

These see the rovkes of the Lord, and lits ronders in the Aerpip. I'sal, 107. 23. 24.

$$
\text { L O N D O N, }
$$

Prinled boy R. Y. for John Partridge, and are to he sold at the Signe of the sumne in l'unls church-yant. 1631. 

(5) 


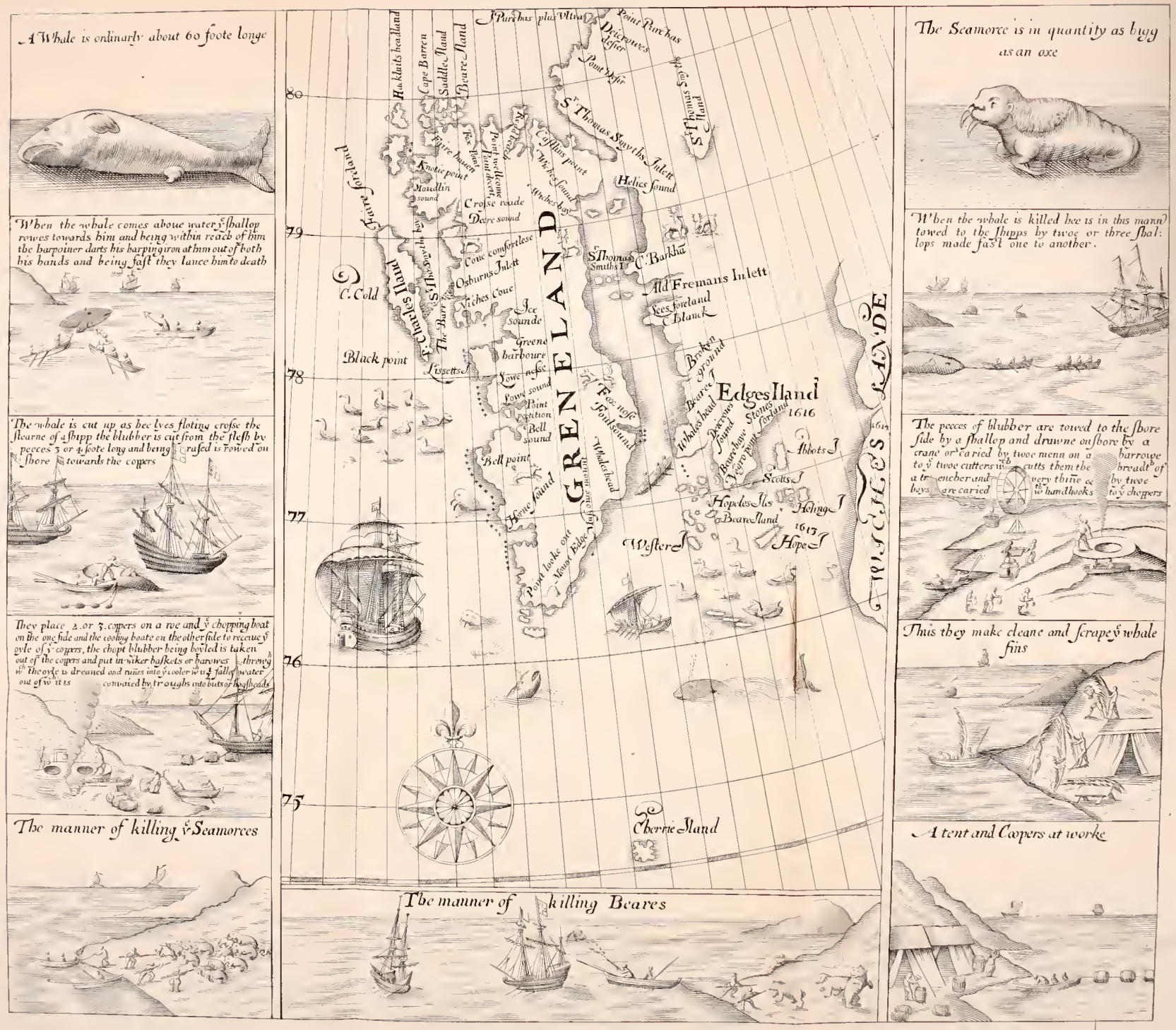




\section{RIGH'T WORSHIPFULA, SIR HUGH IIAM.}

mersly, Knight, Alderman of the Citie of London, Governour of the Worshipfull Company of the Muscovia Merchants:

And to the Worshipfull Mr. Alderman Frecman, Captaine William Goodler' and to all the rest of the Worshipfull Assistants and Adventurers in the said famous Company; Edward Pellham dedieateth loth this and his future Labours.

Right Worshipfull and most famous Mcrelıants:

THE hard adrenture my poore selfe and fellowes underwent in your Worships service, is a great deale plertsanter for others to reade, then it was for us to endure. How wer hard, wee huve now endured it: and if ever after ages shall speatie of it (as the world still doth of the Dutchmens hard Winter in Nora Zembla), thus much of the Toyage shall redound to your honours, - that it was done by your screants. This may also returne to our countreys good; that if the first inhabiting of a Countrey by a Prines Subiects (which is the hing of Spaines best title to his Indyes) doth take possession of it for their Soxeraigne: then is Green-land by a second right taken livery and Scisin of for his mejesties rse, his Subiects boing the first that ever did (and I believe the last that ever will) inhabite there. Many a rich returne may your Worships in generall, and the brave aulenturers in particular, veceive from this and other places: and may your servants be ceor hereafter wamed to tatic heale by our harmes. Goul send your worships long life, and much honour, and sufficient wealth, to maintaine both. This is the hearty prayer of your worships poove servant,

Enward Pelifham. 


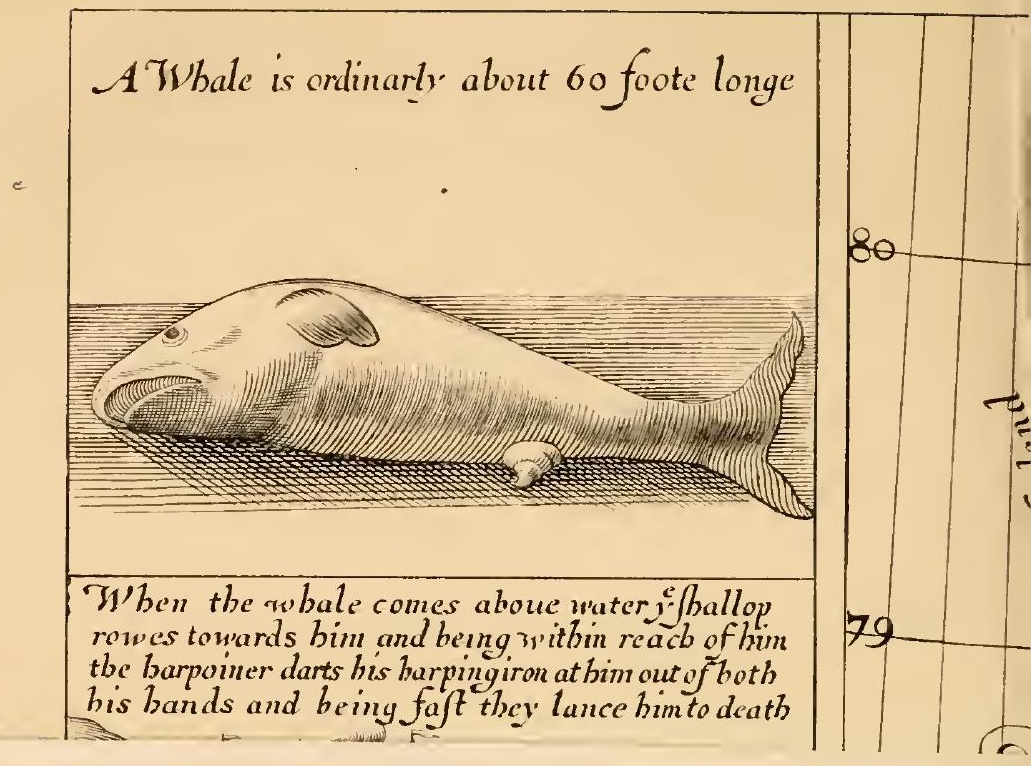




\section{RIGH'T WORSHIPFULA, SIR TITGH IAM.}

mersly, Knight, Alderman of the Citie of London,

Governour of the IVorshipfull Company

of the Muscoria Merchants :

\section{And to the Worshipfull Mr. Alderman Frecman,} Captaine William Goodler; and to all the rest of

the Worshipfull Assistants and Arrenturers in the said famous Company; Edward Pellham dedieateth loth this and his future Labours.

Right Worshipfull and most famous Merchants:

THE hard adventure my poore selfe and fellowes underuent in your Worships service, is a grcat deale plectsanter for others to reade, then it was for us to endure. How erer hurd, wee have now endured it; and if ever after ages shall speatic of it (as the world still doth of the Dutchmens havd Winter in Nora Zembla), thus much of the Toyage shall redound to your honours, - that it was done by your sereants. This may also returne to our countreys good; that if the first inhabiting of a Countrey by a Princes Subiects (which is the ring of Spaines best title to his Tudyes) (toth tulie possession of it for their Soreraigne: then is Green-land by a second right taken livery and Seisin of for his majesties rse, his Subiects being the first that ever did (and I bclieve the last that ever will) inhabite there. Many a rich returne may your Worships in generall, and the brave ad:enturers in particular, receive from this and other places: and may your serrants be over hereufter waned to take heede by our harmes. God send your worships long life, and much honour, and sufficient wealth, to maintaine both. This is the hearty prayer of your corships poore servent,

Fowari) Peigham. 
Courteous Reader: That God may have the onely glory of this our deliverance, give mee leave to looke backe unto that voyage which the Dutch-men made into Nova Zembla in the yeare 1596. In which place, they having beene (like oursclves) overtaken with the Winter, were there forced to stay it out as wee were. Which being an Action so famous all the world over, cncouraged mee both to publish this of ours, as also now to draw out some comparisons with them : that so our deliverance and Gods glory may appcare both the more gracious and the greater.

This Nova Zembla stands in the degree seventy-six North latitude; our wintering place is in seventy-seven Degrees and forty Minutes, that is, almost two degrees necrer the North Pole than they were, and so much therefore the colder. The Dutch were furnished with all things necessary both for life and health; had no want of any thing: Bread, Beere, and Wine they had good, and good store. Victuals they had Gods plenty, and apparell both for present clothing and for shift too; and all this they brought with them in their ship. We (God knowes) wanted all these. Bread, Beere, and Wine we had none. As for meate, our greatest and chicfest fecding was the Whale Frittars, and those mouldic too, the loathsomest meate in the world. For our Tenison 'twas hard to finde, but a great deale harder to get: and for our third sort of provision the Beares; 'twas a measuring cast which should be caten first, Wee or the Beares, when we first saw one ano- 
ther; and we pereived by them, that they had ats goou hopes to devoure us as wee to kill them. 'L'he Dutch kill'sl Licares, 'tis true; but it was for their skinnes, not for their Acsh. 'The Dutch had a Surgeon in their Companie; wee, none but the great Physician to take care and cure of us. 'They had the benefite of bathing and purging; wee, of neither. 'They had their Ship at hand to befriend them; wee had here perished, had not other Ships fetcht us off. They had Card and Compasse: wee, no dircetion. If the Dutch complained therefore of the extremity of the cold (as well they might), and that when in building their house, they (as Carpenter's use to doc) put the iron nayles into their mouthes, they there froze, and stucke so fast, that they brought off the skinne and forced blood: how cold, think you, were we, that were faine to maintaine two fires to keepe our very morter from freezing? 'The Dutch complain'd, that their walls were frozen two inches thicke on the inside for ill thcir fire; and if ours were not so, 'twas our pains and industry at first in building. The Dutchmens clothes froze upon their backes, and their shooes were like hornes upon their fecte; but that was their own ignorance; for they had Sea-coles enough with them, if they had knowne how to use then. If theire drinke and Sacke were so hard frozen into lumps of yce, that they were faine to cut it out: how much harder was it for us, that were forced to make hot Irons our best toasts to warme the snow withall for our mornings draughts! They used heated stones and billets to their fecte and bodics to warme them; which, though an hard shift, yet was it better than wee had any.

Lay now all these together: the distance of place, wee being many miles more into the cold than they; the want both of meate and elothes; and that the house wee lived in, we had but three dayes respite to build for nine moneths to come; and then may the world see that the Dutch had the better provisions, and wee the abler boclies. If, therefore, 
the Dutch-mens deliverance were worthily accounted a wonder, our's can amount to little lesse than a miracle. The greater therefore our deliverance, the greater must be Gods glory. And that's the authors purpose in publishing of it. (iod lieepe the readers from the like dangers. So prayes he that cndured what he here writes of.

Eiw. Pelhina.

THE NAMES OF THE MEN THUS STAYING IN GLEEN-LAXI, FOR NINE HONETHS AND TWELTE DAYES.

William Fakely, gumner; Edward Pellham, gunners mate, the atuthor of this relation; John Wise and Robert Goodfellow, sea-men; 'Thomas Ayers, whale-cutter' Henry Bett, cooper ; John Dawes and Richard Kellett, land-men. 
GODS POWER AND PROVIDENCE IN THE PRESERTA'TION OF EIGH'L MIEN IN GREEN-LAND, NINE MONETHS AND TWELVE DAYES.

But wee had the sentence of leath in our selves, that wee should not trust in our selves, but in God which raiseth the clead.

Who delivered us from so great a death, and doth deliver : in whom wee trust that he will yet deliver us. 2. Cor. i, ver. 9, 10.

Green-Land is a Country very farre Northward, sitnated in screnty-seven degrees and forty minutes, that is, within twelve degrees and twenty minutes of the very North Pole it selfe. The Land is wonderfull mountainous, the Mountaines all the year long full of yce and snow : the Plaines in part bare in Summer time. There growes neither tree nor hearbe in it, except Scurvy-grasse and Sorrell. The Sca is as barren as the Land, affording no fish but Whales, Sea-horses, Seales, and another small fish. And hither there is a yearely Flect of English sent. Wee eight men therefore being employed in the service of the Right Worshipfull Company of Huscowic merehants, in the good ship called the Salutation, of London, were bound for this Greenland aforesaid, to make a voyage upon Whales or Sea-horsc, for the advantage of the Micrehants and the good of the Common-wcalth. Wee set sayle from London the first day of May, 1630, and having a faire gale, wee quickly left the fertile bankes of Englands pleasant shoares behinde us. After which, setting 
our comely sayles to this supposed prosperous gale, and ranging through the boysterous billowes of the rugged Seas, by the helpe and gracious assistance of Almighty God, wee sifely arrived at our desired Port in Greenland, the elerenth of June following. Wherupon, having moored our ships and carryed our caske ashoare, wee, with all expedition, fell to the fitting up of our Shallops with all thinges necessarie for our intended voyage. Wee were in companie three Ships; all which were then appointed by the order of our Captaine, Captaine William Goodler, to stay at the Foreland, untill the fifteenth of July; with resolution, that if we could not by that time make a voyage accorcling to our expectation, then to send one ship to the Eastward, unto a fishing place some fourescore leagues from thence; whither, at the latter end of the yeare, the Whales use more frequently to resort. A second of the three ships was designed for Green-harbour (a place some fifteene leagues distant to the southward), there to trie her skill and fortune, if it were possible there to make a voyage. The third ship (which was the same wherein wee were) was appointed to stay at the Fore-land, untill the twentieth of Angust. But the captaine having made a great voyage at Bell Sownd, dispatches a Shallop towards our ship, with a commancl unto us to come to him at Bell Sownd aforesaid: his purpose being, both to have us take in some of his Trane-Oyle, as also, by joyning our forces together, to make the fleete so much the stronger for the defence of the merchants goods homeward bound, the Dunkirkers being very strong and rife at sea in those dayes. Upon the eighth day of August (thereupon), leaving the Forcland, wee directed oure course to the Southward, towards Green-harbour, there to take in twenty of our men, which had out of our ships company beene sent into the lesser ship for the furtherance of her royage.

But the winde being now contrary, our ship could no way lye our coursc. 'The fifteenth day, bcing ealme and cleare, 
and our ship now in the Offing, some foure leagues from Blacke-point and about fire from the Maydens pappes (which is a place famous, both for very good, and for great store of venison), our Master sent us eight men here named altogether in a shallop, for the hunting and killing of some Venison for the ships provision. Wee thus leaving the ship, and having taken a brace of dogs along with us, and furnisht our selves with a snap-hance, two lances, and a tinderboxe, wee directed our course towards the shoare, where in foure houres wee arrived, the weather being at that time faire and cleare, and crery way seasonable for the performance of our present intentions. That day we laid fourteene tall and nimble Deere along, and being very weary and throughly tyred (first with rowing, and now with hunting), wee fell to eate such victuals as wee had brought along, agreeing to take our rest for that night, and the next day to make an end of our hunting, and so fairely to returne to our ship againe. But the next day, as it pleased God, the weather falling out something thicke, and much yce in the Offing betwixt the shoare and the ship (by reason of a Southerly winde driving alongst the coast), our ship was forcel so farre to stand off into the sea to be cleare of the yce that wee had quite lost the sight of her; neither could wee assure our selves whether shee were inclosed in the drift yec or not; and the weather still growing thicker and thicker, we thought it our best course to hunt alongst the shoare, and so to goe for Green-harbour, there to stay abord the ship with the rest of our men vntill our own ship should come into the Port.

Coasting thus along towards Greene-harbour, wee kill'd eight Deere more; and so at last having well loaden our Shallop with T'enison, wee still kept on our course towards Green-harbour, where, arriving upon the seventecnth day, wee found (to our great wonderment) that the ship was departed thence, together with our twenty men aforesaid. 'That 
which increased our admiration was, for that wee knew they had not victuals sufficient aboard to serve them (by proportion) homewards bownd; which made vs againe to wonder what should be the reason of their so sudden departure.

Perceiving our selves thus frustrated of our expectation, and having now but bare three dayes (according to appointment) to the uttermost expiration of our limited time for our departure out of the Country, wee thought it our best course to make all possible speed to get to Bell Sownd unto our Captaine; fearing that a little delay might bring a great deale of danger. For the lightening therefore of our shallop, that she might make the better way through the waters, wee heaved our Venison overboard and east it all into the sea. Having thus forsaken Green-harbour with a longing desire to recover Bell Sownd (from thence distant some sixteene leagues to the Southward), that night wee got halfe way about the point of the Nesse, or point of land ealled Low-Nesse: but the darknesse or mistie fogge increasing so fast upon us, that it was impossible for us to get further; even there, betweene two rocks, we coved from the seventeenth day at night vntill the eighteenth day at noone. At which time, the weather being somewhat clearer (though very thicke still), wee left the Nesse behinde us, still desirous to recover Bell Sownd; but having never a Compasse to direct our course by, nor any of our company that was Pilot sufficient to know the land when he saw it, we were faine to grabble in the darke (as it were) like a blind man for his way, and so over-shot Bellpoint at least temne leagues to the Southward towards Horne Sownd.

Some of us in the meane time knowing that it was impossible to bee so long a rowing and sayling of eight leagues (for wee did both row and sayle), made enquiric How the harbour lay in? whereunto there was a ready answer made, 'That is, lay East in. Taking the matter therefore into our better consicleration, some of us judged, that it could not 
possibly be further to the Southward (our reason being, our observation of the lands rounding away and trenting towards the Eastrard) and resolved thereupon to row no further on that course for the finding of Bell Sownd. And though wee were againe perswaded by William Fakely, our Gunner (a proper Seaman, though no skilfull Mariner, who had been in the Country five or sixe times before, which none of our sca-men had beene), that it was further to the Southwards; yet we, trusting better to our own reasons than unto his perswasions, againe returned towards the Northward, which was our best and directest course indeed for the finding of Bell Sownd. Stcering of which course wee were now come within two miles of Bell Point, and the weather being faire and cleare, wee presently descryed the tops of the loftic mountaines.

William Fakely thereupon looking about him, presently cries out unto us, That wee were all this while upon a wrong Course; upon hearing of which words, some of our companie (yea the most) were perswaded to wend about the Boates head the second time, unto the Southwards; which one action was the maine and onely cause of our too late repentance, though for mine owne part (as it is well knowne), I never gave consent unto their counsell. And thus upon the fatall twentieth day August (which was the utmost day of our limited time for staying in the Country), wee againe returned the quite contrary way, namely, to the Southward. Thus utterly vneertaine when and where to finde the Sownd, a thousand sadde imaginations overtooke our perplexed minds, all of us assuredly knowing that a million of miseries would of necessitie ensue, if wee found not the ships whereby to save our passagc. In this distracted time of our thoughts, wee were now agnine the second time runne as farre to the Southward as at the first; and finding by all reason thereupon, how that there was no likelihood at all of finding any such place further to the 
Southward, we wended the shallop the second time unto the Northward. William Fakely herenpon, being unwilling to condescend unto our agreement, still perswaded us that That could not possibly bee our Course ; but we, not trusting any longer unto his unskilfull perswasions (though all in him was out of good will and strong conceit of his being in the rights), bent our Course to the Northward; and hee not consenting to steere any longer, I tooke the Oare out of his hand to steere the Boate withall. The weather all this while continued faire and cleare, and it pleased God at the very instant time to send the winde Easterly; which advantage we thankfully apprehending, presently set sayle. The winde increased fresh and large, and our Shallop swiftly running, we arrived the one and twentieth day at Bellpoint, were we found the wind right out of the Sownd at East Northeast so fiercely blowing, that we could not possibly row to Windwarde; but being forced to take in our sayle, we were faine to betake ourselves to our oares; by helpe of which wee recoverd some two miles within the shoare, where wce were constrained for that time to cove, or else to drive to Lee-wards.

Thus finding this to be the very place we had all this while sought for, (he now also agrecing thereunto,) we forthwith sought out and found an harbour for our Shallop; and having brought her thereunto, two of our men were presently dispatched over land unto the 'Tent at Bell Sownd, to see if the ships were still there, of which, by reason of the times being expired and the opportunitie of the present faire winde, wee were much afraid. The Tent being distant ten miles at the least from our Shallop, our men at their comming thither fincling the ships to be departed out of the Roade, and not being certaine whether or not they might be at Bottle Cove, (three leagues distant on the other sicte of the Sownd,) riding there under the Loome of the land; againe return unto us with this sadde newes. The storme of winde hitherto con- 
tinuing, about miclnight foll starke calme, whereupon we, unwilling to lose our first opportunity, departed towards Bottle Cove, betwixt hope and feare of finding the ships there; whither comming the two-and-twentieth, and finding the ships departed, we, having neither Pilot, Plat, nor Compasse for our directors to the Eastward, found ourselves (God he knoweth) to have little hope of any delivery out of that apparent danger. Our feares increased upon us, even whilst we consulted whether it were safest for us either to goe or stay. If goe, then thought wee upon the dangers in sayling, by reason of the much yee in the way, as also of the difficultie in finding the place when wee should come thereabouts. If we resolved still to remaine at Bell Sownd, then wee thought that no other thing could be looked for but a miserable and a pining death, seeing there appeared no possibility of inhabiting there, or to endure so long, so darksome, and so bitter a winter.

And thus were our thoughts at that time distracted, thus were our feares increased; nor were they causeless feares altogether. Well wee knew that neither Christian or Heathen people had ever before inhabited thoze desolate and untemperate Clymates. This also, to inerease our feares, had wee certainly heard, how that the merchants having in former times much desired, and that with proffer of great rewards for the hazarding of their lives, and of sufficient furniture and of provision of all things that might be thought necessary for such an undertaking, to any that would adventure to winter in those parts; conld never yet finde any so hardy as to expose their lives unto so hazardous an undertaking : yea, notwithstanding these proffers had beene made both unto Mariners of good experience and of noble resolutions, and also unto divers other bold spirits, yet had the action of wintering in those parts never by any beene hitherto undertaken. This also had we heard, how that the company of MIuscovie Merchants, having once procured the reprive of some male- 
factors that had heere at home beene convicted by Law for some haynous erimes committed; and that both with promisc of pardon for their faults, and with addition of rewards also, if so be they would undertake to remaine in Greenland but one whole yeare, and that every way provided for too, both of Clothes, Victuals, and all things else that might any way be needfull for their preservation. These poor wretches hearing of this large proffer, and fearing present execution at home, resolved to make tryall of the adventure.

The time of yeare being come, and the ships ready to depart, these condemned creatures are imbarked, who after a certain space there arriving, and taking a view of the desolateness of the place, they conceived such a horrour and inward feare in their hearts, as that they resolved rather to returne for England to make satisfaction with their lives for their former faults committed, than there to remaine, though with assured hope of gaining their pardon; Insomuch as the time of the yeare being come that the ships were to depart from these barren shoares, they made knowne their full intent unto the Captaine, who, being a pittifull and a mercifull Gentleman, would not by force constraine them to stay in that place, which was so contrary to their minds; but, having made his voyage by the time expired, hee againe imbarked and brought then over with him to England; where, through the intercession and meancs of the worshipfull companie of Muscovie merchants, they escaped that death which they had before beene condemned unto. The remembrance of these two former stories, as also of a third (more terrible than both the former, for that it was likely to be our own case), more miserably now affrighted us : and that was the lamentable and unmanly ends of nine good and able men, left in the same place heretofore by the sclfe same Master that now left us behinde; who all dyed miserably upon the place, being cruelly disfigured after their deaths by the savage beares and hungry foxes, which are not oncly the 
cirilest, but also the oncly inhabitants of that comfortlesse Countrey; the lamentable ends and miscarriage of which men, had bcene cnough indeed to have launted the spirits of the most noble resolution.

All these fearefull examples presenting themsclves before our eyes, at this place of Bottle Core aforesaid, made us, like amazed men, to stand looking one upon another, all of us, as it were, beholding in the present, the future calamities both of himselfe and of his fellowes. And thus, like men already metamorphosed into the rec of the Country, and already past both our sense and reason, stood wee with the eyes of pittie beholding one another.

Nor was it other mens examples and miscarriages and teares alone that made us amazed, but it was the consideration of our want of all necessary provision for the life of man, that already strooke us to the heart; For we were not only unprovided, both of clothes to keepe us warme and of foode to prevent the wrath of cruell famine, but vtterly destitute also wee were of a sufficient house wherein to slurowd and shelter our selves from the chilling cold. 'Thus for a space standing all mute and silent, weighing with our selves the miserie wee were already fallen into, and knowing rlelay in these extremities to be the mother of all dangers, we began to conceive hope eren out of the depth of despairc. Rowsing up our benummed senses therefore, wee now lay our heads and comnsels together, to bethinke our selves of the likeliest course for our preservation in that place; seeing that all hopes of gaining our passage into England were then quite frustrate. Shaking off therefore all childish and effeminate fearcs, it pleased God to give us hearts like men, to arme our selves with a resolution to doe our best for the resisting of that monster of Desperation. An agreement thereupon by a generall consent of the whole Companic we then entered into, to take the opportunitie of the next faire weather and 
goc for Green-harbour, to hunt and kill Venison for part of our winter provision.

Having thus agreed amongst ourselves, the fire and twenticth day of August, the weather and wind being both faire, wee direct our course towards Green-harbour, some sixteene leagues (as I before told you) distant from Bell Sownd; and the winde being fresh and faire, within the space of twelve houres we there arrived. Upon which place being now landed, the first thing we did was to make us a Tent with the sayle of our Shallop, pitcht up and spread upon our Oares; a sorry one (God knowes) though it were, yet under it we resolved to rest our selves that night, to refresh our bodies with such food as wee there had, and the next day to returne againe unto our hunting. The weather that night proving faire and cleare, wee made our slecpe the shorter (and, alas, what men conld sleepe in such an extremitie!); and fitting our selves and Shallop the best we might, to Coles Parke we went, a place some two leagues distant from us, and well knowne unto Thomas Ayers, that was one of our Companie, to be well stored with Venison. Comming a-shore at which place, though we found not so many Decre as we indeed expected, yet seven we killed the same day and foure Beares to boote, which wee also intended to eate.

But the weather beginning now to overcast, and not likely to continue good for hunting, wee that night returned againe unto Green-harbour, where, making us a Tent of our Sayle and Oares (as is before described), we fell to eate of such meate as God had sent us, and betooke our selves to our rest upon it. Having rested our selves a while, and now finding the weather to cleare up, we broke off our sleepe for that time, fitting our selves and two dogges againe to goe a hunting, leaving William Fakely and John Dawes behinde us in the Tent at Green-harbour as our Cookes (for the time), to dresse some meate that wee had for our refreshment at our return. 
Departing thus from the Tent, wee rowed towards Coles Parke; in the way whither, upon the side of a hill, by the sea side, wee espyed seven Deere fecding, whereupon presently a-shoare we went, and with our Dogs kill'd sixe of them; after which, the weather againe overeasting, wee thought it to little purpose to goe any further at that time, but resolved to hunt all along the side of that hill, and so at night to returne unto our Tent. Going thus along wee kill'd sixe Deere more, which wee had no sooner done but it began to blow and raine and to be very darke; whereupon wee hasted towards the 'Tent, there intending to refresh our selves with victuals and with rest for that night, and the next day to returne againe to our hunting. This purpose of ours was by the foule weather the next day hindered; for it fell so blacke, so cold, and so windy, that we found it no way fitting for our purpose. Lading therefore our owne Shallop with Beares and Venison, and another Shallop which we there found haled up and left by the Ships Companie, as every yeare they use to doe; lading this other shallop, I say, with the Graves of the Whales that had beene there boyled this present yeare (which wee there found in heapes flung upon the ground), wee, dividing our selves into two equal companies, that is to say, William Fakely, with one Sea-man and two Land-men with him, betaking themselves unto one Shallop, and Edward Pellham, with another Sea-man and two Land-men more with him, going into the other Shallop; wee all committed our selres unto the Sea, intending with the next faire weather to goe to Bell Sownd unto our Tent; which was the place wee set up our rest upon, to remaine at all the winter.

'Towards Bell Sownd therefore we went, with a purpose there to lay up our Store of what victuals wee had already gotten together; and with the next faire winde to come hither againe, to trie if it were possible for us there to provicle our selves of some more Venison for our Winter provision. 
Having thus laden both our Shallops, appointed our Companie, and all really now for our departure; wee were overtaken with the night, and there forced to stay upon the place. The next day was Sunday: wherefore wee thought it fit to sanctifie the Rest of it, and to stay our selves there untill Munday, and to make the best use wee could of that good day, taking the best course wee could for the serving of God Almighty ; although we had not so much as a Booke amongst us all, the whole time wee staid in that Country.

'The Sabbath day being shut up by the approaching night, wee betooke our selves to our Rest, sleeping untill the Sunne awakened us by his beginning to shew himsclfe upon the Munday morning. The day was no sooner peept, but up we got, fitting our selves and businesse for our cleparture. The weather was faire and clcare at the first, but after some foure houres rowing, the skie began so to overcast, and the winde to blow so hard, that we could not possibly get to Bell Sownd that night, but Coved halfe way untill the next morning, at which time we recovered Bottle Cove. To which place, when wee were once come, we found the winde (then at South-west) to blow so hard, that it was impossible for us to reach Bell Sownd, but were forced to stay at Bottle Cove for that night. Our Shallops we made fast one unto another with a Rope, fastening the head of the one unto the sterne of the other; and so casting our Grabnel or Anchor over-board, we left them ricling in the Cove.

But see now what a mischance, for the tryall of our patience, and for the making of us to relye more upon his providence than upon any outward meanes of our owne, God now suffered to befall us: We being now all a-shore, the South-west winde blew so hard and right into the Cove, that it made the Sea go high ; our Anchor also comming home at the same time, both our Shallops casting alongst the shoare, sunke presently in the Sea, wetting by this meanes our whole fruvision, the weather withall beating some of it out of the 
Boates, which wee found swimming up and downe the shoare. For, coming out of our 'Tent in the meane time, judge you what a sight this was unto us, to see, by mischance, the best part of our provision (the onely hope of our lives), to be in danger utterly to be lost (or at least spoyled with the Sea-water), for which we had taken such paines, and run such adventures in the getting. In this our miserie wee saw no way but one (and that a very desperate one), namely, to rume presently into the high-wrought Sea, getting by that meanes into our Shallops to save the remainder of our provisions, ready now to be washt quite away by the billowes. A Halser thereupon we got, which fastning unto our shallops, wee, with a Crabbe or Capstang, by maine force of hand, heaved them ont of the water upon the shoare. This done, all along the Sea side we goe, seeking there and taking up such of our prorisions as were swumme away from our Shallops. Having by this meanes gleaned up all that could be gotten together, we resolved from thenecforth to let our Boates lye upon the shoare, till such time as the weather should prove faire and better; and then to goe over unto Bell Sownd.

The third of September, the weather proving faire and good, we forthwith launched our Shallops into the water, and in them wee that day got into Bell Sownd. 'Thither, so soone as we were come, our first businesse was to take our provision out of our Shallops into the 'Tent; our next, to take a particular view of the place, and of the great Tent especially, as being the place of our habitation for the ensuing Winter. This, which we call the l'ent, was a kinde of house (indeed), built of Timber and Boards very substantially, and covered with Flemish Tyles, by the men of which nation it had, in the time of their trading thither, beene builded. Fourescore foot long it is, and in breadth fiftie. The use of it was for the Coopers, employed for the service of the Company, to worke, lordge, and live in, all the while 
they make caske for the putting up of the Trane Oyle. Our view being taken, we found the weather beginning to alter so strangely, and the nights and frosts so to grow upon us, that wee durst not adventure upon another hunting royage unto Green-harbour ; fearing the Sownd would be so frozen that wee should never be able to get backe to our Tent againe. By land it was (we knew) in vaine for us to thinke of returning, for the land is so mountainous that there is no travelling that way.

Things being at this passe with us, we bethought ourselves of building another smaller Tent with all expedition; the place must of necessity be within the greater Tent.

With our best wits, therefore, taking a view of the place, we resolved upon the South side. Taking downe another lesser Tent therefore (built for the Land-men hard by the other, wherein in time of yeare they lay whilest they made their Oylc) from thence we fetcht our materials. That Tent furnisht us with one hundred and fifty deale-boards, besides Posts or Stancheons and Rafters. From three Chimneys of the Furnaces wherein they used to boyle their Oyles, wee brought a thousand Bricks: therc also found wee three Hogshcads of very fine Lyme, of which stuffe wee also feteht another Hogshead from Bottle Cove, on the other side of the Sownd, some three leagues distant. Mingling this Lyme with the Sand of the Sea shore, we made very excellent good morter for the laying of our Bricks: falling to worke whereupon, the weather was so extreame cold, as that we were faine to make two fires to kecpe our morter from freezing. William Fakely and my selfe, undertaking the Masonrie, began to raise a wall of one bricke thicknesse, against the inner planks of the side of the Tent. Whilest we were laying of these Bricks, the rest of our Companie were otherwise employed every one of them: some in taking them downe, others in making of them cleane, and in bringing them in baskets into the 
Tent. Some in making morter, and hewing of boards to build the other side withall, and two othors all the while in flaying of our Tenison. And thus, having built the two outermost sides of the 'Tent with Bricks and Morter, and our Bricks now almost spent, wee were enfore't to build the other two sides with Boards; and that in this manner. First, we nayl'd our Deale boards on one side of the Post or Stancheon, to the thicknesse of one foot: and on the other side in like manner: and so filling up the hollow place betweene with sand, it became so light and warme, as not the least breath of ayre could possibly amoy us. Our Chimneys rent was into the greater Tent, being the breadth of one deale board and foure foot long. 'The length of this our Tent was twenty foot, and the breadth sixteene; the heighth teme; our seeling being Deale boards five or sixe times double, the middle of one joyning so elose to the shut of the other, that no winde could possibly get betweene. As for our doore, besides our making it so close as possibly it could shut; we lined it moreorer with a bed that we found lying there, which came over both the opening and the shutting of it. As for windowes, we made none at all, so that our light wee brought in through the greater Tent, by removing two or three tyles in the eares, which light came to us through the vent of our Chimney. Our next worke was, to set up foure Cabbins, billetting our selves two and two in a Cabbine. Our beds were the Deeres skinnes dryed, which we found to be extrardinary warme, and a very comfortable kinde of lodging to us in our distresse. Our next care then was for firing to dresse our meate withall, and for keeping away the cold. Examining, therefore, all the Shallops that had beene left a-shoare there by the Ships, we found seven of them very crazie, and not serviceable for the next yeare. Those wee made bold withall, brake them rp and carried them into our house, stowing them orer the beames in manner of a floore; in- 
tending also to stow the rest of our firing over them, so to make the outer 'Tent the warmer, and to keepe withall the snow from dryving through the tyles into the 'Tent, which snow would otherwisc have covered every thing, and have hindered us in comming at what wee wanted. When the weather was now grown colde, and the dayes short (or rather no dayes at all) wee made bold to stave some emptic Caske that were there left the yeare before, to the quantitie of a hundred tunne at least. We also made use of some planks and of two old Coolers wherein they cool'd their Oyle) and of whatsoever might well bee spared, without damnifying of the voyage the next yeare. Thus, having gotten together all the firing that wee could possibly make, cxcept we would make spoyle of the Shallops and Coolers that were there, which might easily have overthrowne the next yeares voyage, to the great hinderance of the Worshipfull Companie, whose servants wee being, were cvery way carefull of their profite. Comparing, therefore, the small quantitic of our wood, together with the coldnesse of the weather, and the length of time that there wee were likely to abide, we cast about to husband our stocke as thriftily as wee could, devising to trie a new conchision. Our tryall was this: When wee rak't up our firc at night, with a good quantitie of ashes and of embers, wee put into the midd'st of it a piece of Elmen wood-where, after it had laine sixtecne houres, we at our opening of it found great store of fire upon it, whereupon, wee made a common practice of it ever after. It never went out in eight monetlis together, or thereabouts.

Having thus provided both our house and firing; upon the twelfth of September, a small quantity of drift yce came driving to and fro in the Sownd. Early in the morning therefore wee arose, and looking every where abruad, we at list espyed two Sea-horses lying a-sleepe upon a piece of yee: presently thereupon, taking up an old Harping Iron 
that there Iay in the 'Tent, and fastening a Grapmell Roape unto it, ont launch't wee our Boate to row towards them. Comming something neere them, wee perceived them to be fast a-sleepe: which my selfe, then steering the Boate, first pereeiving, spake to the rowers to hold still their Oares, for feare of awaking them with the crashing of the yee; and I, skulling the Boate easily along, eame so neere at length unto them, that the Shallops even touch'd one of them. At which instant, William Fakely being ready with his Harping Iron, heav'd it so strongly into the old one, that hee quite disturbed her of her rest: after which, shee receiving five or sixe thrusts with our lanees, fell into a sounder sleepe of death. Thus having despach't the old one, the younger being loath to leave her damme, continued swimming so long about our Boate, that with our lances we kill'd her also. Haling them both after this into the Boate, we rowed a-shoare, flayed our Sea-horses, cut them in piees to roast and eate them. The nineteenth of the same moneth we saw other Sea-horses, sleeping also in like manner upon severall pieces of yee; but the weather being cold, they desired not to sleepe so much as before, and therefore could wee kill but one of them, of which one being right glad, we returned again into our 'Tent.

The nights at this time, and the cold weather increased so fast upon us, that wee were out of all hopes of getting any more foode before the next Spring; our onely hopes were to kill a Beare now and then, that might by ehance wander that way: The next day, therefore, taking an exacter survey of all our victuals, and finding our proportion too small by halfe, for our time and companie, we agreed among our selves to come to an Allowance, that is, to stint our selves to one reasonable meale a day, and to keepe Wednesdayes and Fridayes Fasting dayes, excepting from the Frittars or Graves of the Whale (a very loathsome meate) of which we allowed our selres sufficient to suffice our present hun- 
ger, and at this dyet we continued some three moneths or thereabouts.

Having by this time finished what ever we possibly could invent for our preservations in that desolate desert; our clothes and shooes also were so worne and torne (all to pieces almost) that wee must of necessity invent some new device for their reparations. Of Roape-yarne therefore, we made us thread, and of Whale-bones needles to sew our clothes withall. The nights were wax't very long, and by the tenth of October the cold so violent, that the Sca was frozen over, which had beene enough to have daunted the most assured resolutions. At which time, our businesse being over, and nothing now to exercisc our mindes upon, our heads began then to be tronbled with a thousand sorts of imaginations. 'Then had wee leisure (more than enough) to complaine our selves of our present and most miserable conditions. Then had wee time to bewaile our wives and children at home, and to imagine what newes our unfortunate miscarriages must needes be unto them. Then thought wee of our parents also, and what a cutting Corasive it would be to them, to heare of the untimely deaths of their children. Otherwhiles againe, wee revire our selres witl some comfort, that our friends might take, in hoping that it might please God to preserve us (even in this poore estate) untill the next yeare. Sometimes did we varie our griefes,-complaining one while of the cruelty of our Master, that would offer to leave us to these distresses; and then presently againe fell wee, not onely to excuse him, but to lament both him and his companic, fearing they had beene overtaken by the yce and miserably that way perished.

Thus tormented in mind with our doubts, our feares, and our griefes; and in our bodies, with hunger, cold and wants, that hideous monster of desperation began now to present his ugliest shape unto us; hee now pursued us, hee now laboured to seize upon us. Thus, finding our selves 
in a Labyrinth, as it were, of a perpetuall miscrie, wee thought it not best to give too much way unto our griefes; fearing they also would most of all have wrought upon oul weakenesse. On prayers we now redoubled unto the Almighty, for strength and patience in these our miseries, and the Lord gracionsly listned unto us, and granted these our petitions. By his assistance therefore, wee shooke off these thoughts and cheer'd up our selves againe, to use the best meanes for our preservations.

Now, therefore, began we thinke upon our Tenison and the preserving of that, and how to order our firing in this cold weather. For feare, thercfore, our firing should faile us at the end of the yeare, wee thought best to roast every day halfe a Decre and to stow it in hogsheads. Which wee, putting now in practice, wee forthwith filled three Hogsheads and an halfe, leaving so much raw as would serve to roast every Sabbath day a quarter, and so for Christmas day and the like.

This conclusion being made amongst us, then fell wee againe to bethinke us of our miseries, both passed and to come: and how (though if it pleased God to give us life) yet should we live as banished men, not onely from our friends but from all other companie. Then thought we of the pinching cold and of the pining hunger; these were our thoughts, this our discomrse to passe away the time withall. But as if all this miserie had beene too little, we presently found another increase of it: For, examining our provisions once more, wee found that all our Frittars of the Whale were almost spoyled with the wet that they had taken,after which, by lying so close together, they were now growne mouldie; And our Beare and Venison we perceived againe, not to amount to such a quantity as to allow us five meales a weeke,-whereupon, we were faine to shorten our stomacks of one meale more, - so, that for the space of three moneths after that, we for foure dayes in the wecke fed upon 
the unsavory and mouldie Frittars, and the other three, we feasted it with Beare and Venison. But, as if it were not cnough for us to want meate, we now began to want light also: all our meales proved suppers now, for little light could we see; even the glorious Sumne (as if unwilling to behold our miseries) masking his lovely facc from us, under the sable vaile of cole-blacke night. Thus, from the fourteenth of October till the third of February, we never saw the Sunne; nor did hee, all that time, ever so much as peepe above the Horizon. But the Moone we saw at all times, day and night (when the cloudes obscured her not) shining as bright as shee doth in England. The skie, 'tis true, is very much troubled with thicke and blacke weather all the Winter time, so that then we could not see the Noone, nor could discerne what point of the Compasse shee bore upon us. A kinde of daylight wee had indeed, which glimmer'd some eight houres a day unto us, in October time I meane; for from thence, unto the first of December, even that light was shortened tenne or twelve minuts a day constantly, so that, from the first of December till the twentieth, there appeared no light at all, but all was one continued night. All that wee could perceive was, that in a cleare scason now and then, there appeared a little glare of white, like some show of day towards the South, but no light at all. And this continued till the first of January, by which time wee might perceive the day a little to increase. All this darksome time, no certainety could wee have when it should be day or when night: onely my selfe out of mine owne little judgement, kept the observation of it thus. First, bearing in minde the number of the Epact, I made my addition by a day supposed (though not absolutely to bc known, by reason of the darknesse) by which I judged of the age of the Moone; and this gave me my rule of the passing of the time; so that, at the comming of the Ships into the Port, I told them the very day of the moneth, as directly as they themselves could tell mee. 
At the beginning of this darksome, irkesome time, wee sought some meanes of preserving light amongst us ; finding therefore a picce of Sheete-lead over a seame of one of the Coolers ; that we ript off and made threc Lamps of it, which maintaining with Oyle that wee found in the Coopers' 'Tent, and Roape-yarne serving us in steed of Candle-weekes, wee kept them continually burning. And this was a great comfort to us in our extremity. Thus did we our best to preserve our sclves; but all this could not sccure us, for wee, in our owne thoughts, accounted our selves but dead men; and that our Tent was then our darksome dungeon, and that we did but waite our day of tryall by our judge, to know whether wee should live or dye. Our extremities being so many, made us sometimes in impatient speeches to breake forth against the causers of our miseries; but then againe, our consciences telling us of our owne evill deservings, we tooke it either for a punishment upon us for our former wicked lives; or else for an example of God's mercie in our wonderfull deliverance. Humbling our selves therefore, under the mighty hand of God, wee cast downe our selves before him in prayer, two or three times a day, which course we constantly held all the time of our misery.

The new yeare now begun : as the dayes began to lengthen, so the cold began to strengthen; which cold came at last to that extremitie, as that it would raise blisters in our flesh, as if wee had beene burnt with fire: and if wee tonch't iron at any time, it would sticke to our fingers like Bird-lime. Sometimes, if we went but out a doores to fetch in a little water, the cold would nip us in such sort, that it made us as sore as if wee had beene beaten in some cruell manner. All the first part of the Winter we found water under the yee, that lay upon the Bache on the Sea-shoare. Which water issued out of an high Bay or Cliffe of yce, and ranne into the hollow of the Bache, there remaining with a thicke yce over it, which yee, wee at one certaine place daily digging 
through with pick-axes, tooke so much water as served for our drinking.

This continued with us untill the tenth of Januarie, and then were wee faine to make shift with snow-water, which we melted by putting hot Irons into it. And this was our drinke untill the twentieth of May following.

By the last of Januarie were the dayes growne to some seven or eight houres long, and then we again tooke another view of our victuals, which we now found to grow so short that it could no wayes last us above sixe weekes longer. And this bred a further feare of famine amongst us. But our recourse was in this, as in other our extremities, unto Almighty God, who had helps, wee knew, though we saw no hopes. And thus spent wee our time untill the third of Februarie. This proved a marvellous cold day; yet a faire and cleare one ; about the middle whereof all cloudes now quite dispersed, and nights sable curtaine drawne; Aurora, with her golden face, smiled once againe upon us, at her rising out of her bed; for now the glorious Sunne, with his glittering beames, began to guild the highest tops of the loftie mountaines. The brightnesse of the Sunne, and the whitenesse of the snow, both together was such, as that it was able to have revived even a dying spirit. But to make a new addition to our new joy, we might perceive two Beares (a shee one with her Cubbe) now comming towards our Tent; whereupon wee straight arming our selves with our lances, issued out of the Tent to await her comming. Shee soone cast her greedy eyes upon us, and with full hopes of devouring us shee made the more haste unto us; but with our hearty lances we gave her such a welcome as that shee fell downe, and biting the very snow for anger. Her Cubbe seeing this, by flight escaped us. The weather now was so cold, that longer wee were not able to stay abroad ; retiring therefore into our Tent, wee first warmed our selres, and then went out againe to draw the dead Beare in unto us. 
Wee flaied her, ent her into pieces of a stone weight or thereabouts, which served us for our dimners. And upon this Beare we fed some twenty dayes, for shee was very good flesh and better than our Tenison. 'This onely mischance wee had with her, that upon the eating of her Liver our very skinnes peeled off; for mine owne part, I being sicke before, by cating of that Liver, though I lost my skimne, yet recover'd I my health upon it. Shee being spent, either wce must secke some other meate, or else fall aboard with our roast Tenison in the Caske; which we were very loath to doe for feare of famishing, if so be that it should be thus spent before the Flecte came out of England. Amidst these our feares, it pleased God to send divers Beares unto our Tent, some fortie at least as we accounted. Of which number we kill'd seren: 'That is to say, the second of March one ; the fourth, another; and the tenth a wonderfull great Beare, sixe foote high at least. All which we flayed and roasted upon woodden spits (having no better kitehen-furniture than that, and a frying-pan we found in the Tent). They were as good sarory meate as any becfe could be. Having thus gotten good store of such foode, wee kepte not our selves now to such straight allowance as before; but eate frequently two or three meales a-day, which began to increase strength and abilitie of body in us.

By this, the cheerfull clayes so fast increased, that the several sorts of Fowles, which had all the Winter-time avoyded those quarters, began now againe to resort thither, unto their Summer-abiding. The sixteenth of March, one of our two Mastive Dogges went out of the Tent from us in the morning; but from that day to this he never more returned to us, nor could wee ever heare what was become of him. The Fowles that I before spake of, constantly use every Spring time to resort unto that Coast, being used to breede there most abundantly. Their foode is a certaine kinde of small fishes. Tearely upon the abundant comming of these Fowles, 
the Foxes, which had all this Winter kept their Burrows under the Rockes, began now to come abroad and seeke for their livings. For them wee set up three Trappes like Rattrappes, and bayted them with the skinnes of these Fowles, which wee had found upon the snow, they falling there in their flight from the hill whereupon they bred towards the Sea. For this Fowle, being about the bignesse of a Ducke, hath her legs placed so close unto her rumpe, as that when they alight once upon the land, they are very hardly (if ever) able to get up againe, by reason of the misplacing of their legs and the weight of their bodies; but being in the water, they raise themselves with their pinions well enough. After wee had made these Trappes, and set them apart one from another in the snow, we eaught fiftic Foxes in them; all which wee roasted, and found very good meate of them. 'Then tooke wee a Beares skinne, and laying the flesh side upward, wee made Springes of Whales bone, wherewith wee caught about sixty of those Fowles, about the bignesse of a pigeon.

'Thus continued wee untill the first of May, and the weather then growing warme, wee were now pretty able to goe abroad to secke for more provision. Every day therefore abroad wee went, but nothing could we encounter withall untill the 24 of May, when, espying a Bucke, wee thought to have kill'd him with our Dogge, but he was grown so fat and lazie that he could not pull downe the Deere. Seeking further out therefore, wee found abundance of Willocks egges (which is a Fowle about the bignesse of a Ducke), of which egges, though there were great store, yet wee being but two of us together, brought but thirty of them to the Tent that day, thinking the next day to fetch a thousand more of them; but the day proved so cold, with so much Easterly winde, that wee could not stirre out of our 'Tent.

Staying at home therefore on the 25 of May, we for that day omitted our ordinary custome. Our order of late (since 
the fuire weather') was, every day, or every second day, to goe up to the top of a mountaine, to spie if wee could discerne the water in the Sea; which, untill the day before, we had not seene. At which time, a storme of winde comming out of the Sea, brake the maine yce within the Sownd; after which, the winde comming Easterly, carried all the yce into the Sea and cleared the Sownd a great way, although not neare the shoare at first, seeing the cleare water came not neere our Tent by three miles at least.

This 25 of May therefore, wee all day staying in the Tent, there came two Ships of Hull into the Sownd; who, knowing that there had been men left there the yeare before, the Master (full of desire to know whether we were alive or dead) man'd out a Shallop from the Ship; with order to row as far up the Sownd as they could, and then to hale up their Shallop, and travell over-land upon the snow unto the Tent. These men, at their comming ashore, found the Shallop which we had haled from our 'Tent into the water, with a purpose to goe seeke some Sea-horses the next faire weather; the Shallop being then already fitted with all necessaries for that enterprize. This sight brought them into a quandary; and though this encounter made them hope, yet their admiration made them doubt that it was not possible for us still to remaine alive. Taking therefore our lanees ont of the Boate, towards the Tent they come; wee never so much as perceiving of them, for wee were all gathered together, now about to goe to prayers in the inner Tent, onely Thomas Ayers was not come in to us out of the greater Tent. The Hull men now comming neere our Tent, haled it with the usuall word of the Sea, erying "Hey:" he answered againe with "Ho," which sudden answer almost amazed them all, causing them to stand still halfe afraid at the matter. But we within hearing of them, joyfully came out of the Tent, all blacke as we were with the smoake, and with our elothes tattered with wearing. This uncouth sight made them fur- 
ther amazed at us; but, perceiving us to be the very men left there all the yeare, with joyfull hearts embracing us, and wee them againe, they came with us into our Tent. Comming thus in to us wee showed them the courtesie of the house, and gave them such victuals as we had; which was Venison roasted foure moneths before, and a Cuppe of cold water, which, for noveltie sake, they kindly accepted of us.

Then fell wee to aske them what newes? and of the state of the Land at home? and when the London Fleete would come? to all which they returned us the best answers they could. Agrecing then to leave the Tent, with then wee went to their Shallop, and so aboard the Ship, where we were welcomed after the heartiest and kindest English manner; and there we stayed our selves untill the comming of the London Fleete, which we much longed for, hoping by them to heare from our friends in England. Wee were told that they would be there the next day; but it was full three dayes before they came, which seemed to us as tedious a three dayes as any we had yet endured, so much we now desired to heare from our friends, our wives, and children.

The 28 of May the London Fleete eame into the Port to our great comfort. A-board the Admirall we went, unto the right noble Captaine William Goodler, who is worthy to be honoured by all Sea-men for his courtesie and bounty. This is the Gentleman that is every yeare chiefe Commander of this Fleete; and right worthy he is so to be, being a very wise man, and an expert Mariner as most be in England, none dispraised. Unto this Gentleman right welcome wc were, and joyfully by him received; hee giving order that we should have any thing that was in the Ship that might doe us good and increase our strength; of his owne charges giving us apparell also, to the value of twenty pounds worth. Thus, after fourteene dayes of refreshment, wee grew perfectly well all of us; whereupon the noble Captaine sent William Fakely and John Wyse (Mason's own Apprentice), 
and Thomas Aycrs, the Whale-Cutter, with Robert Goodfellow, unto Master Mason's Ship, according as themselves desired. But, thinking there to be as kindly welcomed as the lost Prodigall, these poore men, after their cnduring of so much misery, which through his meanes partly they had undergone,-no sooner came they aboard his ship, but he most unkindly call'd them Run-awayes, with other harsh and unchristian terms, farre enough from the civility of an honest man. Noble Captaine Goodlcr understanding all these passages, was right sorie for them, resolving to send for them againe, but that the weather proved so bad and uncertainc. I for mine owne part, remained with the Captaine still at Bottle Core, according to mine owne desire ; as for the rest of us that staied with him, hee preferred the Land-men to row in the Shallops for the killing of the Whales; frecing them thereby from their toylesome labour a-shoare, bettering their Meanes besides. And all these favours did this worthy Gentleman for us.

Thus were wee well contented now to stay there till the twentieth of August, hoping then to returne into our native Country; which day of departure bcing come, and we imbarked with joyfull hearts, we set sayle through the foaming Occan, and though cross'd sometimes with contrary windes homeward bound, yet our proper ships at last came safely to an Anchor in the River of Thames, to our great joy and comfort and the Merchants benefite. And thus by the blessing of God came wee all eight of us well home, safe and sound; where the Worshipfull Companic our Masters, the Muscovie Merchants, have since dealt wonderfully well by us. For all which most mercifull Preservation, and most wonderfully powerfull Deliverance, all honour, praise, and glory be unto the great God, the sole Author of it. He grant us to make the right use of it, Amen. 


\section{INDEX.}

Air, of the, 38

$\Lambda$ bbe, town in Greenland, 189

Ananavich, name given by the English to part of Greenland, 215

Animals of Greenland, 196, 197

Appel, (Nichael ), 12

Aretic coal-fish, $15 \mathrm{~s}$

Aretic fox, 80,145

Arutic skua, 66, 69, 156

Arctic tern, 73,157

Armenians, carried by tempest to Greenland, 181

Bear, anecdote of his cunning attempt to take a wallus, 144

Bear harbour or bay, 12, 25

Bears' flesh, feast of, and consequences, 144

Beautiful colour of the ice mountains in Greenland, 185

Beehive, hill at Spitzbergen so called, :2:2

Bell sound, 260, 261

Jeluga, northern, 101, 150

Bert-Iver, maitre d'hotel to the Bishol' of Greenland, 192

Birds, abundance of, 18 ; take refuge in the ship, 27; with toes or diviled feet, 57 ; with broad or web fect, 60

Pird's islands, 22

Bird's song island, 21

lishops of Greenland, list of, in the "Specimen Islandicum" of Angri mus Jonas, 189

Black Guillemot, 63, 154

Black pestilence of 1348,210

Bloserken, another name for Hindserkien, 185

Boats of the Greenlanders, 22:3; wonderful still in managing them, $2: 4$

Bottle-head, a small whale, 1(t), 14!)

Bremen, archbishop of, copy of the bull ennstituting him Metropolitan of all the North, 188

Brent goose, 151

Bintlifiort, 190

Birunnicli's Guillemot, t.5t
Burgermeister, or glaucous gull, 67, 150

Buts'sopf, or Places' Heal, 100, 149

Cape Farewell, 183, 184

Cathedral of Greenland, 189 ; its possessions, 191

Cliristian I. ling of Denmark, 212; Christian II., his cruelties, 213; Christian 11I., tries the passage to Greenland, and fails, $i b$.; Christian IV., takes great interest in the discovery of Greenland, 218

Christianity introduced into Greenland, 188

Christopher of Bavaria, 212

Christopherson, Claudius, a priest, composer of the Danish Chronicle, 181

Clifted Rock Island, 24

Climate of Greenland, 205

Colonrs of the sea, $: 31$

Common guillemot, 64,154

Common mackarel, 158

Common seal, 146

Cookery of Haarlem, 23

Crawfish (sea) without a tail, !l

Crow's foot, (plant) 48

Crustaceous fish, !) 1

Cuneate tailed gull, 156

Curious altars, ete. found by Captain Munck, 242

Danes, harbour of, at Spitzluergen, $\boldsymbol{\tau}$, $1: 21$

Danish chronicle, 18.3

1)ivis Straits, ib.

Deadman's island, 22

Deer or Muscle bay at Spitzbergen, 12 Jeer, ?0

Devils Huck, a large high mount at Spitzbergen, :2:2

Direr, great northern, 154; realtluroated, ib.

Diving parrot or puffin, 71, 154

Diurnes, first church in Greenland, 191 ; conntry belonging to it, 192

Dolulin, of the, 9!), 150

l) ragon fishl, 99, 15s 
Finler-ducks, 6i, 7:, 151

lilbe (the) to Spitzbergen, voyage from, 3

English harbon at Spitzbergen, $21,2 t$

Eric, the Tied, son of Torwald, Ist; discovers Greenland, 185 ; an island which he ealls Ericsun, 180; names the cuuntry Groenland, ib.; goes to leeland and induces many I celander's to settle in Greenland, 1 ; ; ; is angry with his son leeitie for bringing shipwrecked sailors to Grenland, $1>7$; is converted to Christianity, $185^{\circ}$

Eric, king of Denmark, assists Mag. nt1s, 190

Eric, ling of Pomerania, $21: 2$

Eric-fiorden, port of Eric, $1 \leqslant 6$

Ericsum, name given to the island found by Eric, $i b$.

Eyvetsfiord, 191

\section{Fais isle, $1 \pm$}

Farewell, (Cape) 183, 18t

Fertility of Greenland, contradictory accounts of, 105

Finn-fish, or razor lack, $5,13,132,149$

Fisb, crustaceous, 91

Fishes, (finned) 97

Foreland, Spitzbergen, $4,1 \pm, 21$

Forked tailed gnll, $15 \%$

Fos, royal residence so called, 191

Four-footed ereatures, 7!

Foxes, 20, :3t, 80, 145

Frederick I., :1:3; Frederick II., attempts the discovery of Greenland, 214

Fresh water at South harbour, Spitzlergen, 23

Frabisher, Martin, discovers Greenlaud in $157 \%, 214$; retmins the following year, 215; adventures with the natives, 210

Frost harclest in April and May, 34

Fulmer petrel, 75, 155

Funchebucler Port, Greenland, 19:

Garde, town built in the east of Greenland, 18 !)

Garnels or prawns, 92, 160

(ilaucous gull or burgomaster, 67,156 Goodler, Captain William, 25y

Great northern direr, 154

Green-harbour, 25 $\prec, 259$

Greenland shark, 103,158

Greenland, description of, 1-3; its bumnlaries, $i l$, conjectures respecting, ib. ; eleration aceording to $\mathrm{Cap}$ tain MIunck, ib. ; two elıunicles Icelandic and Danish, 184; said to be liscovered by some Armenians, $i b$.; discovered by the Norwegian Eric, son of Torwald, ib.; promontury called IInarf, 1s5; beantifi] appearance of the ice mom tains, $i b$; named by Eric Groenland, 186; Christianity introduced by Lejtre, son of Eric, 18x; arguments respecting the time of discovery of Gireenland, $i b$. ; dirided into east and west, 189 ; towns and monasterjes, ib.; bishops of, ib.; Norwegian viceroys, and Icelandic heroes, il. ; revolts against Maguns, king of Norway, 190; submits when Eric king of Denmark sends an ex. pedition against it, it.; places of interest described, ib. ; conjectures concerning the early inlalitants, 193 ; contralictory accounts of its fertility, 195; animals and virds, 196 ; fish, 197; Great abundance of horu, ib.; climate, 205; northern light, 2016; voyage from Norway to, 205 ; black pestilenee injures the commerce, 210 ; succession of misfortmnes, during which the country is lost sight of, $21 \%$; discorered by Frobisher, :14; description of the natives, etc., 215; Admiral Lindenan's royage, 2 I8; account of the juhabitauts, 2I8, 219; Lindenau's second royage, 2.21 ; Pichkardtsen's voyage, 222 ; nime natives taken to Denmark, 223; their boats, $i b$.; wonderful skill in managing them, 224 ; their unhappy fate, $2 \cdot 25,220 ;$ further description of the natives, 227 ; expedition of the merchants of Copenhagen, it.; trade with the natives, 28 ; the old and the new, 230 ; Captain IInuck's expedition, 237 ; described by Edward 1'elbam, $25 \%$

Groenland name given by Eric to Greenland, 1>0;

Guillemot, common, 64, 154; Bruunich's, ib. ; black, 63,151

Gull, emneate-tailed, 156; glancons, 67,156 ; forked-tailed, 156 ; listiwake, 65,150 ; jory, 62,156

Gundebinme Skeer, half way between Greenlard and Iceland, 20\%

Habits of the snail slime fislı, liff Hakon, Earl, called the Rich, Inis

Halfmoon bay, 25

llamlurglors, hallour of, at Spitz. lere. $11, \boldsymbol{7}, ?]$ 
Hans Lichtenberg, 7

Haresurt, gulf or strait, so named by Captain IIunck, $2 \pm 0$

Harp seal, $1 \pm 6$

Hart or deer, of the, 79

Hat slime-fish, 136

Havens of Spitzbergen, $\boldsymbol{\tau}, 18$

Hay, (the) or shark, 10:3, 158

Heigmingsen, Magnus, sent out by Frederick II., 211

Hellestad, royal house near the church of Eynetsfiord, 191

Henry, bishop of Garde, 189, 211

Herrieven, island, 191

Hilge-land, or Heligoland, 3, 14

Himmelradsfield, large rock, $19 \cdot$

Hindelopen, straights of, $10,11,25$

Hitland, 14, 28

Hooded seal, 146

Horn in great abundance in Greenland, 197

Housse leek, 47

Huarf, name of promontory, 185

Hudson, his discoveries mentioned, 237

Hudson's Bay lemming, skeleton of, 147

Huidserken, name of promontory, 185

Ice, of the, 32 ; beantiful colour and forms of the, 36,37

Ice mountains, 18,20

Ice bird, 59

Tcelandic chronicle, 181

Icelandic heroes, their exploits recorded by Angrimus Jonas, 189

Interesting account of the poor Greenlanders brought to Denmark and most cruelly detained there, 229,220

Ivory gull, $6: 25$, 15

"Jonas in the Whale," the ship, 3

Jonas, Angrimus, in his "Specimen Islandicum," gives a list of the bishops of Greenland, 189 ; gives the names of the viceroys of Greenland and celebrates the Icelandic heroes, $i b$; mentions the peace in $1:(11,190$; quotation from him, 193; quoted again, :201

Jolın Maien, island, 3, 25

Kindelfiord, on the west coast of Greenland, 191 ; sea of, 193

King cider duck, 152; care of their young, $i l$.; want of gallantry at the cud of the season, 153
Kirmew, 61, 73, 157

Kittiwake gull, 65,157

Kolding, governor of, punished for his cruelty and avarice by the loss of the poor savage through whom he hoped to enrich himself, 220

Korskirke, ehurch so called, 19]

Kuck's haven, 15

Kutge-gehef or Kittiwake gull, 65

\section{Langen island, 191}

Leiffe, son of Eric, goes to Norway and becomes Christian, 187; takes back a priest to Greenland to instruct Eric and the people, $i b$.; is called Leifflenhepen the happy, $i b$; is blamed by his father for his charity to some shipwrecked sailors, $i b$.; prevails on his father and his followers to become Christians, 188

Lemming (Hudson's Bay), $1 \pm \gamma$

Leonin, a Spanish naturalist, his account of Spitzbergen, 233

Lepeler, ship from Hamburgh, 6

Lesser garnels or shrimps, 93

Leifde bay (Bay of Love), 25

Lindenau, Danish aumiral, goes to Greenland, 218; his second voyage, 221

Little auk or common rotche, 68,155

Louse of the whale, 93

Lumbs and other water fowl, 27

Lumb (the), or common guillemot, 64 , 158

Lunesfiord, 191

Mackarel, 97, 158

II agdalen, harbour of, at Spitzlergen, $7,14,21$

Magnus, king of Norway, 190

Mallemucke or Fulmar petrel, 75, 155

Mangelsen (George and Cornelius), 12

Margaret, quecu of Norway and Denmark, her severity to merchants for going to Greenland without leave, 211

May-fly (sea), 135

Medicinal herbs, 18

Hedusa, immense numbers of, 170

Merchants of Copenhagen, their expedition to Greenland, $22 \%$; trade with the savages, 228

Mew, the, called kutge-gehef, 05

Mouse-ear, herb like, $5:$

Mountain duck, 61, 72,151

Mukla Jokel, name of Huidserken, 185

Munck, Jean, Danish captain, 183 ; his narrative, 237 ; he leaves the Sound, ib.; enters Hudson's Straits, 238; mceting with the savages, 239 ; names various places, 210,241 ; finds 
curious altars, etc., 212 ; sufferings of his people, 214; his own clanger, 215 ; lis infortunate end, $: 47$

Munckenes Vinterhaven, port of Innck's winter, ?41

Mascle liarbour, 10, 10, 21, 3]

Narwhal, the, 102, 14 ?

North bay or haven at Spitzbergen, 18, $2+$

Northern Light, 006

Northeru shark, 10:3, 15a

Nova \%embla, vorage of the Dutchmen in 1596,254 ; its position, ib.

Norwegians discover Greenland, 184

Olaus Truggerus, king of Norway, 187, 185

Opliidium Parii, 158

Ostrebug, dwelling built by Eric, 1<6; name afterwards given to the east of Greenland, 189

Pellham, Edward, his departure from London, $25 \%$; sent from the slip with seven men in a shallop to get renison, 259; they lose the ship, ib.; their wanderings and sufferings, $200-280$; arrival of two slips from Hull, 281 ; the London fleet arrives, and they are taken on board the Admiral, ?S?; return to England, 24:3

Periwinkle, plant like, 52

Pigeon or black guillemot, 53, 154

Pike whale, 149

Plants of Spitzbergen, 45

Plant with aloe-leaves, 46

Plover, ringed, 151

Polar bear, $80,1+3$

Pomarine skua, 156

Pope Gregory IV, his bull respecting the propagation of the faith in Greenland, $1 \times 8$

Prawns or garnels, 92, 160

Ptarmigan, 151

Puffin or Coulterneb, 71, 154

Purple sandpiper, 57

Qualms (sea), $13 \pm$

Rathsher or ivory gull, $6 \% 2,150$

Ravensfiord, port of, 18 (;

Razor-back, 149, 1:32

Razor-lill, 154

Piedpole, lesser, 150

Tied surmullet, 15 ?
Red-throated diver, 15t

liehenfelt ( Deerstield),, , $1: 2,: 1$

lieinteer, 79,147 ; their afliction for each other, 118

Reyatsen, island, 191

Richkaritsen, liarsten, his voyage to to Greenland, $: 2 \cdot 2 \cdot 3$

Ringed plover, 151

Roansen island, 1!)1

Rock plant, 51

Rose-like shaped slime-fisls, 137

Rotges or little auk, 6\%, 155

Rotz-fislies, 134

Rough or ringed seal, I45

Rumpesinfiord, 191

Sabine's gull, 157

Safe harbour at Spitzbergen, 19

St. Nicholas, church of, in the town of Garde, the cathedral of Greenland, 189 ; its possessions, 191

St. Olaus and St. Augustine, monastery dedicated to, 191

St. Thomas, monastery of, in Greenland, 189

Sandstafin roadstead, 185

Sandpiper, common, 151

Saw-fish or sword-fish, 102, 159

Schmeremburg, an old Dutel settlement, 22

Scurvy-grass, 49

Sea, of the, 26

Sea craw-fish without a tail, 91

Sea horses or mor'ses, $8,11,18,21$, s6, 146

Sea monsters, 209

Sea sickness, remedies for, 29

Seals, $4,5,83,145$; rough or ringed, 145; common, 146 ; harp, $i b$. ; hooded, ib.

Seanan, Cornelius, his ship crushed by the ice, 6

Shark, (the), 103, 158

Shrimps or lesser garuels, 93

Silver ore found in Greenland, 220

Singular effect of the first two stum. mer months in Spitzbergen, 38

Skajeford, the most eastern town in Greenland, 190

Skrelingres, said to lold possession of Vestrebug, 192; conjectures concenning, 103

Skua, (Pomarine), 156; (Arctic), 69, 156

Slime-fish like a cap, 128, 169 ; slimefish like a fountain, 139,169

Slime-fish (snail), 136, 166; (hat), 136; (rose-sliaped), 1:37

Snake-weed, $5 !$ 
Snefiel-rock of snow, 186

Snite, or purple sandpiper, 57,151

Snow and meteors, 40,44

Snow bird, or snow bunting, 58, 150

Sonth luarbour or bay, Spitzbergen, 12, $13,18,21,23$

South-west land, 25

Spiny lump-sucker, 158

Spitzhergen, first sight of, 4 ; arrival at, 7 ; home voyage from, 13; external face and appearance of, 16 ; havens, 18 ; birds, $i b$.; medicinal herbs, $i b$.; sea hor'ses, $i b$, ; ice mountains, $i b$., 20 ; animals, 20 ; hills and islands, $2: 2$; old Dntch settlement, 23 ; river at South Harbour, 23; islands, 21 , 25 ; the sea, 20 ; the ice, 32 ; the air, 38 ; the winds. 39 : the sun does not set from the 3rd of May till the 2nd of Augnst, 38,40 ; meteors and snow, 40 , 11 ; plants, 45 ; animals, 57 ; birds with toes or diviried feet, $i b$; broad, or web-footed birds, 60 ; four-footed creatures, 79 ; crustaceous fish, 91; finnell fish, 97; the whale, 105 ; fimn-fish, 132 ; rotz fishes and sea quahms, 13t; appendix to, 143; Leoniri's account of, 233

Star fish, 94,95

Stomias ferox, 158

Stone-crap, herb like, 50

Storluson Snorro, Icelandic eluronicles, 181

Storm, signs of, 28

Strawberry, herb like, 53

Strosnes church, formerly the metro. politan residence of the Bisliop of Greenland, 192

Strunt-jager, or dung-hunter, 69, 156

Sun (the) does not set from the 3rol of May till the 2nd of August, $3 \diamond, 40$ Sword-fish, 102
Talguestin, curious stone so called, 191 Torwald, a gentleman of Norway, father of Eric the Red, 18t

Train oil, preparation of, 1:30

Unctnous sucker, 158

Unfortunate pilot who went for gold and brought back sand, 22.29 , 229?

Unicorn or narwhal, 102, 149; discussion respecting, 198,205

Yalkandor, Eric, chancellor to Christian II, afterwards arehbishop of Dronthem, 213

Testrebug, dwelling built by Eric, 186; name afterwards given to the west of Greenland, $189^{\circ}$

Togelsanck, (bird's song) 12

Tormins, Dr., his opinion respecting the Skreglirigres, 193; argnment on the unicorn, 199; on the commerce of Greenland, 148t, 211; his evidence concerning the original inhabitants of Greenland, 248

Voyage from Norway to Greenland, 202

Walrus, or morse, $86,1 \pm 6$; adventure with a bear, 14t; aneclote of a mother and young one, 147

Warmth of the weather in July, 40

Weigate, or Weighatt, or straits of Hindelopen, 10, 11,25

Whales taken, $f, \tau, 8$; encounter with, 9 ; others caught, 10,11 ; deal, a defence for the ship against the ice, 34

Whale, of the, 105; how to catch the, 116; what they do with the dead, 125 ; common, 149 ; pike, $i b$.

White bears, $11,20,34,81), 143$

White fish, Northern Beluga, 101, 150

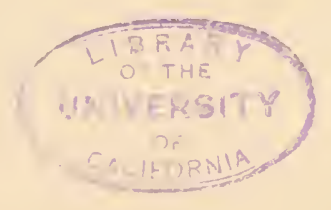

LONDOパ:

IICHARDS, 3\%, GREAT QUEEN STRFET. 




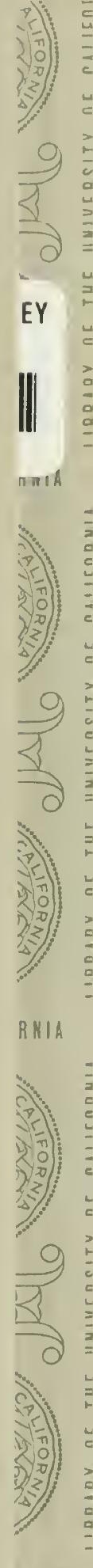




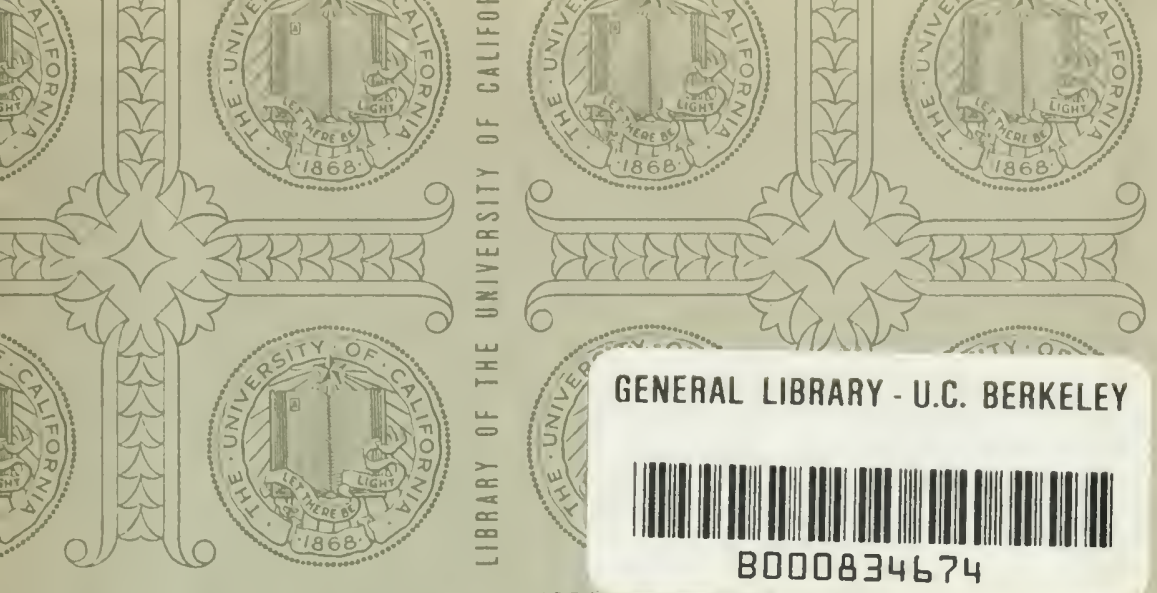

THE UNIVERSITY OF GALIFORNIA

LIBRAKI UP IHE UNITENJII UF UALITUMTIA

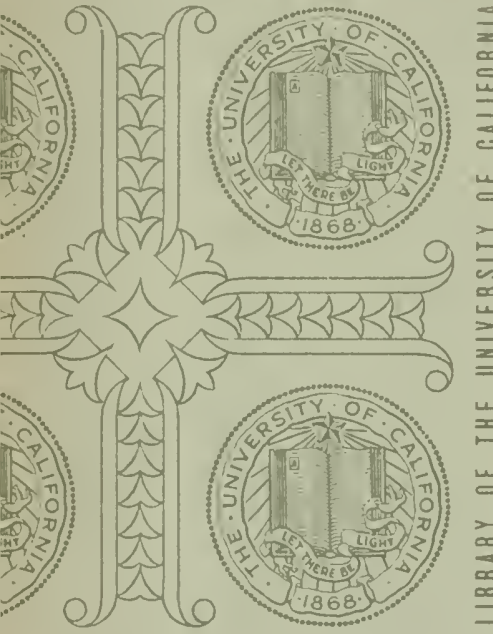

THE UNIVERSITY OF CALIFORHIA

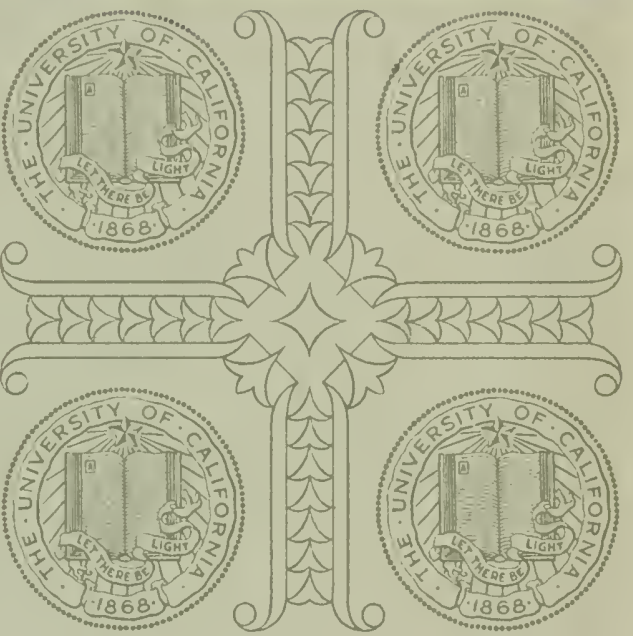

LIBRARY OF THE UNIVERSITY OF CALIFORNIA
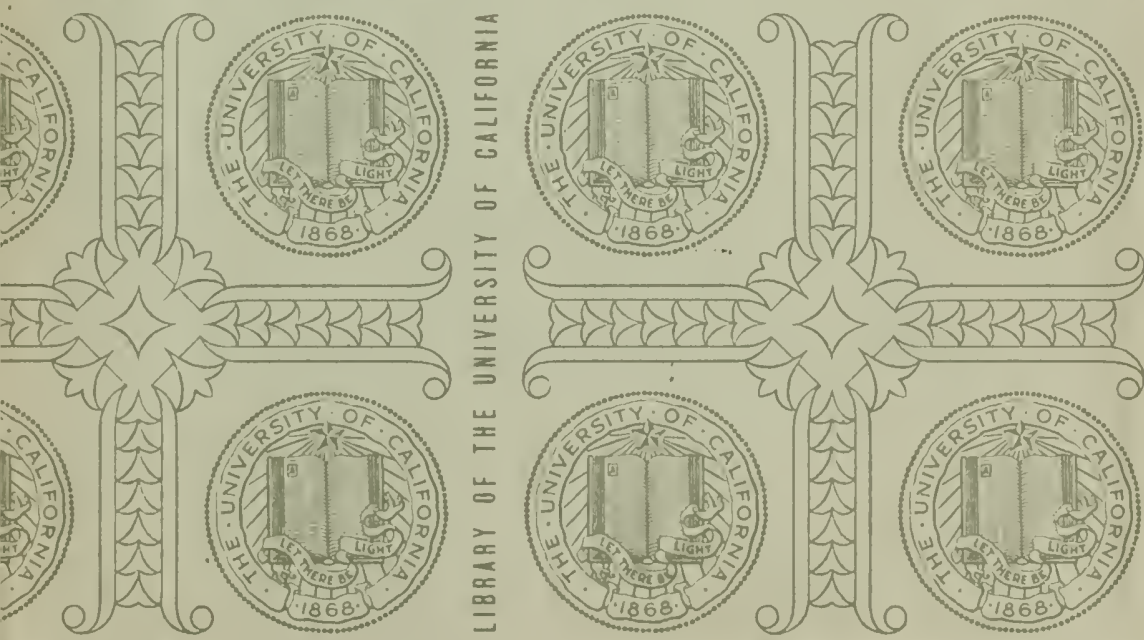
